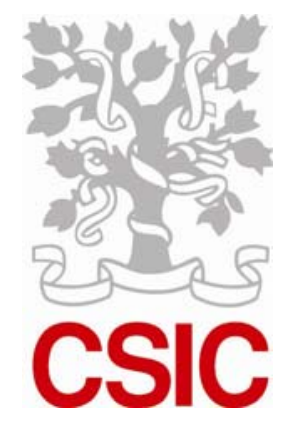

Análisis funcional y localización subcelular de las proteínas implicadas en el movimiento intra e intercelular del virus de las manchas necróticas del melón (MNSV)

\author{
Memoria presentada por \\ AINHOA GENOVÉS MARTÍNEZ \\ para optar al grado de \\ DOCTOR EN BIOQUÍMICA
}

Directores

Prof. VICENTE PALLÁS BENET

Doctor JOSÉ ANTONIO NAVARRO BOHIGUES

Valencia, 2008 

A Manolo 

A mis abuelos

A mis padres

A mi hermana 

$\mathcal{N}$ uestro trabajo no es averiguar cómo. $\mathbb{E}[$ cómo aparecerá a raíz de un compromiso y una creencia en el qué.

A todos aquellos que habéis participado en esta travesía. Gracias. 



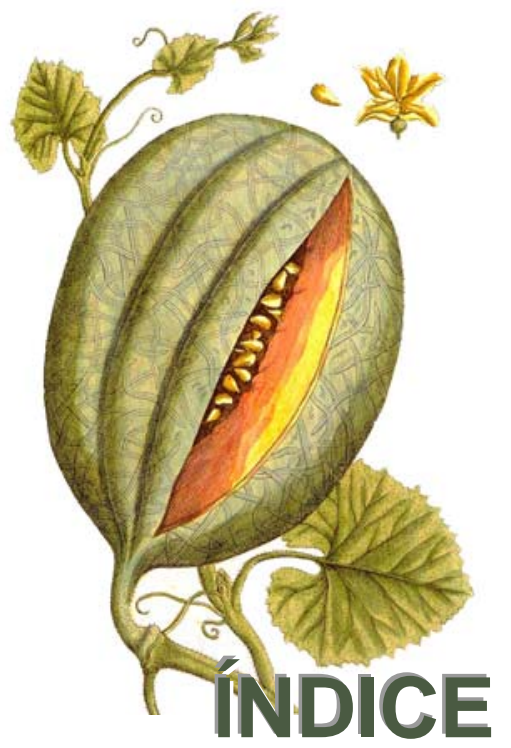


Abreviaturas................................................................................................................

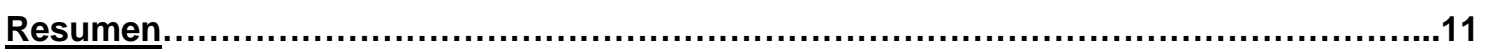

Introducción General...................................................................................................19

1. EL CONCEPTO DE VIRUS................................................................21

2. LOS VIRUS COMO PATÓGENOS DE PLANTAS: UNA VISIÓN GENERAL...............23

3. CLASIFICACIÓN TAXONÓMICA DE LOS VIRUS DE PLANTAS..........................27

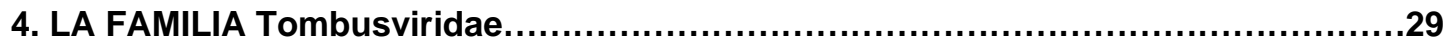

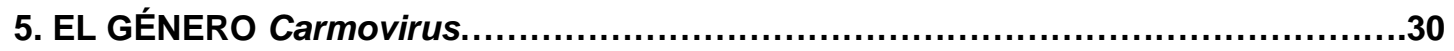

6. EL VIRUS DE LAS MANCHAS NECRÓTICAS DEL MELÓN, MNSV..........................34

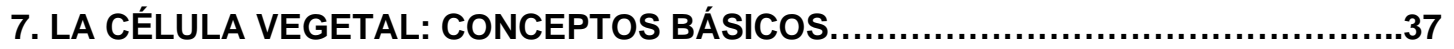

7.1 La pared celular

7.2 Los plasmodesmos

7.3 El Citoesqueleto

8. TRANSPORTE INTRACELULAR DE MACROMOLÉCULAS

8.1 Ruta secretora y endocítica: conceptos básicos

8.2 Mecanismos moleculares del transporte vesicular

8.2.1 El transporte anterógrado

8.2.2 El transporte retrógrado

8.2.3 Papel de las GTPasas en la fusión a membrana de vesículas.

8.2.4 Inhibición del transporte entre el retículo endoplasmático y el aparato de Golgi

8.2.5 Componentes de la matriz proteica del aparato de Golgi

9. INTERACCIONES RNA-PROTEÍNA..................................................51

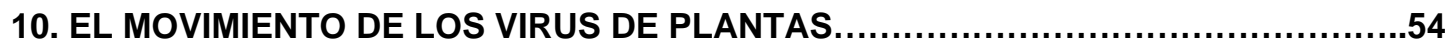

10.1 Las proteínas de movimiento

10.1.1 Estructura de las MPs virales

10.1.2 Localización subcelular de las MPs virales

10.2 Modelos de sistemas de transporte célula a célula

10.2.1 Movimiento viral basado en la formación de complejos

ribonucleoproteicos: el Virus del mosaico del tabaco (TMV)

10.2.2 Movimiento viral guiado por túbulos

10.2.3 Movimiento de virus con el bloque de tres genes (Triple Gene Block, TGB)

10.3 Transporte sistémico de virus de plantas

Justificación y Objetivos. 
Functional analysis of the five Melon necrotic spot virus genome-encoded proteins

Capítulo Il: .101

RNA-binding properties and membrane insertion of Melon necrotic spot virus (MNSV) double gene block movement proteins

Capítulo III:

A Carmovirus movement protein is associated to the Golgi peripheral membrane and its RNA-binding motif is required for the viral cell-to-cell movement

Capítulo IV: .151

Golgi-mediated traffic to plasmodesmata of a plant membrane-associated viral protein

Discusión General. 189

Conclusiones. .205

Bibliografía General. .209 


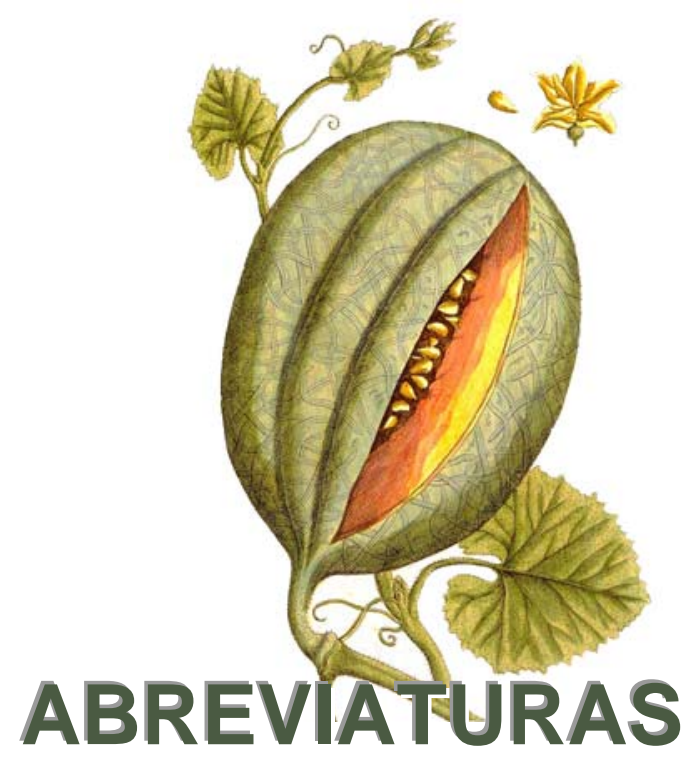


AG: aparato de Golgi

AMV: Alfalfa mosaic virus (Virus del mosaico de la alfalfa)

ARF: ADP-ribosylation factor (factor de ADP ribosilación)

ARL: ARF-like (proteína tipo ARF)

BiFC: bimolecular fluorescence complementation (complementación fluorescente bimolecular)

BMV: Brome mosaic virus (Virus del mosaico del bromo)

BS: bundle sheath (célula de la vaina)

BYMV: Bean yellow mosaic virus (Virus de mosaico amarillo de la judía)

BYV: Beet yellow virus (Virus del amarillamiento de la remolacha)

CarMV: Carnation mottle virus (Virus del moteado del clavel)

CC: companion cell (célula acompañante)

CCS: Carmoviruses consensus sequence (secuencia consenso de Carmovirus)

cDNA: complementary DNA (DNA complementario)

CDPK: calcium-dependent protein kinase (protein-kinasa dependiente de calcio)

ChFP: cherry fluorescent protein (proteína de fluorescencia del rojo cerezo)

CMV: Cucumber mosaic virus (Virus del mosaico del pepino)

COP: coat* protein (proteína del coatómero*)

CP: coat protein (proteína de cubierta o proteína de la cápsida)

CPMV: Cowpea mosaic virus (Virus del mosaico del chícharo)

Ct: carboxyl-terminal (extremo carboxilo)

DdRp: DNA dependent RNA polimerase (RNA polimerasa DNA dependiente)

DGB: double gene block (bloque de dos genes)

DGBp: doble gene block protein (proteína del bloque de dos genes)

DI RNA: defective interfering RNA (RNA defectivo de interferencia)

dpi: days post inoculation (días post inoculación)

dsRBD: double strand RNA binding domain (dominio de unión a RNA de doble cadena)

dsRNA: doble strand RNA (RNAs doble cadena)

EMSA: electrophoretic mobility shift assay (ensayo de retardo en la movilidad electroforética)

ER: endoplasmic reticulum (retículo endoplasmático) 
ERD2: ER retention defective 2 (defectivo de retención 2 en RE)

ERES: endoplasmic reticulum export sites (sitios de exportación del retículo endoplásmico)

ERGIC: endoplasmic reticulum-golgi intermediate compartment (compartimiento intermedio entre el retículo endoplasmático y el aparato de Golgi)

FS: frame shift (desplazamiento de pauta de lectura)

GA: Golgi apparatus (aparato de Golgi)

GAP: GTPase activating protein (proteína activadora de GTPasa)

GEF: guanine exhange factor (factor de intercambio de nucleótidos de guanina)

GFP: green fluorescent protein (proteína de fluorescencia verde)

GFLV: Grape fan leaf virus (Virus del entrenudo corto de la vid)

GRAB: GRIP-related ARF-binding (proteína de unión a ARF relacionada con el dominio GRIP)

GRASP: Golgi reassembly stacking protein (proteína de ensamblaje a golgi)

GRV: Groundnut rosette virus (Virus de la roseta del cacahuete)

HCPro: Helper component proteinase (componente ayudante-proteasa)

HCRSV: Hibiscus chlorotic ringspot virus (Virus de los anillos cloróticos del hibiscus)

HR: hypersensitive response (respuesta hipersensible)

ICTV: international committee on taxonomy of viruses (comité internacional de taxonomía de virus)

$\mathbf{K}_{\mathbf{d}}$ : apparent dissociation constant (constante aparente de disociación)

LBVaV: Lettuce big-vein associated virus (Virus asociado con las venas grandes de la lechuga)

MAP: microtubule associated protein (proteína asociada a microtúbulos)

MBP: maltose binding protein (proteína de unión a maltosa)

MCMV: Maize chlorotic mottle virus (Virus del mosaico clorótico del maíz)

ME: mesophyll cell (célula del mesófilo)

MNSV: Melon necrotic spot virus (Virus de las manchas necróticas del melón)

MP: movement protein (proteína de movimiento)

MPB2C: microtubule-associated plant protein 2C (proteína 2C asociada a microtúbulos)

mRFP: monomeric red fluorescent protein (proteína monomérica de fluorescencia roja)

mRNA: messenger RNA (RNA mensajero)

NLS: nuclear localization signal (señal de localización nuclear) 
NSF: N-ethylmaleimide-sensitive fusion protein (proteína de fusión sensible a N-etilmaleimida)

NSP: nuclear shuttle protein (proteína lanzadera nuclear)

Nt: amino-terminal (extremo amino)

ORF: open reading frame (pauta de lectura abierta)

PD: plasmodesmo

PFBV: Pelargonium flower break virus (Virus de la rotura de la flor del pelargonium)

PLRV: Potato leaf roll virus (Virus del enrollamiento de la hoja de la patata)

PME: pectin methyl esterase (pectina metilesterasa)

PoPit: potato proteinase inhibitor terminator (terminador del inhibidor de la proteasa de la patata)

PTGS: post-transciptional gene silencing (silenciamiento génico postranscripcional)

PVX: Potato virus X (Virus $X$ de la patata)

RCNMV: Red clover necrotic mosaic virus (Virus del mosaico necrótico del trébol rojo)

RdDp: RNA dependent DNA polimerase (DNA polimerasa RNA dependiente)

RdRp: RNA dependent RNA polimerase (RNA polimerasa RNA dependiente)

RE: retículo endoplasmático

RGP2: reversible glicosilated polipeptide 2 (polipéptido reversible glicosilado 2)

RISC: RNA-induced silencing complex (complejo de silenciamiento inducido por RNA)

RMN: resonancia magnética nuclear

RRM: RNA recognition motif (motivo de reconocimiento de RNA)

RT: read throught (lectura a través del codón de parada)

SAR: systemic acquired resistance (resistencia sistémica adquirida)

SE: sieve element (elementos cribosos)

SEL: size exclusion limit (límite de exclusión molecular)

sgRNA: subgenomic RNA (RNA subgenómico)

siRNA: small interfering RNA (RNA pequeño de interferencia)

SNAP: soluble NSF attachment protein (proteína soluble de acoplamiento a NSF)

SNARE: soluble N-ethylmaleimide sensitive factor attachment protein receptor (receptor proteínico de anclaje de factor soluble sensible a N-ethylmalemida).

ssRNA: single strand RNA (RNA de simple cadena) 
STtmd: sialyl transferase trasmembrane domain (dominio transmembrana de la sialyl transferasa)

TBSV: Tomato bushy stunt virus (Virus del enanismo ramificado del tomate)

TCV: Turnip crinkle virus (Virus del arrugamiento del nabo)

TEV: Tobacco etch virus (Virus del grabado del tabaco)

TGB: triple gene block (bloque de tres genes)

TGBp: triple gene block protein (proteína del bloque de tres genes)

TMD: transmembrane domain (dominio transmembrana)

TMV: Tobacco mosaic virus (Virus del mosaico del tabaco)

VIGS: virus-induced gene silencing (silenciamiento génico inducido por virus)

VP: vascular parenchyma (parénquima vascular)

VRC: virus-replication complex (complejo replicativo viral)

VTC: vesicule-tubular clusters (conjunto vesícula-tubular)

WCMV: White clover mosaic virus (Virus del mosaico del trébol blanco)

YFP: yellow fluorescent protein (proteína de fluorescencia amarilla) 


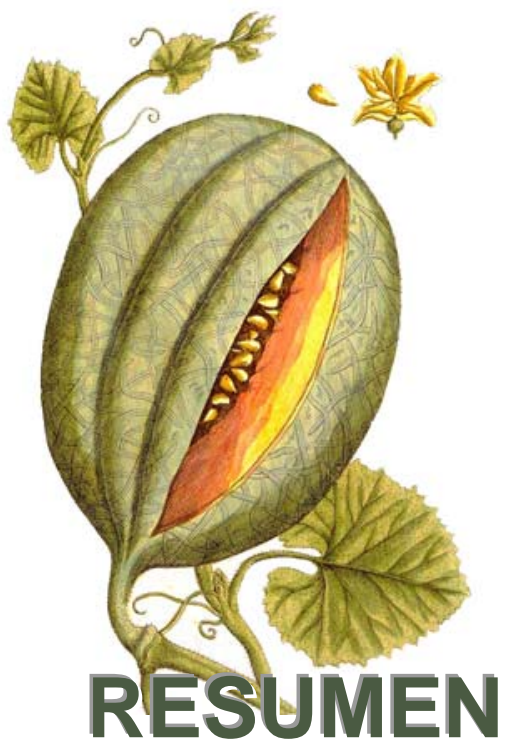


Los virus de plantas constituyen, en ocasiones, una seria amenaza para numerosos cultivos. A pesar de las numerosas investigaciones realizadas, existe un gran desconocimiento de las rutas y los mecanismos que operan en la invasión viral de los correspondientes huéspedes. El bloqueo en el movimiento viral constituye uno de los mecanismos de resistencia natural más frecuentes a los virus. El progreso en el conocimiento de estas etapas del ciclo viral puede llevar a estrategias antivirales. En el presente trabajo se ha pretendido caracterizar estructural y funcionalmente las 5 proteínas codificadas por el genoma del MNSV, haciendo especial hincapié en caracterizar los factores, tanto virales como celulares, que intervienen en el transporte intra e intercelular del virus.

Como paso previo y necesario, en el Capítulo 1 de la presente Tesis, se ha obtenido un clon infeccioso del MNSV, denominado pMNSV(Al), a partir del cual se pueden generar transcritos in vitro capaces de reproducir la misma sintomatología que el virus tras la inoculación mecánica sobre el huésped natural (melón). Este clon infeccioso constituye una herramienta molecular indispensable que ha permitido realizar un análisis funcional de los genes virales. Así, mediante técnicas de mutagénesis dirigida sobre el clon pMNSV(Al), se ha obtenido una colección de mutantes que impiden la expresión de cada una de las ORFs del genoma del virus. Además, las mismas modificaciones se han efectuado sobre un clon quimérico, pMNSV(Al)- $\Delta c p-G F P$, en el que se ha sustituido la ORF que codifica la CP viral por el gen testigo de la proteína de fluorescencia verde (GFP). Los resultados obtenidos ponen de manifiesto que las proteínas 29 y 89 estarían implicadas en la replicación del genoma. Por otro lado, la p7A y la p7B participarían en el movimiento célula a célula del virus. Por último, p42 ó CP, además de su papel estructural, es necesaria para la invasión sistémica del virus, siendo capaz de acentuar la sintomatología. Asimismo, ensayos de expresión transitoria de cada una de las ORFs del virus han puesto de manifiesto la capacidad de las proteínas 7B y CP para suprimir el silenciamiento génico de RNA, favoreciendo esta última el movimiento local del virus.

Una vez determinada la función de las proteínas codificadas por el MNSV se inició un estudio sobre la estrategia que utiliza este patógeno en su movimiento intra- e intercelular. En el Capítulo 2 se abordó un estudio bioquímico y estructural de las MPs del MNSV. Las proteínas de movimiento de los Carmovirus presentan una serie de características comunes a nivel de estructura secundaria que podrían ser la base de su similitud funcional. La p7A es una proteína rica en aminoácidos básicos e hidrofílicos que une preferentemente RNA de simple cadena de forma cooperativa y sin especificidad de secuencia aparente. Sin embargo, a diferencia de la p7 del Virus del moteado del clavel, en la que la función recae sobre el dominio central estructurado en $\alpha$-hélice, se ha demostrado que toda la secuencia de p7A está implicada en la unión, con una mayor participación de la región central en el proceso. Así, el péptido sintético correspondiente a la secuencia de la región central de p7A y estructurado en $\alpha$-hélice, es capaz de unir RNA aunque con una constante de disociación (Kd) significativamente mayor a la de la proteína entera $(9 \mathrm{mM}$ vs $25,7 \mu \mathrm{M})$. Por otro lado, la p7B se comporta como una proteína integral de membrana cuando es expresada en un sistema de 
transcripción/traducción in vitro en presencia de microsomas caninos derivados del RE. Posteriormente, se ensayó in vivo una colección de mutantes que afectan a diferentes propiedades estructurales de las MPs del MNSV. En el caso de la p7A, este estudio ha puesto de manifiesto que los residuos básicos, especialmente aquellos situados en la región central de la proteína, están directamente implicados en el movimiento local del virus, existiendo una relación directa entre la presencia o no de dichos residuos y la capacidad de unión a RNA de la p7A. Por otro lado, la disminución del perfil hidrofóbico de p7B, la desestructuración de la $\alpha$ hélice del fragmento transmembrana, así como la modificación tanto de los aminoácidos aromáticos como del balance de cargas a ambos lados de este dominio hidrofóbico, repercuten negativamente en el movimiento célula a célula del MNSV.

Por último, con la finalidad de obtener información sobre la ruta intracelular de este patógeno, se ha estudiado el patrón de localización subcelular de las MPs del MNSV. Para abordar este estudio se han obtenido construcciones recombinantes de la p7A y la p7B con las proteínas fluorescentes GFP o RFP. Éstas se ensayaron in vivo en presencia de marcadores de orgánulos celulares. El patrón de distribución subcelular de p7B muestra un dinamismo espacio-temporal que, dadas sus propiedades hidrofóbicas, coincide siempre con compartimentos membranosos de la célula. Inicialmente, la p7B se localiza en la red cortical del retículo endoplasmático (RE) y la membrana externa del núcleo. Posteriormente, la proteína forma parte de partículas móviles que se han identificado como dictiosomas del aparato de Golgi. Éstos se desplazan por el citoplasma de la célula mediante los microfilamentos de actina/miosina. Por último, la p7B se localiza en los plasmodesmos (PD). Por otro lado, aunque la p7A presenta características de proteína soluble, ésta forma agregados en el citoplasma de la célula, asimismo, también es capaz de unirse al aparato de Golgi y a los PD. La ausencia de otros factores virales no modifica el patrón de distribución subcelular de p7A, por lo que, dadas las propiedades de esta proteína, algún factor celular debe estar implicado en el mismo. Respecto la p7B, el tratamiento con Brefeldina A, un inhibidor de la ruta secretora, impide la salida de esta proteína al aparato de Golgi, quedando retenida en el RE y no llegando a los PD. Este resultado muestra que ésta podría ser la ruta utilizada por la misma para alcanzar la periferia de la célula durante una infección. Asimismo, la localización subcelular de diferentes formas mutantes de la p7B en las que se han modificado alguno de los determinantes de topología, hidrofobicidad e inserción a membrana de la misma, muestran una clara correlación entre movimiento célula a célula del MNSV y su patrón de distribución subcelular. De este modo, se ha establecido que cuando p7B no se localiza en los dictiosomas del aparato de Golgi el virus no es capaz de moverse célula a célula. Por último, el avance de la infección viral se ve drásticamente reducido en presencia de $\mathrm{BrA}$, sugiriendo la implicación de la ruta de secreción en el transporte intra e intercelular del virus. Los datos obtenidos en la presente Tesis han permitido la propuesta de un modelo de movimiento intracelular para los Carmovirus, en el que está implicada la ruta secretora a través del aparato de Golgi. Esta es la primera vez que este mecanismo se describe para un sistema de movimiento de virus de plantas. 
Els virus de plantes constitueixen, de vegades, una seria amenaça per a molts cultius. A pesar de les nombroses investigacions realitzades, existeix encara un gran desconeixement de les rutes i els mecanismes que operen en la invasió viral dels corresponents hostes. És important destacar que el bloqueig en el moviment viral constituïx un dels mecanismes de resistència natural més freqüents als virus. El progrés en el coneixement d'aquestes etapes del cicle viral pot dur a estratègies antivirals. En el present treball s'ha pretès caracteritzar estructural i funcionalment les 5 proteïnes codificades pel genoma del MNSV, fent especial èmfasi a caracteritzar els factors, tant virals com cel·lulars, que intervenen en el transport intra $\mathrm{i}$ intercelular del virus.

Com pas previ i necessari, en el Capítol 1 de la present Tesi, s'ha obtingut un clon infecciós del MNSV, denominat pMNSV(Al), a partir del qual es poden generar transcrits in vitro capaços de reproduir la mateixa sintomatologia que el virus després de la inoculació mecànica sobre l'hoste natural (meló). Aquest clon infecciós constituïx una eina molecular indispensable que ha permès realitzar una anàlisi funcional dels gens virals. Així, mitjançant tècniques de mutagénesi dirigida sobre el clon pMNSV(Al), s'ha obtingut una col-lecció de mutants que impedeixen l'expressió de cadascuna de les ORFs del genoma del virus. A més, les mateixes modificacions s'han efectuat sobre un clon quimèric, pMNSV(Al)- $\Delta c p-G F P$, en el qual s'ha substituït la ORF que codifica la $\mathrm{CP}$ viral pel gen testimoni de la proteïna de fluorescència verda (GFP). Els resultats obtinguts posen de manifest que les proteïnes 29 i 89 estarien implicades en la replicació del genoma. D'altra banda, la p7A i la p7B participarien en el moviment cèl.lula a cèl-lula del virus. Finalment, p42 o CP, a més del seu paper estructural, és necessària per a la invasió sistèmica del virus, sent capaç d'accentuar la sintomatologia. Així mateix, assajos d'expressió transitòria de cadascuna de les ORFs del virus han posat de manifest la capacitat de les proteïnes 7B i CP per a suprimir el silenciament gènic de RNA, afavorint aquesta última el moviment local del virus.

Una vegada determinades les funcions de cadascuna de les proteïnes codificades pel MNSV es va iniciar un estudi sobre l'estratègia que utilitza aquest patogen en el seu moviment intra- i intercelular. Com primera aproximació, en el Capítol 2 es va abordar un estudi bioquímic i estructural de les MPs del MNSV. Les proteïnes de moviment dels Carmovirus presenten una sèrie de característiques comunes a nivell d'estructura secundària que podrien ser la base de la seua similitud funcional. La p7A és una proteïna rica en aminoàcids bàsics i hidrofílics que uneix preferentment RNA de simple cadena de forma cooperativa i sense especificitat de seqüència aparent. No obstant això, a diferència de la p7 del virus del motejat del clavell, en la qual la funció recau sobre el domini central estructurat en $\alpha$-hèlix, s'ha demostrat que tota la seqüència de p7A està implicada en la unió, amb una major participació de la regió central en el procés. Així, el pèptid sintètic corresponent a la seqüència de la regió central de p7A i estructurat en $\alpha$-hèlix, és capaç d'unir RNA encara que amb una constant de dissociació (Kd) significativament major a la de la proteïna sencera (9mM vs 25,7 $\mu \mathrm{M})$. D'altra banda, la p7B es comporta com una proteïna integral de membrana quan és expressada en un sistema de 
transcripció/traducció in vitro en presència de microsomes canins derivats del RE. Posteriorment, es va assajar in vivo una col-lecció de mutants que afecten a diferents propietats estructurals de les MPs del MNSV. En el cas de la p7A, aquest estudi ha posat de manifest que els residus bàsics, especialment aquells situats en la regió central de la proteïna, estan directament implicats en el moviment local del virus, existint una relació directa entre la presència o no d'aquests residus i la capacitat d'unió a RNA de la p7A. D'altra banda, la disminució del perfil hidrofòbic de p7B, la desestructuració de la $\alpha$-hèlix del fragment transmembrana, així com la modificació tant dels aminoàcids aromàtics com del balanç de càrregues a banda i banda d'aquest domini hidrofòbic, repercuteixen negativament en el moviment cèl.lula a cèl/lula del MNSV.

Finalment, amb l'objectiu d'obtenir informació sobre la ruta intracel-lular d'aquest patogen, s'ha estudiat el patró de localització subcelular de les MPs del MNSV. Per a abordar aquest estudi s'han obtingut construccions recombinants de la p7A i la p7B amb les proteïnes fluorescents GFP o RFP. Aquestes es van assajar in vivo en plantes de $N$. benthamiana i en presència de marcadors d'orgànuls cel.lulars. El patró de distribució subcelular de p7B mostra un dinamisme espai-temporal que, donades les seves propietats hidrofòbiques, coincideix sempre amb compartiments membranosos de la cèl.lula. Inicialment, la p7B es localitza en la xarxa cortical del reticle endoplasmàtic (RE) i la membrana externa del nucli. Posteriorment, la proteïna forma part de partícules mòbils que s'han identificat com dictiosomes de l'aparell de Golgi. Aquests es desplacen pel citoplasma de la cèllula mitjançant els microfilaments d'actina/miosina. Finalment, la p7B es localitza en els plasmodesmes (PD). D'altra banda, encara que la p7A presenta característiques de proteïna soluble, aquesta forma agregats en el citoplasma de la cèl-lula, així mateix, també és capaç d'unir-se als dictiosomes de l'aparell de Golgi i als PD. L'absència d'altres factors virals no modifica el patró de distribució subcelular de p7A, pel que, donades les propietats d'aquesta proteïna, algun factor cel.lular ha d'estar implicat en el mateix. Respecte a la p7B, el tractament amb Brefeldina A, un inhibidor de la ruta secretora, impedeix la sortida d'aquesta proteïna a l'aparell de Golgi, quedant retinguda en el RE i no arribant als PD. Aquest resultat mostra que aquesta podria ser la ruta utilitzada per la mateixa per a arribar a la perifèria de la cèl.lula durant una infecció. Així mateix, la localització subcelular de diferents formes mutants de la p7B en les quals s'han modificat algun dels determinants de topologia, hidrofobicitat i inserció a membrana de la mateixa, mostren una clara correlació entre moviment cèl.lula a cèl.lula del MNSV i el seu patró de distribució subcelular. D'aquesta manera, s'ha establert que quan p7B no es localitza en els dictiosomes de l'aparell de Golgi el virus no és capaç de moure's cèl.lula a cèl.lula. Finalment, l'avanç de la infecció viral es veu dràsticament reduït en presència de BrA, suggerint la implicació de la ruta de secreció en el transport intra i intercelular del virus. Les dades obtingudes en la present Tesi han permès la proposta d'un model de moviment intracel.lular per als Carmovirus, en el qual està implicada la ruta secretora a través de l'aparell de Golgi. Aquesta és la primera vegada que aquest mecanisme es descriu per a un sistema de moviment de virus de plantes. 
Plant viruses constitute a serious threat for numerous crops. In spite of the numerous researches carried out, it exist still a great ignorance of the routes and the mechanisms that operate in the viral invasion of the corresponding host. It is important to emphasize that the blockade in the viral movement constitutes one of the more frequent mechanisms of natural resistance to virus. So, the progress in the knowledge of these stages of the viral cycle can lead to antiviral strategies. In the present work, it have been characterized the structure and the function of the 5 proteins codified by the MNSV genome, doing special support in characterizing the factors, both viral and cellular, that intervene in the transport intra and intercellular of the virus.

As previous and necessary step, in the Chapter 1 of the present Thesis, an infectious clone of the MNSV has been obtained, pMNSV, from which can be generated in vitro transcripts capable of reproducing the same symptoms that the virus after its mechanical inoculation on the natural host (melon). This infectious clone constitutes an indispensable molecular tool that has allowed to carrying a functional analysis of the viral genes. This way, by pMNSV clone oligonucleotide-directed mutagenesis, it has been obtained mutants that prevent the expression of each one of the virus genome ORFs. In addition, the same modifications have been effected on the recombinant clone, pMNSV- $\triangle \mathrm{cp}$-GFP, where the p42 ORF from the full-length clone has been replaced by the green fluorescence protein (GFP) reporter gene. The results revealed that the proteins 29 and 89 would be involved in the genome replication. On the other hand, the p7A and the p7B would take part in the virus cell to cell movement. Finally, the p42 ó CP, besides its structural role, is necessary for the virus systemic invasion, being capable of accentuating the symptoms. Likewise, the proteins 7B and CP, among all the MNSV encoded proteins, were able to delay the RNA silencing in transient expression assays. Finally, the p42 favoured the virus local movement.

Once determined the functions of each one of the proteins codified by the MNSV, this work was focus on elucidate the movement strategy followed by the virus. In the Chapter 2 , it was carried out a biochemical and structural study of the MNSV movement proteins. Carmovirus movement proteins present common characteristics in their secondary structure that might be the reason of its functional similarity. The 7A is hydrophilic protein that contains numerous basic residues which binds preferably simple chain RNA in a cooperative form and without apparent sequence specificity. Nevertheless, unlike the p7 of the Carnation mottle virus that has the functional motif constricted in the central $\alpha$-helix, there has been demonstrated that the whole sequence of p7A is involved in the RNA binding, with a major participation of the central region in the process. In this way, a synthetic peptide from the p7A $\alpha$-helix central region bound RNA with a dissociation constant $(\mathrm{Kd})$ significantly higher than the entire protein (9mM vs 25,7 $\mu \mathrm{M})$. On the other hand, in vitro the p7B behaved as an integral membrane protein when it was expressed in transcription/translation experiments in presence of ER-derived microsomal membranes. Later, it was assayed a collection of p7A and p7B mutants concerning different structural properties of this MNSV movement proteins. In case of the p7A, this study revealed 
that the basic residues, specially those placed in the central region of the protein, are directly involved in the local movement of the virus, existing a direct relationship between the presence or not of the above mentioned residues and the RNA binding ability. On the other hand, the decrease in the p7B hydrophobic profile, the unfolding of its transmembrane $\alpha$-helix, as well as changes on both the aromatic amino acids and the charge balance on both sides of its hydrophobic domain affect negatively in the MNSV cell to cell movement.

Finally, with the purpose of obtaining information about the intracelular route followed by the pathogen, there has been studied the subcellular location of the MNSV MPs. To approach these studies, there have been obtained recombinant constructs of both p7A and p7B with the fluorescent proteins GFP or RFP. These constructs have been transiently expressed in $N$. benthamiana plants in presence of cellular organelle markers. The subcellular distribution pattern of p7B shows dynamism in the time and in the space that, given its hydrophobic properties, coincides always with membranous compartments of the cell. Initially, p7B is located in the cortical network of the endoplasmic reticulum (ER) and the external membrane of the nucleus. Later, the protein forms part of mobile particles that have been identified like dictiosomes of the Golgi apparatus. These particles move within the cell cytoplasm by the actin/miosin microfilaments. Finally, the p7B is located in the cell plasmodesmata (PD). On the other hand, although the p7A presents characteristics of soluble protein, it forms attaches in the cell cytoplasm; likewise, it is capable of joining to the dictiosomes of the Golgi apparatus and to the PD. Moreover, the absence of other viral factors does not modify the subcellular distribution pattern of the p7A, by what, given the properties of this protein, some cellular factor must be involved in the same one. Concerning the p7B, the treatment with Brefeldin A, an inhibitor of the secretory route, prevents the exit of this protein to Golgi apparatus, remaining retained in the $\mathrm{RE}$ and not coming to the PD. This result shows that this one might be the route used by the same one to reach the periphery of the cell during an infection. Likewise, the subcellular location of different P7B mutants with the topology, the hydrophobity and the membrane insertion of the same one modified, show a clear correlation between the MNSV cell to cell movement of and the subcellular distribution of this constructs. Thus, it has been found that when p7B is not located in the dictiosomes of Golgi apparatus the virus is not capable of moving from cell to cell. Finally, the advance of the viral infection slows down in presence of BrA, suggesting the implication of the secretory route in the intra and intercellular transport of the virus. The information obtained in the present Thesis has allowed the formulation of a model for the intracelular movement of the Carmovirus, in which the secretory route across Golgi apparatus is directly involved, being the first time that this mechanism is described for the intracellular movement of a plant virus. 


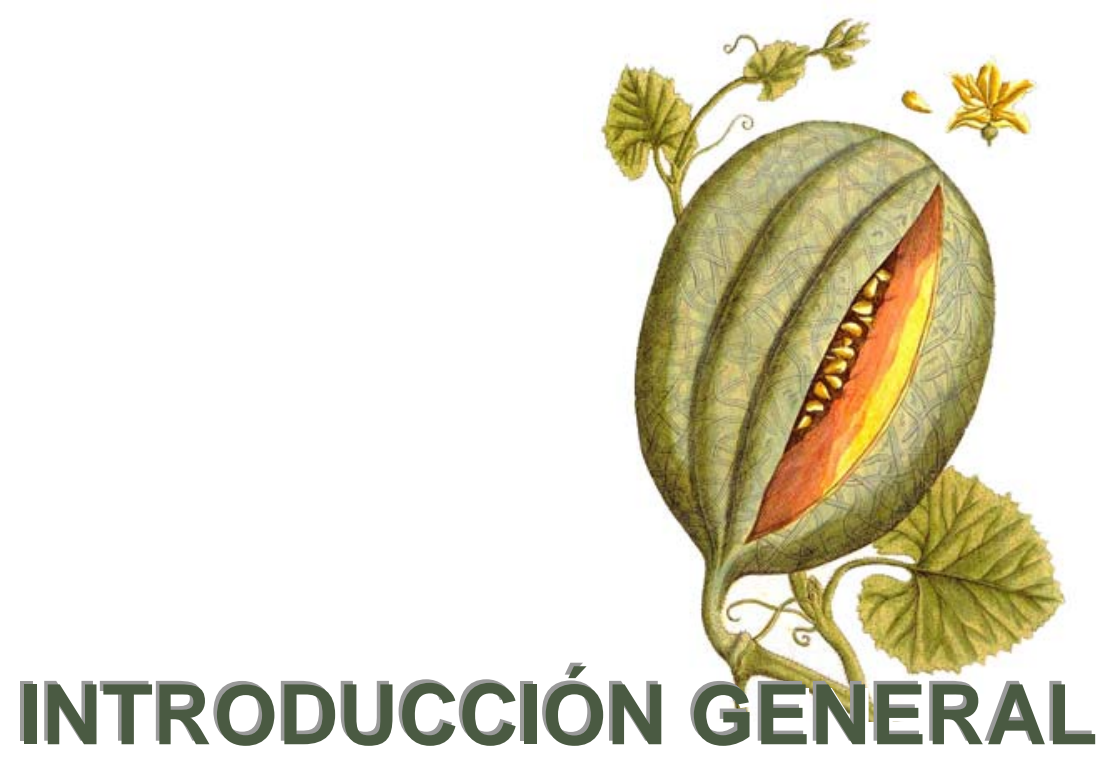




\section{EL CONCEPTO DE VIRUS}

La raíz etimológica de la palabra virus proviene del latín, "virus-i" y se utilizaba para definir un cierto tipo de veneno o jugo nocivo para la salud. En la actualidad, los virus se definen como agentes potencialmente patógenos de animales, plantas, hongos y bacterias, formados por un ácido nucleico acompañado o no de proteínas y que, a pesar de presentar un estadio extracelular, carecen de vida libre. Pese a su amplia variedad morfológica y estructural, su pequeño tamaño explica el tardío descubrimiento de los mismos.

En 1886, Adolf Mayer había centrado su investigación en una enfermedad de plantas de tabaco, que entonces se cultivaba al oeste de Wageningen (Holanda) a la que le denominó mosaico ("Mosaikkrankheit") por las decoloraciones que ocasionaba en sus hojas. A. Mayer demostró que se trataba de una enfermedad infecciosa ya que podía transmitirse de unas plantas a otras por simple frotación de un extracto de la planta afectada en las hojas de plantas sanas. Tras una serie de investigaciones A. Mayer concluyó que debía tratarse de una bacteria. Años más tarde, en 1892, el científico ruso Dimitri Ivanovsky reanudó la búsqueda del agente causal de esta enfermedad. Ivanovsky, tras homogenizar el tejido enfermo lo pasó por un filtro de porcelana capaz de retener bacterias $u$ otras entidades suficientemente grandes como para verse en los microscopios de aquella época. El filtrado no tenía ningún germen visible al microscopio pero seguía siendo capaz de ocasionar la enfermedad en plantas sanas. Por otro lado, en 1898 y de forma independiente, el botánico holandés Martinus Beijerinck recibió el encargo de A. Mayer de trabajar en esta enfermedad cuyo agente causal se resistía a ser determinado. M. Beijerinck, sin conocer los resultados de D. Ivanovsky, también observó que el jugo de la planta enferma era capaz de transmitir la enfermedad incluso después de pasar a traves de filtros de porcelana que son capaces de retener todas las bacterias aerobias posibles. Pero M. Beijerinck fue más allá y demostró que la infectividad del jugo extraído de una planta enferma permanecía constante durante diferentes pases seriales a plantas de tabaco, lo que descartaba la implicación de una toxina. Estos y otros experimentos le llevaron a concluir que el agente infeccioso de la enfermedad estaba constituido por lo que él denominó fluido vivo infeccioso "contagium vivum fluidum". Sin embargo, la naturaleza corpuscular de los virus fue propuesta por el bacteriólogo Friedrich Loeffler trabajando con una enfermedad del ganado conocida como fiebre aftosa en una investigación prácticamente simultánea a la de $\mathrm{M}$. Beijerinck (ver revisión en Pallás, 2007). En 1931, el bacteriólogo inglés William Elford logró determinar el tamaño del virus con el que trabajaba (100 nanometros de diámetro) utilizando membranas de colodión con orificios microscópicos de tamaños inferiores a los poros de los filtros de porcelana. Asimismo, en la década de los 30 con el desarrollo de la ultracentrifugación, el microscopio electrónico y la difracción de rayos $X$ se logró purificar y visualizar a estos agentes. Posteriormente y hasta nuestros días se han descubierto numerosos virus y se ha llevado a cabo un gran esfuerzo científico para determinar las características físicas, químicas y biológicas de los mismos. 
Los virus están compuestos por material genético (RNA o DNA) y, generalmente, una cubierta protectora de proteína que en el caso de virus de animales puede encontrarse combinada con componentes lipídicos o glúcidos del huésped que forman una o más envueltas adicionales. A la cubierta proteica externa se le llama cápsida y a las subunidades que la componen capsómeros. Normalmente, el genoma viral es una única molécula lineal de ácido nucleico de cadena simple o doble. Sin embargo, ciertos virus presentan su material genético segmentado. Al conjunto de material genético y cubierta se le conoce como virión.

Durante una infección, se sintetizan nuevos genomas virales que posteriormente se transportan a las células vecinas utilizando para ello tanto proteínas codificadas en el genoma viral como factores de la célula huésped. Los virus carecen del material necesario para la traducción de sus proteínas por lo que se pueden considerar como parásitos traduccionales de la célula.

La naturaleza del ácido nucleico viral determinará la secuencia de eventos que dará lugar a la multiplicación del virus y la síntesis de sus componentes fundamentales. En los virus de RNA de simple cadena de polaridad positiva, que constituyen la mayor parte de los virus de plantas, el RNA genómico es utilizado directamente como RNA mensajero de las proteínas virales que se encargarán de replicar el RNA viral y actuar sobre los procesos celulares. A su vez, la hebra complementaria servirá como molde de nuevas hebras positivas, que serán el material genético de la progenie viral. En el caso de virus RNA de simple cadena de polaridad negativa, la RNA polimerasa RNA dependiente (RNA dependent RNA polimerase, RdRp) encargada de copiar las cadenas positivas es encapsidada en el virión, mientras el RNA de polaridad positiva sintetizado servirá de mensajero de las proteínas virales y de molde de nuevas cadenas de RNA negativas, material genómico de la progenie. Para virus RNA de doble cadena, la RNA polimerasa RNA dependiente, constituyente de los viriones, será la encargada de sintetizar los RNA mensajeros de las proteínas virales y los RNAs de doble hebra de los viriones. Los retrovirus poseen dos copias de RNA monoténico, que sirven de molde para generar DNA viral doble hebra, que se integra en el genoma desde donde es tratado como el resto de genes celulares. La actividad enzimática que permite este proceso es una DNA polimerasa RNA dependiente (RNA dependent DNA polimerase, RdDp) codificada por el virus. Por último, los virus de DNA transcriben y traducen sus genes igual que los sistemas biológicos celulares, de esta forma se sintetiza el RNA mensajero (mRNA) a partir del DNA viral mediante el enzima RNA polimerasa DNA dependiente (DNA dependent RNA polimerase, DdRp) de la célula.

Dado el reducido tamaño de los genomas virales en relación con aquellos que presentan los organismos celulares, los virus usan multitud de estrategias para traducir varias proteínas a partir de la misma secuencia de nucleótidos: desplazamiento y solapamiento de pauta de lectura abierta (Open reading frame, ORF), codones de parada débiles, organización multipartita del genoma o síntesis de subgenómicos. La síntesis de proteínas virales ocurre a 
través de la maquinaria ribosomal del huésped y en el proceso de maduración, éstas pueden ser modificadas postraduccionalmente en el interior celular y/o ser procesadas por proteasas virales en el caso de sintetizarse como poliproteínas. Por último, el ciclo viral celular termina con el ensamblaje de los complejos virales apropiados (que incluyen o no a su forma virión) para su translocación a una nueva célula huésped.

La clasificación de los virus está siendo continuamente actualizada y viene regulada por el Comité Internacional de Taxonomía de Virus (International committee on taxonomy of viruses, ICTV). En la misma se hace referencia al material genético que contiene, a la envoltura del virión, cuando existe, o a las características biológicas, posición taxonómica de sus huéspedes, patología que producen, modo de transmisión, etc. Respecto a la nomenclatura, ésta suele incluir un nombre común derivado de los efectos patológicos y uno formal atendiendo a los taxones mediante los sufijos; Orden "-virales", Familia "-viridae", Género "-virus". Por su parte, respecto al taxón de Especie, existe una gran controversia en la asignación de los criterios para la clasificación de los virus en el mismo, y se ha determinado que no es suficiente un único criterio para ello.

\section{LOS VIRUS COMO PATÓGENOS DE PLANTAS: UNA VISIÓN GENERAL}

En la actualidad, se han descrito un gran número de virus que infectan plantas, llegando a ser ésta la segunda patología vegetal en importancia tras los hongos. Los virus causan importantes pérdidas medioambientales y económicas, lo que ha llevado al desarrollo de numerosas estrategias para su control. Por todo ello, el conocimiento de estos patógenos ha experimentado un considerable incremento en los últimos tiempos.

La sintomatología típica de los virus de plantas se caracteriza por la aparición de manchas en el tejido infectado. Éstas pueden ser cloróticas, provocadas por la pérdida de clorofila, o necróticas, producidas por la muerte de las células infectadas (Figura 1). Además, al margen de la sintomatología externa, existen toda una serie de síntomas microscópicos que provocan aberraciones anatómicas de las células y los tejidos infectados.
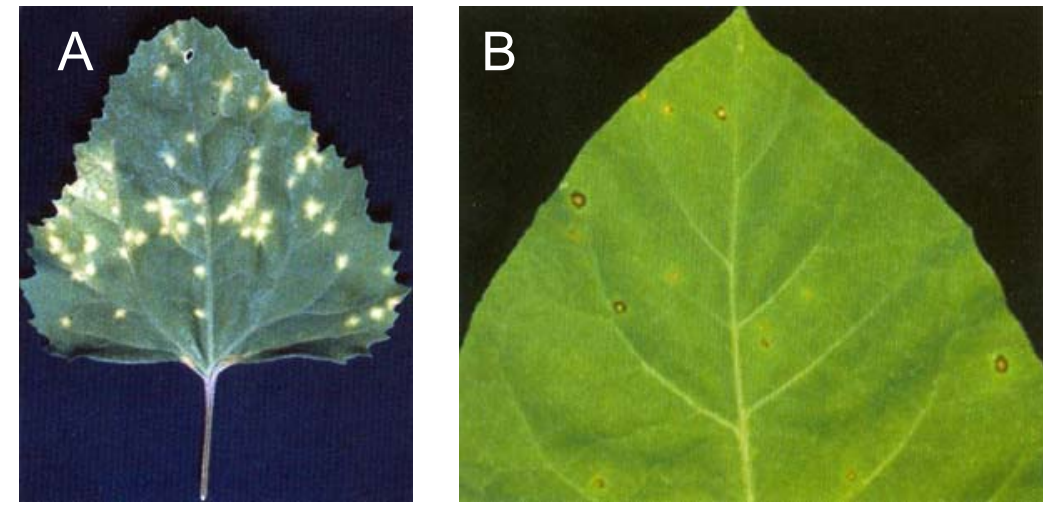

Figura 1. (A) Lesiones cloróticas en hoja de Chenopodium quinoa causadas por el Virus de mosaico amarillo de la judía (Bean yellow mosaic virus, BYMV). (B) Lesiones necróticas en hoja de Nicotiana tabacum provocadas por el Virus del mosaico del tabaco (Tobacco Mosaic Virus, TMV). 
Durante la infección viral se desencadenan numerosos procesos de interacción entre el virus y la planta cuyo conocimiento, todavía en ciernes, dará lugar al entendimiento de la patogénesis viral. Esta interacción planta-virus es extremadamente compleja y se ha estudiado en profundidad durante más de medio siglo. Sin embargo, se han dilucidado sólo parcialmente en los últimos años los mecanismos asociados con la acumulación y el movimiento viral en la planta, como asimismo la capacidad de éstas para defenderse de una infección viral. Con respecto a este último punto, se establece una interacción compatible entre la planta hospedadora y el virus (Hammond-Kosack y Jones, 1997) cuando el patógeno logra infectar prácticamente todos los tejidos de la planta, lo que puede ocurrir si las condiciones ambientales son favorables, si las defensas constitutivas de la planta son inadecuadas así como si la planta falla o tarda en detectar al patógeno provocando que las respuestas de defensa inducibles sean inefectivas. Por el contrario, si la planta reconoce rápidamente la partícula viral, se establece una interacción incompatible y desfavorable para el virus. En estas condiciones, no hay una infección generalizada y se da el fenómeno de resistencia conocido como respuesta hipersensible (Hypersensitive response, HR) que limita la replicación y el movimiento del virus, circunscribiéndolo al sitio inicial de la infección (Hammond-Kosack y Jones, 1997). A nivel molecular este mecanismo de defensa se basa en la teoría del gen por gen descrita por $\mathrm{H}$. Flor en 1971. Este modelo se define por la expresión de un gen de resistencia $(R)$ en la planta, el cual puede unir directa o indirectamente al producto del gen de avirulencia (avr) del patógeno (Bent, 1996; Ellis et al., 2000). En este contexto, las proteínas R actúan como receptor y las proteínas elicitoras avr como ligando (Ellis et al., 2000). De forma esquematizada, en una reacción incompatible, la formación del complejo receptor-ligando inicia una cascada de señales de transducción, que finalmente desencadenan la respuesta HR. La respuesta HR, también conocida como respuesta primaria, es una reacción local y se caracteriza por una muerte celular programada en el sitio de la infección (Heath, 2000; Shirasu y Shulze-Lefert, 2003). Además, durante el desarrollo de la reacción HR, se producen especies químicas oxidantes (Lamb y Dixon, 1997), se sintetiza callosa y lignina, se aumentan los niveles de ácido salicílico (Malamy et al., 1990) y se producen proteínas relacionadas con la patogénesis (Conejero et al., 1977; Semancik et al., 1977). Así, la respuesta secundaria es inducida por moléculas señal y finalmente se desencadena la resistencia sistémica adquirida (Systemic acquired resistance, SAR) inducida hormonalmente. Esta última se produce en puntos alejados del punto de entrada del patógeno y previene a la planta de infecciones secundarias (Hutcheson, 1998). De este modo, la respuesta de la planta ante el patógeno limita el movimiento a corta y larga distancia del mismo.

Por otro lado, en la década de los años 90, se describió un tipo de defensa que aparentemente difiere de la respuesta HR y que consiste en la degradación específica del RNA viral en el citoplasma de la célula infectada mediante lo que se conoce en plantas como silenciamiento génico postranscripcional (Post-transciptional gene silencing, PTGS) y que en este caso en concreto recibe el nombre de VIGS (Virus-induced gene silencing) (Baulcombe, 
2000; Carrington, 2000). Actualmente, existen crecientes evidencias de que la mayoría, si no todos, los virus de plantas han adoptado estrategias para escapar de esta capacidad defensiva de la planta y asegurarse la invasión sistémica. La forma más habitual, aunque no la única, de contrarrestar este mecanismo defensivo basado en el silenciamiento de RNA es la expresión de factores proteicos de origen viral que actúan suprimiendo el VIGS a diferentes niveles (revisado en Roth et al., 2004). Como ejemplos de estos supresores virales, se han descrito la proteína $2 \mathrm{~b}$ del Virus del mosaico del pepino (Cucumber mosaic virus, CMV), la p25 del Virus $X$ de la patata (Potato virus $X, \mathrm{PVX}$ ), la P1-HcPro del Virus del grabado del tabaco (Tobacco etch potyvirus, TEV) o la p19 del Virus del enanismo ramificado del tomate (Tomato bushy stunt virus, TBSV), entre otros. Estos ejemplos pertenecen a virus no relacionados filogenéticamente, lo que hace pensar que la capacidad de supresión del silenciamiento génico de RNA es una propiedad generalizada de los virus (revisado por Dunoyer y Voinnet, 2005; Qu y Morris, 2005; Brodersen y Voinnet, 2006).

En plantas se han descrito varias rutas de silenciamiento génico endógeno, aparte de las implicadas en defensa, que tienen un importante papel en la regulación transcripcional. Asimismo, la mecánica del proceso de silenciamiento de RNA puede dividirse en dos etapas: la iniciación y el mantenimiento. En la iniciación, las células huésped detectan la presencia anormal de RNAs doble hebra (doble strand RNA, dsRNA) cuyo origen es diverso (Hamilton y Baulcombe, 1999) y utilizan una ribonucleasa específica de dobles cadenas para digerir el dsRNA, generando pequeñas moléculas de RNAs de 21 a 26 nucleótidos conocidos como pequeños RNAs de interferencia (small interfering RNA, siRNA). La enzima encargada de esta actividad se llama Dicer (Bernstein et al., 2001). Se asume que las formas replicativas virales dan lugar a los dsRNA que disparan la activación de Dicer, aunque es probable que también actúen como diana regiones estructuradas de los genomas de RNA. Los siRNA generados por Dicer son reclutados por el complejo proteico RISC (RNA-induced silencing complex), lo que activa la digestión específica de secuencias homologas al RNA asociado. En la etapa de mantenimiento, el silenciamiento de RNA homólogos perdura en ausencia de la activación inicial por parte de las formas replicativas virales. Ello es debido a la amplificación de la señal, proceso en que una RdRp del huésped sintetiza nuevos dsRNA utilizando los siRNA como cebador y secuencias homologas del RNA celular como molde. Asimismo, la inducción local del silenciamiento en plantas genera señales que se transportarán al resto de tejidos de la planta provocando un silenciamiento prácticamente generalizado en todas las partes de la planta (revisado en Hamilton y Baulcombe, 1999; Mlotshwa et al., 2002).

Como se ha mencionado anteriormente, la mayoría de virus de plantas contienen genomas de RNA y frecuentemente de polaridad positiva. En este escenario, la actividad RdRp necesaria para la replicación es codificada por la información genética del virus. La purificación de RdRp de tejidos infectados por virus, tanto de animales como de plantas, así como el análisis de las correspondientes ORF ha llevado a determinar la existencia de motivos estructurales conservados e implicados en la función de las mismas como el triplete GDD 
(Hayes et al., 1994; Li et al., 1998; Dohi et al., 2002) o motivos definidos con actividad RNA helicasa (Kadare y Haenni, 1997) así como la capacidad de unión de estas proteínas a RNA (Huang et al., 2001; Choi et al., 2004). Por otro lado, elementos en cis del genoma controlan la replicación viral (Siegel et al., 1997; Nagy y Simon, 1998a; Nagy y Simon, 1998b; Panavas et al., 2002a; Panavas et al., 2002b). Por último, y de forma paralela, se ha descrito la implicación de las RdRps en procesos de defensa de la planta ante la infección viral (Xie et al., 2001; Yu et al., 2003; Petersen y Albrechtsen, 2005).

Después de evadir inicialmente los mecanismos de defensa del huésped y conseguir replicarse, el virus ha de moverse a otras partes de la planta. El movimiento del virus en la planta viene dirigido mayoritariamente por una o varias proteínas codificadas en el genoma, conocidas como proteínas de movimiento (Movement protein, MP). Estas proteínas, no presentan motivos de secuencia conservados entre familias virales: sin embargo, existe homología entre miembros de una misma familia. Las MPs virales pueden agruparse en cuanto a su número en: (i) uno, para miembros de la superfamilia de las $30 \mathrm{~K}$ que engloba a 18 géneros de virus de plantas tan característicos como Bromovirus, Alfamovirus o llarvirus, entre otros, y tiene como representante la MP del Virus del mosaico del tabaco (Tobacco mosaic virus, TMV); (ii) dos, en Carmovirus o Geminivirus (Doble gene block protein, DGBp); (iii) tres, para Potexvirus (Triple gene block protein, TGBp); (iv) cinco, para los Closterovirus. A pesar de la ausencia de similaridad de secuencia y número de las MPs virales, éstas presentan características funcionales comunes. La mayoría son capaces de unir a ácidos nucleicos, así como de interaccionar con los plasmodesmos celulares y en algunos casos, actuar aumentando el tamaño de exclusión de los mismos. Por último, una interesante característica de estas proteínas es la capacidad de beneficiarse del sistema celular de transporte de macromoléculas para desarrollar su función de movimiento.

Además de su papel estructural, se han descrito diversas funciones para las proteínas de cubierta virales (Coat protein, CP) o proteína de la cápsida. Las CPs están implicadas en muchos de los procesos del ciclo viral, entre los que podemos destacar la participación en: (i) replicación viral (Mahajan et al., 1996; Qut y Scholthof, 2001; Aparicio et al., 2003; Asurmendi et al., 2004; Bol, 2005; Malik et al., 2005); (ii) movimiento (Taliansky y Garcia-Arenal, 1995; Ryabov et al., 1999; Sareila et al., 2004; Omarov y Scholthof, 2005; Rao y Cooper, 2006); (iii) determinación del hospedador, sintomatología o modo de transmisión (Rao y Grantham, 1996; Wang y Simon, 1999; Soto et al., 2005); (iv) como supresor del silenciamiento génico postranscripcional (Brigneti et al., 1998; Qu y Morris, 2003; Yaegashi et al., 2007).

En la actualidad, existen varios frentes de investigación abiertos, estrechamente interconectados, entre los que cabe destacar; el control por el virus de los mecanismos que desencadenan el silenciamiento génico postranscripcional, la replicación y el movimiento viral. 


\section{CLASIFICACIÓN TAXONÓMICA DE LOS VIRUS DE PLANTAS}

Según los criterios de la ICTV (Fauquet et al., 2005), hasta la fecha, los virus de plantas se han clasificado en 20 familias y 88 géneros (Tabla 1).

\begin{tabular}{|c|c|c|}
\hline $\begin{array}{c}\text { FAMILIA } \\
(+) \text { RNA simple hebra } \\
\end{array}$ & GÉNERO & ESPECIE \\
\hline \multicolumn{3}{|l|}{ Potyviridae } \\
\hline & Potyvirus & Potato virus $Y$ \\
\hline & Rymovirus & Ryegrass mosaic virus \\
\hline & Macluravirus & Maclura mosaic virus \\
\hline & Tritimovirus & Wheat streak mosaic virus \\
\hline & Ipomovirus & Sweet potato mild mottle virus \\
\hline & Bymovirus & Barley yellow mosaic virus \\
\hline \multicolumn{3}{|l|}{ Sequiviridae } \\
\hline & Sequivirus & Parsnip yellow fleck virus \\
\hline & Waikavirus & Rice tungro spherical virus \\
\hline \multicolumn{3}{|l|}{ Comoviridae } \\
\hline & Comovirus & Cowpea mosaic virus \\
\hline & Fabavirus & Broad bean wilt virus 1 \\
\hline & Nepovirus & Tobacco ringspot virus \\
\hline \multicolumn{3}{|l|}{ Luteoviridae } \\
\hline & Luteovirus & Barley yellow drarf virus-PAV \\
\hline & Polerovirus & Potato leafroll virus \\
\hline & Enamovirus & Pea enation mosaic virus-1 \\
\hline \multicolumn{3}{|l|}{ Tymoviridae } \\
\hline & Tymovirus & Turnip yellow mosaic virus \\
\hline & Marafivirus & Maize rayado fino virus \\
\hline & Maculavirus & Grapevine fleck virus \\
\hline \multicolumn{3}{|l|}{ Tombusviridae } \\
\hline & Tombusvirus & Tomato busy stunt virus \\
\hline & Carmovirus & Carnation mottle virus \\
\hline & Necrovirus & Tobacco necrosis virus A \\
\hline & Machlomovirus & Maize chlorotic mottle virus \\
\hline & Dianthovirus & Carnation ringspot virus \\
\hline & Avenavirus & Oat chlorotic stunt virus \\
\hline & Aureusvirus & Photos latent virus \\
\hline & Panicovirus & Panicum mosaic virus \\
\hline \multicolumn{3}{|l|}{ Bromoviridae } \\
\hline & Bromovirus & Brome mosaic virus \\
\hline & Alfamovirus & Alfalfa mosaic virus \\
\hline & Cucumovirus & Cucumber mosaic virus \\
\hline & Ilarvirus & Tobacco streak virus \\
\hline & Oleavirus & Olive latent virus 2 \\
\hline \multicolumn{3}{|l|}{ Closteroviridae } \\
\hline & Closterovirus & Beet yellow virus \\
\hline & Crinivirus & Lettuce infectious yellows virus \\
\hline & Ampelovirus & Grapevine leafroll-associated virus 3 \\
\hline \multicolumn{3}{|l|}{ Flexiviridae } \\
\hline & Carlavirus & Carnation latent virus \\
\hline & Potexvirus & Potato virus $X$ \\
\hline & Capillovirus & Apple stem grooving virus \\
\hline & Trichovirus & Apple chlorotic leaf spot \\
\hline & Foveavirus & Apple stem pitting virus \\
\hline & Allexivirus & Shallot virus $X$ \\
\hline & Vitivirus & Grapevine virus A \\
\hline & Mandarivirus & Indian citrus ring spot virus \\
\hline \multicolumn{3}{|l|}{ Unassigned genera } \\
\hline & Tobamovirus & Tobacco mosaic virus \\
\hline & Tobravirus & Tobacco rattle virus \\
\hline & Hordeivirus & Barley stripe mosaic virus \\
\hline & Furovirus & Soil-borne wheat mosaic virus \\
\hline & Pomovirus & Potato mop-top virus \\
\hline & Pecluvirus & Peanut clump virus \\
\hline & Benyvirus & Beet necrotic yellow vein virus \\
\hline & Sobemovirus & Southern bean mosaic virus \\
\hline & Idaeovirus & Raspberry bushy dwarf virus \\
\hline & Ourmiavirus & Ourmia melon virus \\
\hline & Umbravirus & Carrot mottle virus \\
\hline & Sadwavirus & Satsuma dwarf virus \\
\hline & Cheravirus & Cherry rasp leaf virus \\
\hline
\end{tabular}




\begin{tabular}{|c|c|c|}
\hline \multicolumn{3}{|l|}{ (-) RNA simple hebra } \\
\hline Rhabdoviridae & & \\
\hline & Cytorhabdovirus & Lettuce necrotic yellows virus \\
\hline & Nucleorhabdovirus & Potato yellow dwarf virus \\
\hline Bunyaviridae & Tospovirus & Tomato spotted wilt virus \\
\hline \multirow{2}{*}{\multicolumn{3}{|c|}{ Unassigned genera }} \\
\hline & & Citrus psorosis virus \\
\hline & Tenuivirus & Rice stripe virus \\
\hline & Varicosavirus & Lettuce big-vein associated virus \\
\hline \multicolumn{3}{|l|}{ RNA doble hebra } \\
\hline \multicolumn{3}{|l|}{ Reoviridae } \\
\hline & Phytoreovirus & Wound tumor virus \\
\hline & Fijivirus & Fiji disease virus \\
\hline & Oryzavirus & Rice ragged stunt virus \\
\hline \multicolumn{3}{|l|}{ Partitiviridae } \\
\hline & Alphacryptovirus & White clover cryptic virus 1 \\
\hline & Betacryptovirus & White clover cryptic virus 2 \\
\hline Unassigned genera & Endornavirus & Vicia faba endornavirus \\
\hline \multicolumn{3}{|l|}{ DNA simple hebra } \\
\hline \multicolumn{3}{|l|}{$\overline{\text { Geminiviridae }}$} \\
\hline & Mastrevirus & Maize streak virus \\
\hline & Curtovirus & Beet curly top virus \\
\hline & Topocuvirus & Tomato pseudo-curly top virus \\
\hline & Begomovirus & Bean golden mosaic virus \\
\hline \multicolumn{3}{|l|}{ Nanoviridae } \\
\hline & Nanovirus & Subterranean clover stunt virus \\
\hline & Babuvirus & Banana bunchy top virus \\
\hline \multicolumn{3}{|l|}{ DNA doble hebra } \\
\hline \multicolumn{3}{|l|}{$\overline{\text { Caulimoviridae }}$} \\
\hline & Caulimovirus & Cauliflower mosaic virus \\
\hline & Soymovirus & Soybean chlorotic mottle virus \\
\hline & Cavemovirus & Cassava vein mosaic virus \\
\hline & Petuvirus & Petunia vein clearing virus \\
\hline & Badnavirus & Commelia yellow mottle virus \\
\hline & Tungrovirus & Rice tungro bacilliform virus \\
\hline \multicolumn{3}{|l|}{ Pseudoviridae } \\
\hline & Pseudovirus & Saccharomyces cerevisiae Ty1 virus \\
\hline \multirow{2}{*}{ Metaviridae } & Silevirus & Glicine max SIRE1 virus \\
\hline & Matavirus & Saccharomyces cerevisiae Ty3 virus \\
\hline
\end{tabular}

Tabla 1. Familias, géneros y especies tipo de los virus patógenos de plantas. La clasificación se ha realizado en base al material genético que presentan, según los criterios de la ICTV.

Como se verá más adelante esta Tesis ha abordado diferentes aspectos del movimiento intracelular de los virus así como los requerimientos estructurales de las MPs implicadas en la translocación intercelular. Para ello se ha utilizado un virus patógeno de plantas, de genoma de RNA, simple hebra y polaridad positiva: el Virus de las manchas necróticas del melón (Melon necrotic spot virus, MNSV). El MNSV se clasifica taxonómicamente dentro de la familia Tombusviridae, género Carmovirus. 


\section{LA FAMILIA Tombusviridae}

La familia Tombusviridae está compuesta por 8 géneros; Tombusvirus, Aureusvirus, Avenavirus, Machomovirus, Necrovirus, Panicovirus, Dianthovirus y Carmovirus. A este último petenece el MNSV. Los genomas de los miembros de la familia Tombusviridae se componen de moléculas únicas de RNA de simple cadena con polaridad positiva, a excepción del género Dianthovirus, cuyos miembros presentan genomas divididos. El tamaño del genoma oscila entre 3,7-4,7 kb, dependiendo del género, presenta extremos 3' no poliadenilados y, aunque la mayoría no las tiene, se han descrito estructuras de tipo CAP en los extremos $5^{\prime}$ del Virus del moteado del clavel (Carnation mottle virus, CarMV), el Virus del mosaico necrótico del trébol rojo (Red clover necrotic mosaic virus, RCNMV) y el Virus del mosaico clorótico del maíz (Maize chlorotic mottle virus, MCMV). Además, en algunos géneros se han detectado RNAs defectivos de interferencia (Defective Interfering RNAs, DI RNA) y RNAs o virus satélites asociados (revisado White y Nagy, 2004).

En lo referente a la organización genómica existen caracteres que se han mantenido muy conservados entre los miembros de la familia. La mayoría presenta en su genoma hasta cinco pautas de lectura abierta (Open reading frame, ORF) excepto los géneros Dianthovirus y Avenavirus, que presentan cuatro. Además, los géneros Panicovirus y Machlomovirus tienen mecanismos de desplazamiento de pauta de lectura (Frame shift, FS) y lectura a través del codón de parada (Read throught, RT) en sus ORFs 4 y 3 , respectivamente, que podrían dar lugar a proteínas de mayor tamaño. En general, a excepción del MCMV, tras un extremo 5 ' no codificante se halla el gen de la RdRp viral. Esta ORF, presenta un codón de parada débil interno cuya activación da lugar a una proteína más pequeña, a excepción de los Dianthovirus que utilizan un mecanismo de FS para obtener la misma. Ambas proteínas (la RdRp completa y la parcial) se han detectado durante una infección viral y son imprescindibles para la replicación. Del análisis de la secuencia de estas RdRps virales se dedujo que están altamente conservadas y cabe destacar el motivo GDD junto con el de unión a RNA (helicasa), común con otras RdRp de otras familias virales. El resto de ORFs del genoma de la familia Tombusviridae codifican las proteínas de movimiento (MP) y de la cápsida (CP). Mientras que las ORF 1 y 2 se traducen a partir del RNA genómico (gRNA), las demás lo hacen a partir de RNAs subgenómicos virales (sgRNA) derivados del gRNA.

Como característica general de la familia Tombusviridae es interesante destacar la formación de viriones con simetría icosahédrica $(T=3)$ y compuestos por 180 copias de una misma proteína, la proteína de la cápsida o CP. De acuerdo con las características filogenéticas de la CP, los miembros de esta familia pueden dividirse en dos grandes grupos. Al primero pertenecen los géneros Aureusvirus, Avenavirus, Carmovirus, Dianthovirus y Tombusvirus. Sus viriones son partículas redondeadas de superficie rugosa y un diámetro de aproximadamente $32-35 \mathrm{~nm}$, compuestos por subunidades con tres dominios estructurales distintos: (i) $\mathrm{R}$, es el dominio interno $\mathrm{N}$ terminal, posee la mayor densidad de residuos con 
carga positiva y es el encargado de interaccionar con el RNA; (ii) S, forma una estructura en barril $\beta$ que constituye el esqueleto de la cápside y conecta con un brazo amino terminal al dominio $\mathrm{R}$ y (iii) $\mathrm{P}$, es el dominio $\mathrm{C}$-terminal protuberante, característica que le confiere la apariencia granular o rugosa al virión. Al segundo pertenecen los géneros Machlomovirus, Necrovirus y Panicovirus que se caracterizan por carecer del extremo protuberante $\mathrm{P}$, por lo que sus viriones presentan una superficie de aspecto no rugoso. Respecto a las proteínas de movimiento (MP) podemos diferenciar hasta tres grupos filogenéticos dentro de la familia: (i) los Avenavirus, Carmovirus, Machlomovirus, Necrovirus y Panicovirus presentan dos proteínas de movimiento de masa molecular de 7-9 y 8-9 kDa; (ii) los Tombusvirus y Aureusvirus poseen una proteína de movimiento con masa molecular de 22-27 kDa junto con una adicional de 14$19 \mathrm{KDa}$ implicada en el aumento de la severidad de los síntomas y (iii) el género Diantovirus, con una única proteína de masa molecular de 35 kDa (Giesman-Cookmeyer et al., 1995; Solovyev et al., 1997; Li et al., 1998; Cañizares et al., 2001; Huppert et al., 2002).

La replicación de los miembros de esta familia ocurre en el citoplasma celular y posiblemente en vesículas membranosas asociadas con el retículo endoplásmico o algunos orgánulos (peroxisomas, mitocondrías y cloroplastos). Asimismo, el ensamblaje del virión tiene lugar en el citoplasma aunque también se han descrito casos en los que se da en la mitocondría y el núcleo. Los viriones formados se acumulan en el citoplasma o en vacuolas citoplasmáticas.

En lo que concierne a las virosis provocadas por miembros de la familia Tombusviridae, éstas presentan una amplia distribución mundial, siendo especialmente incidentes en zonas de climas templados. Respecto a la gama de hospedadores afectan tanto plantas mono como dicotiledóneas y la sintomatología ocasionada presenta determinados rasgos comunes destacando el moteado, el arrugamiento, la necrosis y la deformación de las hojas de las plantas afectadas. Sin embargo, algunas especies pueden ser no sintomáticas en determinados hospedadores. Todas las especies de esta familia pueden transmitirse por inoculación mecánica, mientras que algunas por contacto o a través de semillas. Además, algunos hongos del genero Olpidium y ciertas especies de escarabajos pueden ser vectores para la transmisión de algunos miembros de esta familia. Por último, se ha descrito la presencia de estos virus en suelos y aguas de modo que la mayoría pueden ser transmitidos desde estos medios con dependencia o no del vector.

\section{EL GÉNERO Carmovirus}

Los viriones del género Carmovirus están formados en un $86 \%$ por proteína, principalmente la CP, y un $14 \%$ de ácido nucleico, mayoritariamente RNA de simple cadena y polaridad positiva, con un tamaño de 3879 a 4450 nucleótidos. Generalmente, sólo el RNA genómico se encapsida, aunque algunas especies también empaquetan RNAs defectivos interferentes o RNAs satélites. Respecto a los extremos no traducibles del genoma de 
Carmovirus, pueden existir modificaciones tipo CAP en el $5^{\prime}$, mientras que el $3^{\prime}$ terminal adquiere una estructura semejante a la de los RNA celulares; colas poli(A), como ocurre en los RNAs mensajeros (mRNA), o estructuras terciarias terminales similares a los RNAs de transferencia (tRNA).

El Virus del moteado del clavel (Carnation mottle virus, CarMV) es la especie tipo para este género, por tanto, las características de su organización genómica son comunes para otros miembros del grupo (Figura 2). El CarMV codifica en su genoma cinco ORFs. En el extremo $5^{\prime}$ del genoma se halla una región no traducible de 69 nucleótidos. Tras el primer AUG hay un codón de parada débil cuya lectura a través da lugar a una proteína de $86 \mathrm{kDa}$. Sin embargo, una proteína de $28 \mathrm{kDa}$ se traduce por la activación del mismo. En la región central del genoma se encuentran las ORF de dos pequeñas proteínas de 7 y $9 \mathrm{kDa}$. Por último, en el extremo 3' se halla la ORF que codifica para una proteína de $38 \mathrm{kDa}$, correspondiente en todos los Carmovirus con la proteína de cubierta, seguida de una región no traducible de 290 nucleótidos. Las regiones $3^{\prime}$ y $5^{\prime}$ no traducibles presentan una alta homología. De las regiones traducibles, es la RdRp y particularmente el dominio situado alrededor del motivo GDD donde se hallan las secuencias más conservadas. La parte más variable del genoma es la ORF de la $\mathrm{CP}$, además, dentro de ésta, el dominio $\mathrm{P}$ es el menos conservado. Interesantemente, existe una covariación entre los residuos que ocupan las posiciones 164 (localizada en el dominio S) y 331 (situada dentro del dominio P) de la CP del CarMV, lo que sugiere la presencia de interacciones entre estas dos regiones de la proteína implicadas en la estructura terciaria (Cañizares et al., 2001). Asimismo, se ha descrito otra covariación entre cinco aminoácidos específicos de la secuencia de la CP de otro Carmovirus, el Virus de la rotura de la flor del pelargonium (Pelargonium flower break virus, PFBV) en un proceso de adaptación sujeto a pases seriados en el huésped experimental Chenopodium quinoa (Rico et al., 2006).

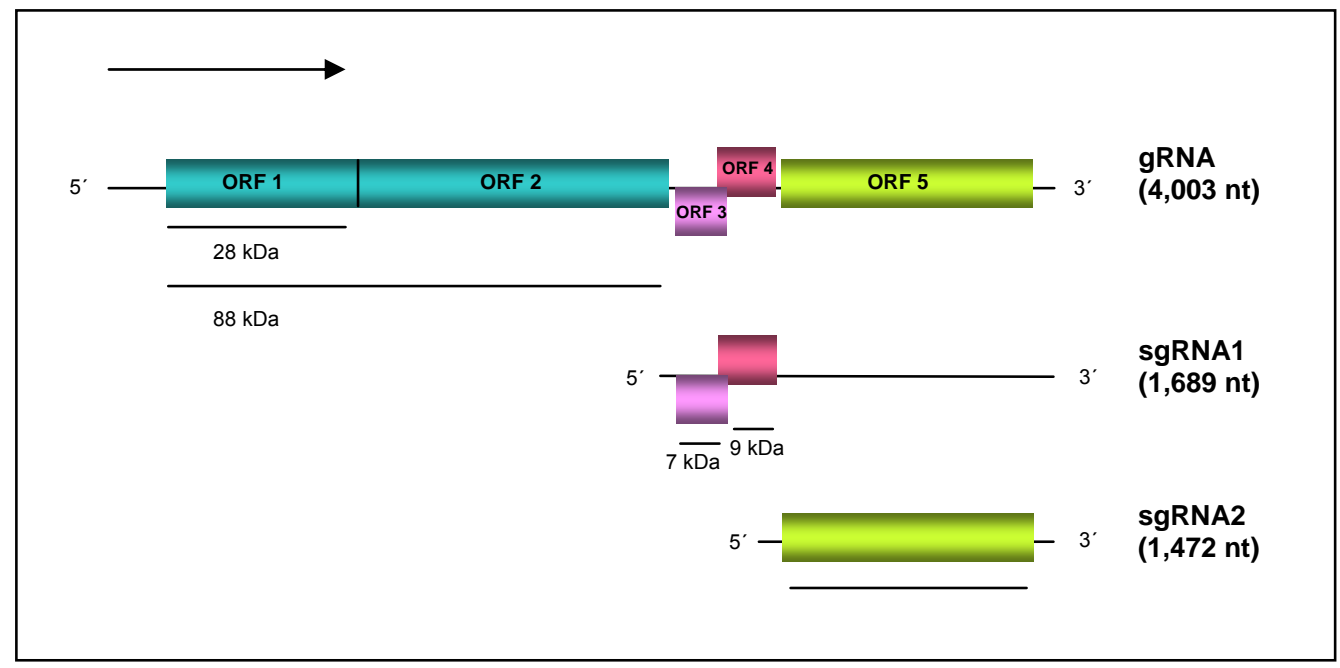

Figura 2. Representación de la organización y expresión del genoma del Virus del moteado del clavel (CarMV). Los rectángulos representan las pautas de lectura abiertas (ORF) y las líneas inferiores el producto de su traducción. 
Sendos estudios realizados con el CarMV y el Virus del arrugamiento del nabo (Turnip crinkle virus, TCV) han puesto de manifiesto características comunes con otros Carmovirus. En primer lugar, en todos los casos, la traducción de las proteínas de movimiento y de la cápsida tiene lugar a través de RNA subgenómicos (Harbison et al., 1984; Harbison et al., 1985). Por ejemplo, en el TCV, mientras que el sgRNA de 1,45 kb sirve para la síntesis de la proteína de la cápsida (p38) (Carrington et al., 1987), el de 1,7 kb actúa como RNA bicistrónico en la traducción de las proteínas de movimiento p8 y p9 (Hacker et al., 1992). Los extremo 5 ' de los sgRNA1 y sgRNA2 del CarMV se halla a 1689 y 1472 nucleótidos, respectivamente, del extremo $3^{\prime}$ del genoma (Carrington y Morris, 1986). Para el TCV, el extremo $5^{\prime}$ del sgRNA2 se ha mapeado a 1446 nucleótidos del 3' del gRNA (Carrington et al., 1987).

El papel desempeñado por las proteínas virales en replicación, encapsidación y movimiento de Carmovirus ha sido bien estudiado en experimentos de mutagénesis dirigida para el TCV (Heaton et al., 1991; Hacker et al., 1992). En estos trabajos se pone de manifiesto que los productos de la ORF1 y 2 del TCV (p28 y p88) son requeridos para la replicación del virus. Sin embargo, mutantes para las ORF 3 y 4 (p8 y p9) son capaces de replicar pero no de infectar a las plantas, lo que sugiere su papel en el movimiento célula a célula. Por último, mutantes en la ORF 5 (CP) son capaces de replicar y, en algunos casos, moverse célula a célula pero no a larga distancia.

Debido a que los genomas de Carmovirus se componen de RNAs de polaridad positiva y simple hebra, tras entrar el virus en la célula debe traducir las ORFs de las RdRp virales. Una vez sintetizadas, éstas llevarán a cabo la síntesis de las cadenas de RNA de polaridad negativa a partir del extremo 3' de las de polaridad positiva (Wang y Wong, 2004). En el reconocimiento de este sitio de iniciación por la RdRp participan elementos en cis del genoma tanto de estructura primaria como secundaria (Morozov et al., 1995; Siegel et al., 1997; Nagy et al., 1998a; Nagy et al., 1998b; Panavas et al., 2002a; Panavas et al., 2002b). Así, el extremo 3’ del gRNA de polaridad positiva, se pliega en una serie de horquillas y de elementos promotores que son reconocidos por la RdRp en el comienzo de la síntesis (White y Nagy, 2004). En los Carmovirus, el promotor mínimo incluye los 19 últimos nucleótidos del extremo 3' del RNA genómico de polaridad positiva y se conoce como elemento Pr. Además, estudios realizados con el TCV, han puesto de manifiesto que este elemento se corresponde con la horquilla 3' terminal flanqueada por la secuencia CUGCCC (Stupina y Simon, 1997; Carpenter y Simon, 1998). Este elemento estructural está muy conservado en los Carmovirus e incluso entre aislados de una misma especie (Cañizares et al., 2001). Por otro lado, el extremo 3' de la cadena de polaridad positiva puede estar a su vez implicado en el control de la traducción (Qu y Morris, 2000). Además, en el TCV y el RNA satelite $C$ asociado (SatC) se han descrito los elementos conocidos como "enhancer". Éstos son estructuras secundarias en horquilla del gRNA que pueden actuar estimulando la replicación y la transcripción de estos virus de RNA (Nagy et al., 1999; Nagy et al., 2001; Sun y Simon, 2006). 
Respecto a la síntesis de los RNAs de polaridad positiva, estudios realizados con el SatC asociado al TCV han puesto de manifiesto la presencia de varias regiones promotoras: (i) una secuencia consenso de Carmovirus (Carmoviruses consensus sequence, CCS), $C_{2-3}$ A/U A/U $\mathrm{A} / \mathrm{U}$; (ii) un segmento de $11 \mathrm{nt}$ localizado en $3^{\prime}$ que abarca la CCS; (iii) un elemento $5^{\prime}$ proximal específico de secuencia y (iv) un motivo horquilla-1 formado por 30 nt (Guan et al., 1997; Guan et al., 2000a; Guan et al., 2000b).

Como consecuencia del proceso de replicación, se forman RNAs de doble cadena compuestos por la cadena positiva y la negativa y con tamaños relativos a los RNAs genómicos y subgenómicos. El significado de estas formas replicativas doble cadena no está claro pero recientemente se ha postulado la implicación de las mismas en la síntesis desigual de cadenas positivas frente negativas (Panavas et al., 2006).

Para la síntesis de los RNAs subgenómicos se han propuesto al menos tres mecanismos alternativos (Koev y Miller, 2000): (i) a partir del extremo 3' de la cadena positiva del gRNA mediante una terminación prematura de la transcripción de las cadenas negativas antes de completar el tamaño genómico, lo que a su vez servirá de molde para las cadenas positivas; (ii) la iniciación interna de la RpRd, a partir del gRNA de polaridad negativa y (iii) una síntesis discontinua. En el TCV y el Virus de los anillos cloróticos del hibiscus (Hibiscus chlorotic ringspot virus, HCRSV) se ha demostrado la actividad promotora de regiones que preceden el codón de inicio de la traducción en los sgRNA (Wang y Simon, 1997; Li y Wong, 2006). Por otro lado, el mapeo de las regiones $5^{\prime}$ de los sgRNA ha puesto de manifiesto la capacidad de las mismas de plegarse adoptando estructuras secundarias tipo horquilla. Más aún, éstas presentan homología de secuencia con regiones $5^{\prime}$ de los gRNA y se mantienen conservadas entre los Carmovirus (Li y Wong, 2006). Las características anteriores son comunes con otros virus de plantas de polaridad positiva y apuntarían al modelo de iniciación interna para la síntesis de RNAs subgenómicos. Es probable que la regulación de la síntesis de las proteínas virales esté determinada por la modulación de la expresión de sus respectivos sgRNA. En este sentido, podrían tener importancia las diferencias en la afinidad de la RdRp por los promotores de cada uno de ellos. En este sentido, se ha observado que los RNAs de los subgenómicos del CarMV se acumulan diferencialmente en el tiempo en plantas de Chenopodium quinoa (GarciaCastillo et al., 2003).

Por su parte, en lo que concierne a las MP, estudios in vitro con CarMV han mostrado algunas propiedades de las mismas. Se ha demostrado que $p 7$, la proteína más pequeña de las dos que intervienen en el movimiento célula a célula, es capaz de unir RNA de forma cooperativa e inespecífica de secuencia (Marcos et al., 1999). Además, el motivo implicado en la unión corresponde con la región central de la proteína (residuos 17-35) y presenta una estructura secundaria en $\alpha$-helice muy conservada entre los Carmovirus (Vilar et al., 2001). Por último, se ha demostrado que dicha estructura condiciona la capacidad de unión a RNA de p7 y modula, mediante un mecanismo adaptativo, la interacción RNA-proteína (Vilar et al., 2005). 
Por otro lado, p9 presenta dos dominios hidrofóbicos separados por un bucle que se insertan en la membrana del retículo endoplasmático (RE) dejando los extremos $\mathrm{N}$ y $\mathrm{C}$ terminales de la proteína expuestos al lado citoplasmático (Vilar et al., 2002). Como consecuencia del conjunto de características halladas para las proteínas de movimiento de CarMV se ha propuesto un modelo de movimiento en el que p7 es la parte soluble encargada de unir el RNA viral y llevarlo hacía p9, anclada a la membrana del RE (Marcos et al., 1999; Vilar et al., 2001; Vilar et al., 2002). El complejo de RNA y proteínas de movimiento difundiría por el RE hasta llegar a los plasmodesmos celulares para moverse a la célula vecina.

En lo que respecta a la $\mathrm{CP}$, se ha comprobado que, además de ser la encargada de la formación de los viriones, está implicada en otras funciones. Por ejemplo, la del TCV actúa en la modulación de la sintomatología o en la acumulación viral (Kong et al., 1997; Wang y Simon, 2000) así como en la supresión del silenciamiento génico postranscripcional (Posttranscriptional gene silencing, PTGS) (Qu y Morris, 2003). Además, esta proteína es necesaria para que se dé la invasión sistémica del virus (Hacker et al., 1992).

\section{EL VIRUS DE LAS MANCHAS NECRÓTICAS DEL MELÓN, MNSV}

El virus de las manchas necróticas del melón (Melon necrotic spot virus, MNSV) es el agente causal de la enfermedad del cribado del melón. Este virus es un miembro del género Carmovirus, perteneciente a la familia Tombusviridae (Tabla 1). Está formado por partículas isométricas de unos $30 \mathrm{~nm}$ de diámetro, constituidas aproximadamente por 180 subunidades proteicas. El genoma del MNSV está compuesto por una molécula de RNA monocatenario de polaridad positiva de $4.3 \mathrm{~kb}$. Por comparación con otras secuencias de nucleótidos de virus relacionados se ha postulado que en el genoma del MNSV se encuentran codificadas al menos cinco proteínas flanqueadas por dos regiones no traducibles (Figura 3) (Riviere y Rochon, 1990). La 5 'UTR presenta un tamaño de 87 a $95 \mathrm{nt}$, dependiendo del aislado, y se desconoce si contiene alguna estructura tipo "cap" en su extremo. La 3'-UTR tiene un tamaño de 280 nt y no está poliadenilada pero contiene estructuras secundarias, similares a las descritas para otros Carmovirus, que podrían ser esenciales para la replicación y/o traducción. En esta región se encuentran los elementos estructurales responsables de la superación de la resistencia al virus debida al gen nsv de melón (Diaz et al., 2004). Los aislados como el MNSV-264, capaces de infectar plantas de melón portadoras del gen nsv, presentan una secuencia nucleotídica de la región 3'UTR muy diferente a los que no la superan (Diaz et al., 2004).

La ORF más próxima al extremo 5' es una proteína de 29 kDa (p29) que finaliza con un codón ámbar. Continuando la lectura por dicho codón se obtiene una proteína de 89 kDa (p89) que contiene el motivo GDD y el dominio característico de las RdRp, por lo que probablemente esta proteína esté implicada en la replicación del virus. Las dos ORFs situadas en la parte central del genoma constituyen las proteínas p7A y p7B, de $7 \mathrm{kDa}$ cada una. Dichas proteínas podrían facilitar el movimiento a corta distancia por comparación con otras proteínas de Carmovirus implicadas en esta función (Hacker et al., 1992; Marcos et al., 1999). Por último, la 
ORF del extremo 3' representa la proteína de cubierta. Esta proteína, de $42 \mathrm{kDa}$, está implicada en la encapsidación del virus y probablemente en el movimiento a larga distancia dentro de la planta. Además, puede desempeñar un papel importante en la transmisión del virus por el vector (Riviere et al., 1989; Ohshima et al., 2000).

Asimismo, la detección de dos RNAs subgenómicos de 1.9 kb (sgRNA1) y $1.6 \mathrm{~kb}$ (sgRNA2) que comparten el mismo extremo 3' del gRNA ha permitido proponer una estrategia similar a la de otros Carmovirus para la expresión del genoma del MNSV. Básicamente, el gRNA actuaría como mensajero para la síntesis de las proteínas p29 y p89. Las proteínas p7A y p7B se producirian a partir del sgRNA1 mientras que la proteína de cubierta se obtendría a partir del sgRNA2 (Riviere et al., 1989).

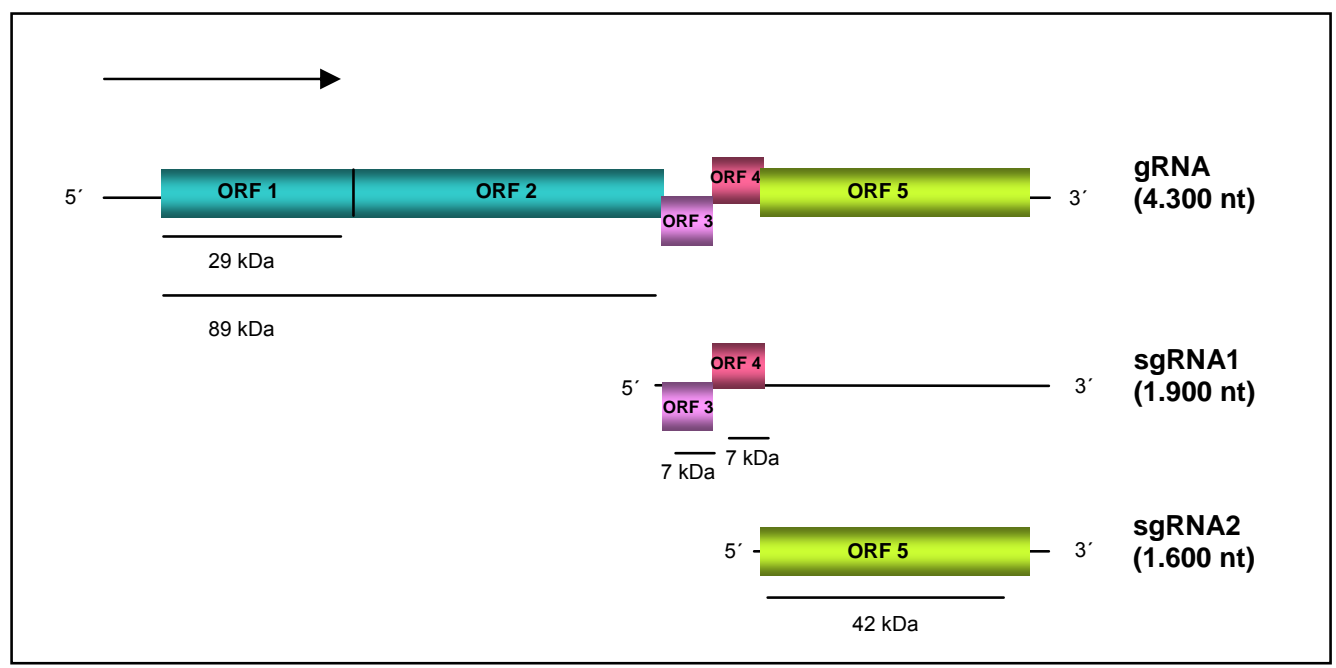

Figura 3. Representación de la organización y expresión del genoma del Virus de las manchas necróticas del melón (MNSV). Los rectángulos representan las pautas de lectura abierta (ORF) y las líneas inferiores el producto de su traducción.

EI MNSV es principalmente trasmitido por un hongo del suelo denominado Olpidium bornovanus (Satiyanci) Karting que pertenece a la clase de los Quitridiomicetes dentro del orden Quitridiales. La capacidad infectiva de un suelo que ha albergado plantas que han desarrollado la enfermedad puede durar varios años debido a la formación de esporas de resistencia que pueden permanecer largos periodos de tiempo sin perder su viabilidad. La transmisión del MNSV por parte de O. bornovanus tiene lugar mediante un proceso que se ha denominado adquisición in vitro (Campbell et al., 1996). Cuando el virus y el hongo se encuentran en el agua o en la solución del suelo se produce la adsorción de las partículas víricas a la membrana de la zoospora. En esta unión parecen estar implicadas determinadas regiones de la proteína de cubierta (Kakani et al., 2001) y las glicoproteínas de la membrana de las zoosporas (Kakani et al., 2003). Durante la fase de penetración de la zoospora en la célula vegetal se produce la infección del virus en la planta. Tras la formación de la espora de resistencia del hongo, el virus queda unido a la parte exterior de la pared de la espora y al 
germinar ésta se produce de nuevo la absorción del virus a las zoosporas liberadas. Además, algunos aislados del MNSV presentes en Japón y California pueden ser trasmitidos por coleópteros del género Diabrotica. Sin embargo, en nuestra zona de cultivo este medio de transmisión no es importante, al no estar presente el vector. El MNSV también se transmite por semilla, aunque tiene que ser facilitada por el vector $O$. bornovanus. Así, la frecuencia de transmisión aumenta de un $2 \%$ hasta un $50 \%$ con la presencia del hongo en experimentos realizados utilizando semillas contaminadas con el virus, el cual se localiza principalmente en la cubierta externa de la semilla (Campbell et al., 1996). Además, el MNSV se puede transmitir fácilmente de manera mecánica, por lo que se recomienda mantener limpios los utensilios utilizados para la poda de plantas.

La enfermedad del cribado del melón afecta a especies de gran importancia hortícola. Fue descrita por primera vez en Japón sobre plantas de melón (Cucumis melo) cultivadas en invernadero, aunque posteriormente se ha extendido por el resto del mundo afectando también a pepino (Cucumis sativus) y sandía (Citrullus lanatus). Así, durante la primera mitad de la década de los 80 , la incidencia de la enfermedad fue superior al $60 \%$ en cultivos hidropónicos de pepino en Holanda y Reino Unido (Bos et al., 1984; Tomlinson y Thomas, 1986). También cabe destacar las pérdidas provocadas en cultivos protegidos de melón en California y Grecia.

En España, esta enfermedad se conoce desde 1984, apareciendo por primera vez en Almería sobre cultivos de melón en invernadero (Luís-Arteaga, 1986). Posteriormente, se ha ido extendiendo a otras zonas productoras como Murcia, Alicante, Valencia, Islas Baleares y Canarias (Juárez et al., 1993; Luis-Arteaga, 1994). En cultivos de sandía, la enfermedad parece estar controlada por el uso de plantas injertadas sobre Cucurbita fuccifolia, una especie resistente. En pepino no parece ser un problema importante (Luis-Arteaga, 1994). Es importante destacar que aunque la enfermedad siempre se ha descrito afectando a cultivos protegidos también puede dañar a cultivos al aire libre.

Aunque los síntomas dependen de las condiciones ambientales, la sintomatología más característica en plantas de melón es la aparición en hojas jóvenes de lesiones redondas de color marrón y de 1-2 mm de diámetro, que suelen evolucionar a necrosis dando lugar a un aspecto de "cribado". En hojas adultas pueden aparecer lesiones necróticas que se extienden por los nervios. En tallos y sobre todo en el cuello de la planta aparecen estrías pardas con aspecto de acorchadas. Normalmente aparece una reducción en el crecimiento del fruto y en ocasiones lesiones necróticas. El síntoma más relevante, al que se le atribuye el nombre de colapso o muerte súbita del melón, es la marchitez y muerte rápida de la planta, sobre todo en condiciones de estrés hídrico y plena producción (Figura 4).

El diagnóstico visual en campo de los síntomas puede no identificar la enfermedad, ya que éstos dependen de las condiciones ambientales y pueden llevar a la confusión con otras patologías que se manifiestan de forma similar. Por tanto, es necesario el uso de técnicas de diagnóstico que ofrezcan seguridad para una detección precisa y temprana de la infección. En 
un principio se utilizaba la inoculación de cotiledones de plantas de melón de la variedad Galia por su gran sensibilidad al MNSV. Sin embargo, este método presenta algunos inconvenientes derivados de su extrema lentitud y falta de fiabilidad, al presentar falsos negativos debido a que la respuesta depende de las condiciones ambientales y del manejo de la técnica. Además, los bioensayos no permiten el análisis de un gran número de plantas. Por el contrario, los métodos serológicos, como el test ELISA, presentan mayor rapidez y seguridad que el anterior. Asimismo, su automatización facilita el examen de muchas muestras simultáneamente. Sin embargo, se ha observado variabilidad en el comportamiento serológico y biológico de aislados de plantas procedentes de diferentes zonas de producción. Otra técnica más reciente, capaz de diferenciar esta variabilidad del virus, consiste en la hibridación molecular con ribosondas marcadas con digoxigenina siendo una estrategia rápida, más sensible que la utilización de anticuerpos e igualmente adaptable a un análisis masivo de muestras (Pallas et al., 1998). Recientemente se ha puesto a punto un método para la detección en agua y planta del MNSV mediante hibridación molecular no isotópica (Gosalvez-Bernal et al., 2003).

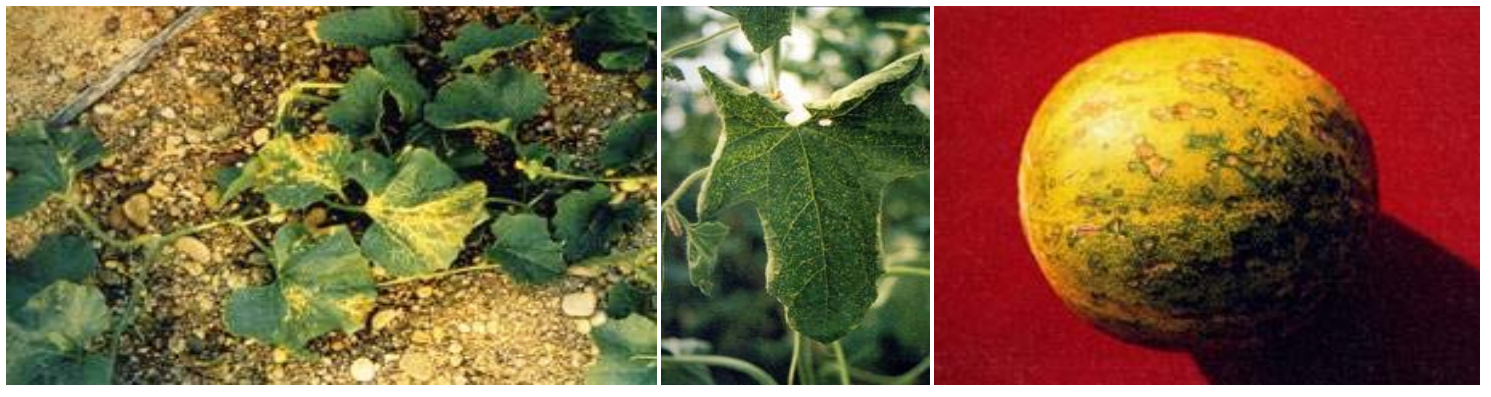

Figura 4. Planta y fruto de melón infectados por el MNSV, sintomatología característica. Síntomas en hoja con lesiones redondeadas cloróticas que derivarán en necróticas, necrosis de la nervadura y marchitamiento y secado de las hojas. Fruto con manchas necróticas en su superficie (adaptado de Luis-Arteaga, 1994).

Durante el desarrollo de la presente memoria se van a tratar problemas relacionados con el ciclo de infección del virus que requieren conocer necesariamente algunos aspectos de la fisiología y biología de la célula vegetal. En los apartados siguientes se revisarán, por tanto, los relacionados más directamente.

\section{LA CÉLULA VEGETAL: CONCEPTOS BÁSICOS}

Una serie de características diferencian a las células vegetales de las animales (Figura 5), entre ellas cabe destacar la presencia de: (i) los cloroplastos, orgánulos rodeados por dos membranas que atrapan la energía electromagnética derivada de la luz solar y la convierten en energía química mediante la fotosíntesis, utilizándola después para sintetizar azúcares a partir del CO2 atmosférico; (ii) las vacuolas, que constituyen el depósito de agua y de varias sustancias químicas tanto de desecho como de almacenamiento. La presión ejercida por el agua de la vacuola se denomina presión de turgencia y contribuye a mantener la rigidez de la célula, por lo que el citoplasma y núcleo de una célula vegetal adulta se presentan adosados a las paredes celulares. La pérdida del agua resulta en un fenómeno denominado plasmolisis por 
el cual la membrana plasmática se separa de la pared y condensa el citoplasma en el centro del lumen celular y (iii) la pared celular, le confiere la forma a la célula, cubriéndola a modo de exoesqueleto, y le da la textura a cada tejido. Es el componente que le otorga protección y sostén a la planta.

A continuación se revisa de manera breve algunos elementos característicos de las células vegetales como son la pared celular y los plasmodesmos y otros que, no siendo específicos de éstas, merecen dicha revisión dado el tipo de estudios de la presente Tesis, como es el caso del citoesqueleto.

7.1 La pared celular. Su principal componente estructural es la celulosa, entre un $20-40 \%$, característica que le convierte en el compuesto orgánico más abundante en la tierra. La celulosa está formada por monómeros de glucosa unidos de manera lineal, en paralelo y enlazados por puentes de hidrógeno, formando microfibrillas de 10 a $25 \mathrm{~nm}$ de espesor. La unión entre las unidades de glucosa se da por enlaces 1-4 $\beta$, lo que le hace muy difícil de hidrolizar. Las microfibrillas se combinan mediante las hemicelulosas y la pectina formando una estructura llamada macrofibrillas, con hasta medio millón de moléculas de celulosa. Entre las sustancias que se incrustan en la pared se encuentra la lignina, la cutina y la suberina, impermeabilizando las paredes celulares.

La pared celular, según la ordenación de las fibrillas de celulosa y la proporción de sus constituyentes, puede clasificarse en primaria y secundaria. La pared primaria se encuentra en células jóvenes y áreas en activo crecimiento, por ser relativamente fina y flexible debido, en parte, a la presencia de sustancias pépticas y la disposición desordenada de las microfibrillas de celulosa. La pared secundaria aparece sobre las paredes primarias, hacia el interior de la célula, y se forma cuando la célula ha detenido su crecimiento y elongación. Se encuentra en células asociadas al sostén y a la conducción. El protoplasma de estas células generalmente muere a la madurez.

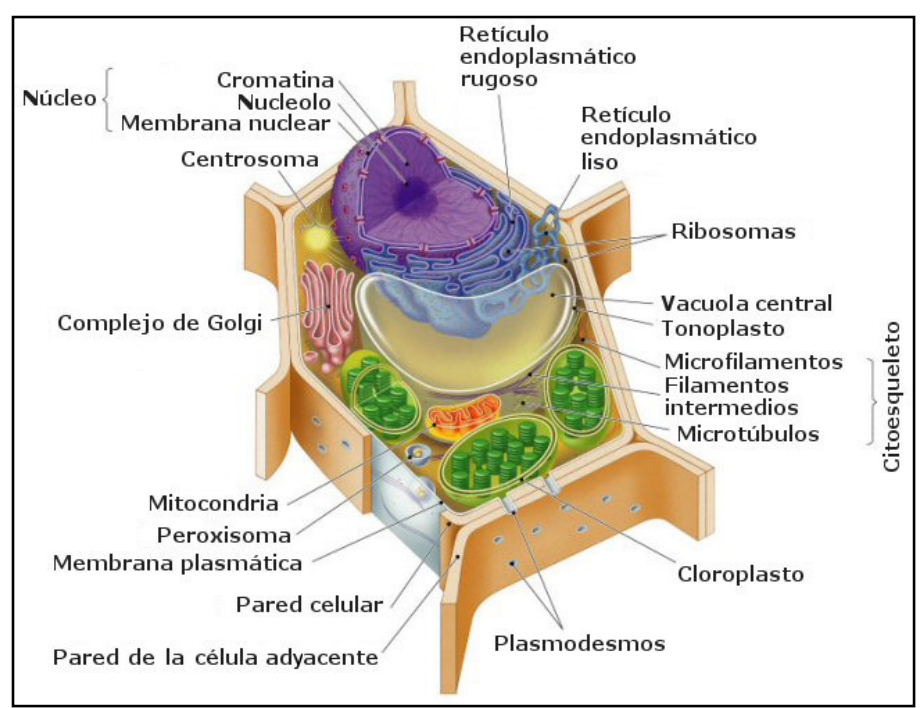

Figura 5. Representación de la célula vegetal mostrando un esquema de sus principales orgánulos, algunos de ellos: cloroplastos (en verde), vacuola (en blanco) o pared celular (en marrón), característicos de este tipo celular 
7.2 Los plasmodesmos. Otra característica de las células vegetales es la presencia de puentes citoplasmáticos que atraviesan la pared celular denominados plasmodesmos (Figura 6). Estos microcanales son utilizados como comunicaciones intercelulares que permiten la circulación de moléculas entre citoplasmas de células vecinas. Los plasmodesmos atraviesan las dos paredes adyacentes por perforaciones acopladas que se denominan poros cuando sólo hay pared primaria, y punteaduras, si además se ha desarrollado la pared secundaria. Normalmente presentan un diámetro de $40 \mathrm{~nm}$ y están formados por dos tipos de membranas, la plasmática y la del RE. La membrana plasmática, continua entre células adyacentes, define la parte exterior del poro mientras que su eje axial es recorrido por una estructura cilíndrica, conocida como desmotúbulo, formada por la membrana del RE junto con determinados factores proteicos. La región entre la membrana externa y el desmotúbulo es la lámina citoplasmática y está segmentada en canales transportadores. Entre las proteínas que se encuentran en los plasmodesmos cabe destacar: (i) las conexinas, también presentes en las uniones gap de las membranas plasmáticas de las células animales; (ii) las protein-kinasas dependientes de calcio (Calcium-dependent protein kinase, CDPK), probablemente involucradas en la regulación de la permeabilidad; (iii) las proteínas del citoesqueleto, miosina y actina, responsables del dinamismo del plasmodesmo, localizándose esta última dispuesta en espiral alrededor del desmotúbulo donde puede actuar regulando el tamaño diametral del mismo conocido como limite de exclusión molecular (size exclusion limit, SEL); (iv) las proteínas de unión a calcio y centrinas o proteínas tipo centrinas, desempeñando el calcio un papel importante en la regulación del transporte intracelular; (v) las dendrinas, que modifican el plasmodesmo en respuesta a estrés y (vi) la pectina metilesterasa (Pectin methyl esterase, PME), proteínas que se localizan en microdominios del RE próximos a los plasmodesmos cuya actividad enzimática es responsable de la desesterificación de algunas proteínas de secreción. Claramente, los plasmodesmos no semejan las uniones gap de las membranas de células animales, sino que son estructuras casi tan complejas y selectivas como los poros presentes en las membranas nucleares (Zambryski, 1995; Waigmann et al., 1998).

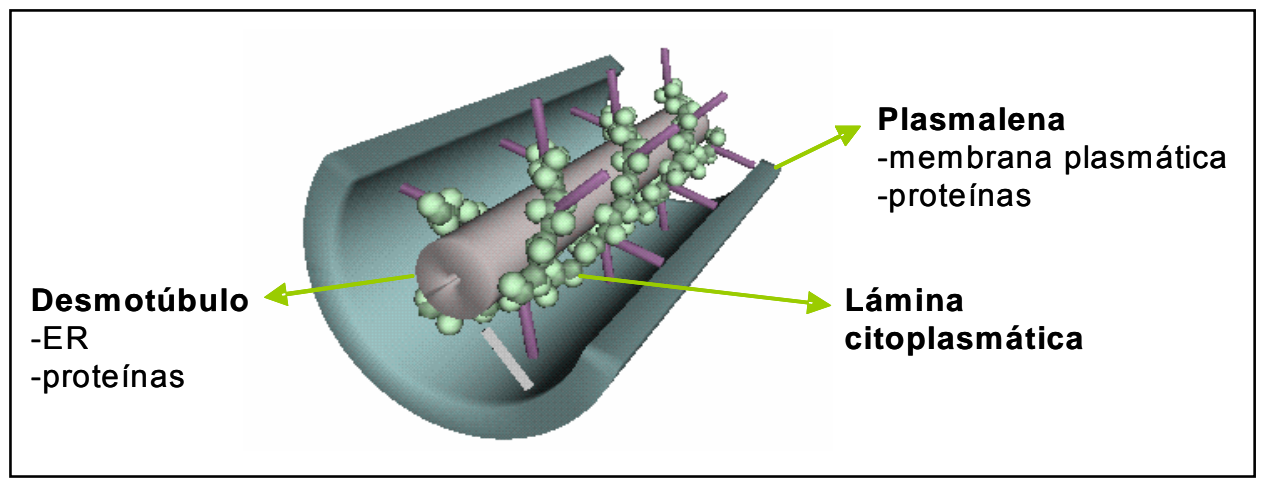

Figura 6. Representación esquemática del plasmodesmo de una célula vegetal. El desmotúbulo (en gris), atraviesa la cavidad central del plasmodesmo, rodeado de un espacio intermedio, o lámina citoplasmática, compuesto por proteínas (en verde) y elementos radiales (en rosa) que regulan las dimensiones del canal para controlar el transporte de macromoléculas a través del mismo. La envoltura externa la forman la membrana citoplasmática y proteínas. 
7.3 El Citoesqueleto. La célula eucariota presenta en su interior un entramado de microtúbulos y microfilamentos conocido como citoesqueleto. Entre sus funciones descritas está la de actuar como soporte interno, la de anclar estructuras celulares y la de intervenir en procesos de división y movimiento celular. El citoesqueleto desempeña un importante papel en el transporte intracelular, promoviendo el movimiento de vesículas y orgánulos. Este último aspecto es el que nos va a interesar para el desarrollo de la presente memoria.

Los microfilamentos están compuestos por moléculas de actina y miosina y su diámetro oscila entre 5-7 nm. La actina es una proteína globular que se encuentra tanto en la forma polimerizada como en la no polimerizada. La actina polimerizada puede estar, a su vez, asociada a otras proteínas, ya sean estructurales o reguladoras, como la miosina que provoca la contracción de los microfilamentos al permitir que la actina se desplace sobre ella.

Los microtúbulos son estructuras tubulares de $25 \mathrm{~nm}$ de diámetro que se originan en los centros organizadores de microtúbulos y que se extienden a lo largo de todo el citoplasma. Éstos se hallan en las células eucariotas y están formados por la polimerización de un dímero de dos proteínas globulares, la $\alpha$-tubulina y la $\beta$-tubulina, que pueden polimerizar y despolimerizar según las necesidades de la célula. De este modo, intervienen en diversos procesos celulares que involucran el desplazamiento de vesículas de secreción, el movimiento de orgánulos, el transporte intracelular de sustancias, así como en la división celular (mitosis y meiosis). Además, constituyen la estructura interna de los cilios y los flagelos. Los microtúbulos son más flexibles pero más duros que la actina.

Volviendo sobre los aspectos característicos de las plantas cabe mencionar que el crecimiento de un vegetal involucra tanto división como agrandamiento celular. Las células originadas en el meristemo sufren un proceso de diferenciación para transformarse en diferentes tipos celulares que experimentarán una serie de cambios progresivos hasta convertirse en una célula especializada. Después del crecimiento del embrión en la semilla, la formación de nuevas células queda casi restringida al meristemo: tejidos permanentemente jóvenes, cuyas células se dividen por mitosis. Por tanto, el cuerpo de los vegetales está constituido por dos tipos de tejidos: meristemo o tejidos embrionarios (derivados del embrión) y tejidos adultos.

Por último, al considerar los niveles de organización de un vegetal podemos identificar: Vegetal--> Órganos --> Sistemas de tejidos --> tejidos --> células. Los sistemas de tejidos son grupos de tejidos que presentan continuidad en todo el vegetal y son tres: (i) el sistema fundamental: formado por parénquima, tejido de relleno, y colénquima/esclerénquima como tejidos de sostén; (ii) el sistema epidérmico: constituido por la epidermis, cubierta protectora y más tarde, por la peridermis en el cuerpo secundario y (iii) el sistema vascular: compuesto por xilema y floema. 


\section{TRANSPORTE INTRACELULAR DE MACROMOLÉCULAS}

8.1 Ruta secretora y endocítica: conceptos básicos. Las células eucarióticas superiores han desarrollado un sistema de membranas endógeno que les permite tanto captar las macromoléculas del exterior como liberarlas del interior celular. Este tráfico de macromoléculas está muy organizado en ambos sentidos constituyendo: (i) la vía secretora que va hacia el exterior, básicamente, desde el retículo endoplásmico (RE) pasando por el aparato de Golgi (AG) a la superficie celular, con una ruta lateral que va a los lisosomas/vacuolas (revisado en Hanton et al., 2005; Matheson et al., 2006) y (ii) la vía endocítica que va hacia el interior, desde la membrana plasmática a los endosomas y lisosomas/vacuolas (revisado en Aniento y Robinson, 2005; Robinson et al., 2007). Ambas rutas no son totalmente independientes puesto que llegan a interconectarse a diferentes niveles (Figura 7).

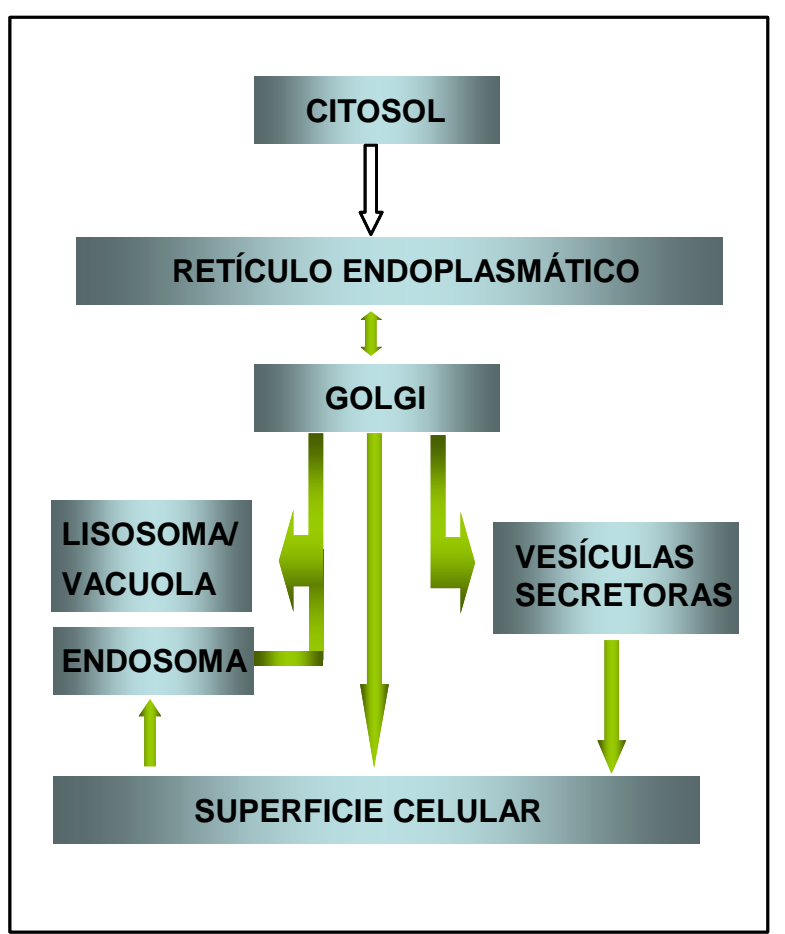

Figura 7. Las rutas secretora y endocítica. El esquema representa el tráfico de macromoléculas sintetizadas en el interior de la célula. Las flechas coloreadas marcan tanto la ruta secretora como endocítica.

Funcionalmente, el sistema de endomembranas de plantas es similar al de levaduras o animales e incluye la síntesis y transporte de moléculas de la ruta secretora a sus destinos finales. Sin embargo, estructuralmente, el de plantas presenta una serie de peculiaridades que necesitan ser descritas: (i) no existe un compartimiento intermedio entre RE-AG (Neumann et al., 2003), conocido en mamíferos como ERGIC (Endoplasmic reticulum-golgi intermediate compartment); (ii) el aparato de Golgi forma numerosas vesículas dispuestas por el citosol y capaces de moverse a gran velocidad a través de la red de los microfilamentos de actinamiosina con independencia del citoesqueleto (Boevink et al., 1998; Nebenführ et al., 1999; Brandizzi et al., 2002); (iii) estas vesículas del aparato de Golgi podrían interaccionar 
directamente con el retículo endoplásmico para el intercambio de moléculas cargo en los dominios denominados ERES (Endoplasmic Reticulum Export Sites) (Yang et al., 2005) y (iv) las plantas presentan uno o más compartimentos, de gran tamaño y con diferentes funciones, llamados vacuolas, destacando su función en la degradación de proteínas acometida por la vacuola lítica y la de almacenamiento (Hanton et al., 2006). Por su parte, en mamíferos, no existen las vacuolas y la degradación proteica es desarrollada en los lisosomas, no existentes en plantas, que aparecen en forma de pequeñas y numerosas vesículas distribuidas por toda la célula.

Así, el aparato de Golgi actúa como la mayor estación de intercambio de macromoléculas en células vegetales (revisado en Jurgens, 2004), estando involucrado en el tráfico desde el RE a los diferentes tipos de vacuolas o a la membrana plasmática (ver Figura 8). Además, recientemente se ha descrito la implicación del AG en el transporte de proteínas a orgánulos no convencionales de la ruta secretora, como el cloroplasto y los peroxisomas. Sin embargo, en estos casos, la ruta de importación de proteínas directamente desde el citosol es mayoritaria y está mejor caracterizada (Baker y Sparkes, 2005; Gutensohn et al., 2006). El aparato de Golgi está formado por una serie de cisternas limitadas por una membrana y de forma aplanada que se conocen como dictiosomas de Golgi. El número de los mismos por célula varía enormemente según el tipo celular: algunas células animales tienen un gran dictiosoma, mientras que en las células vegetales cada vesícula se corresponde con uno de ellos. Por tanto, en este caso los dictiosomas se presentan a cientos y con un tamaño muy pequeño (revisado en Hawes y Satiat-Jeunemaitre, 2005). Además, una multitud de vesículas de tamaño más reducido se hallan asociadas a los dictiosomas. Éstas son vesículas de transporte de proteínas que se desplazan hacia, entre y desde las cisternas de un mismo dictiosoma. Así pues, el aparato de Golgi presenta una estructura polarizada donde las proteínas entran por la red del cis Golgi en vesículas de transporte que provienen del RE (revisado en Hanton et al., 2005; Hanton et al., 2006; Matheson et al., 2006) y salen en vesículas diferentes por la red del trans Golgi hacía la superficie u otros orgánulos (revisado en Hanton et al., 2007). Estas dos redes son importantes en la clasificación de las proteínas: las que entran en la red cis pueden seguir a través del aparato de Golgi o volver al RE (transporte anterógrado o retrógrado, respectivamente); las que salen de la red del trans Golgi son clasificadas según su destino sea los lisosomas/vacuolas, las vesículas de secreción o la superficie celular (revisado en Hawes y Satiat-Jeunemaitre, 2005; Hanton et al., 2007). Más aún, durante el paso a través del aparato de Golgi, las moléculas transportadas pueden sufrir modificaciones covalentes ordenadas, como la glucosilación (revisado en Scheiffele y Fullekrug, 2000).

Las proteínas sintetizadas de novo entran en la ruta biosintética-secretora cuando atraviesan la membrana del RE desde el citosol o el RE rugoso. Las vesículas destinadas al aparato de Golgi emergen desde las regiones especializadas del RE llamadas ERES (revisado en Hanton et al., 2005; Matheson et al., 2006) cuya membrana no tiene ribosomas adheridos y 
se encuentra a menudo entre el RE rugoso y el aparato de Golgi. Estas vesículas pueden transportar cualquier proteína que esté correctamente plegada desde el RE al aparato de Golgi (Phillipson et al., 2001). La salida de proteínas solubles desde este orgánulo parece no estar determinada por ningún receptor específico. Sin embargo, para algunas proteínas de membrana se ha puesto de manifiesto que interacciones entre componentes de la cubierta de las vesículas y éstas determinan su transporte específico. En este sentido, se han descrito motivos dibásicos y diacídicos como señales de salida selectiva de proteínas de membrana desde el RE (Giraundo y Marconi, 2003; Hanton et al., 2005), Por otro lado, se ha demostrado que proteínas de unión a membrana y solubles destinadas al RE pueden mantener su localización mediante un transporte cíclico entre éste y la red del cis Golgi (Denecke et al., 1990; Denecke et al., 1992; Saint-Jore et al., 2002; revisado en Hanton et al., 2005). En este caso, el transporte retrógrado desde el aparato de Golgi al RE de proteínas solubles tiene lugar a través la señal $\mathrm{H} / \mathrm{KDEL}$ del dominio $\mathrm{C}$ terminal, reconocida por el receptor defectivo de retención en RE 2 (ER retention defective 2, ERD2) (Denecke et al., 1992). Las proteínas

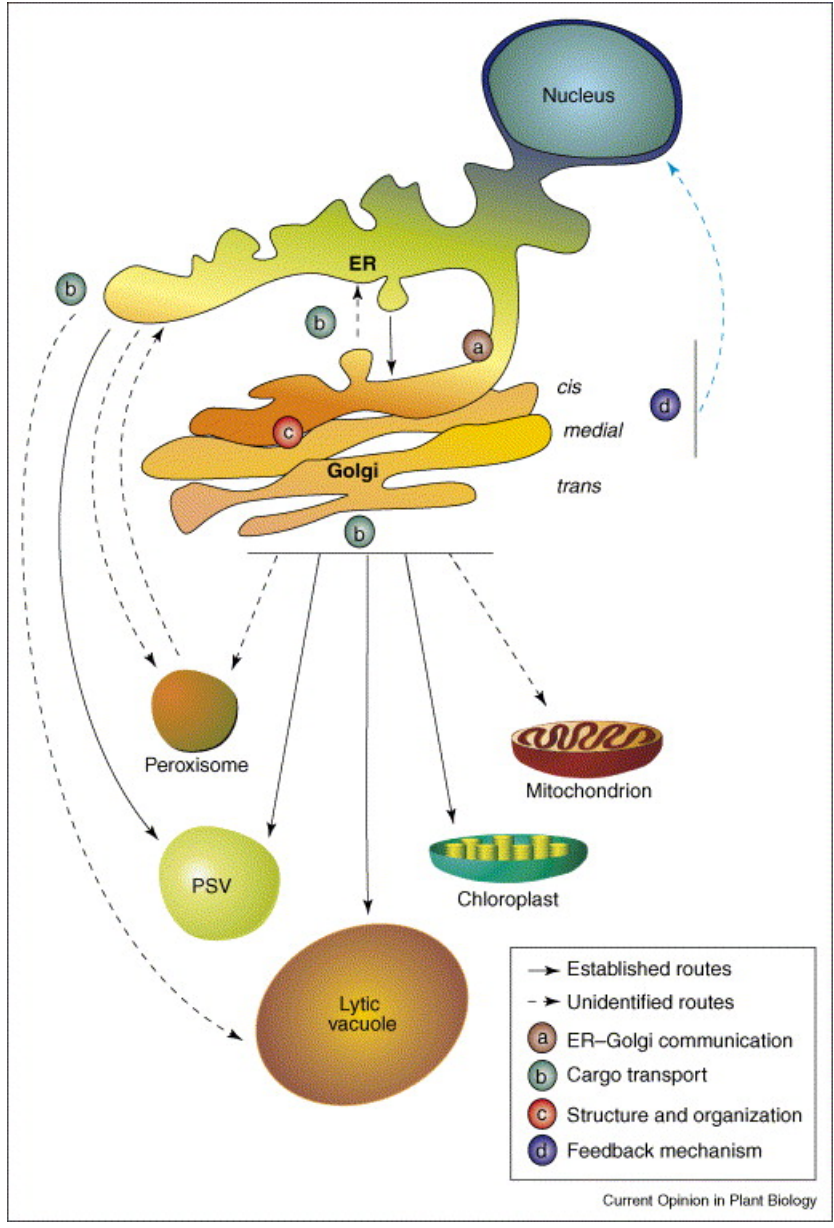

Figura 8. Representación esquemática de la ruta secretora de plantas: tráfico vesicular entre compartimentos celulares. Dada las características singulares de esta ruta en plantas, numerosas cuestiones son actualmente objeto de debate: (a) La relación entre los ERES y las vesículas de Golgi. (b) Potenciales y establecidas rutas de transporte desde Golgi, incluida a la mitocondria. (c) Cómo RE y AG interaccionan manteniendo su identidad como orgánulos diferentes. (d) Posible mecanismo de retroalimentación de la ruta secretora. (Matheson et al., 2006. Current Opinión in Plant Biology. 9, 601-609).

transmembrana son seleccionadas para el transporte al RE por un motivo de dos lisinas en el extremo C terminal citosólico, a través del cual interaccionan con el factor ARF1 y otros componentes de las vesículas del coatómero COPI (ver más adelante) (Contreras et al., 2004a). 
En principio, se asume que las proteínas transmembrana son exportadas del RE por un mecanismo similar al de las proteínas solubles, siguiendo un flujo pasivo. En este caso, su destino viene dictado por la longitud de su dominio hidrofóbico y el aumento en el espesor de las membranas que constituyen el RE, el AG y la membrana plasmática (Andreeva et al., 2000; Phillipson et al., 2001; Brandizzi et al., 2002; daSilva et al., 2004). Sin embargo, como se ha mencionado antes, pueden existir determinadas señales en el domino citosólico de las proteínas transmembranas que modifiquen el destino dictado por el fragmento hidrofóbico (Hanton et al., 2005).

Después del paso por la red del trans Golgi, las proteínas pueden ser transportadas a las vacuolas o a la membrana plasmática (revisado en Hanton et al., 2007). Si no poseen señales específicas las proteínas son transportadas directamente a la superficie de la célula, sin especificar un dominio concreto de la misma, mediante una ruta por defecto no selectiva y constitutiva (revisado en Hanton et al., 2007). Sin embargo, las proteínas destinadas a las vacuolas son seleccionadas mediante secuencias específicas para su empaquetamiento en vesículas de transporte recubiertas de clatrina (ver más adelante). Asimismo, las vesículas de secreción liberan las proteínas que transportan al exterior celular, normalmente, en respuesta a una señal extracelular (Happel et al., 2004). Cabe destacar que se ha descrito la existencia de rutas de transporte de proteínas directamente desde el RE hacia vesículas de lisis y de almacenamiento, o a peroxisomas (Matheson et al., 2006), sin mediar el aparato de Golgi, hecho que podría explicar que el mismo, a pesar de su importancia en la ruta secretora, no es vital para la célula al menos en periodos de inhibición cortos.

8.2 Mecanismos moleculares del transporte vesicular. La célula posee al menos 10 compartimentos limitados por membrana, químicamente distintos e interconectados mediante el transporte vesicular. Los marcadores que guían la dirección de las mismas están expuestos en la superficie citosólica de las membranas de las vesículas que aseguran que sólo se fusionen con el compartimiento adecuado y dictan, por lo tanto, el patrón de tráfico entre ellos.

Generalmente, la mayoría de vesículas de transporte se forman a partir de regiones especializadas de membrana revestidas por una red de proteínas. Las mejor caracterizadas, son las revestidas por clatrina y las de coatómero. Las primeras participan en el transporte selectivo mediado por receptores hacia la vacuola y las segundas intervienen en el transporte entre el RE y el aparato de Golgi, entre las cisternas que constituyen cada dictiosoma de Golgi y en el transporte vesicular no selectivo o ruta por defecto desde la red del trans Golgi a la membrana plasmática.

8.2.1 El transporte anterógrado. Las proteínas se mueven desde el RE hacia el aparato de Golgi vía el transporte anterógrado. Éste depende de un complejo proteico denominado COPII (coat protein*, COP) que se da desde áreas especializadas conocidas como sitios de exportación del RE, ERES (ER export sites). El complejo COPII incluye tres componentes citosólicos: una pequeña GTPasa (SAR1) y dos pequeños heterodímeros estructurales

* Nota: no confundir con la proteína de cubierta viral que tiene la misma denominación en inglés que la proteína 44 del coatómero 
Sec23/24 y Sec 13/31. En síntesis, el tráfico anterógrado de proteínas implica la exportación desde el RE dependiente de vesículas SAR1/COPII y la fusión con la red del cis Golgi mediada por Rab1 (Jurgens, 2004).

Los mecanismos utilizados para la salida de proteínas desde el RE hacia el AG han suscitado un gran interés recientemente. Hay que recordar en este aspecto la peculiaridad de la célula vegetal consistente en la ausencia de un compartimento intermedio entre los dictiosomas que constituyen el AG y el RE. Se han propuesto diferentes modelos para explicar la dinámica del proceso basados todos ellos en evidencias experimentales : (i) en el modelo "vacuum cleaner", los dictiosomas se mueven por la superficie del RE recogiendo las vesículas COPII con las proteínas a transportar, por lo que toda la superficie del RE sería capaz de exportar proteínas (Figura 9A); (ii) en el modelo "stop-and-go", los dictiosomas reciben la carga de sitios de exportación definidos, ERES, que emiten señales específicas que provocan la parada momentánea de éste (Figura 9B); (iii) en un tercer modelo tanto los ERES como los dictiosomas formarían unidades secretoras móviles, permitiendo un intercambio continuo entre ambos orgánulos (Figura 9C) y (iv) por último, un cuarto modelo ("kiss-and-run”) implicaría la interacción de un dictiosoma con varios ERES a la vez de forma no permanente y en continuo cambio en cuanto al número de ERES implicados y su posición (Hanton et al., 2005; Hanton et al., 2006).

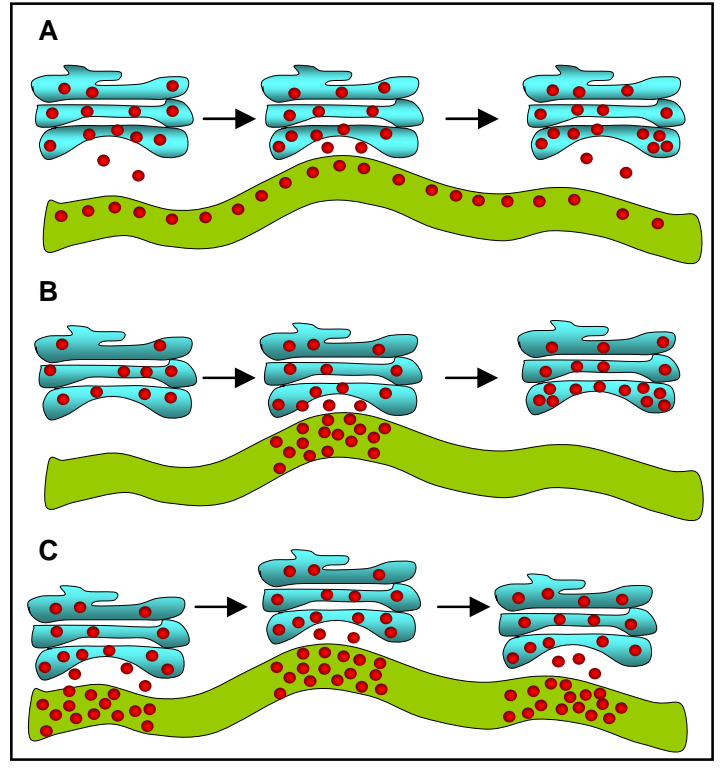

Figura 9. Modelos propuestos para el transporte de proteínas entre los sitios de exportación del RE (ERES) y los dictiosomas del aparato de Golgi. Los dictiosomas del aparato de Golgi se mueven a lo largo de la superficie del RE y éste: es capaz de exportar proteínas a lo largo de toda su superficie (A) sólo en determinados sitios fijos, ERES, que lanzan señales específicas de parada (B) o en ERES que, como las partículas de Golgi, son móviles (C) (Hanton et al., 2005. Traffic. 6: 267-277).

8.2.2 El transporte retrógrado. En el transporte retrógrado, las proteínas se mueven desde el aparato de Golgi al RE y está mediado por el complejo I (COPI) compuesto de una pequeña GTPasa (ARF1) y un complejo heptamérico de proteínas de cubierta (Matheson et al., 2006). Al contrario de lo que ocurre en las cubiertas de clatrina, las de coatómeros no se autoensamblan, sino que necesitan energía en forma de ATP que dirija su formación. Tanto el ensamblaje como el desensamblaje del revestimiento de coatómero dependen de una proteína, denominada 
ARF1, y definida como una GTPasa monomérica con una cola anfipática constituida por un ácido graso. En el citosol, esta proteína, se encuentra altamente concentrada de forma inactiva al estar unida a una molécula de GDP. Asimismo, la membrana dadora de las vesículas que se van a revestir de coatómero contiene un factor proteico de intercambio de nucleótidos de guanina (Guanine exhange factor, GEF) que al unirse ARF1, ésta libera su GDP y se activa uniendo GTP en su lugar. La unión de GTP provoca que ARF1 exponga la cola de ácido graso que se inserta en la bicapa lipídica de la membrana dadora (ver Figura 10A). Esta inserción recluta a las moléculas del coatómero que se unen a ARF1. Asimismo, el coatómero también se une a proteínas de la familia p24, lo que pone de manifiesto un sitio de unión dual para el coatómero (Contreras et al., 2004b; Robinson et al., 2007). Como consecuencia, el ensamblaje de la cubierta del coatómero estira de la membrana, induciendo la formación de una yema, lo que facilita que se desprenda como una vesícula revestida (ver Figura 10B). Por último, cuando la vesícula alcanza la membrana de destino, una proteína activadora de GTPasa hidroliza el GTP de ARF1. Esto provoca un cambio conformacional por el que el ácido graso se desprende de la membrana y con ello todo el revestimiento, permitiendo que la membrana de la vesícula se fusione con la del compartimiento de destino.
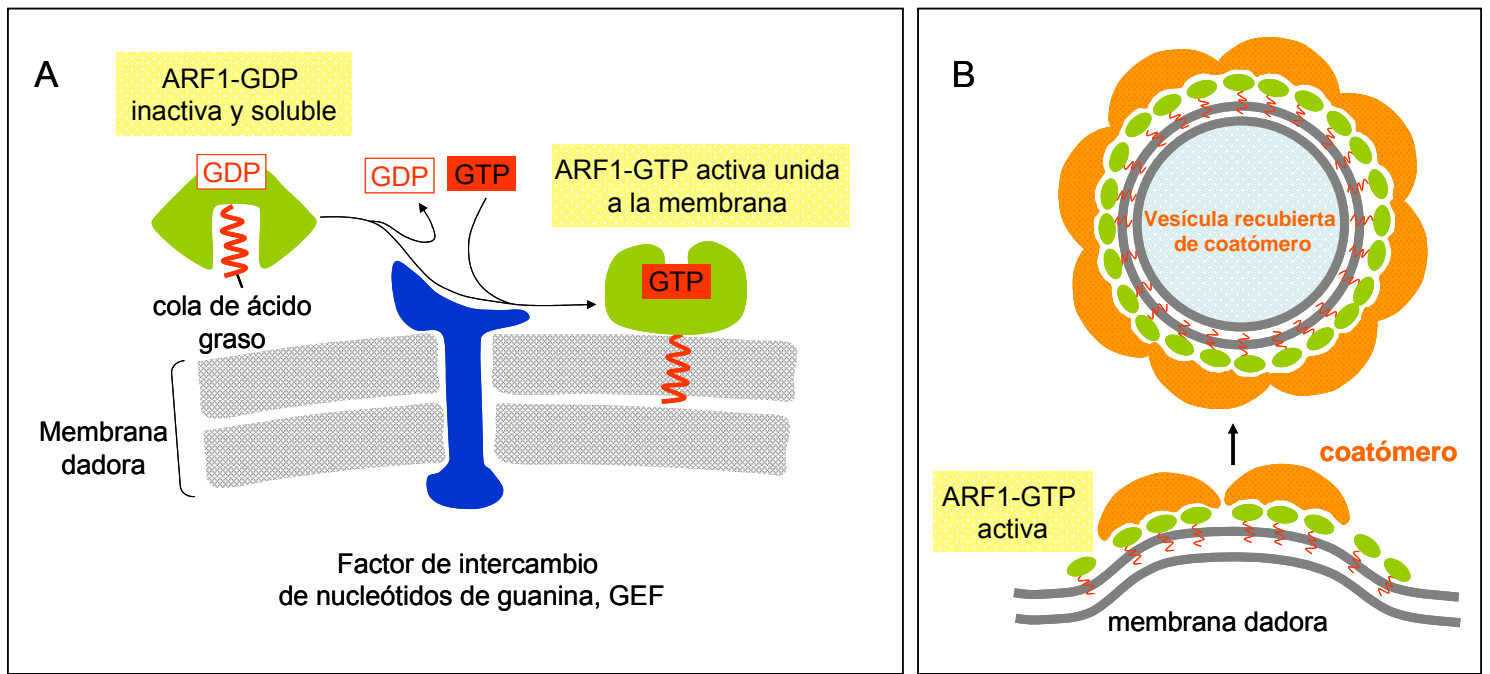

Figura 10. Modelo sobre la formación de vesículas revestidas de coatómero (COPI). (A) La proteína ARF1-GDP se une al factor de intercambio de nucleótidos de guanina (GEF), lo que provoca un cambio conformacional que permite que ésta se inserte en la membrana. (B) La proteína ARF1 activa, recluta las moléculas del coatómero en la formación de la vesícula revestida. (Adaptado de Alberts et al., 1996).

8.2.3 Papel de las GTPasas en la fusión a membrana de vesículas. Las vesículas han de ser altamente específicas en cuanto a su membrana diana. Deben, por lo tanto, expresar marcadores de superficie que les identifiquen. Se ha propuesto la participación de las proteínas SNARE (soluble N-ethylmaleimide sensitive factor attachment protein receptors, revisado en Hong, 2005) en este proceso, de las cuales diferenciamos las v-SNARE, en la membrana de la vesícula y las t-SNARE, en la membrana diana. El proceso clave de reconocimiento está controlado por una familia de proteínas GTPasas monoméricas llamadas proteínas Rab. Estas 
proteínas son las responsables de que la interacción entre v-SNARE y t-SNARE sea la correcta. Las proteínas Rab son proteínas citosólicas de aproximadamente $23 \mathrm{kDa}$ que, alternando entre sus formas GDP y GTP, ayudan a reclutar un número de moléculas efectoras en la superficie de determinadas membranas.

La proteína Rab está unida a las vesículas revestidas y cuando las mismas encuentran la membrana diana, la unión v-SNARE y t-SNARE permite que Rab hidrolice el GTP que lleva unido, preparando la fusión entre ambas membranas. La primera proteína Rab fue descubierta en levaduras y fue llamada Sec4. Su nombre se debe a que fue hallada por mutaciones que interfieren en el proceso de secreción (conocidas como mutaciones Sec). La especificidad de los procesos de fusión de vesículas viene en primer lugar determinada por las proteínas Rab, que reclutan factores que permiten la aproximación específica de las vesículas a la membrana diana (ver más adelante). Además, la fusión de membrana está catalizada por otras proteínas citosólicas, incluyendo las proteínas de fusión sensibles a $\mathrm{N}$-etilmaleimida, NSF ( $\mathrm{N}$ ethylmaleimide-sensitive fusion protein) y las proteínas solubles de acoplamiento a NSF, SNAP (soluble NSF attachment protein), que se unen entre si formando un complejo de fusión en el lugar de anclaje.

\subsubsection{Inhibición del transporte entre el retículo endoplasmático y el aparato de Golgi. La} inhibición de la función de COPI, además de bloquear el transporte RE-AG da lugar a una disfunción de los ERES, cuya formación es dependiente de un transporte retrógrado activo (Hanton et al., 2006). Se postula que algún miembro de COPI pudiera tener a su vez participación, directa o indirecta, en el transporte anterógrado (Hanton et al., 2006). El transporte activo mediado por COPI es pues necesario para la integridad de los ERES y, como consecuencia, para el transporte de proteínas. Además, la integridad del aparato de Golgi, a su vez, se verá modificada por el tráfico de membranas desde y hacia el RE. En plantas, el tratamiento con el metabolito fúngico Brefeldina $\mathbf{A}$, inhibe la ruta de secreción y el transporte a la vacuola de proteínas. La diana de esta droga en plantas es un factor de intercambio de nucleótidos de guanina (GEF) que, como se ha indicado antes, es el encargado de catalizar la activación de la GTPasa ARF1, que participa directamente en el reclutamiento de las moléculas de coatómeros durante el recubrimiento de las vesículas COPI (Nebenführ et al., 2002). Ambas, GEF y ARF1, se localizan en el aparato de Golgi. Por ello, el primer efecto caracterizado de la droga es la pérdida de los complejos COPI del aparato de Golgi. A mayor exposición, se producen cambios secuenciales en la arquitectura de Golgi, pérdida de las vesículas y colapso, formando un compartimiento híbrido RE-AG. Todo ello produce, a su vez, un bloqueo en el transporte anterógrado, probablemente como resultado de la inhabilitación de vesículas del ER para fusionarse con vesículas de Golgi anormales, pero no porque la droga tenga efecto directo sobre la exportación desde el RE. Exposiciones más prolongadas provocan la transformación del compartimiento híbrido RE-Golgi en una estructura aberrante con características estructurales que difieren del RE normal (Ritzenthaler et al., 2002). 
8.2.5 Componentes de la matriz proteica del aparato de Golgi. Los componentes proteicos de la matriz del aparato de Golgi, conocidos como golginas, interaccionan con las membranas de este orgánulo de múltiples formas que quedan ilustradas en la figura 11. Esta diversidad es reflejo de las diferentes funciones llevadas a cabo por este tipo de proteínas a las que se les asigna un papel estructural en la unión entre las diferentes cisternas que forman cada dictiosoma durante su génesis, además de servir como ancla de las vesículas transportadoras para favorecer el acercamiento y la fusión de las membranas. Las golginas presentan un motivo central desestructurado que puede formar una estructura en varilla y dos dominios funcionales $\mathrm{N}$ terminal y $\mathrm{C}$ terminal. Algunas de ellas son proteínas integrales de membrana que se reciclan entre el aparato de Golgi y el RE. Sin embargo, debido a que el AG es un copartimento celular extremadamente dinámico, consecuencia del incesante tránsito de proteínas y membranas, muchas de estas golginas se asocian de forma periférica tras interaccionar con pequeñas GTPasas, como las proteínas Rab. Este tipo de interacción permite el rápido reciclaje desde una membrana del AG a otra a través del citoplasma, puesto que estas GTPasas son capaces de localizarse en el citosol o unidas a las membranas mediante un proceso controlado por el estado de fosforilación de los nucleótidos de guanina asociados, mecanismo a su vez regulado por los factores GAPs (GTPase activating protein) y GEFs. Las proteínas Rab unidas a la membrana y por tanto en su forma activa, unida a GTP, son capaces de reclutar las golginas a la membrana del aparato de Golgi actuando como receptores específicos. En este tipo de interacciones cabe destacar que la proteína Rab6 y las golginas Bicaudal-D1 y -D2 son importantes en el reclutamiento específico de la dinactina. Este complejo proteico es el receptor/adaptador de la dineina que, junto la kinesina, constituye la proteína motora más importante de los microtúbulos en animales (Matanis et al., 2002; Short et al., 2002). Por tanto, el citoesqueleto también participa en el mantenimiento de la estructura del aparato de Golgi, así como en la formación y movimiento de las vesículas de transporte relacionadas con este orgánulo (Allan et al., 2002).

Como hemos visto, las proteínas Rab están implicadas en casi todos los estados del transporte de vesículas, desde la formación de las vesículas a su movilidad, así como en su fusión (Zerial y McBride, 2001). Diferentes miembros de la familia de proteínas Rab son capaces de marcar compartimentos de membranas del interior de la célula, de tal manera que muchas proteínas Rab se localizan en sub-dominios específicos del aparato de Golgi. Una vez la proteína Rab se activa, Rab-GTP, y por tanto se localiza en la membrana, ésta es capaz de reclutar moléculas efectoras del citoplasma o de otras membranas, mediante interacciones proteína-proteína o proteína-lípido que delimitan un dominio específico de la membrana (Pfeffer, 2001; Pfeffer, 2003). En el aparato de Golgi, estas moléculas efectoras vienen representadas en gran parte por la familia de las golginas (Barr y Short, 2003; Short et al., 2005). La participación de las proteínas Rab en todas las etapas del transporte vesicular, sugiere que las vesículas del interior celular pueden ser caracterizadas como subdominios de membrana organizados por proteínas Rab que, durante su tiempo de vida media, son capaces de 
separarse físicamente de una membrana para unirse a otra. Sin embargo, las proteínas Rab no son la únicas pequeñas GTPasas conocidas que regulan los componentes de la matriz del aparato de Golgi. La familia de las proteínas ARL o GTPasa relacionadas con ARF, de las cuales se han descrito hasta diez miembros en humanos, tienen diversas funciones in vivo. Actualmente, sólo dos miembros de la familia, ARL1 y ARL3/ARFRP1, se han caracterizado por ser importantes en la estructura y función del aparato de Golgi. Resultados recientes muestran que a través de una cascada de interacciones proteína-proteína en la que se ven involucradas las GTPasas, la ARL1 recluta golginas que presentan un dominio conocido como GRIP (llamado así por las iniciales de las primeras cuatro proteínas de animales en las que se encontró: golgin-97, RanBP2a, Imh1p y p230/golgin-245) a la red trans del aparato de Golgi, estando este mecanismo conservado evolutivamente (Panic et al., 2003a; Panic et al., 2003b; Wu et al., 2004). De forma similar, existen otro tipo de golginas con un dominio carboxilo terminal denominado GRAB (GRIP-related ARF-binding) capaz de interaccionar con GTPasas de la familia ARF/ARL (Short et al., 2005).

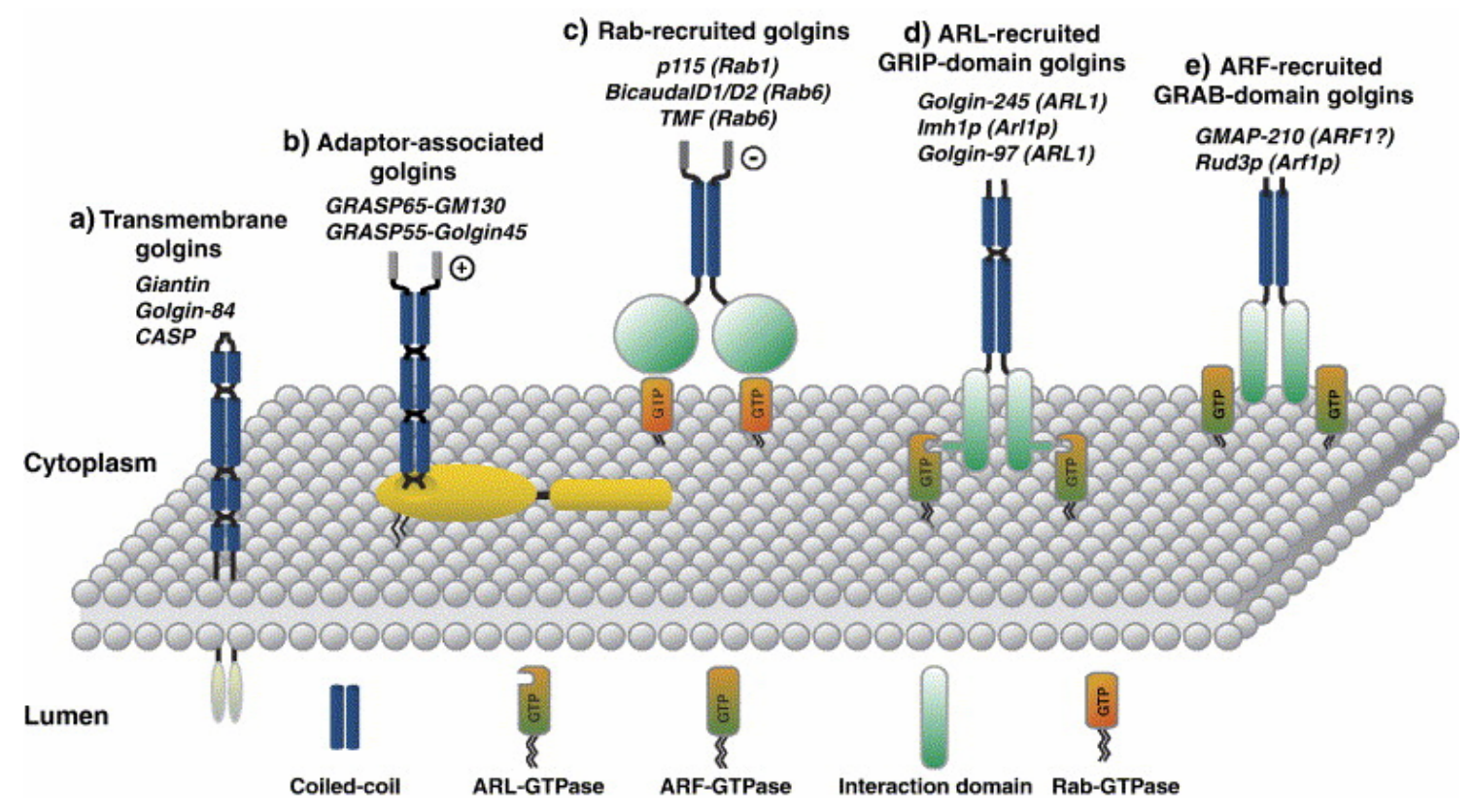

Figura 11. Formas de asociación de las golginas a la membrana del aparato de Golgi. Algunas presentan un dominio transmembrana cerca del extremo $\mathrm{C}$ terminal (a), mientras que otras son proteínas asociadas a la periferia de las membranas (b-e). Las golginas periféricas pueden estar asociadas a la membrana por una interacción con proteínas de la familia GRASP, dirigidas a su vez por su extremo $\mathrm{N}$ terminal a la membrana (b). Otras golginas se localizan en la membrana dirigidas por pequeñas GTPasas de las familias Rab (c), ARL (d) y ARF (e). Las proteínas Rabs se dirigen a las membranas mediante modificaciones en el $\mathrm{C}$ terminal, mientras que es el $\mathrm{N}$ terminal el que será modificado en las ARFs y la mayoría de las ARLs. La forma de interacción entre golginas y Rabs es desconocida, mientras que ARL1 une a un dominio GRIP conservado presente en algunas golginas. Esta interacción es dependiente de un residuo de tirosina conservado y presente en ARL1. De forma análoga, el dominio GRAB podría unir a ARF1 (Short et al., 2005. Biochim Biophys Acta. 1744, 383-395). 
Otro componente importante de la matriz del aparato de Golgi capaz de interaccionar con las golginas son las proteínas GRASP (Golgi reassembly stacking protein), con pesos moleculares de 55 y $65 \mathrm{KDa}$, presentan un grupo miristoilo en su extremo amino terminal mediante el cual se anclan a la membrana. Ambas proteínas se fosforilan durante la mitosis, lo que puede ser importante durante el desensamblaje del aparato de Golgi en este proceso y en el posterior apilamiento de las cisternas para constituir los nuevos dictiosomas. Esta regulación estructural de las proteínas GRASP se realiza, probablemente, durante su interacción con miembros de la familia de las golginas (GRASP65-GM130 y GRASP55-golgin45). Además, las proteínas GRASP son importantes en la funcionalidad del aparato de Golgi ya que también actuan de puente entre la matriz del AG y determinadas proteínas integrales de membrana que son transportadas.
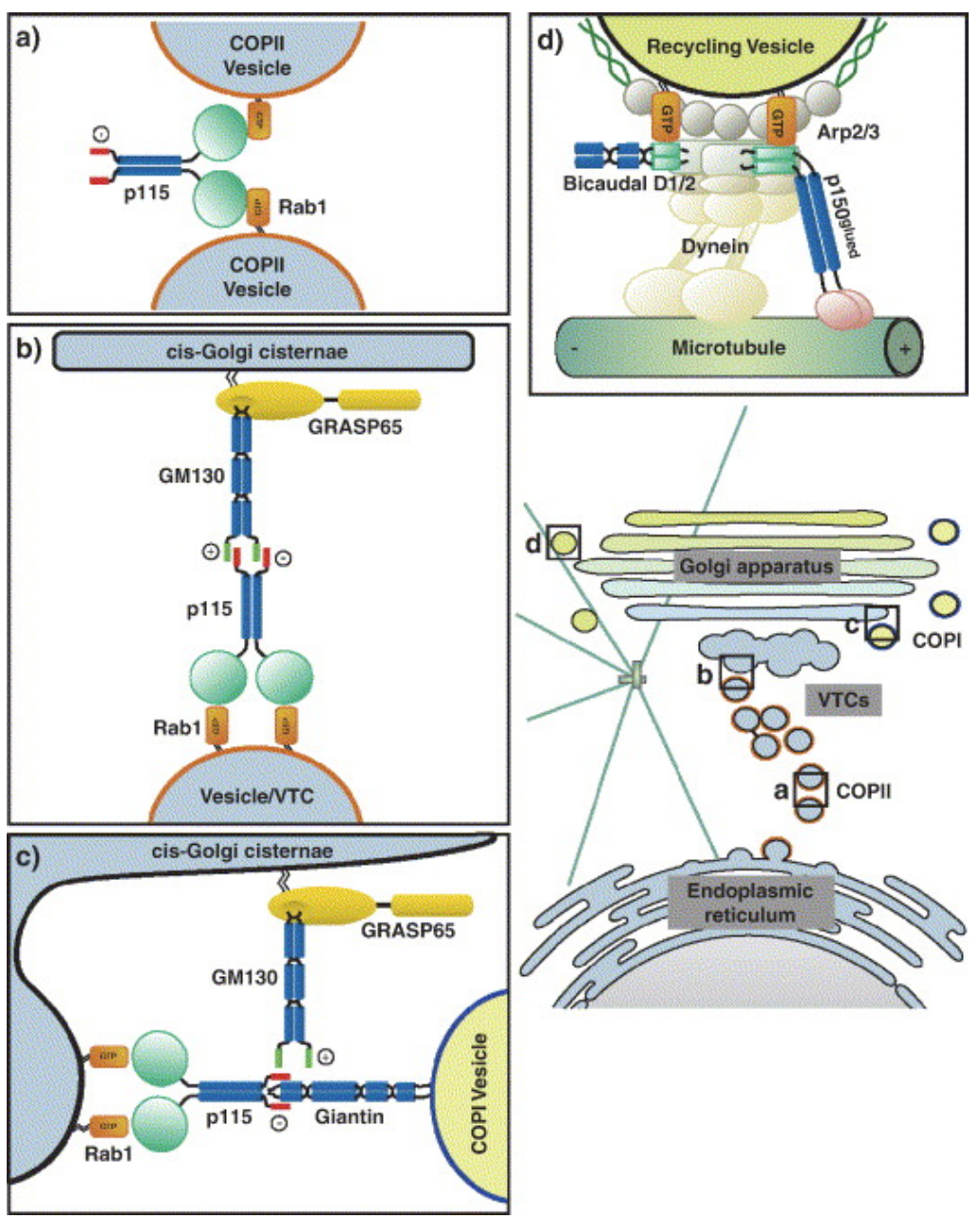

Figura 12. Sistemas de anclaje a membranas del aparato de Golgi. El papel de p115 en el sistema de anclaje del tráfico desde RE al aparato de Golgi y a través de éste. (Short et al., 2005. Biochim Biophys Acta. 1744, 383-95)

El conocimiento actual sobre las bases moleculares que controlan el transporte vesicular en el interior celular se encuentra aún en un estado incipiente. Sin embargo, algunos factores implicados en este proceso han sido caracterizados estructuralmente y su función especifica 
descrita. Por ejemplo, en animales, las vesículas COPII formadas a partir de los ERES se agrupan por medio de una golgina conocida como factor p115 siendo Rab 1 el encargado de reclutarlo (Figura 12a). Estas vesículas se fusionan por medio de un mecanismo dependiente de factores del tipo NSF y SNARE para formar un compartimento intermedio o VTC. Este compartimento se ancla en la cara cis del aparato de Golgi, mediante la interacción entre los complejos p115-Rab1 del VTC, y GM130-GRASP65 de la cara cis del aparato de Golgi (Figura 12b). Ambos complejos, también pueden tener un papel adicional en el anclaje de las vesículas COPI a la cara cis del aparato de Golgi mediante la interacción con una golgina transmembrana conocida como Giantina que se localiza en las vesículas COPI (Figura 12c). En la cara trans del aparato de Golgi se produce el reclutamiento del complejo motor de los microtúbulos dineina-dinactina a las vesículas de transporte mediante multiples interacciones con el complejo Rab6 y las golginas Bicaudal-D1 y -D2. De esta forma las vesículas de transporte se anclarían a los microtúbulos y los motores de dinactina/dineina las transportarían a través del citoesqueleto (Figura 12d).

\section{INTERACCIONES RNA-PROTEÍNA}

Las interacciones RNA-proteína forman parte de numerosos procesos celulares, así como de la biología de los virus. La capacidad de unión a RNA de determinadas proteínas ha sido ampliamente descrita y se ha demostrado su papel esencial en la estabilización, la protección, el empaquetamiento y el transporte de estos ácidos nucleicos.

Basándose en el análisis estadístico de 45 complejos de RNA/proteína cristalizados (Treger y Westhof, 2001), se definieron tres grupos: los de las tRNA sintasas, los ribosomales y un tercero que incluye varias clases de complejos. Además, el estudio anterior permitió establecer algunos aspectos generales relacionados con este tipo de interacciones, siendo las principales conclusiones las siguientes: (i) los aminoácidos situados en la zona de unión RNA/proteína más frecuentes (Arg, Asn, Ser, Lys) así como los menos frecuentes (Ala, lle, Leu, Val) coinciden en los tres grupos, además, los residuos de Trp y Cys fueron poco frecuentes en todos los casos; (ii) los porcentajes de aminoácidos localizados en esta misma interfase, según sus propiedades fisicoquímicas fueron un $40 \%$ cargados (32\% positivos y $8 \%$ negativos), un $30 \%$ polares, un $22 \%$ hidrofóbicos y finalmente, un $8 \%$ que se correspondió exclusivamente con el aminoácido Gly; (iii) en los complejos ribosomales se da una mayor preferencia por las interacciones a través del fosfato que por las de las ribosas y éstas frente a las bases y (iv) en el resto de complejos se observaron algunas relaciones de preferencia en las interacciones, Arg y Lys escogen el fosfato frente a la ribosa o las bases; Pro y Asn optan por las bases y por último, Met, Phe y Tyr eligen las ribosas. Por otra parte, lle, Pro y Ser prefieren unir a Adenina, Leu a Citosina, Asp y Gly a Guanina y Asn a Uracilo. Respecto al tipo de unión establecida: (i) el $72 \%$ son interacciones de van der Waals y el $23 \%$ forman puentes de hidrógeno; (ii) de estos últimos, el $54 \%$ son puentes de hidrógeno estándar, el $33 \%$ son del tipo $\mathrm{C}-\mathrm{H}$ y el $13 \%$ restante son iónicos; (iii) las bases están implicadas en el $38 \%$ de los puentes de hidrogeno y 
más de un $26 \%$ de dichos puentes reciben el $\mathrm{H}$ del RNA; (iv) el átomo de oxígeno del grupo 2'hidroxilo de las ribosas está implicado en el $21 \%$ de los puentes de hidrógeno y (v) los aminoácidos que menos frecuentemente interaccionan con el RNA contactan a través de moléculas de $\mathrm{H}_{2} \mathrm{O}$, mientras que los de mayor frecuencia, a excepción de la Ser, lo hacen directamente.

Las proteínas de unión a RNA, en la mayoría de los casos, reconocen estructuras secundarias del mismo en forma de lazos $u$ horquillas en un proceso que ocasiona cambios conformacionales en ambas macromoléculas. A pesar de que in vitro dichas interacciones parecen inespecíficas de secuencia, in vivo son altamente específicas debido sobre todo a este reconocimiento estructural (Wagner et al., 2001). Sin embargo, esta especificidad de unión también puede ser debida a la presencia de otros factores proteicos 0 a la compartimentalización estructural en el interior celular que favorece la proximidad entre la proteína y una molécula de RNA determinada.

El análisis comparado de secuencias de proteínas con capacidad de interacción con el RNA ha permitido la identificación de dominios de unión a RNA o RBDs (de RNA Binding Domain) y, entre ellos, los mejor descritos son el motivo de reconocimiento de RNA o RRM (de RNA Recognition Motif), el dominio de unión a RNA doble cadena o dsRBD (de double strand RNA Binding Domain) y el dominio $\mathrm{KH}$. Además, en las interacciones con hebras de RNA de simple cadena (single strand RNA, ssRNA), muy frecuentes en el caso de virus de plantas, se ha definido un RBD canónico $\alpha / \beta$ compacto y globular, con 4 hojas $\beta$ empaquetadas y $2 \alpha$ hélices (Hall, 2002). Sin embargo, con los últimos estudios de varios complejos ssRNA/proteína mediante cristalografía de rayos $X$ y resonancia magnética nuclear $(R M N)$ se ha descrito la presencia de diferentes RBDs, lo cual ha planteado una amplia diversidad de mecanismos de unión. En muchas ocasiones, los dominios de unión a RNA pueden estar localizados en pequeñas regiones que en general son altamente básicas por ser ricas en Arg. Éstas son capaces de unir RNA cuando son sintetizadas in vitro como péptidos aislados en ausencia del resto de la proteína. En algunos casos, la especificidad es tan elevada que estos péptidos pueden presentar las mismas propiedades cinéticas que la proteína entera en el proceso de unión

En plantas, se han descrito las interacciones RNA-proteínas en procesos tales como: (i) la regulación de la estabilidad y la traducción de los mRNA cloroplásticos en respuesta a la luz (Jensen et al., 1986; Danon y Mayfield, 1991); (ii) la modulación de procesos de desarrollo (Jacobsen et al., 1999; Li et al., 2001); (iii) la señalización hormonal (Lu y Fedoroff., 2000; Hugouvieux et al., 2001) y (iv) el silenciamiento génico (Hutvagner, 2005). Una de las familias más estudiadas es la de las proteínas de unión a RNA ricas en Gly (Glycine rich proteins, GRPs) y numerosos estudios sugieren que dichas proteínas estarían implicadas en respuestas a estrés mediante mecanismos de regulación post-transcripcional. 
En los virus de plantas con un genoma de ssRNA de polaridad positiva, como es el caso del virus objeto del presente estudio, se han descrito interacciones entre su genoma y las replicasas, las proteínas de cubierta y las proteínas de movimiento:

(i) la RdRp requiere la presencia en el RNA diana de estructuras especificas tipo tRNA, colas poli(A), pseudonudos, tallo-bucle y/o determinadas secuencias de nucleótidos que desempeñan al menos dos funciones: reclutar a la RdRp y permitir el inicio de la replicación del genoma (Nagy, 1999).

(ii) los procesos de ensamblaje de las partículas víricas están determinados tanto por interacciones proteína-proteína, como por interacciones RNA-proteína dependientes o independientes de secuencia. Muchos de estos virus suelen poseer una CP con un extremo Nterminal flexible y de carácter básico que está implicado en la interacción con los grupos fosfato del RNA (Oostergetel et al., 1983; Silva y Rossmann, 1987; Sacher y Ahquist, 1989). La encapsidación del RNA debe ser selectiva, lo que se consigue mediante la compartimentalización celular o mediante interacciones con secuencias y estructuras concretas. Las interacciones RNA-proteína específicas de secuencia son probablemente las más críticas en el inicio del ensamblaje. En general, se ha demostrado que en las interacciones CP-RNA viral hay una especificidad al menos a nivel de género (Pallás et al., 1999). Además del papel estructural de las CP se les han caracterizado y asignado otras funciones relevantes durante el ciclo infeccioso. Por ejemplo, en llarvirus y el Virus del mosaico de la alfalfa (Alfalfa mosaic virus, AMV), el inicio de la replicación requiere la unión de la CP al extremo 3' del RNA en un fenómeno conocido como "activación genómica". Tanto la CP como el extremo 3' del genoma de los llarvirus pueden considerarse macromoléculas multifuncionales cuyas funciones biológicas son mutuamente dependientes (Aparicio et al., 2003; Bol, 2005).

(iii) las proteínas de movimiento virales, en la mayoría de los casos, deben ser capaces de interaccionar con el material genético del virus y conducirlo desde el citoplasma de la célula infectada al de una célula vecina y así sucesivamente hasta llegar al sistema vascular. Esta propiedad de unión a ácidos nucleicos de las MPs la comparten géneros de virus de plantas tan diversos como Tobamovirus, Caulimovirus, Dianthovirus, Alfamovirus, Tospovirus, Umbravirus, Bromovirus, Cucumovirus, Fabavirus, Sobemovirus, Carmovirus, Necrovirus, Tombusvirus, Geminivirus, Hordeivirus, Potexvirus, Pomovirus y Luteovirus. En la mayor parte de los casos descritos, la interacción MP-RNA no es dependiente de secuencia e incluso se ha demostrado que se puede dar el intercambio entre MPs de diferentes virus sin provocar el bloqueo del movimiento célula a célula de los mismos (Solovyev et al., 1996; Solovyev et al., 1997; Aparicio et al., 1999; Sanchez-Navarro et al., 2006). Así, las MP intercambiadas, dada su inespecificidad de secuencia, son capaces de unir y transportar diferentes genomas virales en mayor o menor medida, por ello, los virus deberán adoptar diferentes estrategias, como la compartimentalización, para incrementar la especificidad. 
Aunque la mayoría de MPs virales compartan la capacidad de unión a RNA/DNA, los detalles de dicha unión, así como los dominios involucrados en la misma, varían entre grupos virales, aunque la mayoría poseen un dominio rico en aminoácidos básicos. La observación de que sólo un reducido número de residuos de aminoácido se conserven entre las MPs, junto con la capacidad de unir ácidos nucleicos de simple cadena sugiere la idea de que la actividad de las MPs se realice también en función de su estructura secundaria y terciaria. En este sentido, se ha encontrado que la MP del TMV presenta un plegamiento predominante en $\alpha$-hélice adoptando una estructura terciaria altamente estable necesaria para el correcto funcionamiento de la proteína (Brill et al., 2000). Para la MP del PNRSV se ha caracterizado el dominio de unión a RNA, RBD (RNA Binding domain), presente en el extremo $\mathrm{N}$ terminal de la proteína (Herranz y Pallás, 2004). Además el análisis mutacional de esta región ha revelado que los aminoácidos básicos presentes en el mismo están directamente implicados en la unión a RNA y en el movimiento del virus (Herranz et al., 2005). Asimismo, la p7 del CarMV presenta en su región central una estructura en $\alpha$-hélice esencial en la interacción con el RNA (Villar et al., 2005). Mediante la utilización de péptidos sintéticos correspondientes al dominio de unión a RNA de p7 (Marcos et al., 1999), se ha puesto de manifiesto que la interacción entre el péptido y el RNA es de tipo adaptativo (Vilar et al., 2001) y según la hipótesis propuesta ambos, péptido y RNA, deben modificar su conformación para que se produzca una interacción eficiente. En la mayoría de casos descritos, se ha demostrado que la capacidad de unión a RNA de estas MPs es preferentemente a los ácidos nucleicos de simple cadena frente a los de doble hebra (Vaquero et al., 1997). Además, esta unión es inespecífica de secuencia y en muchos casos cooperativa.

En todos los casos, los complejos MP-ácido nucleico representan estructuras intermediarias del proceso de movimiento viral, también conocidos como complejos $M$ (refiriéndose a movimiento). De este modo, el material genético de estos complejos se halla protegido frente a actividades enzimáticas celulares y empaquetado para ser transportado al plasmodesmo (Citovsky et al., 1992). Por otro lado, en el transporte célula a célula del genoma viral, además del complejo $\mathrm{M}$, están involucrados numerosos factores de la célula huésped.

\section{EL MOVIMIENTO DE LOS VIRUS DE PLANTAS}

La propagación de una infección viral en una planta huésped presenta dos etapas distintas y secuenciales. La primera es el movimiento local o célula a célula y comprende el desplazamiento del virus por el citoplasma de la célula infectada hacia la periferia, llamado movimiento intracelular y el transporte del virus desde la célula inicialmente infectada a sus células vecinas, llamado movimiento intercelular. Para llevar a cabo este último proceso, los virus atraviesan la pared celular aprovechando los plasmodesmos, que como se ha mencionado anteriormente son complejos puentes citoplasmáticos que interconectan las células de las plantas. El transporte viral y por tanto, el paso a través de los plasmodesmos es dirigido principalmente por las proteínas de movimiento (MP) codificadas en el genoma viral y 
que funcionan: (i) formando complejos ribonucleoproteicos con el RNA viral, y facilitando el paso a través de los plasmodesmos aumentando el limite de exclusión molecular (Size exclusión limit, SEL) de los mismos; (ii) generando túbulos proteicos, estructuras que desorganizan totalmente la arquitectura original de los plasmodemos preexistentes y por los que son conducidas las partículas virales. Las MPs son codificadas por todos los virus, pero el número, la estructura y la interacción con factores de la célula huésped, así como el modo de acción, varía dependiendo del tipo viral. Por último, moviéndose célula a célula, el virus llega a situarse frente a las células especializadas del sistema vascular de la planta. En esta posición, una cadena de eventos sucesivos da lugar al movimiento sistémico que incluye la entrada al tejido vascular, la distribución a partes distales de la planta, normalmente desde el floema aunque en algunos casos también puede realizarse desde el xilema, y por ultimo, la salida del tejido vascular o descarga del virus en tejidos no infectados.

Respecto a otros determinantes virales implicados en el movimiento local y sistémico se incluyen la proteína de la cápsida (CP), las replicasas, e incluso, en el caso de Potivirus, una proteinasa denominada HCPro (Helper component proteinase) y la proteína Vpg. Además, dado que muchas proteínas virales implicadas en el movimiento están a su vez actuando como supresores de los mecanismos de defensa de la planta, se hace difícil discernir entre un efecto indirecto de las mismas sobre el movimiento o una acción directa sobre la función de movimiento per se. En este punto, es importante destacar que un bloqueo en el movimiento sistémico es frecuentemente la causa de la resistencia de la planta a enfermedades virales.

\subsection{Las proteínas de movimiento.}

10.1.1 Estructura de las MPs virales. En base a la secuencia de aminoácidos, las MPs de los virus de plantas, se pueden clasificar en: (i) las pequeñas MPs de Carmovirus y Geminivirus, menores de $10 \mathrm{kDa}$; (ii) las grandes de Tymovirus, $69-85 \mathrm{kDa}$; (iii) el grupo del bloque de tres genes (Triple gene block, TGB) de Potexvirus, Carlavirus, Allexvirus, Foveavirus, Hordevirus, Benyvirus, Pomovirus y Pecluvirus y (iv) la Superfamilia de las $30 \mathrm{k}$, que constituye el grupo mayoritario e incluye hasta 18 géneros diferentes de virus de plantas entre ellos Ilarvirus, Alfamovirus o Bromovirus.

(a) Superfamilia de las $\mathbf{3 0 k}$. Las MPs de la Superfamilia de las $30 \mathrm{k}$ comparten baja similitud en su secuencia, con un solo motivo conservado LXDX ${ }_{50-70} G$. Sin embargo, presentan una conformación tridimensional común, con la estructura central conservada, formada por cuatro $\alpha$-hélices ( $\alpha-A-D)$ y siete $\beta$-hojas ( $\beta-1-7)$, y los dominios $N$ terminal $(N t)$ y $C$ terminal $(C t)$ variables (Melcher, 1990; Melcher, 2000). La proteína de movimiento del TMV contiene 268 aminoácidos y es la proteína más estudiada de esta gran familia de MPs virales. En la figura 13 se presenta un esquema detallado de las regiones de la proteína implicadas en las diferentes funciones (revisado en Waigmann et al., 2007): 
(i) La MP del TMV une ácidos nucleicos de simple cadena de forma cooperativa e inespecífica de secuencia (Citovsky et al., 1992), formando partículas ribonucleoproteicas (Viral ribo nucleo proteins, vRNP) que atraviesan los plasmodesmos celulares (Waigmann et al., 1994b). Esta función recae sobre dos dominios de unión a RNA adyacentes pero independientes (dominio A y B).

(ii) Por otro lado, esta proteína altera el SEL sin producir cambios estructurales en el plasmodesmo y media en el transporte célula a célula del complejo RNA-MP. El mecanismo por el cual la MP es capaz interaccionar con los PDs y modificar el SEL todavía es desconocido pero esta función parece recaer sobre el dominio E (posiciones 126 a 224).

(iii) La MP del TMV, además, presenta dos dominios hidrofóbicos considerados posibles fragmentos integrales de membrana. En este sentido, se ha encontrado asociada con la fracción microsomal (Brill et al., 2000) como proteína integral de membrana (Reichel et al., 1998). En ensayos in vitro se ha observado que el extremo Ct es altamente sensible al tratamiento con tripsina, posiblemente por mantenerse expuesto al citosol. Se ha propuesto, por tanto, que la MP del TMV se inserta en la membrana del RE a través de estos dos fragmentos hidrofóbicos, adquiriendo forma de $\mathrm{U}$ y dejando tanto el extremo $\mathrm{Nt}$ como el $\mathrm{Ct}$

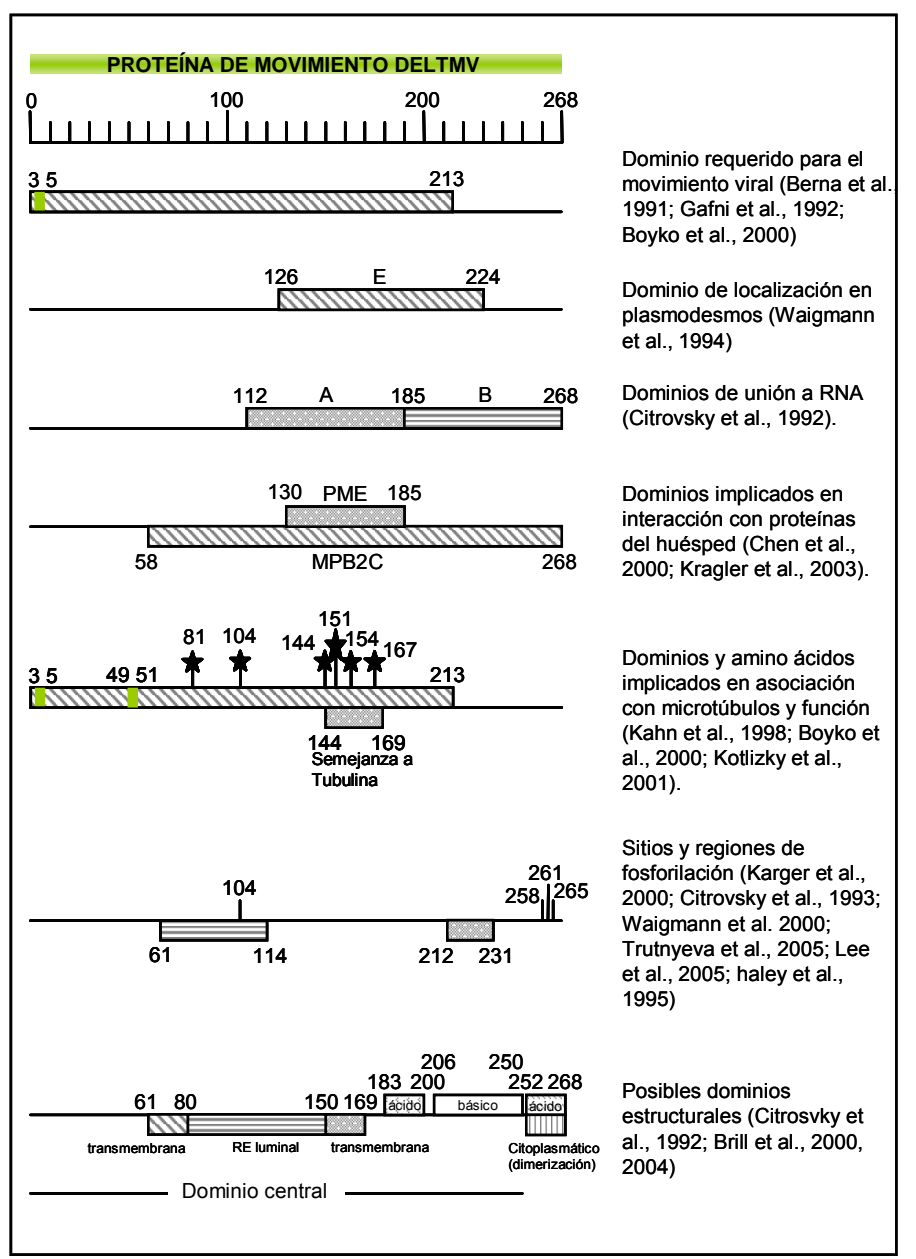

Figura 13. Representación esquemática de las regiones de la proteína de movimiento del TMV implicadas en el desarrollo de las funciones descritas para la misma. Las zonas del genoma sombreadas se corresponden con la función descrita al margen y están acotadas por los aminoácidos marcados en los extremos. Las posiciones concretas implicadas en cada función se encuentran detalladas con la numeración del aminoácido correspondiente. Figura adaptada de Waigmann et al., 2007. Plant Cell Monogr. 7, 29-62. 
expuestos al citosol (Brill et al., 2000). Sin embargo, recientemente se ha cuestionado esta última característica y se especula con que ésta sea más una proteína asociada a membrana que una integral (Fujiki et al., 2006).

(iv) Por último, esta proteína contiene también un dominio implicado en la interacción con los microtúbulos similar al lazo $\mathrm{M}$ de la $\alpha, \beta$, y $\gamma$-tubulina. Este dominio de la tubulina es esencial para la formación y la estabilidad de los microtúbulos. Puesto que esta MP es capaz de formar homodímeros, se ha propuesto que una unidad proteica interaccionaría con el RE mientras que la otra lo haría con el citoesqueleto.

(b) El bloque de dos genes de los Carmovirus (Double gene block, DGB). Los carmovirus presentan en la region central de su genoma dos pequeñas ORFs adyacentes que se conocen como el bloque de dos genes (Double gene block, DGB) (ver apartado 5). Las proteínas correspondientes se han denominado de forma general como DGBp1 y DGBp2, según su posición en el genoma viral, aunque en cada especie reciben un nombre específico de acuerdo con su masa molecular. La implicación de estas proteínas en el movimiento local ha sido descrita únicamente en el caso del TCV que ha sido considerado la especie tipo del género. Sin embargo, las DGBps correspondientes al Virus del moteado del clavel (Carnation mottle virus, CarMV) han sido mejor caracterizadas estructuralmente. El CarMV codifica dos pequeñas proteínas, p7 (DGBp1) y p9 (DGBp2) que, a pesar de no compartir motivos de secuencia con la Superfamilia de la $30 \mathrm{k}$, poseen dominios funcionales similares.

La utilización de programas informáticos de predicción de estructura secundaria junto con una serie de datos experimentales de espectroscopia por resonancia magnética nuclear (RMN), han permitido aproximarse a la estructura secundaría de estas proteínas. La p7 presenta tres dominios: el $\mathrm{Nt}$, variable y desestructurado, el $\mathrm{Ct}$, plegado en una $\beta$-hoja estable y el dominio central, con estructura en $\alpha$-hélice que, como se ha avanzado en el apartado anterior, es responsable de la unión a RNA tanto a nivel de estructura primaria como secundaria (Marcos et al., 1999; Vilar et al., 2001; Vilar et al., 2005). Por otro lado, la existencia de fragmentos transmembrana no es una característica aislada de la Superfamilia de las $30 \mathrm{k}$ sino que es compartida por otras MPs de virus como la p9 del CarMV. Así pues, este factor viral es estructuralmente una proteína integral de membrana con dos dominios hidrofóbicos, capaz de insertarse in vitro en la membrana del retículo endoplasmico en forma de $U$ exponiendo los extremos $\mathrm{Nt}$ y $\mathrm{Ct}$ hacia el lado citoplasmático de la misma en un proceso cotraduccional asistido por la maquinaria del translocón (Vilar et al., 2002, Sauri et al., 2005). Además de estos dominios hidrofóbicos, la p9 presenta un extremo Ct con un potencial plegamiento en $\beta$-hoja plegada cuya función se desconoce.

(c)El bloque de tres genes de Potexvirus y Hordeivirus (Triple gene block, TGB). Por otro lado, otros grupos de virus presentan hasta tres ORFs esenciales en el movimiento célula a célula de manera contigua o muy poco solapada en su genoma constituyendo el característico bloque de 3 genes (Triple gene block, TGB) (Morozov y Solovyev, 2003). El factor 
proteico correspondiente a cada gen se denomina TGBp1, TGBp2 y TGBp3, en sentido 5'-3'. Los virus que presentan este sistema de proteínas de movimiento pueden dividirse en dos clases: la clase 1 incluye los géneros Hordeivirus, Pecluvirus, Pomovirus y Benyvirus que son virus que presentan una morfología de varilla; en la clase 2 se encuentran virus filamentosos pertenecientes a los géneros Potexvirus, Carlavirus, Foveavirus y Allexivirus que aparte de las TGBps requieren la CP para su movimiento célula a célula. Las TGBp1 de la clase 2 presentan una masa molecular de unos 24-26 kDa y contienen un dominio NTPasa/helicasa que ocupa prácticamente la totalidad de la molécula. Las TGBp1 de la clase 1 presentan un tamaño superior a las anteriores (39-63 kDa) y se caracterizan igualmente por poseer un dominio NTPasa/helicasa pero también por presentar una extensión del extremo Nt con varias regiones ricas en Arg y Lys implicadas en la unión de RNA, propiedad funcional que comparte con las TGBp1 de la clase 2 (Wung et al., 1999, Kalinina et al., 2002, Morozov et al., 2003). Por otro lado, las TGBp2 y TGBp3 contienen dominios hidrofóbicos capaces de insertarse en la membrana. La TGBp2 presenta dos secuencias hidrofóbicas internas y separadas por una región central muy conservada, mientras que la TGBp3 presenta una estructura más variable Las TGBp3 de la clase 1 poseen dos posibles fragmentos transmembrana mientras que las correspondientes a los virus de la clase 2 presentan un único dominio hidrofóbico. Además, los motivos de secuencia conservados difieren en cada grupo (Morozov et al., 2003). Existen evidencias experimentales de que ambas proteínas son capaces de insertarse en la membrana del RE; TGBp2 lo hace en forma de $U$ y exponiendo los extremos al lado citoplasmático, mientras que las TGBp3 que tienen un solo fragmento transmembrana dejan el extremo $\mathrm{Nt}$ en el lumen del RE y las que tienen dos exponen tanto el $\mathrm{Nt}$ como el $\mathrm{Ct}$ al lúmen (Morozov et al., 2003).

10.1.2 Localización subcelular de las MPs virales. Los patrones específicos de localización subcelular de las proteínas virales, pueden darnos información sobre su función. Por este motivo, son cada vez más los estudios realizados con esta finalidad. Las MPs virales se han localizado en orgánulos del interior de la célula tan diversos como los plasmodesmos, el citoesqueleto, la red del retículo endoplasmático e incluso, el núcleo celular. Numerosas aproximaciones han dado lugar a la información anterior, incluyendo principalmente técnicas de fraccionamiento subcelular y de microscopía; la detección mediante el uso del marcaje inmunoquímico o la fusión a proteínas fluorescentes.

(a) Interacción con plasmodesmos. La MP del TMV se ha localizado en estructuras punteadas en la pared celular. Esta observación ha sido corroborada por diferentes aproximaciones en: (i) plantas transgénicas expresando la MP del TMV (Atkins et al., 1991; Ding et al., 1992); (ii) plantas infectadas por el TMV (Tomenius et al., 1987); (iii) plantas que expresan la MP fusionada a la proteína de fluorescencia verde en su extremo Ct durante una infección viral (Boyko et al., 2000c), transitoriamente (Crawford y Zambryski, 2001) o constitutivamente desde un transgen (Roberts et al., 2001). Estas estructuras punteadas que la 
MP del TMV forma en la pared celular se corresponden, como se ha descrito antes, con los plasmodesmos celulares (Oparka et al., 1997). Además, MPs de la superfamilia 30K de otros virus, como el AMV, el Virus del mosaico del pepino (Cucumber mosaic virus, CMV) o el Virus del mosaico del bromo (Brome mosaic virus, BMV) se han observado también formando el mismo tipo de punteaduras en la pared celular.

La capacidad de modificar el tamaño de exclusión del plasmodesmo de las MP virales fue descrita por primera vez en plantas transgénicas de tabaco que expresaban la MP del TMV (Wolf et al., 1989). Del mismo modo, plantas de tabaco expresando las MPs del CMV, el AMV, el Virus del enrollamiento de la hoja de la patata (Potato leaf roll virus, PLRV) o la TGBp1 del Virus del mosaico del trébol blanco (White clover mosaic virus, WCIMV) tienen aumentada la permeabilidad de sus plasmodesmos. De esta forma, es probable que las MPs virales contengan señales de transporte específicas que les confieran selectividad y sean esenciales para que se de un transporte activo a través del plasmodesmo (Waigmann et al., 1994; Waigmann y Zambryski, 1994).

Por otro lado, las MPs pertenecientes a virus no relacionados filogenéticamente muestran un patrón similar de punteaduras en la pared celular. Por ejemplo, la MP del PLRV, una proteína de $17 \mathrm{kDa}$ que no pertenece a la superfamilia de las $30 \mathrm{~K}$, también marca los plasmodesmos celulares cuando se expresa, sola o fusionada a GFP, en plantas trasgénicas de tabaco (Sokolova et al., 1997). La p7 de CarMV se asociada con la pared celular especialmente en estadios tardíos de la infección en C. quinoa (Garcia-Castillo et al., 2003). Respecto a las proteínas de movimiento del bloque del triple gen (TGB), la proteína TGBp1 copurifica con la fracción de pared celular y se localiza en plasmodesmos, aunque, interesantemente, las proteínas TGBp2 y TGBp3 son requeridas para que se dé esta distribución (Erhardt et al., 1999).

(b) Interacción con componentes del citoesqueleto. La interacción de una MP viral con componentes del citoesqueleto fue descrita por primera vez con la MP tipo Hsp70 del Virus del amarillamiento de la remolacha (Beet yellow virus, BYV) (Karasev et al., 1992). Dicha interacción fue posteriormente observada para la MP del TMV (Heinlein et al., 1995a; Heinlein et al., 1995b; Mclean et al., 1995). Además, la MP del TMV es capaz de interaccionar tanto con moléculas de tubulina como de actina, esta unión es muy estable y podría actuar estabilizando la red de microtúbulos, como ocurre con las proteínas asociadas a microtúbulos (Microtubule Associated Proteins, MAPs) de células animales.

A pesar de no estar claro el significado de la interacción entre las proteínas virales y los microtúbulos y dado que estos están implicados, entre otros, en procesos de transporte intracelular de ácidos nucleicos, una hipótesis probable es la implicación del citoesqueleto en el transporte de genomas virales mediado por las MP. Así, se ha demostrado que los microtúbulos están implicados en la distribución del RNA del TMV (Bloom y Beach, 1999; Mas y Beachy, 1999; Mas y Beachy, 2000). De este modo, el RNA del TMV colocaliza con los 
microtúbulos en protoplastos infectados con TMV de una manera dependiente de la MP. EI tratamiento con orizalina, una droga que impide el ensamblaje de los microtúbulos, modifica la distribución del RNA viral que pasa a ocupar el citoplasma y la superficie celular (Mas y Beachy, 1999). Sin embargo, ni la acumulación de la MP de TMV en microtúbulos, ni estas estructuras per se, son imprescindibles para que exista transporte del virus (Gillespie et al., 2002). Aunque actualmente es un tema de debate, existen evidencias experimentales que indican que los microtúbulos no parecen tener un papel directo sobre el movimiento del TMV sino que más bien están implicados en la degradación de la MP (Seemanpillai et al., 2006). Sin embargo, estudios recientes realizados con el BYV, un Closterovirus no relacionado filogenéticamente con el TMV, han demostrado la implicación de los microfilamentos de actina durante la localización de su MP, del tipo Hsp70, en los plasmodesmos celulares (Prokhnevsky et al., 2005).

(c) Interacción con el sistema de endógeno de membranas. Experimentos de fraccionamiento subcelular de tejidos infectados con TMV pusieron de manifiesto que la MP del TMV se asocia tanto a la fracción correspondiente a la pared celular como a la soluble e, interesantemente, a la de endomembranas (Deom et al., 1990). Por otro lado, el patrón de distribución subcelular de la fusión MP(TMV)-GFP mostró pequeños cuerpos corticales fluorescentes asociados con la red del retículo endoplasmático que precedían su posterior localización en los microtúbulos (Reichel y Beachy, 1998).

La asociación de las proteínas de movimiento virales con la red del retículo endoplasmático, no es exclusiva de los miembros de la Superfamilia de las $30 \mathrm{~K}$. Dos de las proteínas que forman parte del TGB, TGBp2 y TGBp3, están asociadas con estructuras derivadas del RE (Morozov et al., 2003). TGBp2 forma pequeñas vesículas móviles asociadas con la red cortical del RE. Esta asociación es requerida, aunque no suficiente, para el movimiento del virus. Por otro lado, TGBp3 se acumula en la superficie celular en estructuras conectadas con el RE y próximas a los plasmodesmos (Morozov et al., 2003). Puesto que TGBp1 forma complejos con el RNA viral, el papel de TGBp2 y TGBp3 podría ser el del transporte de dichos complejos al plasmodesmo, con el subsiguiente transporte célula a célula del virus (Morozov et al., 2003). Finalmente, la p9 del CarMV se asocia a membranas que derivan del RE (Vilar et al., 2002).

(d) Localización nuclear. Los Geminivirus se replican en el núcleo y por tanto su genoma debe ser transportado a través de la membrana nuclear al citoplasma y viceversa. Esta función es realizada por proteínas de movimiento virales o, en algunos géneros, por la CP. Los Geminivirus de genoma bipartito presentan dos proteínas implicadas en el movimiento, BR1 y BL1. La proteína BL1 es capaz de aumentar el tamaño de exclusión molecular de los PD y de mediar el transporte célula a célula del DNA viral (Rojas et al., 1998). La proteína BR1 se localiza en el núcleo, une DNA (Noueiry et al., 1994) y puede actuar como proteína lanzadera nuclear (nuclear shuttle protein, NSP). La interacción entre ambas proteínas regula el 
transporte intracelular del DNA viral (Sanderfoot et al., 1996). En los Geminivirus de genoma monopartito, la CP es necesaria para la infección y poseen una única MP. Exceptuando los Curtovirus, la CP interacciona con el DNA y se localiza en el núcleo (Kunik et al., 1998; Liu et al., 1997). Se ha demostrado que en este caso, la CP facilita el transporte del DNA viral hacia el núcleo, sugiriendo que realiza funciones características de BR1 en los Geminivirus de genoma bipartito (Liu et al., 1999). Otro ejemplo de localización nuclear, en concreto nucleolar, es la ORF3 del Virus de la roseta del cacahuete (Groundnut rosette virus, GRV), un Umbravirus que, a pesar de presentar un genoma de RNA, es capaz de interaccionar con el material genético, localizarse en el núcleo o en el nucleolo celular y reorganizar los Cuerpos de Cajal, paso imprescindible para que se de la infección sistémica (Kim et al., 2007). Esta proteína presenta un dominio rico en Arg y una región rica en Leu responsables, respectivamente, de la entrada y salida del núcleo (Ryabor et al., 2004a). Recientemente se ha demostrado que la proteína interacciona con la fibrilarina, una de las proteínas nucleolares más abundantes y que esta interacción es esencial para la infección sistémica del virus (Kim et al., 2007). La capacidad de esta proteína para ser importada al núcleo depende de dos señales de localización nuclear (nuclear localization signal, NLS) presentes en su secuencia y que son prescindibles para el movimiento célula a célula. La localización nuclear también se ha observado para la p8, una de las dos MPs del TCV (Cohen et al., 2000b). Esta localización es única entre los Carmovirus y la relación entre su localización nuclear y el movimiento célula a célula es, hasta la fecha, una incógnita, dado que se trata de un virus de RNA.

(e) Otras localizaciones subcelulares. La proteína p7 de CarMV, homóloga a p8 del TCV, presenta una distribución principalmente citosólica en plantas de C. quinoa infectadas con CarMV y a tiempos más largos es detectada en la pared celular, sin embargo, esta proteína no se ha hallado nunca asociada al núcleo (Garcia-Castillo et al., 2003). Un último ejemplo de localización subcelular de proteínas de movimiento virales es la MP del BMV que se halla en cuerpos de inclusión citoplasmáticos (Fujita et al., 1998) o la TGBp1 del Virus $X$ de la patata (Potato virus $X, \mathrm{PVX}$ ), también localizada en el citoplasma, pero no en cuerpos de inclusión (Yang et al., 2000).

Del análisis de los patrones de distribución de las MPs puede deducirse información relacionada con su función. Muchas MPs virales se unen a sus genomas, dando lugar a complejos ribonucleoproteicos que pasan a través de los plasmodesmos durante el movimiento célula a célula. Por ello, la localización de estas MPs en plasmodesmos puede tener un significado biológico relacionado con su función. Por tanto, de los resultados obtenidos en los últimos años cabe deducir que la periferia celular es diana de MPs de diferentes grupos virales, como Tobamovirus, Bromovirus, Geminivirus, Trichovirus, Umbravirus, Luteovirus y virus que presentan el TGB. Por otro lado, es frecuente observar una asociación entre las MPs y el retículo endoplasmático como ocurre en Tobamovirus, Bromovirus, Geminivirus, Tombusvirus y MPs del TGB. Sin embargo, la asociación con el núcleo celular sólo se ha descrito para las 
MPs de Geminivirus y para un miembro de los Carmovirus, el TCV. Por último, la asociación con microtúbulos ha sido ampliamente descrita para el TMV aunque, como se ha mencionado, ésta no es un requisito para que se dé el movimiento del virus.

10.1.3 Interacciones de las MPs con factores proteicos del huésped. Dada la limitada capacidad codificante de los virus de plantas, éstos deben reclutar proteínas del huésped para completar su ciclo de infección. Para llevar a cabo su movimiento intra e intercelular los virus interaccionan con proteínas celulares de la membrana, de andamiaje o implicadas en rutas de secreción. Así, la MP del TMV es capaz de interaccionar con una pectina metilesterasa (PME) de la pared celular (Min-Huei y Citrosvky, 2003), participando dicha unión en el movimiento viral dado que la acción de este enzima modula, indirectamente, la permeabilidad del plasmodesmo. La MP del TMV también es capaz de interaccionar con una proteína de plantas de tabaco asociada a microtúbulos (MPB2C) (Curin et al., 2007) que se encuentra implicada en la acumulación de la proteína viral en estos orgánulos. Más aún, esta MP es capaz de interaccionar con quinasas celulares (Yoshioka et al., 2004; Lee et al., 2005), siendo el estado de fosforilación/deforilación un posible mecanismo que determina o modula las diferentes actividades en las que se encuentran involucradas las MPs virales (Karpova et al., 1999). Por último, la interacción con la calreticulina de la MP del TMV es necesaria para su localización en el plasmodesmo celular (Chen et al., 2005).

Existen más ejemplos, diferentes a los descritos anteriormente, de interacciones entre factores celulares y proteínas de movimiento de otros virus (Morozov et al., 2003; Lucas y Lee, 2004; Taliansky, 2006; Lucas, 2006). La información obtenida de todos ellos, nos puede ayudar a conocer los mecanismos de movimiento de los virus de plantas.

En síntesis, la atribución de mediar en el tráfico entre células de las MPs virales vendría asignada por la capacidad de: (i) interaccionar y transportar los ácidos nucleicos en el interior de la célula; (ii) beneficiarse de factores del huésped en el desarrollo de sus funciones y (iii) interaccionar con el plasmodesmo y modificar su tamaño de exclusión, para el transporte a la célula vecina.

\subsection{Modelos de sistemas de transporte viral célula a célula.}

10.2.1 Movimiento viral basado en la formación de complejos ribonucleoproteicos: el Virus del mosaico del tabaco (TMV). Se ha demostrado experimentalmente que la MP del TMV sigue un patrón temporal de distribución en el interior de la célula. Durante las primeras etapas de la infección viral esta proteína se acumula en el RE así como en los plasmodesmos celulares pero, más tarde, se detecta en cuerpos de inclusión asociados con la membrana del RE y en los microtúbulos. Finalmente, la proteína desaparece de todas las localizaciones excepto de los plasmodesmos (Heinlein et al., 1998b). El uso combinado de diferentes drogas que actúan bloqueando la funcionalidad de determinadas rutas celulares de transporte ha permitido establecer la implicación de los microfilamentos de actina, con los que la MP del TMV 
es capaz de interaccionar, y del RE en el transporte de estas MPs a los plasmodesmos (Wright et al., 2007).

Los cuerpos de inclusión derivados del RE probablemente representan los sitios de replicación viral y síntesis proteica. En su interior se acumula la replicasa (Heinlein et al., 1998a), el RNA viral (Mas y Beachy, 1999) y la CP (Asurmendi et al., 2004). Estos complejos replicativos virales (Virus-replication complexes, VRCs) asociados a membrana son comunes en otros virus y pueden representar un mecanismo de compartimentalización para regular eficientemente la replicación, la traducción, el movimiento viral y la contradefensa a la respuesta de defensa de la planta huésped. En este contexto de replicación y movimiento, el TMV podría moverse por el interior de la célula en forma de cuerpos de inclusión o vesículas derivadas del RE que incluirían a la MP y a los VRCs (Kawakami et al., 2004). Además, existen estudios que muestran la implicación de los microfilamentos de actina en el movimiento célula a célula del TMV, quizá por dirigir estos VRCs a través del plasmodesmo (Liu et al., 2005) (Figura 14). Sin embargo, varias evidencias experimentales apuntan a que la formación de estos cuerpos de inclusión no es esencial ni para la replicación ni para el movimiento del virus. Por ejemplo, aunque éstos no se forman en ausencia de la MP (Mas y Beachy, 1999), construcciones del TMV deficientes en su síntesis son capaces de replicarse. Además, en esta situación, el RNA viral sigue localizándose en el RE, sugiriendo que dicha asociación es una propiedad intrínseca de éste y/o de la replicasa (Mas y Beachy, 1999). Por otro lado, estudios recientes implican a la replicasa viral en el movimiento célula a célula. Esta situación podría deberse a que las RdRp residentes del RE, desde esta localización, transferirían el RNA viral a las MPs facilitando su transporte hacia los plasmodesmos. No se puede descartar, no obstante, que el efecto de la RdRp sobre el movimiento célula a célula pueda ser un reflejo de su acción conocida sobre el VIGS (Ding et al., 2004).

En principio, la asociación de la MP a los microtúbulos podría estar relacionada con el movimiento del RNA viral (Boyko et al., 2000a; Boyko et al., 2000b; Kotlizky et al., 2001; Boyko et al., 2002). Dado que esta MP es capaz de dimerizar, se ha especulado que una subunidad interaccionaría con la tubulina de los microtúbulos mientras que la otra lo haría con el RE. De esta forma, el homodímero de la MP actuaría como un puente entre los microtúbulos y el RE, facilitando el transporte a través del citoesqueleto del RNA viral asociado a las membranas (Ferralli et al., 2006). No obstante, según se desprende del tratamiento con agentes desestabilizantes de estas estructuras del citoesqueleto, la acumulación de la MP del TMV en microtúbulos no es necesaria para el avance de la infección (Gillespie et al., 2002). Por tanto, la implicación de los microtúbulos en el movimiento del TMV es un tema de debate en la actualidad y no se puede descartar la implicación de la tubulina en la función de la MP del TMV (Seemanpillai et al., 2006). La unión entre la MP y los microtúbulos se relacionó con un reciclaje de la proteína mediada por el proteosoma 26 debido a que únicamente aparece en etapas tardías de la infección. Sin embargo, la MP asociada no se encontraba modificada mediante ubiquitinación por lo que no debería entrar en esta ruta degradativa (Ashby et al., 
2006). Además, se ha postulado que este complejo podría, al afectar la movilidad mediada por los motores del citoesqueleto, bloquear el transporte de determinadas moléculas, como pueden ser las señales responsables de generar un silenciamiento génico generalizado en la planta, a células no infectadas (Ashby et al., 2006). Este efecto, junto con la regulación de SEL del plasmodesmo observado también en etapas tardías de la infección (Oparka et al., 1997), podría bloquear el movimiento del virus a células infectadas y favorecer un transporte direccional del virus hacia el tejido sano.

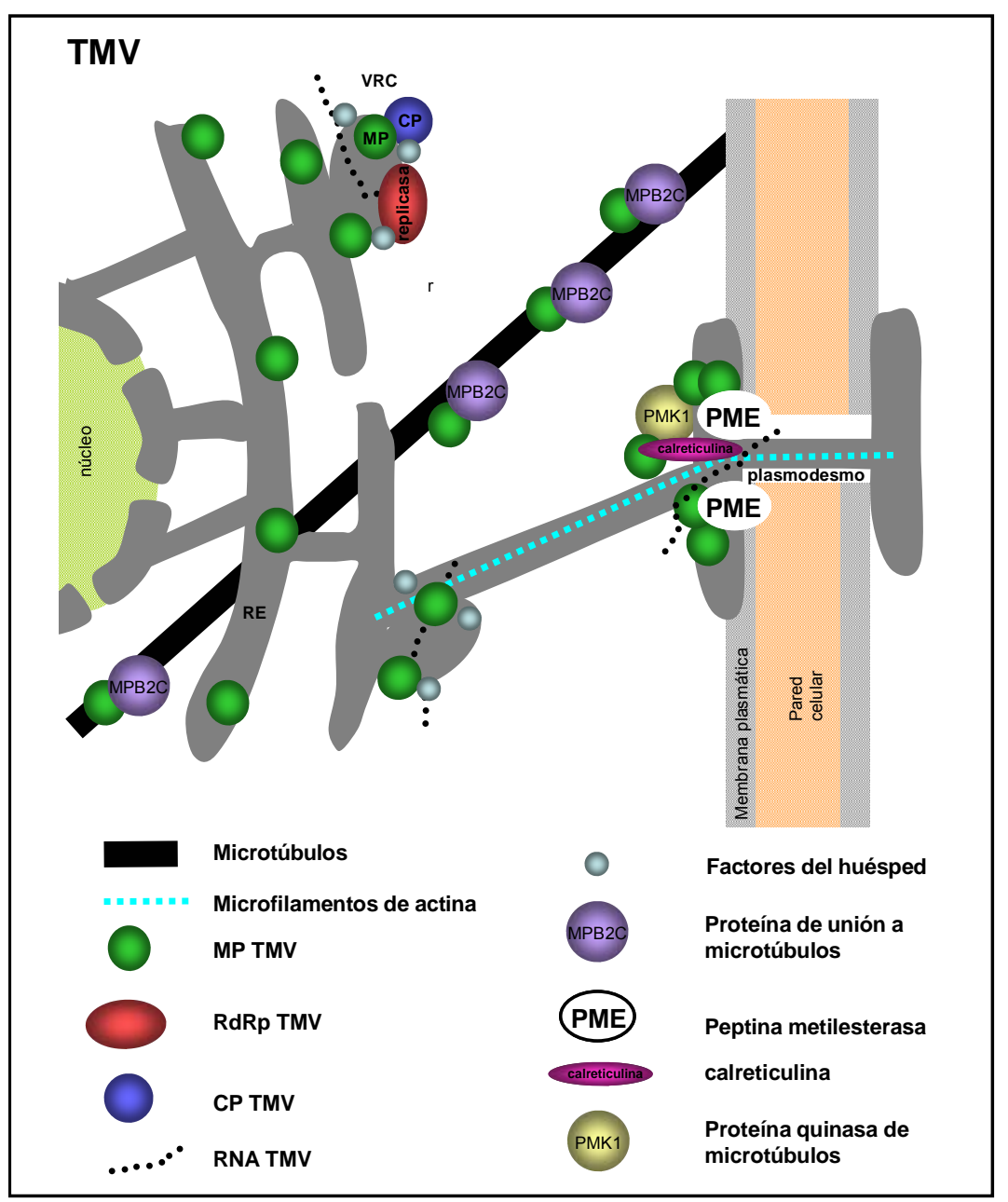

Figura 14. Posibles rutas intra-celulares seguidas por la MP del TMV en su camino a la periferia celular, según los datos actuales de interacción de la misma con factores de la célula huésped (ver revisión en Waigmann et al., 2007).

10.2.2 Movimiento viral quiado por túbulos. El plasmodesmo celular permite solamente la difusión entre células vecinas de pequeñas moléculas. Sin embargo, los virus, a través de sus proteínas de movimiento son capaces de modificarlo bioquímica y estructuralmente para permitir el paso de los complejos ribonucleoproteícos virales, vRNP, o de viriones completos. En este último caso, la proteína de movimiento es capaz de formar unas estructuras tubulares que desestructuran el desmotúbulo del plasmodesmo y permiten el paso de los viriones por su interior. De esta forma, algunos virus de plantas mueven entre células su material genético 
encapsidado a través de unas estructuras conocidas como túbulos. Ésta es una capacidad intrínseca de algunas proteínas de la Superfamilia de las 30k.

El Virus del mosaico del chícharo (Cowpea mosaic virus, CPMV) fue el primero en el que se describió la capacidad de formar túbulos (Scheer y Groenewegen, 1971). Aunque más tarde se demostró que tanto la MP (p48) como la CP estaban implicadas en el movimiento de este virus, únicamente la primera se encontró formando parte estructural de los túbulos. Además, la MP resultó ser necesaria y suficiente para la generación de estas estructuras dado que mutantes deficientes para la $\mathrm{CP}$, incapaces de formar viriones, seguían generando túbulos (Kasteel et al., 1993).

Esta característica de la MP del CPMV se ha observado más tarde en las MPs de otros géneros pertenecientes a familias de virus de plantas diferentes como Bromoviridae, Caulimoviridae, Sequiviridae, Bunyaviridae. En todos ellos, la MP sigue siendo el único requerimiento viral para la formación de los túbulos. Asimismo, algunos miembros de la familia Bromoviridae, como el Virus del mosaico del pepino (Cucumber mosaic virus, CMV), no precisan la formación del virión, aunque sí de un complejo entre el RNA viral y la CP, para su movimiento (Sánchez-Navarro y Bol., 2001; Sanchez-Navarro et al., 2006). La MP del TMV también es capaz de inducir la formación de túbulos, dado que se ha observado la formación de los mismos en protoplastos infectados con TMV aunque nunca en plasmodesmos de tejidos infectados (Heinlein et al., 1998). En este punto cabe recordar que el TMV se mueve en forma de complejo ribonucleoproteico sin requerir, como ocurre con los virus formadores de túbulos, la presencia de la CP para moverse célula a célula (Knapp et al., 2001). Experimentos recientes con virus quimera en los que el gen de la MP del AMV se ha reemplazado por los correspondientes genes del PNRSV, BMV, CMV, TMV o CPMV han puesto de manifiesto que todos los híbridos que portaban una extensión de 44 aminoácidos correspondiente al $\mathrm{C}$ terminal de la MP del AMV eran funcionales y que esta región es capaz de interaccionar específicamente con partículas virales del AMV in vitro (Sanchez-Navarro et al., 2006). Es de destacar que el reemplazamiento del gen de la CP por un gen mutante que codifica una CP defectiva en la formación del virión no afectó el transporte célula a célula de las quimeras con una MP funcional, demostrando claramente que las partículas virales no se requieren para el movimiento célula a célula mediado por las MPs del AMV, PNRSV, BMV, CMV, TMV o CPMV. La explicación más probable a estos resultados sería que los dos mecanismos descritos en la Superfamilia de las $30 \mathrm{k}$ pudieran representar dos variantes del mismo sistema de transporte viral en el que el $C$ terminal de la MP podría haberse adaptado para reconocer su "correspondiente" CP (Sanchez-Navarro et al., 2006). De este modo, es muy probable que esta regla también rija el movimiento de todos los virus que se mueven guiados por túbulos (ver revisión de Ritzenthaler y Hoffmann, 2007).

En la ruta de tráfico intracelular de las MPs formadoras de túbulos a los plasmodesmos cabría esperar al menos dos posibilidades: (i) la MP podría difundir desde su lugar de síntesis 
primero a la membrana plasmática y después a los plasmodesmos. Esta opción está sustentada en la observación de que el transporte de la MP del CPMV a los plasmodesmos no se ve afectada por tratamientos con drogas que desestabilizan los microfilamentos de actina (Latrunculina B), los microtúbulos (Orizalina) y la ruta secretora (Brefeldina A) (Powels et al., 2002). Sin embargo, el tratamiento con Brefeldina $A$ sí que inhibe la formación de los túbulos lo que sugiere que algún componente celular, transportado mediante esta ruta, es requerido para generar estas estructuras tubulares (Huang et al., 2000) (Figura 15 inferior) y (ii) la MP, y tal vez las partículas víricas, serían transportados a los plasmodesmos mediante su asociación con vesículas secretoras guiadas por microtúbulos y derivadas del aparato de Golgi (Figura 15 superior). Este mecanismo sería el propuesto para el GFLV, en el que el tratamiento con latrunculina $B$ y orizalina, aunque no inhibe la formación de túbulos, sí que provoca su creación en sitios ectópicos, además, la inhibición de la ruta de secreción provoca una reducción drástica en el número de túbulos así como una redistribución de la MP de los plasmodesmos al citoplasma (Laporte et al., 2003). En ambos casos, el ensamblaje de las MPs al generar los túbulos capturaría en su interior las partículas virales que serían liberadas en la célula adyacente tras la desestructuración de los túbulos (Figura 15).

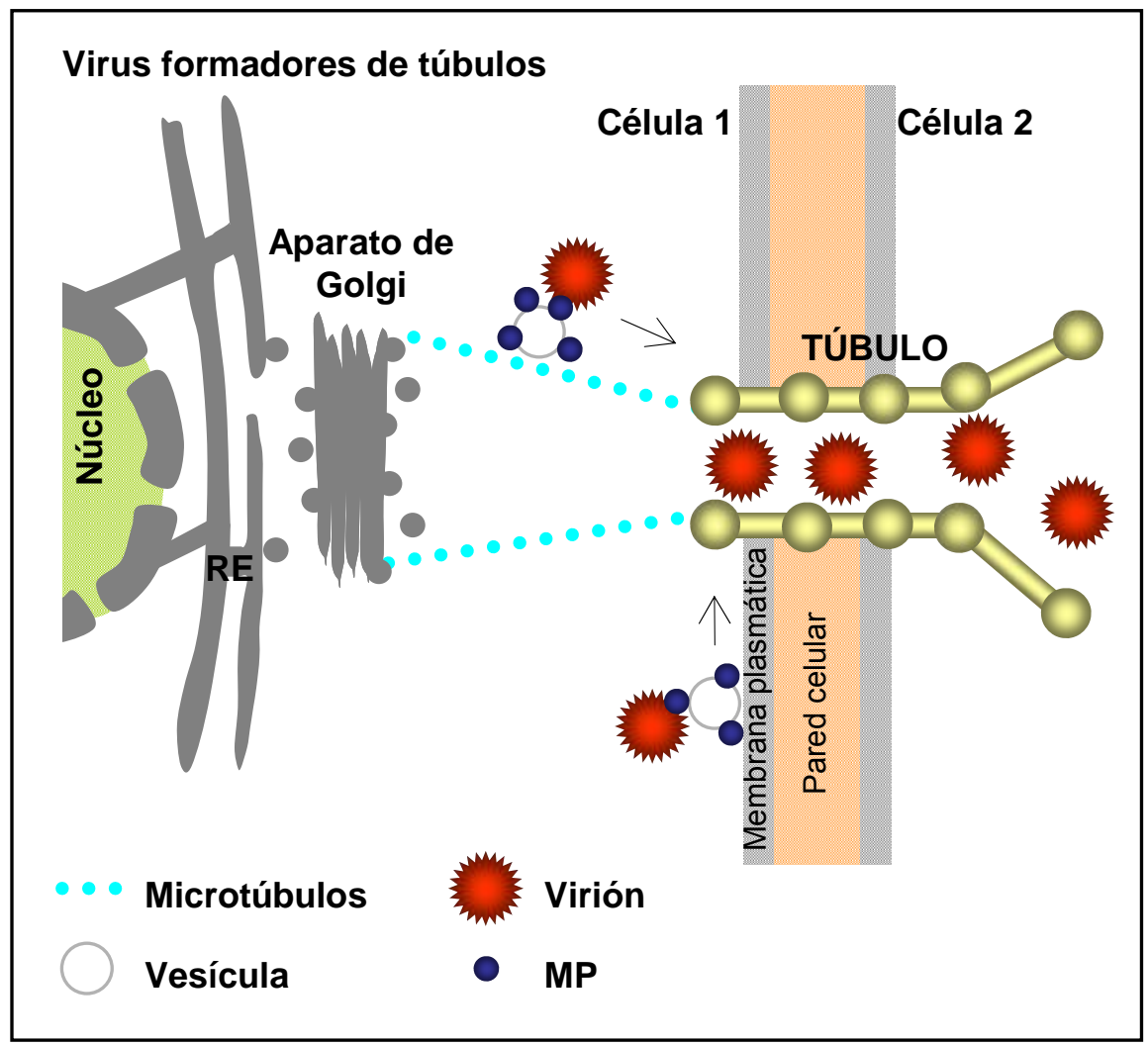

Figura 15. Modelos de transporte intracelular y célula a célula de los virus formadores de túbulos. En la parte superior de la figura se representa el modelo para el GFLV mientras que en la parte inferior se muestra el modelo para el CPMV. Ambos modelos confluyen en el plasmodesmo celular mediante la formación de estructuras tubulares de MPs o túbulos (ver revisión en Ritzenthaler y Hofmann, 2007). 
10.2.3 Movimiento de virus con el bloque de tres genes (Triple Gene Block, TGB). EI movimiento de los virus pertenecientes a este grupo requiere de la presencia de las tres proteínas del bloque de genes (TGBp1, TGBp2 y TGBp3). Como se ha comentado anteriormente, la comparación de la estructura primaria de estas tres proteínas nos permite diferenciar dos grupos virales diferentes: la clase 1 o los de tipo Hordeivirus y la clase 2 o los de tipo Potexvirus (Morozov y Solovyev, 2003). En ambos grupos, la proteína TGBp1, por estructura primaria, debería presentar una localización citoplasmática mientras que las TGBp2 y TGBp3 contienen secuencias hidrofóbicas requeridas para su asociación a membranas (ver apartado anterior). Cabe destacar que la CP sólo es necesaria para el movimiento, tanto célula a célula como sistémico, en los miembros del género Potexvirus, lo que indica que éstos podrían ser transportados como viriones o como complejos ribonucleoproteicos en los que participaría la CP. En cualquiera de los dos casos, esta situación genera diferencias entre los dos grupos de virus (Hordeivirus y Potexvirus) en cuanto a la composición del elemento viral móvil (Morozov y Solovyev, 2003).

La TGBp1, de forma similar a las proteínas de la Superfamilia 30k, es capaz de unir RNA/DNA simple cadena de forma cooperativa e inespecífica de secuencia y, tal y como se ha mencionado anteriormente, presenta un dominio helicasa en su secuencia. La TGBp1, dadas sus características, sería la encargada de trasportar el genoma viral al plasmodesmo. Sin embargo, existen determinadas diferencias funcionales, además de las estructurales, entre las TGBp1 de los dos grupos. Las TGBp1 del tipo Potexvirus son capaces de interaccionar autónomamente con el PD e incrementar su tamaño de exclusión molecular facilitando el tránsito del genoma viral a las células contiguas mientras que las del tipo hordeivirus no pueden modificar el SEL y necesitan de la TGBp2 y la TGBp3 para alcanzar los PD, siendo estas dos proteínas de membrana las que poseen la capacidad de aumentar el diámetro de este microcanal celular (Figura 16) (Howard et al., 2004, Zamyatnin et al., 2004). Además, las TGBp1 de los Potexvirus también pueden actuar como supresores del VIGS puesto que impiden la propagación de la señal móvil del silenciamiento génico (Voinnet et al., 2000).

Tal y como se ha mencionado anteriormente la TGBp2 y la TGBp3 son proteínas asociadas a membrana. La proteína TGBp3 es capaz de dirigir el tráfico de la TGBp2 desde los túbulos que forman la red cortical del RE a vesículas móviles que se dirigen y concentran en la periferia celular (Figura 16). El movimiento de dichas vesículas es dependiente de la red de microfilamentos de actina y se bloquea por el tratamiento con drogas que desestructuran la misma. En este punto, es importante destacar que en plantas superiores las vesículas del aparato de Golgi son transportadas a través de los microfilamentos de actina (ver apartado 8.1). Con estas premisas, sería posible que las proteínas del TGB utilizasen el aparato de Golgi y la red del trans Golgi en su movimiento hacia el plasmodesmo. Sin embargo, estas vesículas no colocalizan con marcadores celulares de este orgánulo ni el tratamiento con Brefeldina A tiene efectos sobre su localización o movimiento. De esta forma, es probable que el movimiento del complejo del TGB hacia el plasmodesmo se dé a través de la proliferación de estructuras 
vesiculares derivadas directamente del lado cortical del RE y que TGBp3 es capaz de inducir (Zamyatnin et al., 2002; Gorshkova et al., 2003; Haupt et al., 2005).

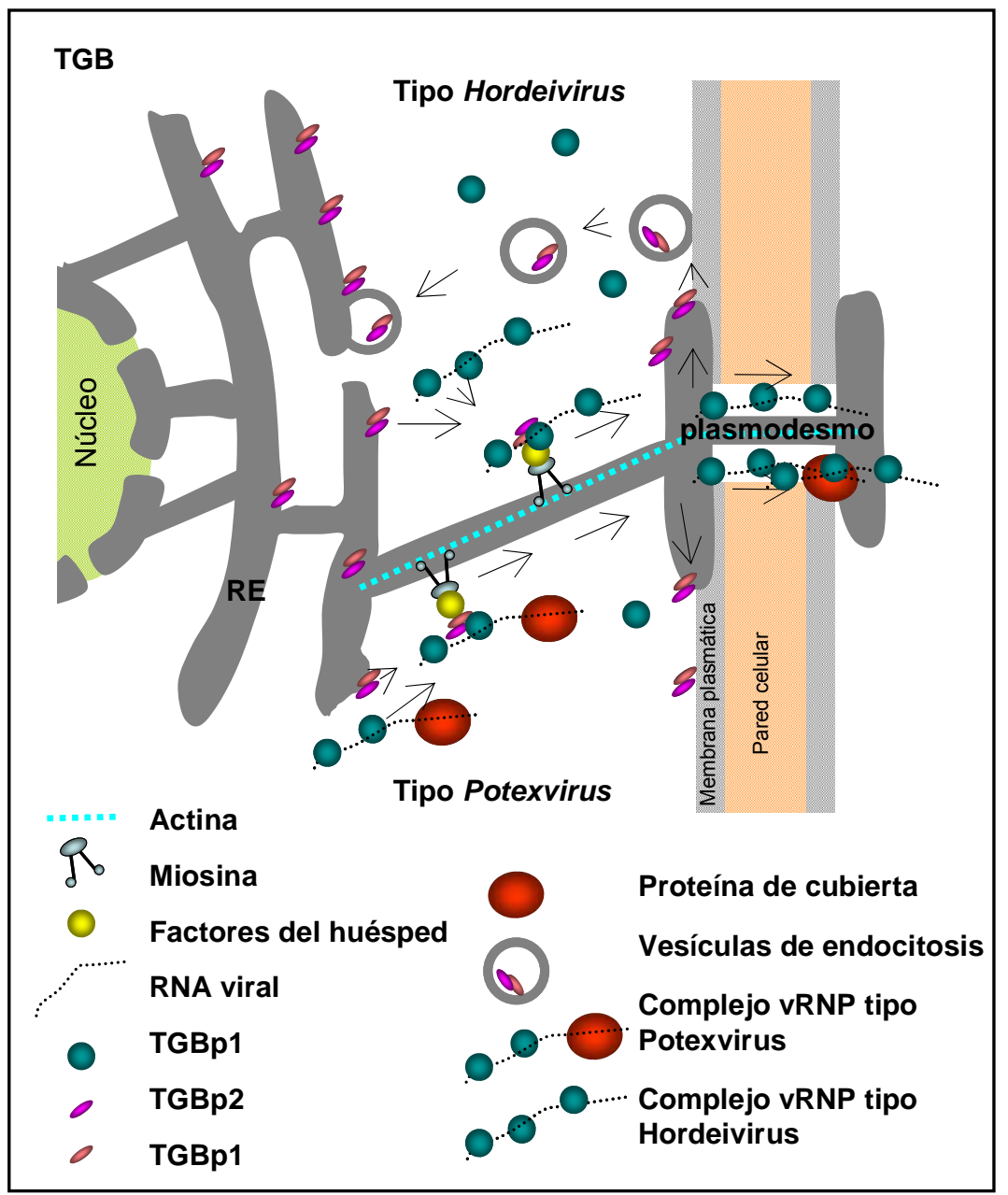

Figura 16. Posibles rutas intracelulares seguidas por proteínas virales del bloque de tres genes (TGB) en su camino a la periferia celular. Se trata de un sistema de varios componentes virales, para los que se han descrito características bioquímicas diferentes para las tres proteínas de movimiento así como dos posibles mecanismos: el tipo Potexvirus (abajo), con la implicación de la proteína de cubierta y el tipo Hordeivirus (arriba), donde se vería implicada la ruta endocítica celular (ver revisión en Morozov y Solovyev, 2003).

Además, ya en la membrana plasmática, ambas proteínas se localizan también en estructuras punteadas ricas en depósitos de callosa que podrían corresponderse con los plasmodesmos. En el caso del los Hordeivirus y en estadios tardíos de la infección, la TGBp2 es capaz de conducir a la TGBp3 a vesículas de endocitosis entrando las dos proteínas en una ruta de reciclado hacia el interior celular (Figura 16) (Solovyev et al., 2000; Zamyatnin et al., 2002; Haupt et al., 2005). En esta dirección, la TGBp3 contiene un motivo conservado YQDLN en su dominio citoplasmático del tipo YXXH (siendo $\mathrm{X}$ cualquier aminoácido y $\mathrm{H}$ un aminoácido hidrofóbico). Se ha descrito en virus animales que estos motivos favorecen la entrada en la célula por endocitosis. Además, experimentos de mutagénesis revelan que la los residuos Y y L presentes en estos motivos están implicados en la localización subcelular de la proteína en el 
$\mathrm{RE}$, en las vesículas móviles y en los plasmodesmos (Solovyev et al., 2000; Zamyatnin et al., 2002; Laporte et al., 2003; Haupt et al., 2005). Por último, se ha demostrado la interacción entre TGBp2 y TGBp3 con el sistema del doble híbrido en levaduras (Cowan et al., 2002).

Resumiendo, en el modelo de transporte intra- e intercelular para este tipo de virus se propone que TGBp1 interacciona con el RNA viral transportándolo como un complejo rionucloeproteico (compuesto de RNA-TGBp1 para el tipo Hordeivirus y RNA-TGBp1-CP para el tipo Potexvirus). Las proteínas TGBp2 y TGBp3 actuarían facilitando el transporte del vRNP en el interior celular y a través del plasmodesmo.

\subsection{Transporte sistémico de virus de plantas.}

Hoy en día, en comparación con el movimiento célula a célula, existe un menor conocimiento de los mecanismos que subyacen al movimiento sistémico. El movimiento sistémico o a larga distancia de los virus de plantas comienza con la entrada del virus en el tejido vascular, generalmente el floema, de la planta huésped. En este proceso podemos diferenciar hasta cinco pasos secuenciales y diferentes (Figura 17): (i) la entrada del virus en el parénquima vascular (Vascular parenchyma, VP) a través de las células de la vaina (Bundle sheath, BS); (ii) la traslocación a las células acompañantes (Companion cell, CC) y los elementos cribosos (Sieve element, SE) del VP; (iii) el transporte hacia otros órganos de la planta a través de los SE; (iv) la descarga desde el complejo SE-CC al VP no infectado y (v) el transporte desde el VP a través de las BS a las células del mesófilo (Mesophyll cell, ME) de otros órganos sistémicos de la planta.

En general, la ultraestructura de los plasmodesmos que interconectan las células de la vaina y el parenquima floemático es similar a los que comunican las células del mesófilo. De acuerdo con esta observación, se ha demostrado que los plasmodesmos existentes entre las células de la vaina y las células del mesófilo no suponen una barrera significativa para el movimiento de los virus (Nelson y van Bel, 1998). Sin embargo, en la mayoría de los estudios realizados en venas menores siempre hay un mayor porcentaje de células del parénquima floemático infectadas con respecto a las células acompañantes, sugiriendo que incluso en plantas susceptibles la invasión de las células acompañantes es un paso limitante de la infección sistémica (Nelson y van Bel, 1998; Moreno et al., 2004). Además, se sabe que los factores del huésped que interaccionan con las proteínas virales y ácidos nucleicos son diferentes a aquellos que están implicados en el movimiento célula a célula en el mesófilo. Por tanto, los mecanismos de transporte del movimiento célula a célula y a larga distancia han de ser significativamente distintos (Carrington et al., 1996; Nelson y van Bel., 1998).

Por otro lado, exceptuando los virus que se transportan por el xilema, todos los demás deben entrar desde las células acompañantes a los elementos cribosos del floema a través de la ruta simplástica. Los plasmodesmos que conectan el complejo CC-SE presentan características morfológicas diferentes, al estar especializados en el transporte de 
macromoléculas y presentar un SEL bastante alto. Por tanto, una vez han alcanzado las CC, los virus potencialmente tienen acceso directo al floema (Kempers et al., 1993; Kempers y van Bel, 1997). Los posibles mecanismos por los cuales el virus o la molécula de ácido nucleico entra en los SE son hasta ahora especulativos. Se ha descrito que tal vez el ácido nucleico del virus requiera la formación de un complejo con las MP o la CP, el cual se movería a través del plasmodesmo del SE acompañado por factores del huésped. Una vez en el SE, este complejo podría interaccionar con proteínas endógenas para estabilizarlo durante su transporte a larga distancia (Gilbertson y Lucas, 1996). Así pues, una vez el virus ha entrado en el floema éste es transportado junto al flujo de fotoasimilados (Scheneider, 1965) desde el tejido fuente al tejido sumidero por lo que el virus se mueve a una velocidad elevada comparable a la del tránsito de estas macromoleculas. El transporte sistémico estaría influenciado, por tanto, por los mismos patrones que regulan el flujo fotosintético, por lo que, la velocidad y dirección de este transporte depende de la fuerza relativa fuente-sumidero, la proximidad de la fuente al sumidero y las interconexiones del sistema vascular (Patrick, 1991). Sobre la forma en que el virus se trasloca a través del floema apenas sí existen datos aunque se asume que en la mayoría de los casos el virus se transportaría en forma de virión. Sin embargo, se ha observado la posible implicación de diferentes proteínas floemáticas que interaccionarían y facilitarían la traslocación tanto de virus de RNA (Requena et al., 2006) como viroides (Gomez y Pallas., 2001; Owens et al., 2001; Gomez y Pallas., 2004; Gomez et al., 2005). Si estas proteínas participan de manera generalizada en la traslocación de estos virus es una cuestión todavía sin resolver.

De forma esquemática, los virus de plantas, al igual que los fotoasimilados, se dirigen desde el tejido maduro (fuente) hacia el tejido joven (sumidero) más cercano, que está creciendo activamente y que está directamente conectado por el sistema vascular. Así, los factores y condiciones que modulan el desarrollo de una planta condicionan totalmente la forma en la que el virus le invade y su distribución final en la misma. Del mismo modo, las condiciones ambientales bajo las cuales las plantas crecen antes de la inoculación, en el momento de la inoculación y durante el desarrollo de la enfermedad pueden tener profundos efectos en el curso de la infección. Además, la influencia de la disposición filotáctica de las hojas respecto del sitio de entrada de los virus así como el estado fenológico de la planta en el momento de la misma se ha demostrado tanto para virus DNA (Leisner et al., 1992) como para virus RNA (Más y Pallás, 1996).

En plantas con diferenciación anatómica del floema como en el caso de Cucurbitaceas y Solanaceas, se ha puesto de manifiesto que los virus se mueven hacia la raíz a través del floema externo de tallo, pero utilizan el floema interno para su movimiento hacia la parte aérea apical (Gosalvez-Bernal et al., enviado). En cualquier caso, determinados órganos de la planta, como el meristemo o los brotes apicales, permanecen libres de virus durante la infección (Gosalvez-Bernal et al., 2006). 
Disponemos de escasa información sobre la descarga de solutos desde el floema a los tejidos sumideros, aunque, en general, la descarga simplástica parece ser la más común (Fisher y Oparka, 1996). Estudios realizados en plantas de $N$. benthamiana infectadas con el PVX han demostrado que la descarga del virus es simplástica y ocurre a través de las venas mayores (Roberts et al., 1997). La infección de las venas menores sólo ocurre mediante el transporte célula a célula a través del mesófilo, debido probablemente a que estas venas menores en las hojas jóvenes se mantienen en un estado de desarrollo inmaduro y los SE están todavía indiferenciados o tal vez porque no existe continuidad simplástica en la unión entre las venas mayores y menores (Roberts et al., 1997).

Asimismo, los plasmodesmos disminuyen en número durante la transición sumiderofuente de la hoja, además de sufrir cambios estructurales, pasando de simples a ramificados. Los plasmodesmos ramificados que aparecen en las hojas fuente son los que constituyen un centro de control que determina qué tipo de moléculas pueden entrar al floema (Oparka y Turgeon, 1999), mientras que los plasmodesmos simples permitirían una rápida entrada de macromoléculas a la hoja en crecimiento (sumidero).

La implicación de la proteína de cubierta en el transporte sistémico se ha puesto de manifiesto para virus pertenecientes a los géneros Tobamovirus, Diantovirus, Tombusvirus, Geminivirus, Alfamovirus, Cucumovirus, Bromovirus, Luteovirus, Potexvirus y Potyvirus. Esta observación sugiere que para la mayoría de virus de plantas la CP puede actuar mediando el paso del virus al sistema vascular y que la formación del virión podría estar implicada en dicho proceso. Los Umbravirus constituyen una interesante excepción dado que no poseen CP y que se mueven sistémicamente en forma de complejo ribonucleoproteico.

Por otra parte, en algunos virus, la eliminación de la CP e incluso la disrupción de la capacidad de encapsidación, no eliminan la infección sistémica en determinados huéspedes. Por tanto, la encapsidación viral y la infección sistémica, no siempre van unidas. La CP desempeña un papel importante en la determinación de la especificidad de huésped, aunque el mecanismo por el cual ésta potencia el transporte sistémico es todavía desconocido.

En algunos virus, más allá de su papel en el movimiento local, las MPs pueden desempeñar un papel importante en el movimiento sistémico. Son ejemplos de proteínas de movimiento implicadas en ambos transportes la TGBp1 de Hordevirus y Potexvirus, o la MP del CMV. Al margen de las CPs y MPs, pueden estar implicados en el movimiento a larga distancia otros factores virales. Por ejemplo, la proteína $2 b$ de CMV y la p19 del Virus del enanismo ramificado del tomate (Tomato bushy stunt virus, TBSV) modulan el transporte viral, presumiblemente, por actuar sobre el mecanismo de silenciamiento génico postranscripcional (PTGS) (Moissiard y Voinnet, 2004). Así mismo, la replicasa de $126 \mathrm{KDa}$ del TMV, la proteínasa HcPro o la proteína asociada (VPg) del Virus del grabado del tabaco (Tobacco etch virus, TEV), también están implicadas en el transporte sistémico. 
Por último, determinados factores celulares pueden estar implicados en el movimiento de los virus, bien por actuar directamente regulando el transporte viral per se bien por actuar indirectamente a través del silenciamiento génico postranscripcional (PTGS) (Voinnet, 2001; Moissiard y Voinnet, 2004).

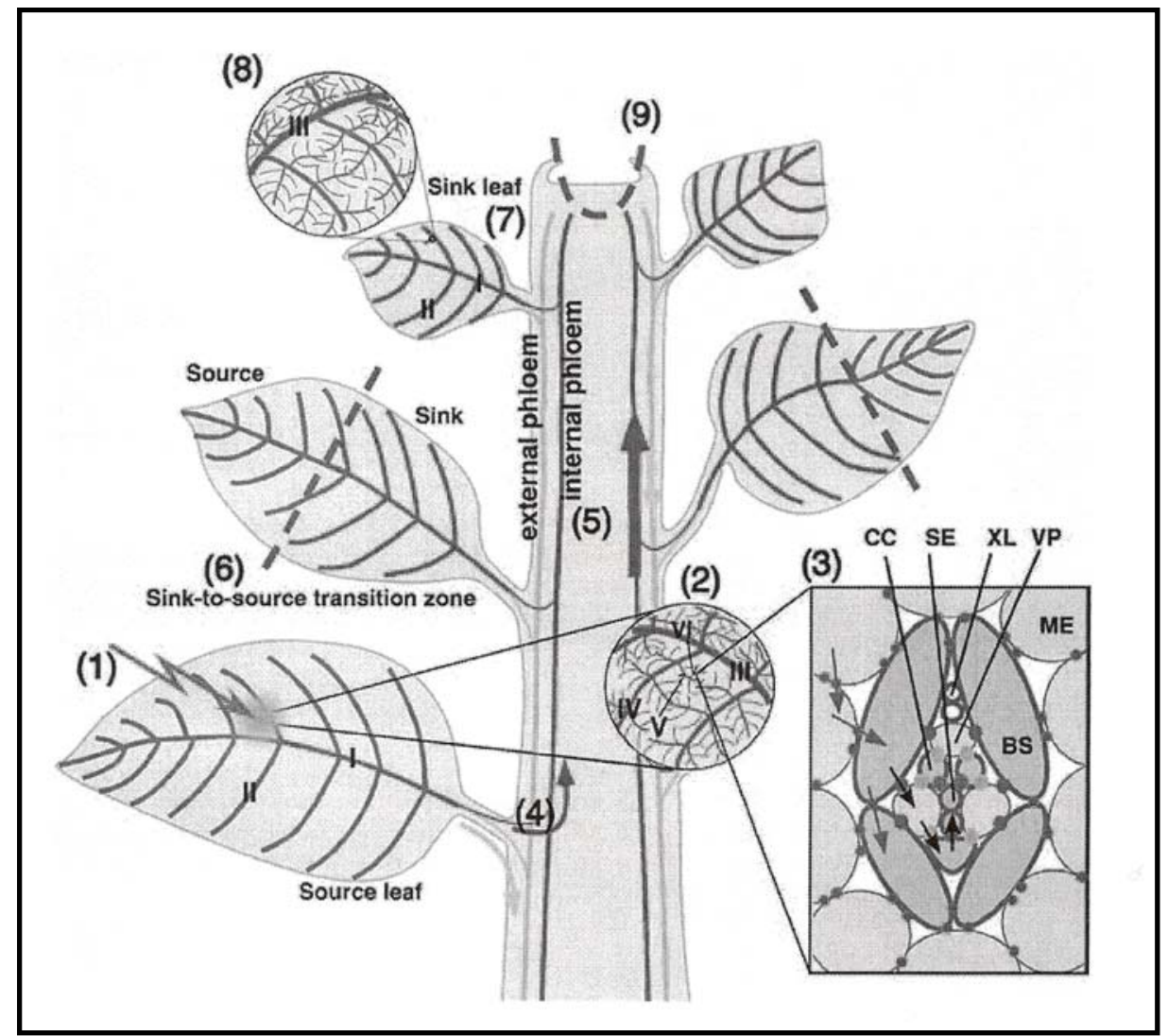

Figura 17. Rutas celulares del movimiento sistémico de los virus de plantas. $(1,2)$ Se representa una infección viral iniciada en las células del mesófilo de la hoja, desde donde el virus se mueve célula a célula hasta alcanzar el tejido vascular en el que entra a través de las venas mayores y menores (I-V). (3) Para entrar en el floema el virus debe atravesar las células del mesofilo (ME), las de la vaina (BS), el parenquima floemático (VP), las células acompañantes (CC) y llega a los elementos cribosos (SE). (4) Una vez en los tubos cribosos (SE) el virus saldrá de la hoja inoculada usando el floema adaxial y abaxial de las venas de la hoja, el cual conecta con el floema interno y externo del tallo, respectivamente. (5) El floema interno media el movimiento rápido hacia arriba del virus, el floema externo el movimiento lento hacia abajo. (6) Las hojas pasan de ser sumidero a fuente durante su maduración, marcando una barrera para la inavasión viral. $(7,8)$ Para la completa infección sistemica los virus se descargan desde el floema de hojas sumidero, lo que suele ocurrir desde las venas mayores. (9) El meristemo apical se mantiene aislado no permitiendo el transporte de los virus, así como el de otras macromoléculas. Adaptado de Waigmann et al., 2004. 


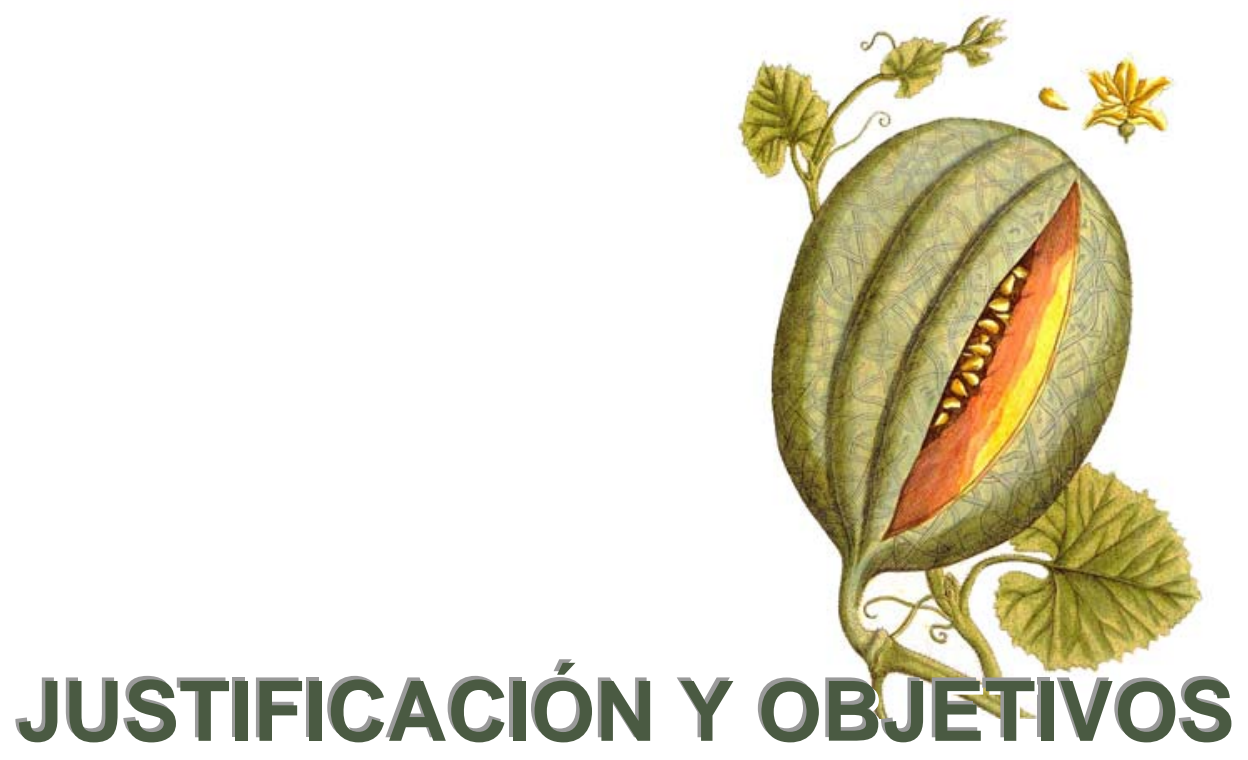


Los virus de plantas constituyen una seria amenaza para numerosos cultivos y suponen, por tanto, un importante problema económico para la agricultura. Aunque se ha avanzado mucho en el conocimiento de la estructura y los mecanismos de expresión de estos agentes infecciosos, se conoce menos sobre los procesos que operan en la invasión a los correspondientes huéspedes. En este contexto, se sabe que la resistencia de la planta a un virus puede deberse a la inhibición de la replicación viral, al bloqueo de su movimiento o al desarrollo de una respuesta hipersensible de la planta ante el patógeno. Asimismo, recientes investigaciones han puesto de manifiesto que el bloqueo del movimiento es la principal causa de resistencia a enfermedades virales. Por tanto, el éxito de una infección viral puede verse condicionado en muchos casos por la capacidad del virus de moverse desde su sitio de entrada en la planta. Consecuentemente, la comunidad científica está dedicando un gran esfuerzo en los últimos años en conocer las rutas celulares de invasión y movimiento de los virus de plantas y, en su aplicación más directa, en el desarrollo de estrategias de control de las mismas para posteriormente controlar las infecciones virales.

Los viriones del género Carmovirus tienen forma icosahédrica y están formados por unidades repetidas de la proteína de cubierta (CP) y un ácido nucleico, de entre 3879 a 4450 nucleótidos, de RNA simple cadena y polaridad positiva. Los Carmovirus codifican en su genoma hasta cinco pautas de lectura abierta (ORFs). En la región central del genoma se hallan los genes que codifican dos pequeñas proteínas de movimiento (MP). Observaciones recientes han demostrado que ambas proteínas son necesarias y suficientes para que se dé el movimiento intra- e intercelular de los Carmovirus. Se trata, por tanto, de un sistema idóneo para el estudio de las relaciones estructura-función en virus de plantas. En el presente trabajo se ha abordado el estudio funcional y de movimiento del virus de las manchas necróticas del melón (MNSV) como representante del genero Carmovirus. El MNSV fue descrito por primera vez en 1966 sobre plantas de melón cultivadas en invernadero (Kishi, 1966) y posteriormente en especies de cucurbitáceas en todo el mundo. La infección por MNSV da lugar a importantes pérdidas económicas debido a que las cucurbitáceas son uno de los principales cultivos hortícolas mundiales.

Aunque el mecanismo de expresión de los Carmovirus en general y del MNSV en particular se conoce desde hace tiempo, las rutas y/o requerimientos para su movimiento intra e intercelular han sido escasamente estudiados. En el presente trabajo se propuso como objetivo global avanzar en el conocimiento de los mecanismos y modo de acción del MNSV en su invasión intra e intercelular. Para ello, se plantearon los siguientes objetivos concretos:

1. Obtención de un clon infeccioso del MNSV (pMNSV-Al).

2. Análisis funcional de las proteínas codificadas en el genoma del MNSV.

3. Estudio de las propiedades de unión a RNA e inserción a membrana de las proteínas implicadas en el movimiento del MNSV, p7A y p7B.

4. Estudio del patrón de localización subcelular de p7A y p7B.

5. Aproximación a un modelo de movimiento intra- e intercelular de Carmovirus. 


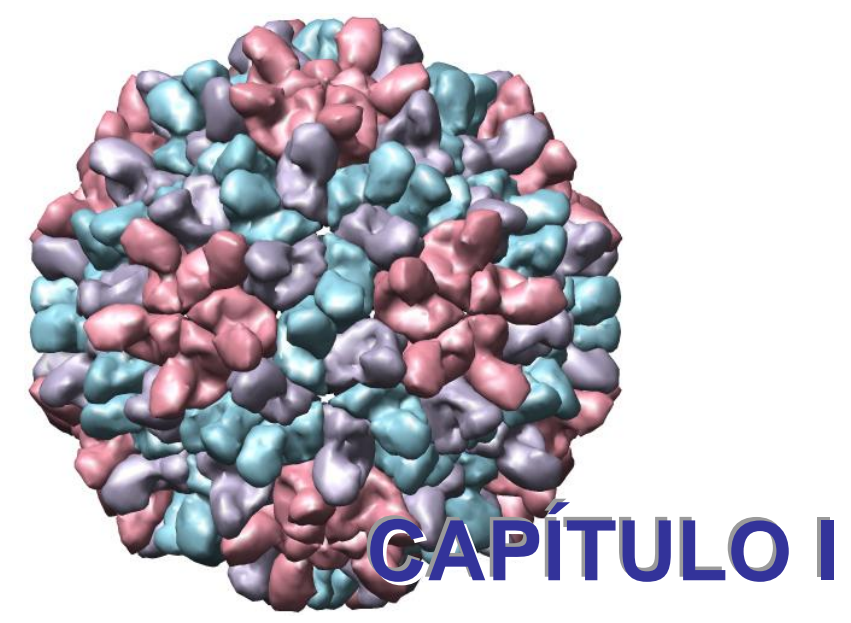




\title{
Functional analysis of the five Melon necrotic spot virus genome-encoded proteins
}

\author{
A. Genovés, J. A. Navarro, and V. Pallás \\ Instituto de Biología Molecular y Celular de Plantas (IBMCP). UPV-CSIC, Avda. de los \\ Naranjos, s/n, 46022, Valencia, Spain. \\ Journal of General Virology 87, 2371-2380.
}

\begin{abstract}
The Melon necrotic spot virus (MNSV) genome-encoded proteins (p29, p89, p7A, p7B and p42) function has been studied. Protein expression mutants from an infectious full-length cDNA clone of a Spanish MNSV-Al isolate and a recombinant GFP-expressing virus were used in infection bioassays on melon plants. Results revealed that p29 and p89 are both essential for viral replication whereas small proteins, p7A and p7B, are sufficient to support viral movement between adjacent cells operating in trans. We also demonstrated that, in addition to its structural role as coat protein, p42 is an important factor controlling symptoms and that it is required for systemic transport. Moreover, both p42 and p7B, among all the MNSV encoded proteins, were able to delay RNA silencing in transient expression assays on GFP-transgenic Nicotiana benthamiana plants. Finally, the presence of p42 also produced an enhancing effect on local spread similar to that of potyviral helper component proteinase (HC-Pro) most likely due to its RNA silencing suppression ability.
\end{abstract}




\section{INTRODUCTION}

Melon necrotic spot virus (MNSV) is a small $(\sim 30 \mathrm{~nm})$ isometric plant virus that has been classified into the genus Carmovirus within the family Tombusviridae (Hibi \& Furuki, 1985; Riviere \& Rochon, 1990). MNSV has a narrow range of host plants almost restricted to the species in family Cucurbitaceae. Characteristic symptoms of diseased plants include necrotic spots on leaves and stem necrosis. MNSV is naturally transmitted in soil by the zoospores of the chytrid fungus Olpidium bornovanus (Lange \& Insunza, 1977; Campbell \& Sim, 1994) when it attaches itself to the spore outer covering (Furuki, 1981). Once the virus invades the plant, it can be mechanically propagated during pruning or harvesting. Alternatively this virus may be seed propagated, although, in this case, efficient transmission requires the assistance of the fungal vector (Campbell et al., 1996).

The MNSV genome consists of a single-stranded, positive-sense RNA of approximately $4.3 \mathrm{~kb}$ (Riviere \& Rochon, 1990) and is thought not to be 5'-capped (Rochon \& Tremaine, 1989; Hearne et al., 1990; Huang et al., 2000). Several MNSV isolates have been cloned and sequenced (MNSV-Dutch, accession number NC_001504, Riviere \& Rochon, 1990; MNSV-NH and NK, accession numbers AB044291 and AB044292, Ohshima et al., 2000; MNSV-YS and KS, accession numbers AB189944 and AB189943, Kubo et al., 2005) and infectious transcripts have been obtained (MNSV-M 5 , accession number AY122286, Diaz et al., 2003; and MNSV264, accession number AY330700, Diaz et al., 2004). Molecular analysis of the MNSV genomic sequence revealed the presence of at least five open reading frames (ORFs) flanked by a short 5'-untranslated region (UTR) and a non-polyadenylated 3'-UTR. Interestingly, an avirulence determinant has been characterized in the 3'-UTR of isolate MNSV-264 allowing the infection of non-cucurbit species, in addition to overcoming the resistance conferred by the recessive gen nsv in melon (Diaz et al., 2004; Morales et al., 2005). The 5' proximal ORF has the potential to encode a protein of $29 \mathrm{kDa}$ (p29) terminating with an amber codon whose read-through would result in a larger gene product of $89 \mathrm{kDa}$ (p89). Two small centrally located ORFs encode two consecutive proteins of $7 \mathrm{kDa}$ (p7A and p7B). Interestingly, if read-through of the amber codon located at the end of p7A occurs, both proteins would be joined in-frame resulting in a fusion protein of $14 \mathrm{kDa}$. Finally, the $3^{\prime}$ proximal ORF codes for a coat protein of $42 \mathrm{kDa}(\mathrm{p} 42)$ which is related with those from the genus Tombusvirus (Riviere et al., 1989; Riviere \& Rochon, 1990; Cañizares et al., 2001). p29 and his read-through protein p89 are expressed from the genomiclength RNA (gRNA), whereas the small p7A and p7B (or p14) proteins and the coat protein are translated from 1.9 and $1.6 \mathrm{~Kb}$ subgenomic RNAs (sgRNAs), respectively (Riviere \& Rochon, 1990).

Each MNSV ORF function can be deduced from amino acid sequence comparisons with homolog proteins of other well-studied members of the same genus or family. Thus, p29 and p89 are most likely viral components of the replicase-transcriptase complex (Hacker et al., 
1992; White et al., 1995; Panaviene et al., 2003; Panavas et al., 2005). The two central ORFs, p7A and p7B could be involved in the cell-to-cell movement (Hacker et al., 1992; Li et al., 1998; Marcos et al., 1999; Cohen et al., 2000) and homologs of p42, independently of their structural function as coat protein, have been involved in systemic movement (Cohen et al., 2000), suppression of post-transcriptional gene silencing (PTGS) (Qu et al., 2003; Thomas et al., 2003; Ryabov et al., 2004; Meng et al., 2006) and attachment to the surface of fungus vector zoospores in natural transmission (McLean et al., 1994; Robbins et al., 1997; Kakani et al., 2001). However, the association between sequence information and biological function of viral proteins has not been demonstrated in the case of MNSV. Therefore, this study reports the synthesis of infectious transcripts corresponding to the MNSV genome of an Spanish isolate (MNSV-Al, Gosalvez et al., 2003) and the subsequent mutational analysis by reverse genetics to explore proposed functions of each potential genome-encoded protein during viral infections of melon plants, the natural MNSV host. Furthermore, recombinant virus delivering the green fluorescent protein (GFP) marker was used to monitor viral factors affecting the spread of infection. Additionally, the putative role of each gene product in suppression of PTGS was studied.

\section{MATERIALS AND METHODS}

\section{Virus isolation and construction of a full-length cDNA clone of MNSV-AI gRNA}

Nucleotide sequences of the 5'and 3' termini of MNSV-Al gRNA were obtained by 3'RACE of the corresponding dsRNA, which was isolated from leaves of Cucumis melo L. subsp. melo cv. Galia plants infected with MNSV-Al isolate (Gosalvez et al., 2003) as previously described (Astruc et al., 1996; Covelli et al., 2004) and purified after electrophoretic separation on polyacrylamide gels. Briefly, the dsRNAs were denatured, polyadenylated and reverse transcribed with a primer containing a $3^{\prime}-\mathrm{dT}_{25}$ tail with the last base degenerated. These modified RNAs were PCR amplified using oligo(dT) primer combined with others derived from internal regions of the isolate MNSV-Dutch. Five clones from each terminus were sequenced and used to design MNSV-Al specific primers corresponding to 5' and 3' UTR ends. T7 promoter sequence was included in the 5'-UTR specific primer. Full-length cDNA construction was performed by RT-PCR amplification of three overlapping regions covering the entire gRNA of MNSV-Al, using primers corresponding to both MNSV-Al termini combined with others based on the MNSV-Dutch sequence. The three fragments were assembled using single endonuclease restriction sites located at the MNSV-Al sequence and ligated in the pUC18 vector (MBI Fermentas, Germany) by standard sub-cloning strategies giving rise to the pMNSV(Al) clone. Therefore, any MNSV-Dutch specific sequences predetermined by the used primers were removed. All reverse transcriptase and amplification reactions were carried out using the RevertAid H Minus Moloney murine leukaemia virus (M-MuLV) Reverse Transcriptase 
(MBI Fermentas, Germany) and Vent DNA polymerase (New England Biolabs Inc., MA, USA), respectively, following manufacturer's instructions. PCR amplification conditions included an initial denaturation at $95^{\circ} \mathrm{C}$ for 5 min followed by 30 cycles of denaturation at $95^{\circ} \mathrm{C}$ for $40 \mathrm{~s}$, annealing at $60^{\circ} \mathrm{C}$ for $40 \mathrm{~s}$ and extension at $72^{\circ} \mathrm{C}$ for $2 \mathrm{~min}$.

\section{Construction of a recombinant GFP-MNSV(Al) clone}

The p42 ORF from the full-length clone pMNSV(Al) was replaced by the GFP ORF to generate the recombinant pMNSV(Al)- $\Delta \mathrm{cp}$-GFP clone. Nucleotides located between positions 2845 and 4000 corresponding to the almost complete p42 gene, were remove by reverse PCR strategies using primers VP598 and VP599 (Table A) leading to the pMNSV-Al- $\Delta$ cp clone. GFP ORF was PCR-amplified using the pEGFP-C3 vector as a template (Clontech Laboratories, Palo Alto, CA) and primer pair VP543 (5' GCGGCCGCGGTCGCCACCATGGTGAG 3', underlined endonuclease restriction site Notl) and VP551 (5' CACAGGGCCCCTACTTGTACAGCTCGTCCA 3', underlined endonuclease restriction site Apal). Subsequently, the GFP cDNA was ligated to pMNSV-Al- $\Delta \mathrm{cp}$ by the previously introduced Notl and Apal restriction sites and T4 DNA ligase (Promega), resulting in the translational fusion of the first nine amino acids of the p42 to the GFP ORF.

Table A. List of primers used for site-directed mutagenesis of pMNSV(Al) and pMNSV(Al)- $\triangle \mathrm{cp}-\mathrm{GFP}$

\begin{tabular}{|c|c|c|c|}
\hline Mutant & $\begin{array}{l}\text { Primer } \\
\text { pair }\end{array}$ & Position ${ }^{*}$ & Sequence $^{t}$ \\
\hline \multirow[t]{2}{*}{ 89(FS) } & VP594 & $886-924$ & 5' GGTCAACTAGGGGTGACTAGTAGGAGCTCGCTGGGTTC 3' \\
\hline & VP595 & $924-886$ & 5' GAACCCAGCGAGCTCCTACTAGTCACCCCTAGTTGACC 3' \\
\hline \multirow[t]{2}{*}{$7 \mathrm{~A}(\mathrm{FS})$} & VP662 & $2467-2499$ & 5' CAAACTAATC.TTCGAGAGAAGAAGTAAAGAACG 3'(Xhol) \\
\hline & VP663 & $2499-2467$ & 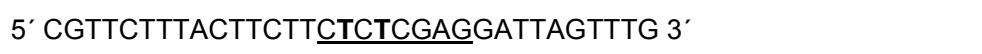 \\
\hline \multirow[t]{2}{*}{$7 \mathrm{~B}(\mathrm{FS})$} & VP596 & $2628-2669$ & 5' CTTTAACTTTTAGTGGATCCGCTTGTTGCCGTTGCGACTCC 3' (BamHI) \\
\hline & VP597 & $2669-2628$ & 5'GGAGTCGCAACGGCAACAAGCGGATCCACTAAAAGTTAAAG 3' \\
\hline \multirow[t]{2}{*}{$42(\mathrm{FS})$} & VP592 & $592-639$ & 5' CAAATGGCGATGGTTAGACGGATATCATAATTTACCCACAGTGAAGC 3' \\
\hline & VP593 & 639-592 & 5' GCTTCACTGTGGGTAAATTATGATATCCGTCTAACCATCGCCATTTG 3' \\
\hline \multirow[t]{2}{*}{$29(+)$} & VP646 & $876-916$ & 5' GCTTTCAAGTTGGTCAACTACGGGTGCCTAGAGGAGCTCGC 3' \\
\hline & VP647 & $916-876$ & 5' GCGAGCTCCTCTAGGCACCCGTAGTTGACCAACTTGAAAGC 3' \\
\hline \multirow[t]{2}{*}{$14(+)$} & VP598 & $2616-2663$ & 5' GGTGACTATTAACTTTAACTTTGCATGTATGGCTTGTTGCCGTTGCG 3' \\
\hline & VP599 & $2663-2616$ & 5' CGCAACGGCAACAAGCCATACATGCAAAGTTAAAGTTAATAGTCACC 3' \\
\hline
\end{tabular}

The nucleotide positions within pMNSV(Al) are indicated.

+ The boldface identifies the location of the nucleotide changes and underlined sequences are restriction sites introduced to facilitate the screening of mutants.

\section{Protein deficient expression constructs}

MNSV-Al protein deficient expression constructs used in this study are represented in Figure 1. Mutants were obtained from both the full-length pMNSV-Al and recombinant pMNSV(Al)- $\Delta$ cp-GFP clones by oligonucleotide-directed mutagenesis using the QuiKChangeR XL-Site Directed Mutagenesis Kit (Stratagene, La Jolla, CA) according to the manufacturer 
protocol and primer pairs listed in Table A. The plasmids series pMNSV(Al)-89(FS) and pMNSV(Al)- $\Delta \mathrm{cp}$-GFP-89(FS), pMNSV(Al)-7A(FS) and pMNSV(Al)- $\Delta c p-G F P-7 A(F S)$, pMNSV(Al)-7B(FS) and pMNSV(Al)- $\Delta c p-G F P-7 B(F S)$, in addition to pMNSV(Al)-42(FS) were obtained by introducing a frame-shift mutation in p89, p7A, p7B and p42 ORFs, respectively. A mutant virus allowing for the p89 read-through product expression but not the p29 protein, was generated by introducing an amber stop codon into a tyrosine codon mutation at the end of p29 ORF in the pMNSV(Al)-29(-) and pMNSV(Al)- $\Delta \mathrm{cp}-$ GFP-29(-) plasmids. Fusing p7A and p7B ORFs yielded the p14 expression by changing an amber stop codon into an alanine codon mutation at the end of p7A in the pMNSV(AI)-14(+) and pMNSV(Al)- $\Delta \mathrm{cp}-\mathrm{GFP}-14(+)$ plasmids.

(a)

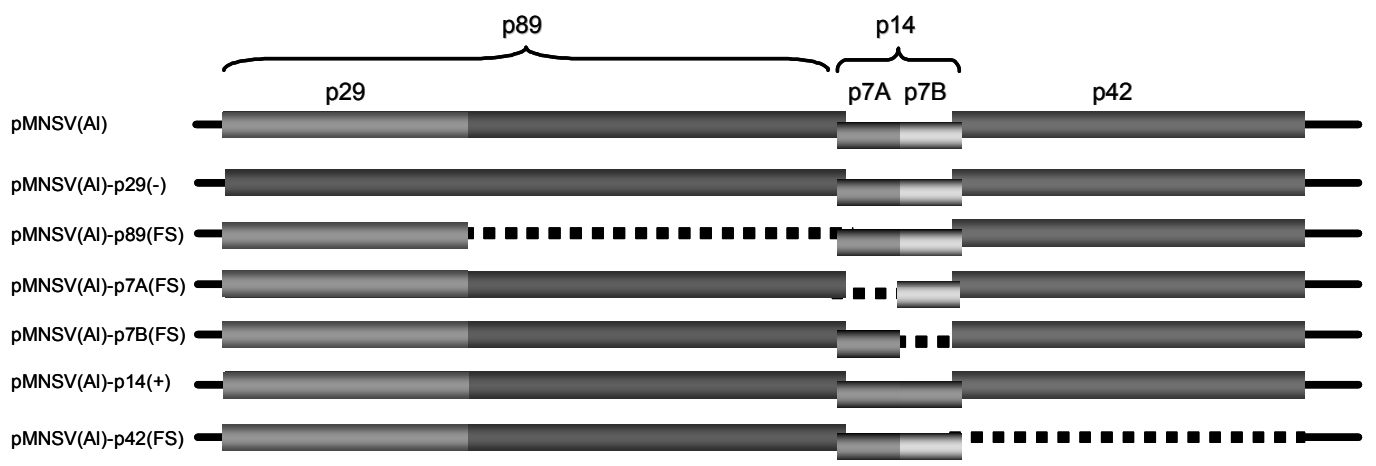

(b)

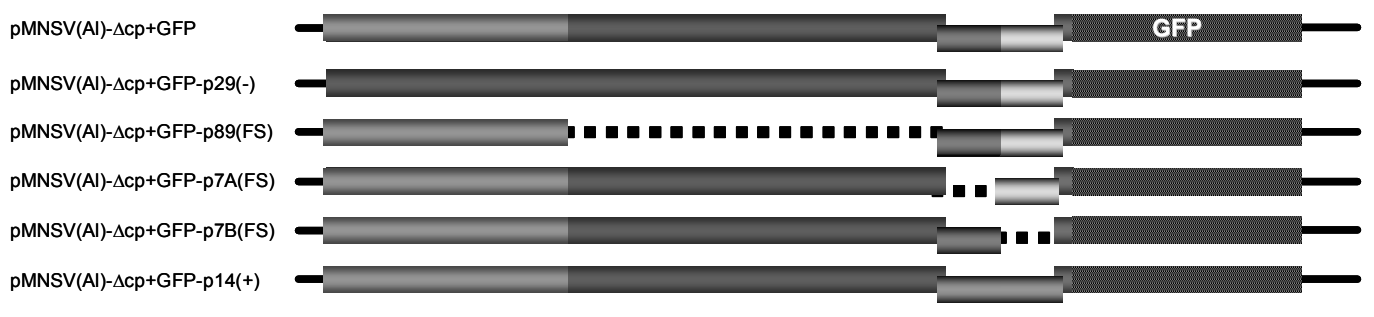

Figure 1. Schematic representation of (a) pMNSV(Al) and (b) pMNSV(Al)- $\Delta c p-G F P$ constructs and the corresponding protein deficient expression mutants. Names of putatively encoded proteins are shown at the bottom. GFP ORF is indicated in white letters. Non-modified coding regions are shown as open boxes, while frame-shift mutations are represented by discontinuous lines within diagrams or (FS) in construct name (left). Symbols (+) and (-) represent presence/absence of the protein indicated in the construct name, respectively.

\section{In vitro transcription and inoculation of plants.}

Plasmids were linearized by restriction with endonuclease Pstl. Non-viral nucleotides located at the 3'-end were removed by T4 DNA polymerase treatment and in vitro transcripts were synthesized by T7 RNA polymerase (Roche Diagnostics, Germany) standard reactions. Melon plants of 6-10-day-old were mechanically inoculated by rubbing fully expanded cotyledons with the uncapped transcription products (approximately $5 \mu \mathrm{g}$ RNA per cotyledon) in the presence of inoculation buffer (potassium phosphate buffer $0.03 \mathrm{M}, \mathrm{pH} 8$ ) and carborundum. Inoculated plants were kept in growth chambers with a $16 \mathrm{~h}$ day length, a daytime temperature of $25^{\circ} \mathrm{C}$, and a night time temperature of $22^{\circ} \mathrm{C}$. Total RNA from cotyledons were analyzed by Northern-blot and GFP expression was visualized with a TCS SL confocal laser scanning 
microscope (Leica, using filter BP/450-490 LP515) with excitation at $488 \mathrm{~nm}$ and emission at $500-535 \mathrm{~nm}$.

\section{Total RNA extraction, Northern-blot and Tissue-blotting assay}

Total nucleic acids extraction from either inoculated melon plant cotyledons or agroinfiltrated Nicotiana benthamiana leaves, was performed as previously described (Navarro et al., 2004). RNAs were electrophoresed through formaldehyde-denatured gel and transferred to positively charged nylon membranes (Roche Mannheim, Germany). Alternatively symptomatic cotyledons were crushed in the nylon membranes (Roche Mannheim, Germany) for Tissueblotting assay as described (Mas \& Pallas, 1995). Northern- and Tissue-blot membranes were air-dried and nucleic acids were bound using a UV cross-linker $\left(700 \times 100 \mu \mathrm{J} \mathrm{cm}^{-2}\right)$. Viral RNAs detection was carried out as previously described (Pallás et al., 1998) using a dig-riboprobe (Roche Mannheim, Germany) complementary to a region of MNSV-Al p42 ORF (Gosalvez et al., 2003) or to the complete GFP gene. Hybridization signals were quantified by densitometry analysis of film using 1-D manager ver.2.0 software.

\section{Binary constructs and Agrobacterium tumefaciens-mediated transient expression assays}

cDNAs corresponding to all putative MNSV-Al ORFs (p29, p89, p7A, p7B, p14 and p42) the modified p42 ORF containing the aforementioned frame-shift mutation for pMNSV(Al)42(FS), the complete MNSV-Al genome and the helper component proteinase ORF (HC-Pro) from Tobacco etch potyvirus (TEV) were cloned between the cauliflower mosaic virus (CaMV) $35 \mathrm{~S}$ promoter and the terminator sequence of the Solanum tuberosum proteinase inhibitor II gene (PoPit) in the binary vector pMOG800 (Knoester et al., 1998). These clones were named pMOG29, pMOG89, pMOG7A, pMOG7B, pMOG14, pMOG42, pMOG42(FS), pMOG-MNSV(Al) and $\mathrm{pMOG}(\mathrm{HC}-\mathrm{Pro})$ indicating the cloned sequences.

The previously described binary constructs, pMOG(GFP) carrying GFP (Clontech) expression cassette, (Herranz et al., 2005) and the pMOG800 plasmid, were transformed to Agrobacterium tumefaciens strain $\mathrm{C} 58 \mathrm{C} 1$ by electroporation. Identification of viral silencing suppressors was performed by transient expression assay on GFP transgenic $N$. benthamiana (line 16c provided by D. C. Baulcombe; Ruiz et al., 1998) as previously described (Voinnet et al., 2000; Qu et al., 2003). Three leaves per plant (4 plants/construct) were infiltrated into the abaxial side of leaves with a bacterial suspension consisting of an $A$. tumefaciens strain carrying the construct pMOG(GFP) either alone or in combination (1:1 mixture) with each strain containing plasmids described before.

In the case of the trans-complementation of pMNSV(Al)- $\Delta \mathrm{cp}$-GFP mutants, fully expanded cotyledons of one week-old melon plants were agroinfiltrated following the same procedure described above for $N$. benthamiana. Plants were inoculated 4-5 days later with modified pMNSV(AI)- $\Delta \mathrm{cp}-\mathrm{GFP}$ transcripts. 


\section{RESULTS}

\section{Infectivity of MNSV-Al gRNAs produced in vitro.}

The complete nucleotide sequence of isolate MNSV-AI (DQ339157) revealed high nucleotide and amino acid identity with previously described MNSV strains (MNSV-Dutch, Riviere \& Rochon, 1990; MNSV-NH and NK, Ohshima et al., 2000; Ma5, Díaz et al., 2003; MNSV-264, Díaz et al., 2004; MNSV-YS and KS, Kubo et al., 2005). A full-length cDNA clone of MNSV gRNA including a T7 RNA promoter at the 5'-end (pMNSV-Al) was constructed to enable MNSV-Al gRNAs synthesis, without foreign sequences at the 3'-end. These viral transcripts produced a local and, occasionally, systemic infection in susceptible melon plants, independently of the presence of a cap analogue at the 5'-terminus, as occurred with biologically active clones of isolates MNSV-M 5 and MNSV-264 (Díaz et al., 2003 and 2004). Symptoms produced by inoculation of in vitro MNSV-Al transcripts and the systemic spread rate were identical to those observed when viral RNA isolated from virions or purified virions were inoculated (data not shown). Local chlorotic spots became necrotic lesions in the cotyledons at approximately 5-6 days post-inoculation. When systemic infection was developed new young leaves emerged almost completely filled with chlorotic spots.

\section{p42 is a pathogenicity determinant necessary for systemic infection.}

Frame-shift or non-stop codon mutations of the five viral ORFs were introduced into pMNSV-AI infectious clone. Run-off transcripts produced from these mutants and from the original pMNSV-Al clone (wild-type) were inoculated onto melon plant cotyledons. Neither local nor systemic symptoms were observed, even at $10 \mathrm{dpi}$, in melon plants inoculated with MNSV(Al)-29(-), MNSV(Al)-89(FS), MNSV(Al)-7A(FS) and MNSV(Al)-7B(FS) RNAs which had impaired the expression of p29, p89, p7A and p7B, respectively. Similar results, were obtained with RNAs from pMNSV(Al)-14(+) which lacked individual p7A and p7B but expressed both proteins fused as p14 (data not shown). However, MNSV(AI)-42(FS) RNAs, containing a frameshift mutation within $\mathrm{p} 42$, induced the appearance of local symptoms on inoculated cotyledons but never in emerging leaves, unlike the situation observed for wild-type transcripts. Local symptoms included chlorotic spots unlike the more severe necrotic lesions generated by infection with wild-type RNAs (Figure 2a). Thus, the viral RNAs distribution in both types of local symptoms was analyzed by tissue-blotting assay. Hybridization signals of at least 5 different experiments consistently revealed that in the absence of p42 infection foci size was smaller than those observed in wild-type infections (Figure $2 \mathrm{a}$ and below). No hybridization signal was detected when mock inoculated plant cotyledons were also assayed (data not shown). These data suggest that p42 is an important factor controlling symptoms which is required for systemic transport and that also enhances cell-to-cell movement.

Replication of mutants was analyzed by Northern-blot of equivalent amounts of total 
RNAs purified from all inoculated cotyledons. MNSV RNAs were detected only when MNSV(AI)42(FS) RNA was inoculated (Figure $2 b$, lane 8). No significant effect was observed with this mutation on either the accumulation level of viral RNAs or the synthesis of both sgRNAs when compared to those observed for the wild-type RNA or even for viral particles, indicating that the replication/accumulation is not affected detectably by the absence of p42 (Figure 2b, compare lane 8 with lanes 1 and 2). To study p42 function further a deletion mutant was constructed (pMNSV-Al- $\Delta \mathrm{cp}$ ) and tested for its replication ability. Inoculation of these truncated RNAs resulted in an asymptomatic infection where one gRNA and two sgRNAs of approximately 1.2 kb smaller than the corresponding wild-type RNAs were detected by Northern-blot hybridization (Figure 2b, lane 9). Furthermore, the accumulation levels of these MNSV-Al- $\Delta c p$ RNAs were comparable to what is found in wild-type infections. These results strongly suggest that symptoms depend on the presence of the p42 nucleotide coding region and the protein itself.

(a)
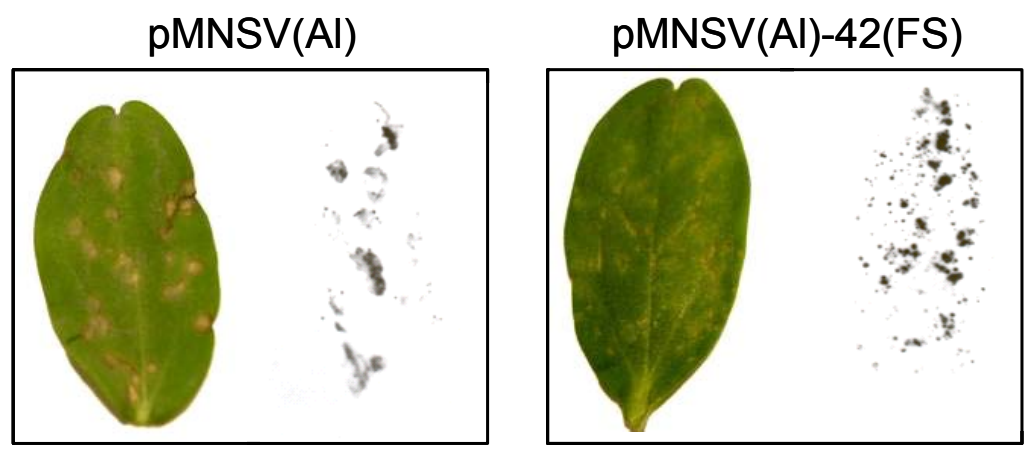

(b)
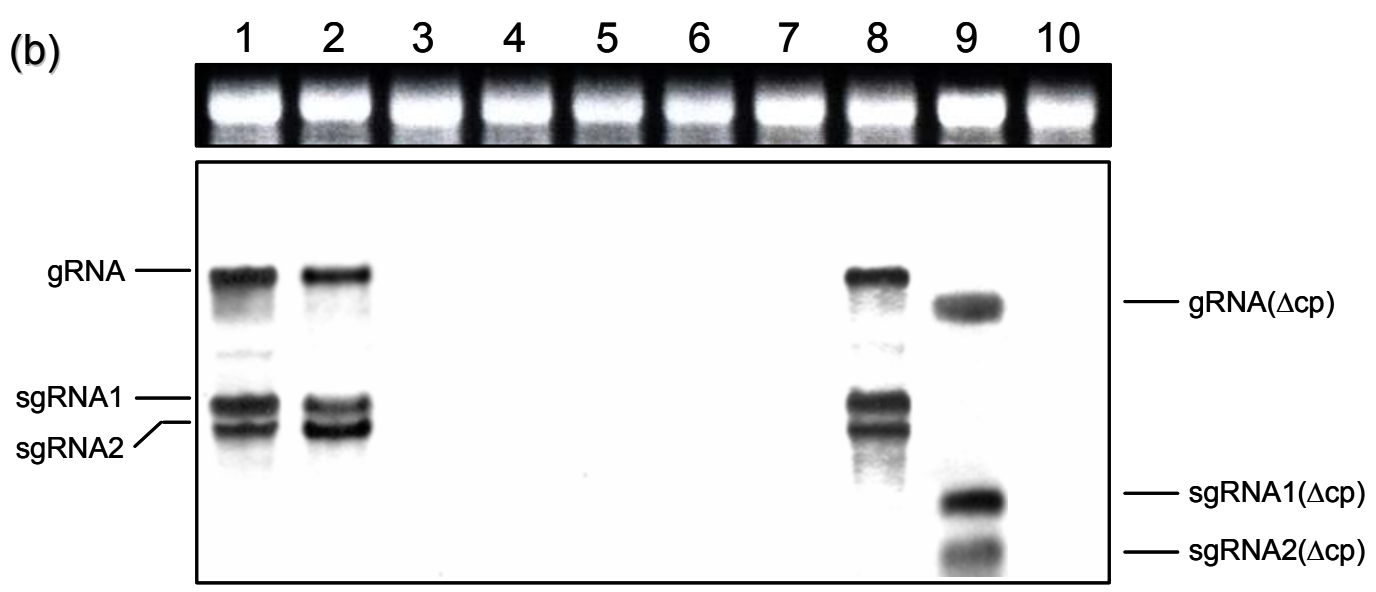

Figure 2. (a) Photographs of melon cotyledons showing local lesions produced by inoculation of transcripts of either pMNSV(Al) (left) or pMNSV(Al)-42(FS) (right). Corresponding Tissue-blotting is also shown beside both images. Assays were performed by using a p42 MNSV-specific riboprobe. (b) Detection by Northern-blot analysis of MNSV RNAs in melon plant cotyledons inoculated with purified virions (Lane 1) and in vitro transcripts of pMNSV(Al), pMNSV(Al)-29(-), pMNSV(Al)-89(FS), pMNSV(Al)-7A(FS), pMNSV(Al)-7B(FS), pMNSV(Al)-14(+), pMNSV(Al)-42(FS) and pMNSV-Al- $\Delta c p$ (Lanes 2-9, respectively). Total RNA extracts obtained from mock-inoculated plants were used as healthy controls (lane 10). MNSV genomic and subgenomic RNAs positions are indicated on the left. Relative sample loading is inferred from ethidium bromide staining of plant ribosomal RNA (bottom panel). 
p29 and p89 are essential in MNSV replication whereas cell-to-cell movement is controlled by the small p7A and p7B proteins.

A GFP-based approach commonly used to monitor virus infections (Baulcombe et al., 1995) was developed to differentiate between replication and cell-to-cell movement deficient mutants. Thus, a GFP-MNSV recombinant (pMNSV(Al)- $\Delta \mathrm{cp}-\mathrm{GFP}$ ) obtained by replacing the p42 ORF from the full-length clone pMNSV(AI) by the GFP ORF was constructed. GFP gene was fused in-frame with the first nine amino acids of the p42 ORF without affecting the p7B overlapping amino acids (Figure 1b). Transcripts derived from this chimeric construct (MNSV(Al)- $\triangle \mathrm{cp}$-GFP RNAs) were mechanically inoculated onto melon $c V$ galia cotyledons and GFP expression was monitored by confocal microscopy as green fluorescence. Three days post-inoculation, fluorescent infection foci were observed in inoculated cotyledons indicating that chimeric RNAs were able not only to replicate, since that GFP expression is only possible if the corresponding sgRNA 2 is synthesized, but also to move from cell-to-cell (Figure 3a). Systemic spread of the fluorescence was not detected and no symptoms were observed consistent with the results obtained before with $\mathrm{MNSV}(\mathrm{Al})-\Delta \mathrm{cp}$ RNAs.
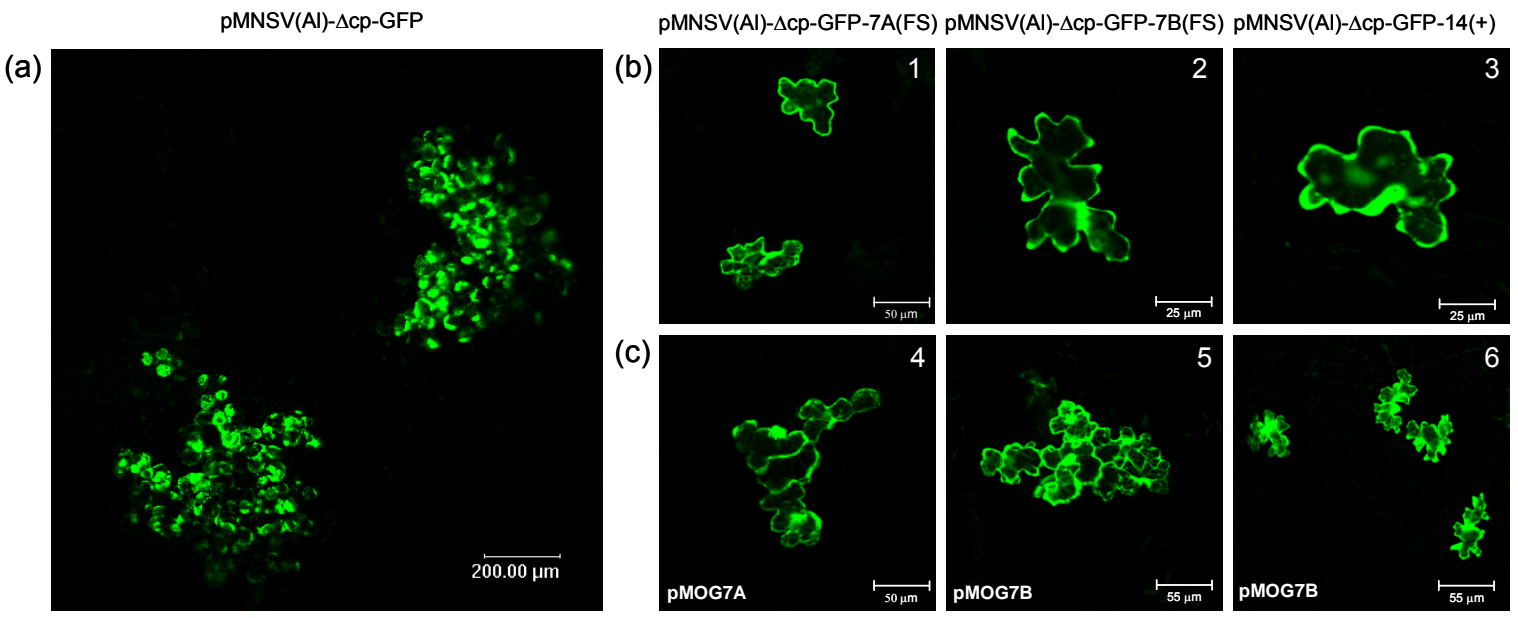

Figure 3. (a) Confocal imaging of infectious foci produced by inoculation of in vitro transcripts of pMNSV(AI)- $\Delta$ cp-GFP onto melon plant cotyledons. (b) Transcripts from pMNSV(Al)- $\Delta c p-G F P-7 A(F S)$, pMNSV(Al)- $\Delta c p-G F P-7 B(F S)$ and pMNSV(Al)- $\triangle \mathrm{cp}-\mathrm{GFP}-14(+)$ were inoculated onto melon plant cotyledons producing individual fluorescence cells (panels 1,2 and 3 respectively). (c) Images from complementation assays of MNSV movement mutants by transient expression. Complementation of MNSV(Al)- $\triangle \mathrm{cp}-\mathrm{GFP}-7 \mathrm{~A}(\mathrm{FS})$ or pMNSV(Al)- $\triangle \mathrm{cp}-\mathrm{GFP}-7 \mathrm{~B}(\mathrm{FS})$ RNAs by transient expression of p7A or p7B resulted in fluorescent cell groups (panels 4 and 5 , respectively). Complementation assay of MNSV(Al)- $\Delta \mathrm{cp}-$ GFP-14(+) RNA with p7A (panel 6) did not restore virus cell-to-cell movement capacity. All photographs were taken at 6 days post-inoculation.

We then made a set of pMNSV(Al)- $\Delta$ cp-GFP mutants, similar to those generated in pMNSV(Al) (Figure $1 \mathrm{~b}$ ) to discriminate between mutants that can not replicate from those that have their cell-to-cell movement impaired. Therefore, the modified MNSV(Al)- $\triangle \mathrm{cp}$-GFP RNAs were inoculated onto melon cotyledons and at 3,6 , and 8 days post-inoculation, a total of 100 cotyledons per construct were monitored for green fluorescence expression. RNAs from 
pMNSV(Al)- $\Delta$ cp-GFP-89(FS) and pMNSV(Al)- $\Delta$ cp-GFP-29(-), which were defective in the putative replicases p29 and p89 proteins, respectively, were unable to induce fluorescence (data not shown). Those from pMNSV(Al)- $\Delta \mathrm{cp}-\mathrm{GFP}-7 \mathrm{~A}(\mathrm{FS})$ and pMNSV(Al)- $\Delta \mathrm{cp}-\mathrm{GFP}-7 \mathrm{~B}(\mathrm{FS})$, which were defective in putative cell-to-cell movement proteins $\mathrm{p} 7 \mathrm{~A}$ and $\mathrm{p} 7 \mathrm{~B}$, respectively, led to GFP expression in individual cells (approximately 10 single cells/cotyledon) (Figure 3b, panels 1 and 2, respectively) until $8 \mathrm{dpi}$. Afterwards, the green fluorescence disappeared. Transcripts from pMNSV(Al)- $\Delta \mathrm{cp}-\mathrm{GFP}-14(+)$ provided similar results, indicating that viral RNA may not reach adjacent cells using the p14 fusion protein alone (Figure 3b, panel 3). These data strongly suggest that $p 29$ and p89 are essential for virus RNA replication while p7A and p7B are involved in cell-to-cell movement but most likely does not function as a p14 fusion protein.

Different complementation assays were performed to gain insight into the mechanism of cell-to-cell movement involving both p7A and p7B. Unlike the results reported for Turnip crinkle virus (TCV) in Arabidopsis thaliana (Li et al., 1998; Cohen et al., 2000), movement was not restored when RNAs from pMNSV(Al)- $\Delta c$-GFP-7A(FS) and pMNSV(Al)- $\Delta c p-G F P-7 B(F S)$ were inoculated together. Transgenic melon plants over-expressing MNSV proteins remain unavailable and experimental plants like $A$. thaliana or $N$. benthamiana are not MNSV host plants (except for isolate; MNSV-264; Diaz et al., 2003). Thus, we developed a different complementation approach using individual inoculation onto melon cotyledons of either MNSV(Al)- $\Delta \mathrm{cp}-\mathrm{GFP}-7 \mathrm{~A}(\mathrm{FS})$ or MNSV(Al)- $\Delta \mathrm{cp}-\mathrm{GFP}-7 \mathrm{~B}(\mathrm{FS})$ RNAs and providing each of the functional protein by transient expression using $A$. tumefaciens infiltration. Transient expression in melon plant cotyledons was previously assessed by agroinfiltration of binary vectors carrying GFP or p42 ORFs. Major expression of either GFP or p42, assessed as green fluorescence appearance or by Western-blot analysis, respectively, was observed at 5 days post-infiltration. Unlike in other experimental systems such as $N$. benthamiana, a non-uniform green fluorescence distribution among melon cotyledon cells was observed (Figure 4). Therefore, $10-$ days-old cotyledons were agro-infiltrated with binary vectors carrying non mutated $\mathrm{p} 7 \mathrm{~A}$ or $\mathrm{p} 7 \mathrm{~B}$ ORFs (pMOG7A and pMOG7B) and five days later, coincident with the peak of transient expression, they were inoculated with MNSV(Al)- $\Delta \mathrm{cp}-\mathrm{GFP}-7 \mathrm{~A}(\mathrm{FS})$ or MNSV(Al)- $\Delta \mathrm{cp}-\mathrm{GFP}$ $7 \mathrm{~B}(\mathrm{FS}) \mathrm{RNAs}$, respectively. A putative model involving $\mathrm{p} 7 \mathrm{~A} / \mathrm{p} 14$ or $\mathrm{p7B} / \mathrm{p} 14$ was evaluated by inoculating MNSV(AI)- $\triangle \mathrm{cp}-\mathrm{GFP}-14(+)$ RNAs onto either pMOG7A or pMOG7B agroinfiltrated cotyledons. A total of 50 cotyledons from each complementation assay were monitored by confocal microscopy. Individual cells and small fluorescent groups of cells were observed in similar proportions when MNSV(Al)- $\Delta c p-G F P-7 A(F S)$ and MNSV(Al)- $\Delta c p-G F P-7 B(F S)$ RNAs were complemented with the transient p7A expression (groups of no more than 3-4 cells) (Figure 3c, panel 4) and p7B (groups of no more than 6 cells) (Figure 3c, panel 5), respectively. By contrast, fluorescence was only detected in single cells in complementation assays performed with MNSV(Al)- $\Delta \mathrm{cp}-\mathrm{GFP}-14(+)$ RNAs, (Figure 3c, panel 6). Although we can not rule 
out the possibility that small foci originated by unconnected events of viral infection on adjacent cells this seems very unlikely since these results were never observed when movement mutants were inoculated onto pMOG800 agroinfiltrated cotyledons (data not shown). Both transiently expressed proteins, 7A and 7B, were able to complement in trans the corresponding mutant transcripts although the replicating mutant viruses never reached the levels of the infection foci produced when both movement proteins were provided by MNSV(Al)- $\triangle \mathrm{cp}-\mathrm{GFP}$ RNA (Figure 3a). This was probably because the agro-infection was not homogeneously distributed into the cotyledon as described before (Figure 4). Hence, the local spread of movement deficient RNAs was completely dependent on the location of the initially viral-infected cells inside a region expressing the corresponding movement protein. In addition, a new difficulty must be circumvented since proteins must be agro-expressed at levels able to support viral movement coinciding in time with the presence of the viral RNA inside the cell.
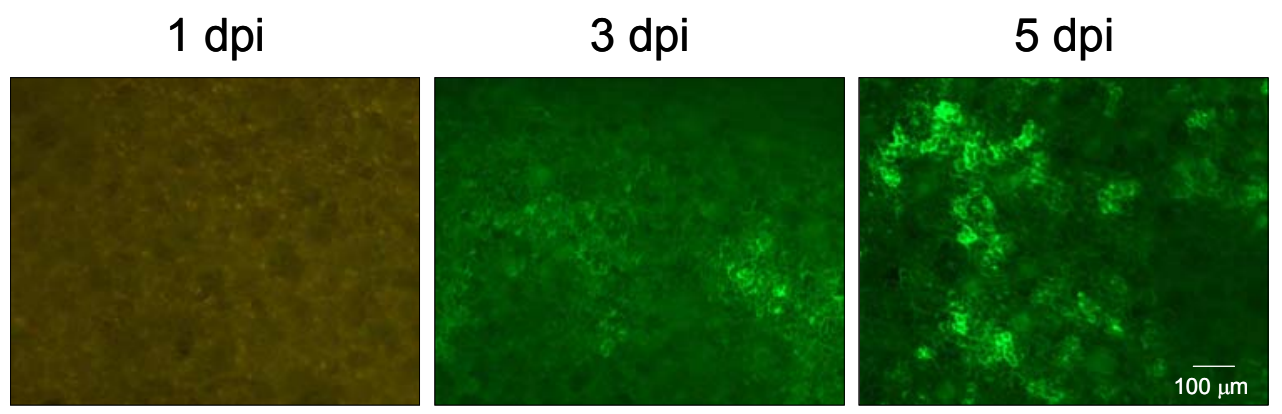

Figure 4. Magnificient images of abaxial-side of melon cotyledons taken at 1,3 and 5 days post agroinfiltration of pMOG(GFP) using Nikon's SMZ800 stereoscopic microscope under fluorescence illumination.

The MNSV movement protein p7B and the coat protein (p42) delayed RNA silencing in transient expression experiments.

A. tumefaciens-mediated transient expression assay on transgenic N. benthamiana plants expressing GFP (lane 16c; Ruiz et al., 1998) was performed as previously reported (Voinnet et al., 2000; Qu et al., 2003) to study the capacity of all MNSV genome encoded proteins to act as potential RNA silencing suppressors (see Methods section for detailed description of constructs). At $2 \mathrm{dpi}$, the transient GFP expression induced an evident increase of green fluorescence in all the infiltrated leaves when compared with the fluorescence observed in non agro-infiltrated (transgenically expressing GFP) or pMOG800 agro-infiltrated leaves (data not shown). As expected, the increase in GFP mRNA levels rapidly triggered the PTGS process in pMOG(GFP) agro-infiltrated leaves and, at $4 \mathrm{dpi}$, the fluorescence almost disappeared as a result of the specific GFP mRNA degradation (Figure 5a). 
(a)

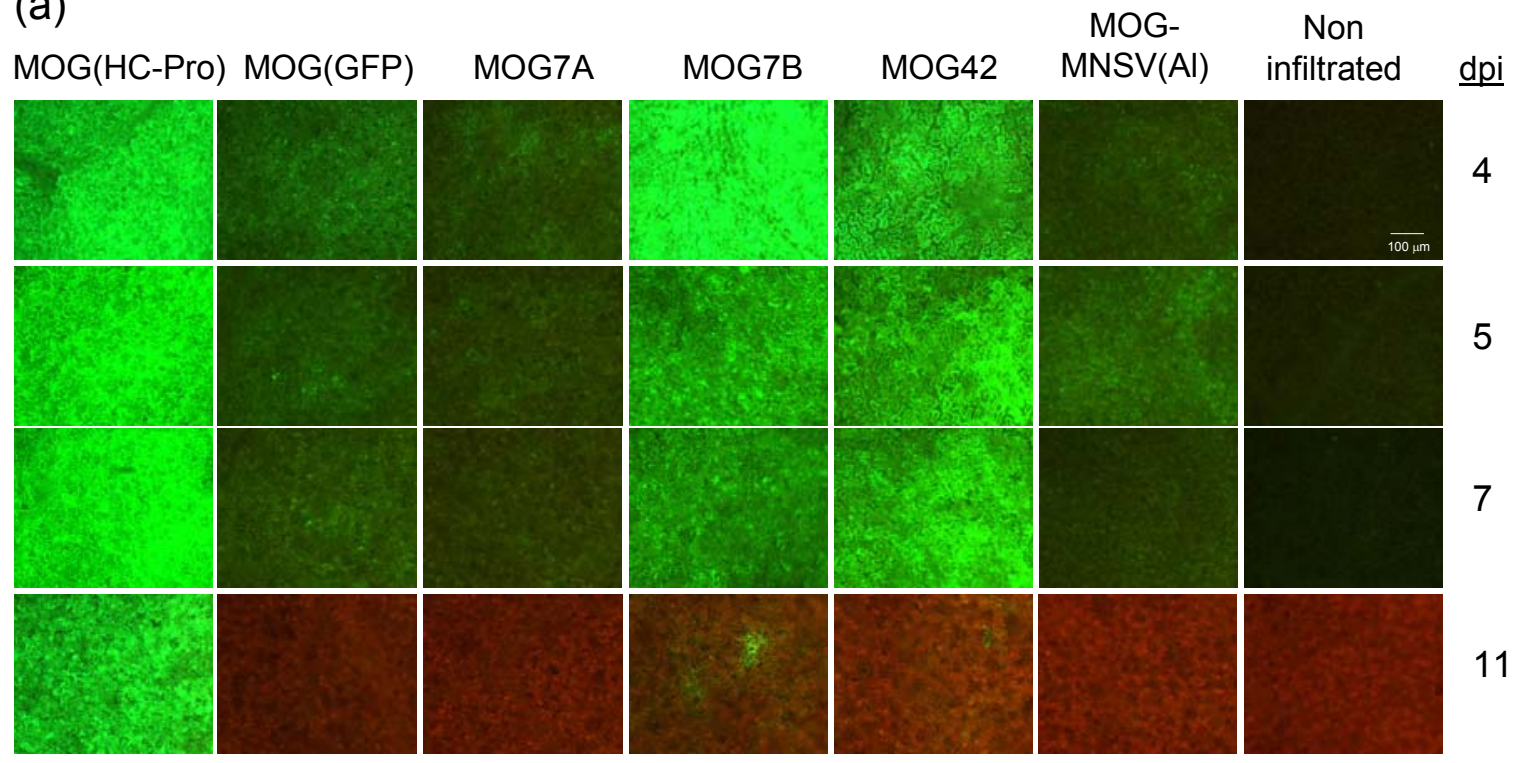

(b)

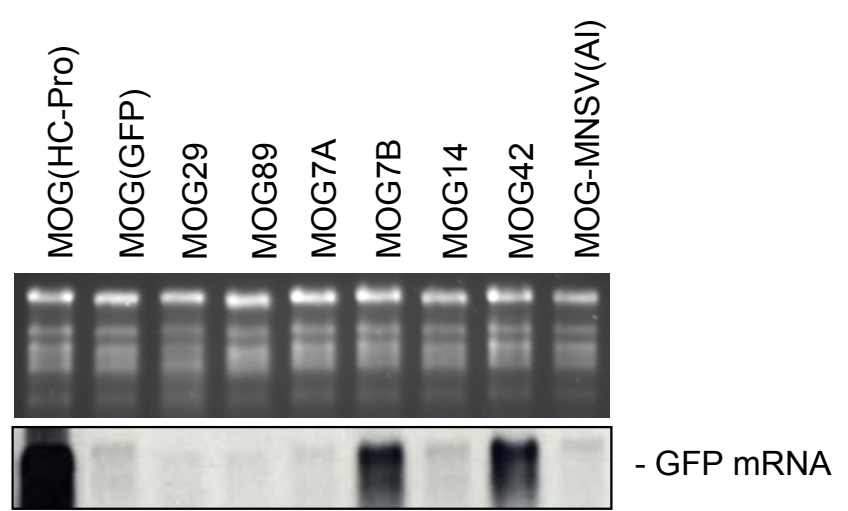

Figure 5. Identification of p7B and p42 as suppressors of RNA silencing by co-infiltration of $N$. benthamiana $16 \mathrm{c}$ plants with $A$. tumefaciens suspensions carrying the different MNSV-AI ORFs. Binary vectors delivering HC-Pro and GFP proteins were used as controls of presence and absence of RNA silencing suppression, respectively. (a) Green fluorescence images of abaxial-side of leaves taken at 4, 5, 7 and 11 days post-infiltration. Construct names are shown above the figure. Exposure time was $1 \mathrm{~s}$ except for pMOG HC-Pro (100 ms). (b) Northern-blot analysis of GFP mRNA levels in tissues co-infiltrated with different constructs (indicated on bottom). Relative sample loading is inferred from ethidium bromide staining of plant ribosomal RNA (top panel).

Nevertheless, when leaves were co-infiltrated with the mixture of bacterial strains carrying pMOG(GFP) and pMOG(HC-Pro) early GFP expression or GFP mRNA accumulation was much higher than in leaves infiltrated with $\mathrm{pMOG(GFP)}$ alone (Figure $5 \mathrm{a}$ and $5 \mathrm{~b}$, respectively). Moreover, fluorescence was maintained until $11 \mathrm{dpi}$ as expected for the activity of the potyviral HC-Pro, a strong RNA silencing suppressor (Kasschau \& Carrington, 1998; Anandalakshmi et al., 2000), and then, started to decline (Figure 5a). p7B or p42 proteins were able to delay complete GFP silencing at least up to seven days post-infiltration as monitored by green fluorescence intensity whereas the expression of MNSV-Al gene products p29, p89, p14 and p7A had no obvious consequence on PTGS (data not shown and Figure 5). This effect was clearly protein- rather than RNA-mediated since no PTGS suppression occurred when the MOG 
vector carried the complete MNSV-Al genome. Since $N$. benthamiana is a non-host of the MNSV-Al isolate, no sgRNAs are produced and p7A, p7B and p42 proteins are not expressed (Riviere \& Rochon, 1990) (Figure 5a). Therefore, expression of 7B as well as p42 contributed to the stabilization of GFP mRNA (Figure $5 \mathrm{~b}$ ) that further led to elevated GFP fluorescence (Figure $5 a)$. The effect of $p 7 B$ and $p 42$ proteins on GFP silencing was approximately 10-fold weaker than that generated by HC-Pro as measured by the GFP mRNA accumulation levels at 5 days post-infiltration (Figure 5b).

\section{MNSV coat protein (p42) and potyviral helper component proteinase (HC-Pro) favour local spread of MNSV(Al)- $\triangle$ cp-GFP RNAs.}

As demonstrated above, p42 shows a RNA silencing suppressor activity and it is involved in the final size that infection foci develop during MNSV invasion. To study the effect of this protein on viral local spread and comparing it with that of HC-Pro we performed a complementation strategy based on the transient expression assay. A. tumefaciens strains carrying pMOG800, pMOG42 or pMOG(HC-Pro) clones were agro-infiltrated into melon cotyledons. MNSV(Al)- $\triangle \mathrm{cp}$-GFP RNAs were inoculated at post-infiltration day 5. Local spread progress was assessed at $3,5,8,12$ and 14 days post-inoculation by monitoring green fluorescence. The differences observed from three independent experiments 8 cotyledons/assay) clearly demonstrated that the presence of p42 and HC-Pro produced an enhancing effect (higher in the case of HC-Pro) on infection foci size clearly obvious at $5 \mathrm{dpi}$. At this point, the diameter mean of infection foci in the presence of either p42 or HC-Pro was $750 \pm 53 \mu \mathrm{m}$ and $820 \pm 45 \mu \mathrm{m}$, respectively (Figure 6a, panels 1 and 2, respectively) whereas in the absence of both proteins was $300 \pm 13 \mu \mathrm{m}$ (figure 6a, panel 3). Additionally, viral RNA accumulation/replication rates were maintained when $\mathrm{p} 42$ or HC-Pro were expressed since all foci in infected cotyledons fused until the inoculated cotyledons were completely invaded at 14 days post-inoculation (data not shown). Unlike these results, the smaller fluorescence foci produced in the absence of both proteins continued to spread slowly until 8-10 dpi, and then spreading stopped and the fluorescence began to gradually decay (Figure 6b). Green fluorescence was never observed in vascular tissues. 
(a)

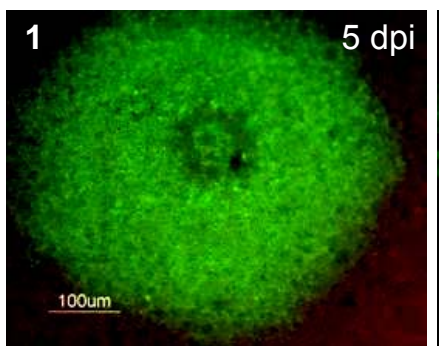

pMOG42

(b)

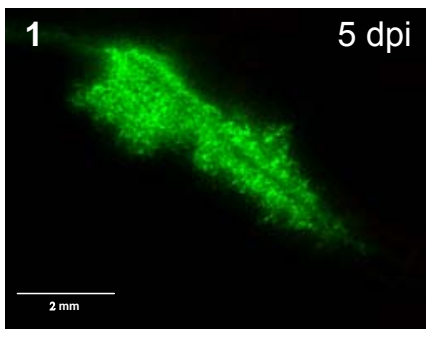

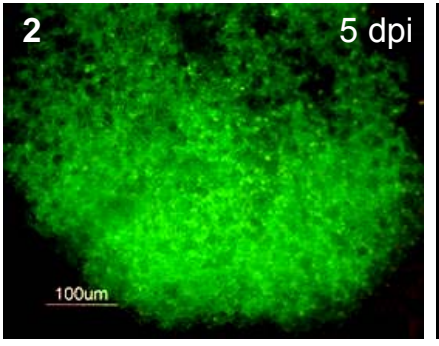

pMOG-Hc-Pro

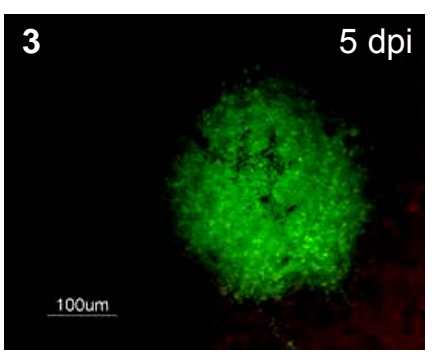

pMOG800

Figure 6. (a) Enhancing effect of transient expression of p42 (panel 1) or HC-Pro (panel 2) on infection foci size produced by MNSV(AI)- $\triangle$ cp-GFP RNA. Inoculation onto pMOG800 agro-infiltrated cotyledons was used as a control (panel 3). (b) MNSV(Al)- $\Delta$ cp-GFP RNA replication in absence of either p42 or HC-Pro. Photographs were taken at 5,8 and 12 days post-inoculation, as indicated. Fluorescent foci size increased until 8-10 dpi (panel 1 and 2), then, spreading stopped and brightness began to gradually decay (panel 3). Magnificent Images were taken by using Nikon's $\mathrm{SMZ}-800$ stereoscopic microscope.

\section{DISCUSSION}

Plant virus infection involves intracellular replication, movement from an infected cell to adjacent healthy cells by crossing the cell wall through the plasmodesmata and subsequently, long-distance spread to other plant parts via the vascular system. The accomplishment of this life cycle is also the consequence of antagonist balance between viral infection and plant host defence mechanisms that specifically target viral replication or movement (e. g. PTGS and systemic acquired resistance). In this work, we revealed the putative function of every MNSV encoded protein at each step of the infection, including replication, local and systemic movement as well as RNA silencing. To perform this study we used a mutational analysis by reverse genetics of both an infectious clone containing the whole genome of the isolate MNSV$\mathrm{Al}$ and a chimeric construct carrying GFP instead of p42 ORF. Firstly, the MNSV RNAs synthesis in inoculated melon plants was impaired when either p29 or p89 ORFs were inactivated in both series of mutants pMNSV(AI)-89(FS) and pMNSV(AI)-29(-) or pMNSV(AI)$\Delta$ cp-GFP-89(FS) and pMNSV(Al)- $\Delta$ cp-GFP-29(-). Consequently, these overlapping proteins are essential for MNSV replication and are probably part of the replication complex as has been described for related viruses such as TCV (Hacker et al., 1992; Rajedran et al., 2002) or 
Tomato bushy stunt virus (Rajendran \& Nagy, 2003; Panaviené et al., 2003; Rajendran \& Nagy, 2004; Panavas et al., 2005).

Following intracellular replication, cell-to-cell movement of carmoviruses (e. g. Cohen et al., 2000; Garcia-Castillo et al., 2003) seems to be controlled by two small proteins working in trans (Hacker et al., 1992; Li et al., 1998; Cohen et al., 2000), an RNA-binding protein (Marcos et al., 1999; Vilar et al., 2001) and a membrane protein (Vilar et al., 2002), referred to as double gene block proteins, DGBps (Hull, 2002). Interestingly, the homologous proteins from TCV have overlapping regions (Carrington et al., 1989) while MNSV-AI DGBps (p7A and p7B) are exceptional among sequenced carmoviruses since both proteins are arranged in-frame in such a way that a fusion protein consisting of complete p7A-p7B ORF (p14) could be synthesized by a read-through process (Riviere \& Rochon, 1990). However, the results reported here demonstrated that $\mathrm{p} 7 \mathrm{~A}$ and $\mathrm{p7B}$ operating in trans are sufficient to move viral RNAs among neighbouring cells of natural host plant. Complementation in trans of homologous TCV proteins was demonstrated on experimental plants (Li et al., 1998; Cohen et al., 2000), although indirect evidence was reported in the it natural host Brassica campestris (Hacker et al., 1992). p14 was, by contrast, unable to promote cell-to-cell movement even in the presence of either p7A or p7B. This last observation was also suggested by the presence of a strong termination codon at the end of p7A ORF that avoids p14 synthesis in isolate MNSV-Ma5 (Diaz et al., 2003). Consequently, if this protein is still expressed in some isolates, it is unlikely to play a role in local spread.

On the other hand, the absence of p42 led to localized infections as well as a reduced infection foci size even though it has been reported that coat proteins are dispensable for carmovirus cell-to-cell movement (type I movement, Scholthof, 2005). However, it is possible that these coat protein effects on local and systemic spread are associated with their RNA silencing suppression ability as suggested for other plant viral systems (Qu \& Morris, 2005). From data presented here and elsewhere, it is revealed that p42 has several functions throughout the MNSV life cycle. Primarily, this protein is responsible for the capsid structure (Riviere et al., 1989; Riviere \& Rochon, 1990), but it is also a pathogenicity determinant (protein that increase viral symptoms) enhancing local spread and an essential factor for systemic infection. Moreover, p42 and p7B are weak silencing suppressors since they delayed but did not prevent PTGS in transient expression experiments on GFP-transgenic plants. Nevertheless, similar results were observed for other plant viral suppressors when initially they were analyzed by using this transient expression method (p25 of Potato virus $X ;$ p20 and CP encoded by Citrus tristeza virus; Lu et al., 2004). Analogous combinations of p42 functions have been previously reported for other viral proteins potyviral HC-Pro; Cucumber mosaic virus $2 \mathrm{~b}$, including the related TCV coat protein (Brigneti et al., 1998; Qu et al., 2003; Thomas et al., 2003; Roth et al., 2004; Ryabov et al., 2004; Qu \& Morris, 2005). In this sense, p42 can contribute to development of lesions indirectly by facilitating virus replication and spreading. Interestingly and in parallel to 
our observations, with regard to the p7B component of the DGBp, a weak RNA suppressor activity was initially described in agro-infiltration experiments for Potato virus $X \mathrm{p} 25$, protein 1 from the triple gene block of proteins which are required for cell-to-cell movement of potexviruses (Voinnet et al., 2000; Lough et al., 2001). These data suggest that PTGS could be controlled by a component of the cell-to-cell movement machinery as a common feature among a number of plant viruses whose silencing suppression might be linked to viral transport (Verchot-Lubicz, 2005). Although, the PTGS mechanism stage (initiation, local or systemic spread of a silencing signal or maintenance) affected by both MNSV suppressors was not studied in this work, the transient expression of p42 was relevant at an early infection stage by stimulating cell-to-cell movement and maintaining RNA replication. However, further studies on melon transgenic plants or alternatively, the use of MNSV isolates infecting experimental plants (MNSV-264, Diaz et al., 2003) are necessary.

\section{ACKNOWLEDGEMENTS}

We thank L. Corachán for her technical assistance and Dr. D.C. Baulcombe for $N$. Benthamiana 16c plants. This work was supported by Grant BIO05-7331 from the grating agency DGICYT. J.A. Navarro and A. Genovés are recipients of an I3P contract and a PhD fellowship from the Consejo Superior de Investigaciiones Científicas and the Spanish Ministerio de Educacion y Ciencia, respectively. 


\section{REFERENCES}

Anandalakshmi, R., Marathe, R., Ge, X., Herr, J.M. Jr., Mau, C., Mallory, A., Pruss, G., Bowman \& L., Vance, V.B. (2000). A calmodulin-related protein that suppresses posttranscriptional gene silencing in plants. Science 290, 142-144.

Astruc, N., Marcos, J.F., Macquaire, G., Candresse,T. \& Pallás, V. (1996). Studies on the diagnosis of hop stunt viroid in fruit trees: Identification of new hosts and application of a nucleic acid extraction procedure based on non-organic solvents. Eur J. Plant Pathol 102, 837-846.

Baulcombe, D.C., Chapman, S. \& Santa Cruz, S. (1995) Jellyfish green fluorescent protein as a reporter for virus infections. Plant $\mathrm{J}$ 7,1045-1053.

Brigneti, G., Voinnet, O., Li, W.X., Ji, L.H., Ding, S.W. \& Baulcombe, D.C. (1998). Viral pathogenicity determinants are suppressors of transgene silencing in Nicotiana benthamiana. EMBO J 22, 6739-6746.

Campbell, R.N. \& Sim, S.T. (1994). Host specificity and nomenclature of Olpidium bornovanus (=Olpidium radicale) and comparisons to Olpidium brassicae. Can J Bot 72, 1136-1143.

Campbell, R.N., Wipf-Scheibel, C. \& Lecoq, H. (1996). Vector-assisted seed transmission of Melon necrotic spot virus in melon. Phytopathology 86, 1294-1298.

Canizares, M.C., Marcos, J.F., \& Pallas, V. (2001). Molecular variability of twenty-one geographically distinct isolates of Carnation mottle virus (CarMV) and phylogenetic relationships within the Tombusviridae family. Arch Virol 146, 2039-2051.

Carrington, J.C., Heaton, L.A., Zuidema, D., Hillman, B.I. \& Morris, T.J. (1989). The genome structure of Turnip crinkle virus. Virology 170, 219-226.

Covelli, L., Coutts, R.H., Di Serio, F., Citir, A., Acikgoz, S., Hernandez, C., Ragozzino, A. \& Flores, R. (2004). Cherry chlorotic rusty spot and Amasya cherry diseases are associated with a complex pattern of mycoviral-like double-stranded RNAs. I. Characterization of a new species in the genus Chrysovirus. J Gen Virol 85, 3389-3397.

Cohen, Y., Gisel, A. \& Zambryski, P.C. (2000). Cell-to-cell and systemic movement of recombinant green fluorescent protein-tagged Turnip crinkle virus. Virology 273, 258-266.

Diaz, J.A., Bernal, J.J., Moriones, E. \& Aranda, M.A. (2003). Nucleotide sequence and infectious transcripts from a full-length cDNA clone of the carmovirus Melon necrotic spot virus. Arch Virol 148, 599-607.

Diaz, J.A., Nieto, C., Moriones, E., Truniger, V. \& Aranda, M.A. (2004). Molecular characterization of a Melon necrotic spot virus strain that overcomes the resistance in melon and nonhost plants. Mol Plant Microbe Interact 17, 668-675.

Furuki, I. (1981). Epidemiological studies on melon necrotic spot. Technical Bulletin 14. Shizuoka Agricultural Experiment Station, Shizuokaken, Japan.

Garcia-Castillo, S., Sanchez-Pina, MA. \& Pallas, V. (2003) Spatio-temporal analysis of the RNAs, coat and movement (p7) proteins of Carnation mottle virus in Chenopodium quinoa 
plants. J Gen Virol 84, 745-9.

Gosalvez, B., Navarro, J.A., Lorca, A., Botella, F., Sanchez-Pina, M.A. \& Pallas, V. (2003). Detection of Melon necrotic spot virus in water samples and melon plants by molecular methods. J Virol Methods 113, 87-93.

Hacker, D.L., Petty, I.T., Wei, N. \& Morris, T.J. (1992). Turnip crinkle virus genes required for RNA replication and virus movement. Virology 186, 1-8.

Hearne, P.Q., Knorr, D.A, Hillman, B.I. \& Morris, T.J. (1990). The complete genome structure and synthesis of infectious RNA from clones of Tomato bushy stunt virus. Virology 177, 141-151.

Herranz, M.C., Sanchez-Navarro, J.A., Sauri, A., Mingarro, I., \& Pallas, V. (2005). Mutational analysis of the RNA-binding domain of the Prunus necrotic ringspot virus (PNRSV) movement protein reveals its requirement for cell-to-cell movement. Virology 339, 31-41.

Hibi, T. \& Furuki, I. (1985). Melon Necrotic Spot Virus. In: CMI: AAB Descriptions of Plants Viruses $\mathrm{N}^{\circ} 302$.

Huang, M., Koh, D.C., Weng, L.J., Chang, M.L., Yap, Y.K., Zhang, L. \& Wong, S.M. (2000). Complete nucleotide sequence and genome organization of Hibiscus chlorotic ringspot virus, a new member of the genus Carmovirus: evidence for the presence and expression of two novel open reading frames. J Virol 74, 3149-3155.

Hull, R. (2002). Virus movement through the plant and effects on plant metabolism. In Matthews' plant virology, 4th edn, pp 373-436. Edited by Academic Press, San Diego.

Kakani, K., Sgro, J.Y. \& Rochon, D. (2001). Identification of specific Cucumber necrosis virus coat protein amino acids affecting fungus transmission and zoospore attachment. $\mathrm{J}$ Virol 75, 5576-5583

Kasschau, K.D. \& Carrington, J.C. (1998). A counterdefensive strategy of plant viruses: suppression of posttranscriptional gene silencing. Cell 95, 461-470.

Knoester M., van Loon LC., van den Heuvel J., Hennig J., Bol JF. \& Linthorst HJM. (1998).Ethylene-insensitive tobacco lacks nonhost resistance against soil-borne fungi. Proc Natl Acad Sci U S A. 95, 1933-1937.

Kubo, C., Nakazono-Nagaoka, E., Hagiwara, K., Kajihara, H., Takeuchi, S., Matsuo, K., Ichiki, T. U. \& Omura, T. (2005). New severe strains of Melon necrotic spot virus: symptomatology and sequencing. Plant Pathol 54, 615-620.

Lange, L. \& Insunza, V. (1977). Root inhabiting Olpidium species: the O. radicale complex. British Mycol Soc 69, 377-384.

Li, W.Z., Qu, F. \& Morris, T.J. (1998). Cell-to-cell movement of Turnip crinkle virus is controlled by two small open reading frames that function in trans. Virology 244, 405-416.

Lough, T.J., Emerson, S.J., Lucas, W.J. \& Forster, R.L. (2001). Trans-complementation of long-distance movement of White clover mosaic virus triple gene block (TGB) mutants: phloem-associated movement of TGBp1. Virology 288, 18-28.

Lu, R., Folimonov, A., Shintaku, M., Li, W.X., Falk, B.W., Dawson, W.O. \& Ding, S.W. 
(2004). Three distinct suppressors of RNA silencing encoded by a 20-kb viral RNA genome. Proc Natl Acad Sci U.S.A 101, 15742-15747.

Mas, P. \& Pallas, V. (1995). Non-isotopic tissue printing hybridization: a new technique to study long distance plant virus movement. $J$ Virol Methods 52, 317-326.

Marcos, J. F., Vilar, M., Pérez-Payá, E. \& Pallás, V. (1999). In vivo detection, RNA-binding properties and characterization of the RNA-binding domain of the p7 putative movement protein from Carnation mottle carmovirus (CarMV). Virology 255, 354-365.

McLean, M.A., Campbell, R.N., Hamilton, R.I. \& Rochon, D.M. (1994). Involvement of the Cucumber necrosis virus coat protein in the specificity of fungus transmission by Olpidium bornovanus. Virology 204, 840-842.

Meng C, Chen J, Peng \& JWong SM. (2006). Host-induced avirulence of hibiscus chlorotic ringspot virus mutants correlates with reduced gene-silencing suppression activity. J Gen Virol. 87, 451-459.

Morales, M., Orjeda, G., Nieto, C., Leeuwen, H.V., Monfort, A., Charpentier, M., Caboche, M., Arus, P., Puigdomenech, P., Aranda, M.A., Dogimont, C., Bendahmane, A., \& Garcia-Mas, J. (2005). A physical map covering the nsv locus that confers resistance to Melon necrotic spot virus in melon (Cucumis melo L.). Theor Appl Genet 29, 1-9.

Navarro, J.A., Botella, F., Maruhenda, A., Sastre, P., Sánchez-Pina, M.A. \& Pallas, V. (2004). Comparative infection progress analysis of Lettuce big-vein virus and Mirafiori lettuce virus in lettuce crops by developed molecular diagnosis techniques. Phytopathology 94, 470-477.

Ohshima, K., Ando, T., Motomura, N., Matsuo, K. \& Sako N. (2000). Comparative study on genomes of two Japanese Melon necrotic spot virus isolates. Acta Virol 44, 309-314.

Pallás, V., Sánchez-Navarro, J. A., Más, P., Cañizares, M. C., Aparicio, F. \& Marcos, J. F. (1998). Molecular diagnostic techniques and their potential role in stone fruit certification schemes. Options Méditerr 19, 191-208.

Panavas, T., Hawkins, C.M., Panaviene, Z. \& Nagy, P.D. (2005). The role of the p33:p33/p92 interaction domain in RNA replication and intracellular localization of p33 and p92 proteins of Cucumber necrosis tombusvirus. Virology 338, 81-95.

Panaviené, Z., Baker, J.M. \& Nagy, P.D. (2003). The overlapping RNA-binding domains of p33 and p92 replicase proteins are essential for tombusvirus replication. Virology 308, 191-205.

Qu, F. \& Morris, T.J. (2005). Suppressors of RNA silencing encoded by plant viruses and their role in viral infections. FEBS Lett 579, 5958-5964.

Qu, F., Ren, T. \& Morris, T.J. (2003). The coat protein of Turnip crinkle virus suppresses posttranscriptional gene silencing at an early initiation step. J Virol 77, 511-522.

Rajendran, K.S. \& Nagy P.D. (2003). Characterization of the RNA-binding domains in the replicase proteins of Tomato bushy stunt virus. J Virol 77, 9244-9258.

Rajendran, K.S. \& Nagy P.D. (2004). Interaction between the replicase proteins of Tomato bushy stunt virus in vitro and in vivo. Virology 326, 250-261. 
Rajendran, K.S., Pogany, J. \& Nagy, P.D. (2002). Comparison of Turnip crinkle virus RNAdependent RNA polymerase preparations expressed in Escherichia coli or derived from infected plants. J Virol 76, 1707-1717.

Riviere, C.J., Pot, J., Tremaine, J.H. \& Rochon, D.M. (1989). Coat protein of Melon necrotic spot carmovirus is more similar to those of tombusviruses than those of carmoviruses. $J$ Gen Virol 70, 3033-3042.

Riviere, C.J. \& Rochon, D.M. (1990). Nucleotide sequence and genomic organization of Melon Necrotic Spot Virus. J Gen Virol 71, 1887-1896.

Robbins, M.A., Reade, R.D. \& Rochon, D.M. (1997). A Cucumber necrosis virus variant deficient in fungal transmissibility contains an altered coat protein shell domain. Virology 234 , 138-146.

Rochon, D.M. \& Tremaine, J.H. (1989). Complete nucleotide sequence of the Cucumber necrosis virus genome. Virology 169, 251-259.

Roth, B.M., Pruss, G.J. \& Vance, V.B. (2004). Plant viral suppressors of RNA silencing. Virus Res 102, 97-108.

Ruiz, M.T., Voinnet, O. \& Baulcombe, D.C. (1998). Initiation and maintenance of virus-induced gene silencing. Plant Cell 10, 937-946.

Ryabov, E.V., van Wezel, R., Walsh, J. \& Hong, Y. (2004). Cell-to-Cell, but not long-distance, spread of RNA silencing that is induced in individual epidermal cells. $J$ Virol 78, 3149-3154.

Scholthof, H.B. (2005). Plant virus transport: motions of functional equivalence. Trends Plant Sci 10, 376-382.

Thomas, C.L., Leh, V., Lederer, C. \& Maule, A.J. (2003). Turnip crinkle virus coat protein mediates suppression of RNA silencing in Nicotiana benthamiana. Virology 306, 33-41.

Verchot-Lubicz J. (2005). A new cell-to-cell transport model for Potexviruses. Mol Plant Microbe Interact 18, 283-290.

Vilar, M., Esteve, V., Pallas, V., Marcos, J. F. \& Perez-Paya, E. (2001). Structural properties of Carnation mottle virus p7 movement protein and its RNA-binding domain. $\mathrm{J}$ Biol Chem 276, 18122-18129.

Vilar, M., Sauri, A., Monne, M., Marcos, J. F., von Heijne, G, Perez-Paya, E. \& Mingarro, I. (2002). Insertion and topology of a plant viral movement protein in the endoplasmic reticulum membrane. J Biol Chem 277, 23447-23452.

Voinnet, O., Lederer, C. \& Baulcombe D.C. (2000). A viral movement protein prevents spread of the gene silencing signal in Nicotiana benthamiana. Cell 103, 157-167.

White, K.A., Skuzeski, J.M., Li, W., Wei, N. \& Morris, T.J. (1995). Immunodetection, expression strategy and complementation of Turnip crinkle virus p28 and p88 replication components. Virology 211, 525-534. 


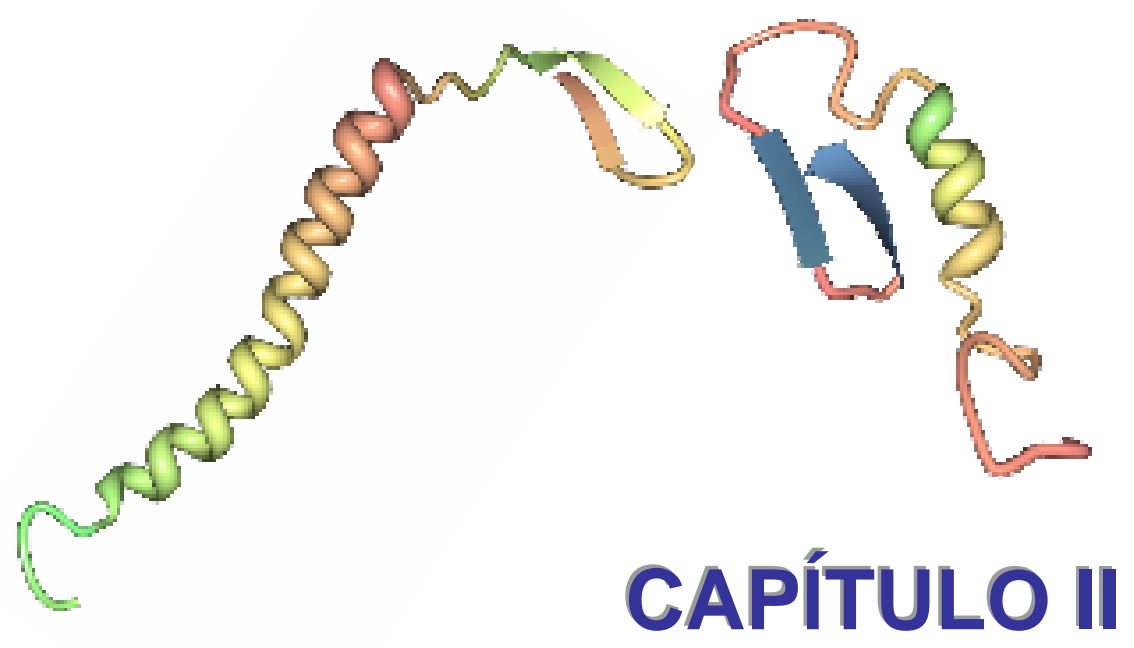




\title{
RNA-binding properties and membrane insertion of Melon necrotic spot virus (MNSV) double gene block movement
}

\section{proteins}

\author{
J. A. Navarro ${ }^{1}$, A. Genovés ${ }^{1}$, J. Climent ${ }^{1}$, A. Saurí ${ }^{2}$, L. Martínez-Gil ${ }^{2}$, I. Mingarro ${ }^{2}$ and V. \\ Pallás ${ }^{1}$ \\ 1 Instituto de Biología Molecular y Celular de Plantas, Universidad Politécnica de Valencia- \\ CSIC, Avenida de los Naranjos s/n, 46022 Valencia, Spain. \\ ${ }^{2}$ Departament de Bioquímica i Biologia Molecular, Universitat de València. 46100 Burjassot, \\ València, Spain.
}

Virology 356, 57-67.

\begin{abstract}
Advances in structural and biochemical properties of carmovirus movement proteins (MPs) have only been obtained in $\mathrm{p} 7$ and $\mathrm{p} 9$ from Carnation mottle virus (CarMV). Alignment of carmovirus MPs revealed a low conservation of amino acid identity but interestingly, similarity was elevated in regions associated with the functional secondary structure elements reported for CarMV which were conserved in all studied proteins. Nevertheless, some differential features in relation with CarMV MPs were identified in those from Melon necrotic virus (MNSV) (p7A and p7B). p7A was a soluble non-sequence specific RNA-binding protein, but unlike CarMV p7, its central region alone could not account for the RNA-binding properties of the entire protein. In fact, a 22-amino acid synthetic peptide whose sequence corresponds to this central region rendered an apparent dissociation constant $\left(K_{d}\right)$ significantly higher than that of

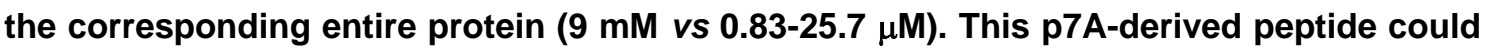
be induced to fold into an alpha-helical structure as demonstrated for other carmovirus p7-like proteins. Additionally, in vitro fractionation of p7B transcription/translation mixtures in the presence of ER-derived microsomal membranes strongly suggested that p7B is an integral membrane protein. Both characteristics of these two small MPs forming the double gene block (DGB) of MNSV are discussed in the context of the intraand inter- cellular movement of carmovirus.
\end{abstract}




\section{INTRODUCTION}

Cell-to-cell movement of plant viruses requires specific viral factors (movement proteins, MP) that direct virus transport from the primary infection point to neighbouring cells by interacting with either entire viral particles (Pouwels et al., 2004) or nucleoprotein intermediates, including active replication complexes (Kawakami et al., 2004). These viral or subviral particles are commonly targeted by the machinery of the intracellular transport of macromolecules to the cell periphery where plant viruses overcome the rigid cell wall barrier by moving through modified intercellular channels (plasmodesmata), most likely by means of an internal membranous translocation system. Consequently, MPs have inevitably been found to associate with cytoskeletal elements or endoplasmic reticulum network as well as host factors in order to assist the movement process (Heinlein and Epel, 2004; Nelson and Citovsky, 2005, Lucas, 2006). Moreover, they are forced to adjust plasmodesmata dimensions to that of the viral mobile element by increasing their size exclusion limit (Waigmann et al., 2004). Alternatively, they can cause a drastic rearrangement of the original structure that is occasionally replaced by specialized MP-tubules (Kasteel et al., 1997). Given existing data, it is evident that MPs play a central role in the spread of infection by accomplishing several functions: 1) viral genome binding (Citovsky et al., 1990; Marcos et al, 1999; Herranz and Pallas, 2004); 2) association with the intracellular transport pathway and related host factors (Lucas, 2006); 3) interaction with additional MPs or with different viral factors such as coat protein (Sanchez-Navarro et al, 2005 Verchot-Lubicz, 2005); 4) plasmodesmata gating (Wolf et al., 1989), and 5) influencing RNA silencing suppression (Bayne et al, 2005; Genoves et al., 2006). It has been reported that an individual MP may mediate most of the above mentioned activities. Otherwise, a distribution of these functions among multiple viral proteins is also possible. In this sense, five different virus-specific systems for cell-to-cell movement have been described: 1) the extensively characterized " $30 \mathrm{~K}$ superfamily" present in a large number of plant viruses representing a unique MP that shows structural similarities to the $30 \mathrm{kDa}$ MP of Tobacco mosaic virus, TMV (Melcher, 2000); 2) the tymovirus MP (Bozarth et al., 1992); 3) the two small MPs encoded by carmo-like viruses (Li et al., 1998; Vilar et al, 2001; Genoves et al., 2006) referred to as the double gene block proteins (DGBp; Hull, 2002) and the two MPs encoded by some geminiviruses (nuclear shuttle protein, NSP and movement protein, MP) (Noueiry et al., 1994; Sanderfoot and Lazarowitz, 1995); 4) the triple gene block of proteins from potexviruses (Morozov and Solovyev, 2003; Verchot-Lubicz, 2005); and 5), filamentous closteroviruses which require up to five proteins for cell-to-cell movement $(\mathrm{CP}$, minor $\mathrm{CP}$, and three MPs, namely the 6-kDa protein, the Hsp70 homolog, and the 64-kDa protein) (Prokhnevsky et al., 2002; Peremyslov et al., 2004).

Coordination between two small proteins (smaller than $10 \mathrm{kDa}$ ) encoded in the central region of the non-segmented plus stranded RNA genome of carmoviruses allows for the 
movement of both Turnip crinkle virus (TCV) as well as Melon necrotic spot virus (MNSV) genomes among adjacent cells (Hacker et al., 1992; Li et al., 1998; Cohen et al., 2000; Genoves et al., 2006). However, structural and molecular properties involving this simple movement apparatus have only been studied for the homologous MP of Carnation mottle virus (CarMV). CarMV p7 presents three different putative domains. However, only the basic central region, which adopts an $\alpha$-helical conformation in the presence of secondary structure inducers, is responsible for the RNA binding properties (Marcos et al, 1999; Vilar et al, 2001 and 2005). On the other hand, CarMV p9 contains two transmembrane domains (TM1 and TM2) (Vilar et al., 2002) that are in vitro targeted and inserted into ER-derived microsomes by means of a cotranslational/signal recognition particle (SRP)-dependent and translocon-assisted process (Sauri et al., 2005). Based on these data, a topological model has been proposed in which CarMV p9 is anchored to the membrane with its $\mathrm{N}$ - and C-terminal regions oriented to the cytoplasmic face and with its C-terminus interacting with the soluble, RNA-bound p7 partner (Vilar et al., 2002). However, data involving both p7 and p9 proteins in CarMV cell-to-cell movement in vivo are lacking.

Here we provide a structural study of homolog DGB proteins from all sequenced carmoviruses and demonstrate the in vitro RNA-binding capacity and membrane insertion ability of MNSV p7A and p7B, respectively. Characterized properties of both $p 7 A$ and $p 7 B$ demonstrate adaptation to their assigned role in MNSV cell-to-cell movement in vivo (Genoves et al., 2006), which represents a step forward towards definition of reliable molecular models for DGBp-mediated cell-to-cell movement of plant viruses.

\section{MATERIALS AND METHODS}

Expression in bacteria, purification and analysis of MNSV p7A and the deletion mutant forms.

MNSV p7A and p7B genes, and the deletion mutant forms p7A $\Delta_{1-22}$ and $p 7 A \Delta_{45-65}$, lacking the amino acid residues located between positions 1-22 ( $\mathrm{N}$-terminal region) and 45-65 (Cterminal region) respectively, were amplified from plasmid pMNSV-Al which contains the genomic sequence of the Spanish isolate MNSV-Al (DQ339157) (Gosalvez et al., 2004; Genoves et al., 2006). The PCR products were fused in frame after the coding sequence of maltose binding protein (MBP) into pMal-c2x expression vector (New England Biolabs Inc., MA, USA) to generate the recombinant constructs pMal-7A, pMal-7A $\triangle_{1-22}$ and pMal-7A $\triangle_{45-65}$. Moreover, the central region of p7A encoding residues 23-44 was deleted by reverse PCR of plasmid pMal-7A with phosphorylated oligonucleotides VP 461 and 462 (Table 1). The amplified product was self-ligated to generate plasmid pMal-7A $\Delta_{23-44}$. Alternatively, MNSV p7A gene was cloned into pETDuet-1 (Novagen) by deleting the second T7 promoter and fusing the P7A ORF 
after a sequence coding for a six histidine tag to generate pET-p7A construct. PCRs were carried out by using Vent DNA polymerase (New England Biolabs Inc., MA, USA) and indicated primer pairs (Table 1). All pMal-p7A constructions as well as pMal-c2x vector were introduced into the E. coli strain $\mathrm{DH} 5 \alpha$ by electroporation (GenePulser Xcell ${ }^{\mathrm{TM}}$ electroporator system, BioRad). E. coli strain BL21 was used in the case of pET-p7A. Next, all recombinant p7A proteins (His-tagged p7A, MBP-p7A, MBP-p7A $\triangle_{1-22}, M B P-p 7 A \triangle_{23-44}$ and MBP-p7A $\triangle_{45-65}$ ) as well as fusion MBP- $\beta$-galactosidase $\alpha$ fragment protein (MBP- $\beta$ gala) resulting from the pMal-c2x expression vector were purified as manufacturer protocol indicated. The purified proteins were quantified and analyzed by SDS-PAGE in $12 \%$ polyacrylamide gels after Coomassie brillant blue staining.

\section{Synthesis of the RBD-derived peptide and circular dichroism analysis.}

Synthetic peptide including the p7A amino acid sequence comprised between residues 23 to $44\left(\mathrm{p} 7 \mathrm{~A}_{23-44}\right.$, Ac-GGKQKNSMGRKIANDAISESKQ-NH $\left.{ }_{2}\right)$ was synthesized as previously described (Marcos et al, 1999 Secondary structure was monitored by circular dichroism spectroscopy (Jasco J-810 CD spectropolarimeter). CD spectra were the average of a series of ten scans taken at $0.2 \mathrm{~nm}$ intervals.

\section{Nucleic acid binding assay.}

Protein RNA-binding studies were performed by means of electrophoretic mobility shift assay (EMSA) as previously described (Herranz et al., 2004). Briefly, $5 \mathrm{ng}$ of a digoxigenin labelled plus-strand MNSV RNA (CP(+) RNA) located on the coat protein ORF (2841-3304 positions) and generated by in vitro transcription from BamHI-linearized pMNSV-CP (Gosalvez et al., 2004) by using T3 RNA polymerase, was heat denatured for $5 \mathrm{~min}$ at $85^{\circ} \mathrm{C}$ and then allowed to cool to room temperature for $15 \mathrm{~min}$. CP (+) RNA was incubated for $30 \mathrm{~min}$ at room temperature with different amounts of MBP-Bgala,MBP-p7A, MBP-p7B and His-tagged p7A recombinant proteins as well as with several concentrations of synthetic peptide $p 7 A_{23-44}$ in a 10 $\mu \mathrm{l}$ reaction mix also containing $10 \mathrm{mM}$ Tris- $\mathrm{HCl} \mathrm{pH} \mathrm{8.0,100} \mathrm{mM} \mathrm{NaCl}, 50 \%$ glycerol and 2 units of RNase inhibitor. Afterwards, samples were electrophoresed on a $1 \%$ agarose gel in $1 \mathrm{XTAE}$ buffer (40 mM Tris-acetate, $1 \mathrm{mM}$ EDTA, pH 8.0), capillary-transferred to positively-charged nylon membranes (Roche Diagnostics $\mathrm{GmbH}$ ) in the presence of $10 \mathrm{XSC}(1,5 \mathrm{M} \mathrm{NaCl}, 0,15 \mathrm{M}$ sodium citrate) and exposed to UV irradiation $(700 \times 100 \mu \mathrm{J} / \mathrm{cm} 2)$ to cross-link RNA. Riboprobe detection was conducted as previously described (Pallás et al., 1998).

Nucleic acid binding assay in the presence of competitors was performed by mixing the $\mathrm{CP}(+)$ RNA with either equal or with ten-fold mass excess of different types of nucleic acids as well as with a constant amount $(6 \mu \mathrm{g})$ of MBP-p7A recombinant protein. Competitors included: a

20nt-length single strand DNA (ssDNA) oligonucleotide (VP 51-1, TTTACCCACAGTGAAGCTTGC, viral positions 2841 to 2861); a double strand DNA (dsDNA) 
corresponding to $\mathrm{CP}(+)$ RNA sequence obtained by PCR using pMNSV-CP as template and primer pair VP 51-1 and VP 51-2 (TGGATCCGGTAGTAGGAATG, complementary sequence of coat protein positions 3285 to 3304 ); a 1238nt-length heterologous ssRNA consisting of the complete sequence of the coat protein from Lettuce big-vein associated virus (LBVaV) (Navarro et al., 2004) and finally, a dsRNA obtained by annealing of non-labelled $\mathrm{CP}(+) \mathrm{RNA}$ and its complementary RNA sequence CP(-) RNA followed by RNase A/RNase T1 treatment in the presence of 2 XSC.

Additionally, the RNA-binding activity dependence on salt was monitored by increasing the $\mathrm{NaCl}$ concentration in EMSA assay using $5 \mathrm{ng}$ of $\mathrm{CP}(+) \mathrm{RNA}$ and $6 \mu \mathrm{g}$ of MBP-p7A recombinant protein.

\section{Northwestern assays.}

Recombinant proteins MBP- $\beta$ gala, MBP-p7A, MBP-p7A $\Delta_{1-22}, M B P-p 7 A \Delta_{23-44}$ and MBP$\mathrm{p} 7 \mathrm{~A} \triangle_{45-65}$ were electrophoresed through $12 \%$ SDS-polyacrylamide gels and electroblotted to nitrocellulose membranes (Bio-Rad) in the presence of transfer buffer (25 mM Tris, $192 \mathrm{mM}$ glycine and $20 \%$ methanol). Northwestern-blot assays were performed as described previously (Pallás et al., 1999). The membrane-attached proteins were renatured by four-fold shaking incubation for $30 \mathrm{~min}$ a room temperature in $\mathrm{RN}$ buffer $(10 \mathrm{mM}$ Tris- $\mathrm{HCl}$ pH7.5, $1 \mathrm{mM}$ EDTA, $100 \mathrm{mM} \mathrm{NaCl}, 0.05 \%$ Triton X-100, 1X Denhardt's reagent). Digoxigenin-labelled CP(+) RNA was then added to RN buffer and incubation was continued over night. The membrane was washed three times (15 min each) in the same RN buffer lacking Triton X-100 and Denhardt's reagent. Finally, bound RNA was detected as described (Pallás et al., 1998) but Tween 20 was omitted from washing solutions and NBT-BCIP colorimetric substrate was used.

\section{In vitro transcription and translation of p7B in reticulocyte lysate.}

Plasmid pGEM-p7B was created by subcloning p7B sequence into $\mathrm{Ncol} / \mathrm{Ndel}$ restriction sites in the pGEM-Lep vector (Nilsson and von Heijne, 1993). In vitro transcription was performed as previously reported (Vilar et al., 2002). Briefly, the reaction mixtures were incubated at $37{ }^{\circ} \mathrm{C}$ for $2 \mathrm{~h}$. The mRNAs were purified using a Qiagen RNeasy clean up kit and verified on $1 \%$ agarose gel. In vitro translation of the synthesized mRNA was done in the presence of reticulocyte lysate, $\left[{ }^{35} \mathrm{~S}\right] \mathrm{Met}$, and dog pancreas microsomes as described previously (Nilsson and von Heijne, 1993; Vilar et al., 2002). After translation, the samples were analyzed by $20 \%$ SDS-PAGE.

\section{Membrane sedimentation, urea treatment, alkaline wash and triton X-114 partitioning.}

The translation reaction mixture was diluted in either 8 volumes of buffer A (35 mM Tris$\mathrm{HCl}$ at $\mathrm{pH} 7.4$ and $140 \mathrm{mM} \mathrm{NaCl}$ ) for the untreated samples, 4 volumes of buffer $A$ containing 8 $\mathrm{M}$ urea for the urea treated samples, or 4 volumes of buffer $A$ containing $100 \mathrm{mM} \mathrm{Na} \mathrm{CO}_{3}(\mathrm{pH}$ 11.5) for the alkaline extraction, as previously described (Garcia-Saez et al., 2004). The 
samples were incubated on ice for $30 \mathrm{~min}$, and then clarified by centrifugation at $10.000 \mathrm{~g}$ and 4 ${ }^{\circ} \mathrm{C}$ for $10 \mathrm{~min}$. Subsequently membranes were collected by layering the supernatant onto a 50 $\mu \mathrm{l}$ sucrose cushion and centrifugation at $100.000 \mathrm{~g}$ for $20 \mathrm{~min}$ at $4{ }^{\circ} \mathrm{C}$ in a Beckman tabletop ultracentrifuge with a TLA-45 rotor. Finally, pellets and supernatants were analyzed by $20 \%$ SDS-PAGE.

The Triton X-114 partitioning experiments were performed according to (Schaad et al., 1997). A total of $10 \mu \mathrm{L}$ of hydrated Triton X-114 were added to $55 \mu \mathrm{L}$ of the translation reactions containing microsomes, and the mixtures were incubated for $30 \mathrm{~min}$ on ice. The incubated Triton X-114 samples were equilibrated at $37{ }^{\circ} \mathrm{C}$ for $10 \mathrm{~min}$ to allow for the development of aqueous and organic phases (Bordier, 1981). These phases were then separated by centrifugation at $10.000 \mathrm{~g}$ at room temperature. Subsequently, the lower, detergent-rich fraction was washed twice by adding 10 volumes of fresh detergent-free buffer, followed by vortexing, incubation on ice for $30 \mathrm{~min}$, and phase separation as before. The proteins present in the aqueous and detergent-rich fractions were finally precipitated in acetone and analyzed by $20 \%$ SDS-PAGE.

\section{RESULTS}

\section{Sequence alignment and structural properties of homologous proteins from the carmovirus double gene block movement proteins (DGBp).}

Secondary structure prediction by computer-assisted methods and alignment of amino acid sequences were carried out with homologous DGBp from eleven carmoviruses as well as from the related Pelargonium line pattern virus (PLPV, Castano and Hernandez, 2005) as a reevaluation of the studies previously performed (Marcos et al., 1999; Cañizares et al, 2001; Vilar et al, 2001, 2002). For the 5' distal protein (referred here as DBGp1), the accuracy of prediction approaches were confirmed by a reasonable correlation between the consensus secondary structure of $\mathrm{p} 7 \mathrm{CarMV}$ obtained from data of six different computational prediction methods (PHDpsi, PROFsec, SSPro 2.01, Predator, YASPIN, JNet and PSIPred) by means of SYMPRED server (http://ibivu.cs.vu.nl/programs/sympredwww/) and that deduced experimentally by means of circular dichroism spectroscopy analyses (Vilar et al, 2001, 2002, 2005). Three different structured domains were assumed: an unordered $\mathrm{N}$-terminus, an inducible $\alpha$-helical central region and a $\mathrm{C}$-terminus with potential $\beta$-sheet folding. The presence of these secondary structure elements mapping in the homologous positions were predicted in all studied proteins (Figure 1a). Moreover, alignment of amino acid sequences computed by means of Clustal $X(1.8)$ interface (Thompson et al., 1997) revealed low sequence identity among all proteins at the $\mathrm{N}$-terminus. However, the central and $\mathrm{Ct}$-domains exhibited a moderate and high degree of similarity respectively, concordant with the prediction of secondary 
structure elements. These data suggested a conservation of amino acid properties as well as primary sequence mainly when the protein structure was affected. The a-helical structure located at the central region was variable depending on the virus, but always included a 3' distal a-helix similar to that characterized in the p7 CarMV segment ${ }^{29}$ AKDAIRK $^{35}$ (Vilar et al. 2001, 2005). This motif was also preceded by several conserved basic residues which confer a surrounding positive charge density distribution (Figure 1a). It has been demonstrated that this domain is responsible for the RNA binding properties of intact CarMV p7 by means of a RNAprotein adaptative interaction process modulated by the above mentioned secondary structure element (Marcos et al., 1999; Vilar et al, 2001 and 2005). Interestingly, most of the acidic residues are located at the $\mathrm{N}$-terminus of the protein, resulting in a negative overall charge allocation, except for MNSV, PSNV, CPMoV, CCFV and PLPV, where positively-charged residues were found at the $\mathrm{N}$-terminus and central region (Figure 1a). Finally, well-defined $\mathrm{Ct} \beta$ sheet folding was predicted in all cases.

a

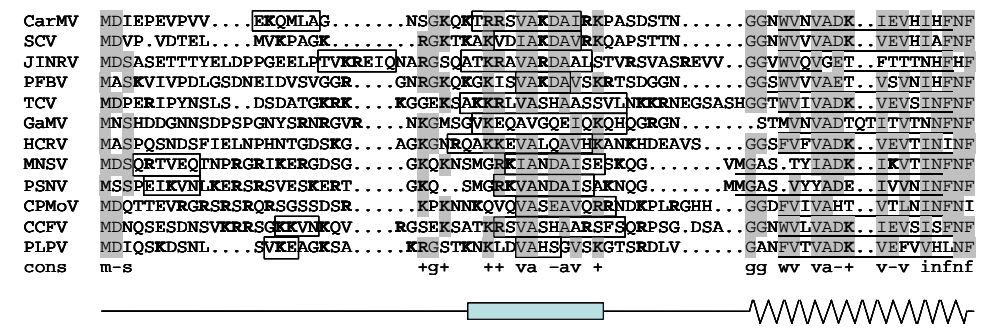

b

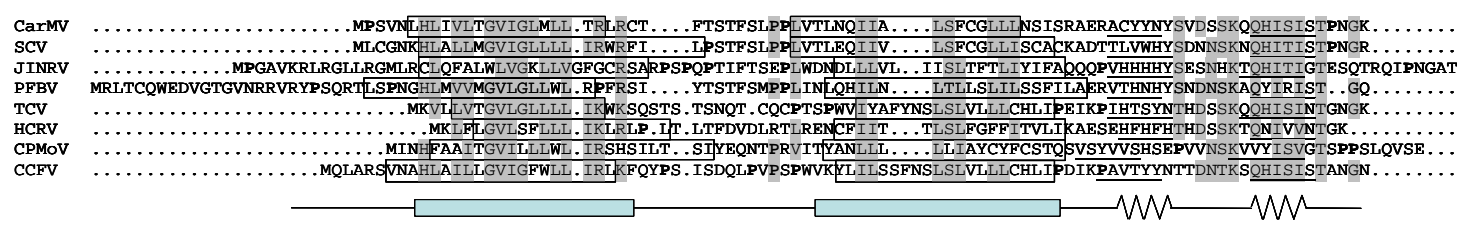

MNSV MACCRC.DSSPGDYSGALLILF.ISFVFFYITSLSPQGNTYVHHFDSSSVKTOYVGISTNGDG PSNV MACC... HDAPRDTLVAPFLAII.ICILLILISFLGRQER SY. HHIDNSSIKTQYVGISTNGK. $\begin{array}{ll}\text { GaMV } & \text { MKYCRCSDTAPTDHITLLFVIF. ILSGLILSLCTNITSNNYENHTTEN. KTQWITIG..GQQ } \\ \text { PLPV } & \ldots \text { MC.....GPSQFLISCHSHTRYILIYLSALCCASSLVQFLARPRVIVIVTFQLAPVINSSQ }\end{array}$

Figure1. (a) Amino acid alignment of the sequences from eleven Carmovirus and related Pelargonium line pattern virus (PLPV) DGBp1, CarMV-like (b, up) and MNSV-like (b, down) DGBp2. Consensus residues predicted to be involved in $\alpha$ helix or transmembrane fragments are boxed in (a) and (b), respectively, whereas $\beta$-sheet structured domains are underlined. Amino acid similitude is indicated by grey boxes and basic (K or R) or proline $(P)$ residues are in bold in (a) and (b), respectively. Symbols + and - in consensus sequence represent basic (K or R) and acid residues (D or E), respectively. A diagrammatic representation of deduced secondary structure of DGBps is displayed below each alignment. Boxes represent $\alpha$-helix or transmembrane fragments in (a) and (b), respectively and broken lines correspond to $\beta$-sheets structures. CarMV, Carnation mottle virus ( $\underline{\mathbf{X 0 2 9 8 6}})$; SCV, Saguaro cactus virus (U72332); JINRV, Japanese iris necrotic ring virus (D86123); PFBV, Pelargonium flower break virus (AJ514833); TCV, Turnip

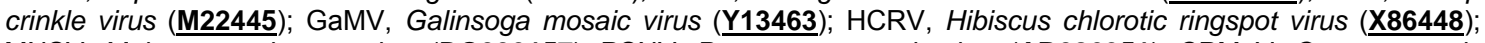
MNSV, Melon necrotic spot virus (DQ339157); PSNV, Pea stem necrosis virus (AB086951); CPMoV, Cowpea mottle

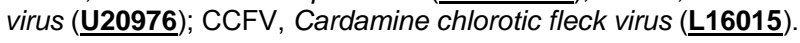


The amino acid sequence from 3' distal homolog proteins (DGBp2) were analyzed for possible transmembrane (TM) segments with the aid of TMHMM (Krogh et al., 2001), DAS (Cserzö et al., 1997), HMMTOP (Tusnady and Simon, 1998) and TopPredll (Claros and von Heijne, 1994). Consensus domains are presented in Figure 1b. Homologs DGBps2 show a high percentage of hydrophobic amino acids distributed along either one or two predicted TM $\alpha$ helices $(\mathrm{TMH})$, arranging the proteins into two different groups that we refer to as CarMV-like (Figure 1b, upper group) and MNSV-like (Figure 1b, lower group). A conserved $\beta$-sheet structure was predicted at the C-terminus of both groups, most likely involved in the interaction with the similar motif at the C-terminus of DGBp1 (Vilar et al, 2001). As previously observed with DGBp1, homologs of DGBp2 show an overall low sequence identity, although regions with moderate similarity are associated with the presence of TMH. Interestingly, both $\mathrm{TMH}$ from CarMV-like DGBp2 are separated by a polar region containing several proline residues (Figure $1 \mathrm{~b}, \mathrm{up})$. The cyclic structure of this amino acid strongly restricts the conformational space of the peptide chain in protein structures and tends to inhibit both $\alpha$-helical and $\beta$-sheet structure formation. This probably forces the proteins to fold as helical hairpins. In this sense, it has been recently shown that this short loop ensures that, after translation, both $\mathrm{TMH}$ fragments from CarMV p9 leave the translocon complex in a concerted fashion to become membrane embedded (Saurí et al., 2005).

\section{RNA-binding properties of MNSV p7A.}

A relationship between DGBps and carmovirus cell-to-cell movement can be inferred by sequence similarity with DGBp from TCV and MNSV, the two carmoviruses where these proteins have been shown to be directly involved in in vivo cell-to-cell movement (Hacker et al., 1992; Li et al., 1998; Cohen et al., 2000; Genoves et al., 2006). However, DGBp from MNSV have some different structural features compared with well-characterized CarMV DGBp: the 5' distal protein ( $p 7 A)$ shows a different distribution of positive charge residues, and only one membrane spanning domain was predicted for DGBp2 (p7B). Therefore, to investigate whether the CarMV DGBp properties (Marcos et al., 1999; Vilar et al, 2001and 2002) are assumed by homolog MNSV proteins, studies on both in vitro p7A RNA binding properties as well as p7B membrane insertion were performed.

The putative RNA-binding properties of the p7A movement protein were studied by in vitro EMSA (Herranz and Pallas, 2004) using increasing amounts of a recombinant protein expressed in bacteria consisting of the p7A fused at the $\mathrm{N}$ terminus with maltose binding protein (MBP-p7A), and a MNSV-specific DIG-labelled ssRNA (CP(+) RNA) (Figure 2a, left). RNA mobility shifts, suggesting the presence of an RNA-protein interaction, became detectable when $400 \mathrm{ng}$ of MBP-p7A protein was added to the reaction mixture. Maximal binding occurred using $6 \mu \mathrm{g}$ of protein, as measured by disappearance of unbound RNA. Comparable concentrations of MBP-ßgala protein expressed in bacteria containing the empty pMal-c2x vector failed to bind 
$\mathrm{CP}(+) \mathrm{RNA}$, indicating that the shift observed in the EMSAs was specific for p7A (data not shown). Interestingly, the MBP-p7A:RNA complexes formed at higher protein amounts slightly increased the electrophoretical mobility of the ribonucleoprotein complex, which at lower protein amounts (between 0.4-6 $\mu \mathrm{g}$ ), migrated only slightly into the gel matrix. Similar results have been previously reported for Prunus necrotic ringspot virus MP indicating that the higher protein amounts the greater protein-protein interactions that result in a structural change of the ribonucleoprotein complex from rod-like to a globular form (Herranz and Pallas, 2004). Alternatively, a His-tagged p7A was used in in vitro EMSA. As expected from the previous experiments performed with the fusion protein MBP-p7A, RNA mobility shift was also detected although in this case, intermediate complexes were observed (Figure3).

a
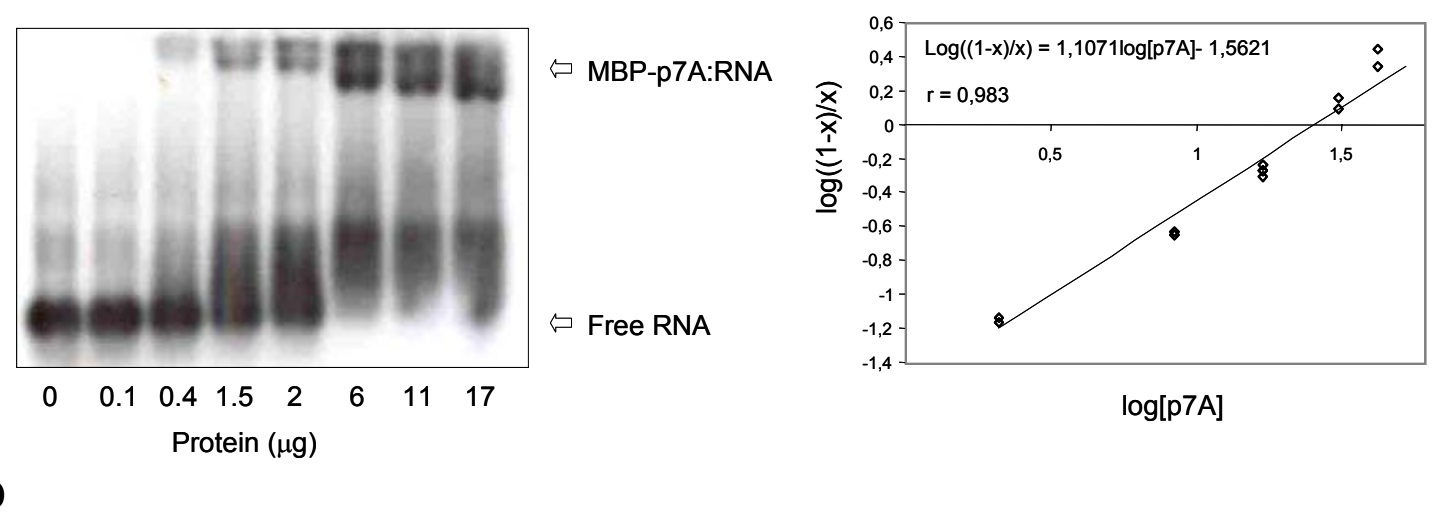

b
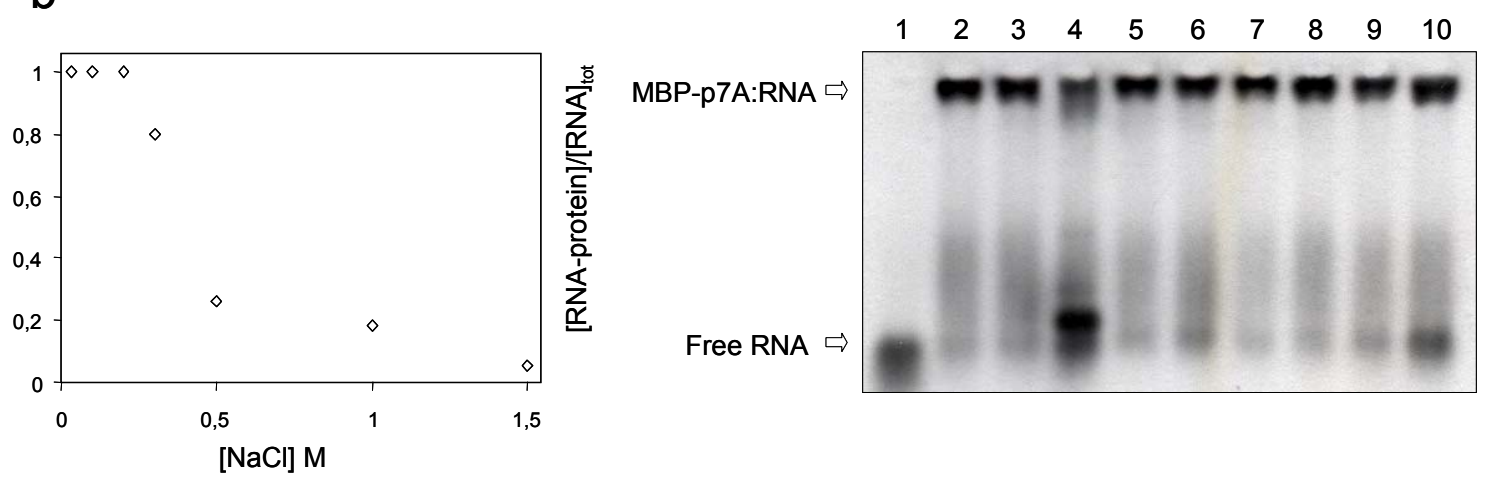

Figure 2. Determination of the in vitro RNA binding properties of the recombinant MBP-p7A. a) Analysis of MBP-p7A binding to ssRNA (CP (+) RNA) by electrophoretic mobility shift assays (EMSA) (left) and binding kinetics determined by Hill transformation of data from three independent EMSA (right). Equation of linear regression and the corresponding $r$ coefficient are indicated into the graphic representation. b) Dependence of MBP-p7A RNA-binding activity on salt concentration represented as the fraction of bound RNA against NaCl concentration (left) and ssRNA binding specificity (right) measured by EMSA in the absence (lane 2) and presence (lanes 3 to 10) of either equal (odd lanes) or ten-fold (even lanes) mass excess of different classes of competitors: heterologous ssRNA (lanes 3 and 4) and homologous dsRNA (lanes 5 and 6), ssDNA (lanes 7 and 8) and dsDNA (lanes 9 and 10). Lane 1 corresponds to electrophoretic mobility of the ssRNA probe in the absence of MBP-p7A.The position of free and protein bound RNA on EMSA are marked. 
Binding kinetics analysis was performed using a Hill transformation of data from three independent experiments using both MBP-p7A and His-tagged p7A (Figure 2a, right and Figure $3 b$, respectively). RNA-protein complex formation was measured as the disappearance of the band corresponding to unbound $\mathrm{CP}(+)$ RNA from each EMSA (Carey, 1991; Daros and Carrington, 1997). The apparent dissociation constants $\left(K_{d}\right)$ for both MBP-p7A: RNA and Histagged p7A: RNA complexes were calculated from linear regression as the p7A concentration at which half of the RNA is bound. These values $(25.7 \mu \mathrm{M}$ and $0.82 \mu \mathrm{M}$, respectively). were in the same order as those corresponding to homolog CarMV p7 (2.4 $\mu \mathrm{M})$ (Marcos et al., 1999; Vilar et al, 2001) as well as to other sequence non-specific RNA-binding proteins (Burd and Dreyfuss, 1994; Pata et al., 1995; Skuzeski and Morris, 1995; Daros and Carrington, 1997; Herranz and Pallas, 2004). Additionally, Hill plot of the data provides a mathematical calculation of the degree of cooperativity in the binding event, which is provided by the gradient of the resulting line or Hill coefficient (c). The $c$ values for MBP-p7A:RNA and His-tagged p7A binding kinetics were slightly higher than 1 ( $c=1.1$ and 1.3 , respectively). Therefore, a low degree of cooperativity could be assigned to the process ( $c=1$ is indicative of no cooperativity) suggested by the presence of intermediates complexes in the EMSA performed with the His-tagged p7A (Figure 3a) (Marcos et al, 1999). The size of MBP moiety present in the fusion protein MBP-p7A may affect p7A-p7A interactions so that decreasing the $c$ value and perhaps, avoiding also the appearance of intermediate complexes.

a

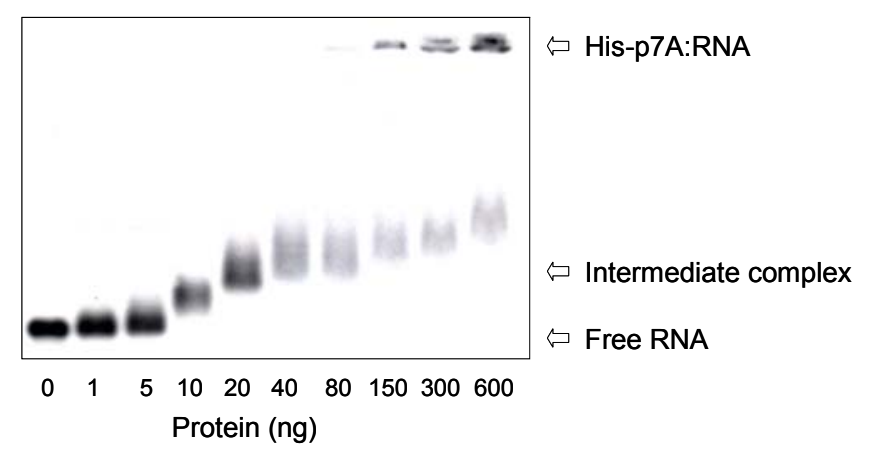

b

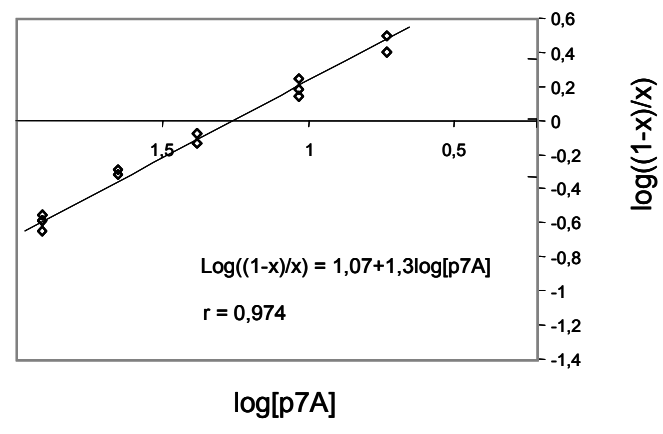

Figure 3. Determination of the in vitro RNA binding properties of the recombinant His-p7A. Analysis of His-p7A binding to ssRNA (CP (+) RNA) by electrophoretic mobility shift assays (EMSA) (a) and binding kinetics determined by Hill transformation of data from three independent EMSA (b). The position of free and protein bound RNA on EMSA are marked. Equation of linear regression and the corresponding $r$ coefficient are indicated into the graphic representation. 
To challenge the forces that govern the MBP-p7A:RNA interaction, complex resistance was evaluated by increasing $\mathrm{NaCl}$ concentration of the incubation mixtures in the presence of a protein concentration $(6 \mu \mathrm{g})$ that was sufficient to bind all CP (+) RNA molecules. The appearance of free RNA was quantified to evaluate complex dissociation and a $50 \%$ reduction of binding was observed at $\mathrm{NaCl}$ concentration of $435 \mathrm{mM}$ (IC50) (Figure 2b, left). This remarkable salt tolerance was similar to that observed with homolog TCV p8 (Wobbe et al., 1998) suggesting that interactions other than electrostatics between the RNA and the MP are involved in binding (Herranz and Pallas, 2004). These results are in contrast with those obtained in similar assays but using a recombinant protein consisting of the MNSV p7B fused the $\mathrm{N}$ terminus with MBP (MBP-p7B) (Figure 4). Free RNA consistently disappeared only at a $\mathrm{NaCl}$ concentration of $50 \mathrm{mM}$. Putative interaction was unstable at any other salt concentration most likely indicating an artefactual RNA binding.

Finally, competitive binding assays were performed to examine the selectivity of p7A to bind different nucleic acids (Figure $2 \mathrm{~b}$, right). Reaction mixtures containing the DiG-labelled $\mathrm{CP}(+)$ ssRNA were assembled in the presence of a 10-fold mass excess of unlabelled competitors. The ssRNA from a heterologous origin (Lettuce big vein virus; LBVV; Navarro et al., 2004) was able to compete at 10 -fold excess (Figure $2 \mathrm{~b}$, lanes 3 and 4 ), whereas the dsDNA weakly displaced the binding only at a 10 -fold ratio (Figure $2 \mathrm{~b}$, lanes 9 and 10 ). Both dsRNA and ssDNA had no effect on the electrophoretic retardation (Figure 2b, lanes 5 to 8). These results indicated that the p7A has a preference for ssRNA binding in a sequence nonspecific manner.

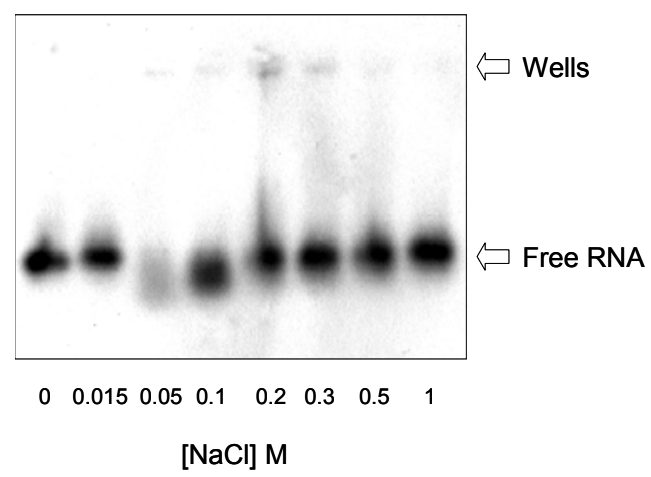

Figure 4. Mobility shift assays of $\mathrm{CP}(+) \mathrm{RNA}$ in the presence of MBP-p7B using different $\mathrm{NaCl}$ concentrations. The position of free RNA and gel wells on EMSA are marked.

\section{Characterization of the RNA-binding domain of p7A MP.}

Three deletion variants lacking each of the previously mentioned p7A structural regions (Figure 5a) were expressed as MBP fusion proteins to avoid incorrect conformation after denaturation and refolding (Citovsky et al., 1992; Vaquero et al., 1997) in Northwestern assay 
(Aparicio et al., 2003, Herranz and Pallas, 2004). Recombinant MBP-p7A $\triangle_{1-22}$ and MBP-p7A $\triangle_{45}$ 65, deficient in the $\mathrm{N}$-terminal and $\mathrm{C}$-terminal domains respectively, showed strong reduction of RNA binding activity when compared with full-length MBP-p7A (Figure 5b, compare lane 2 with 4 and 6). However, deletion of the basic $\alpha$-helical predicted domain located in the central portion of the protein (mutant MBP-p7A $\Delta_{23-44}$ ) eliminated RNA:protein interaction (Figure $5 b$, lane 5 ). No binding of the riboprobe was observed with MBP-Bgala protein (Figure $5 \mathrm{~b}$, lane 3 ). This p7A RNA binding domain (RBD) fits well with the previously described RBD from p7 CarMV (Marcos et al., 1999; Vilar et al, 2001, 2005).

a

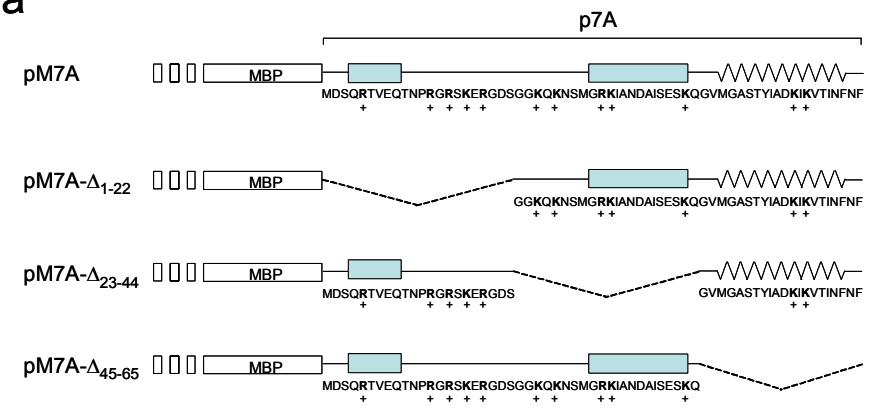

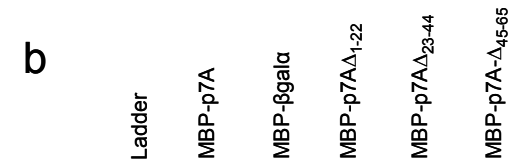

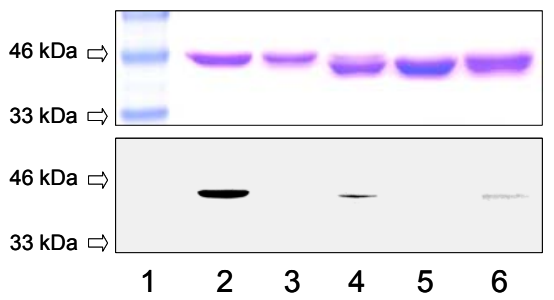

Figure 5 Characterization of the RNA binding domain (RBD) of p7B a) Diagrammatic representation of the pMal-7A and its mutant forms pMal-7A $\Delta_{1-22}$, pMal-7A $\Delta_{23-44}$ and pMal-7A $\Delta_{45-65}$. Numbers in the construct name and discontinuous lines in diagram refer to the amino acid residue position deleted from wild-type protein. Grey boxes and broken line represent $\alpha$-helix and $\beta$-sheets structures, respectively. Symbols + indicated the position of basic residues (K or R). b) SDS-PAGE analysis of the purified MBP- $\beta$ gal $\alpha$, MBP-p7A and its deleted forms in a $12 \%$ gel stained with Coomassie blue (up) and the corresponding ssRNA binding analysis by Northwestern blot assay (down). The positions of the molecular mass markers are indicated on the left.

To corroborate these results a 22-amino acid synthetic peptide covering p7A positions 23

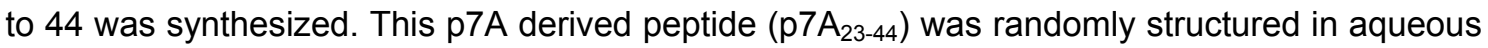
solution as monitored through far-UV circular dichroism spectroscopy. However, increasing concentrations of secondary structure inducers, such as trifluorethanol (TFE) (Figure 6a, left panel) and SDS (Figure 6a, right panel) induced p7 $\mathrm{A}_{23-44}$ to fold into an $\alpha$-helical conformation. In vitro RNA-binding properties of $\mathrm{p} 7 \mathrm{~A}_{23-44}$ peptide were demonstrated by EMSA and the kinetics of the process was evaluated by the same approach used with the MBP-p7A protein (Figure $6 \mathrm{~b}) . K_{d}$ from $\mathrm{p} \mathrm{A}_{23-44}$ peptide was higher than that observed for the MBP-p7A protein (9 $\mathrm{mM}$ vs $25.7 \mu \mathrm{M}$, respectively). 
a

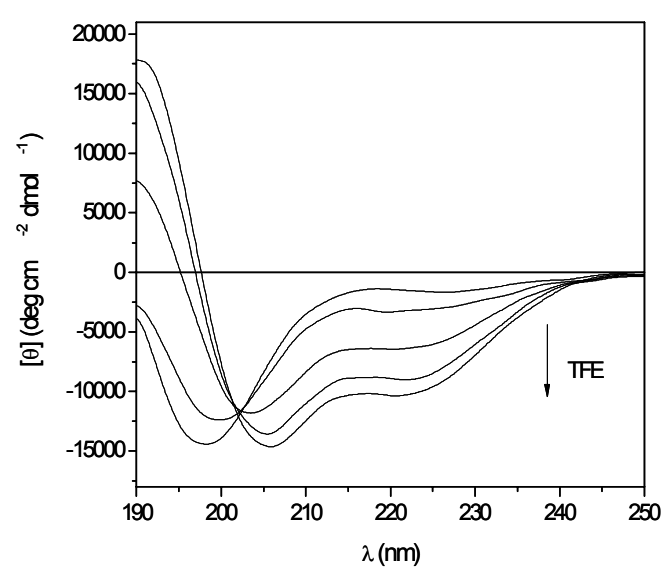

b peptide $(\mathrm{mM})$
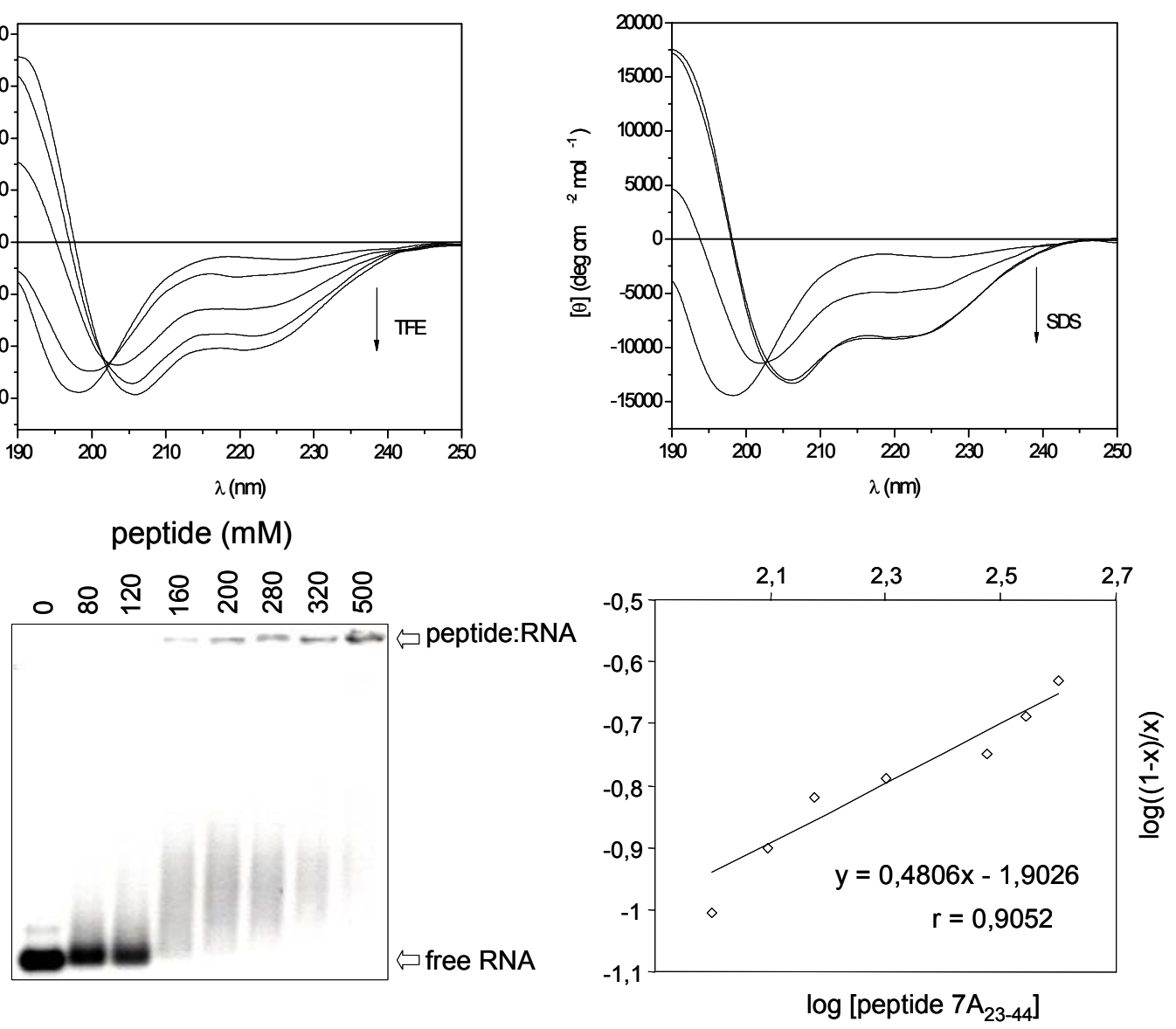

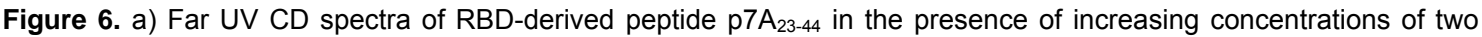
different secondary structure inductors, TFE $(20,4060$ and $70 \%$, as the arrow indicates) and SDS (1, 5 and $10 \mathrm{mM})$. Peptide concentration was $30 \mu \mathrm{M}$ in $5 \mathrm{mM}$ MOPS/NaOH buffer, pH 7.0 at $25^{\circ} \mathrm{C}$. b) RNA-binding analysis of different amount of peptide $\mathrm{p} \mathrm{A}_{23-44}$ by EMSA (left) and Hill transformation of data (right). Equation of linear regression and the corresponding $r$ coefficient are indicated.

\section{p7B is an integral membrane protein.}

Computer analysis of the $\mathrm{p7B}$ amino acid sequence predicted that $\mathrm{p} 7 \mathrm{~B}$ is a membrane protein with a single transmembrane domain, roughly spans from residue 14 to residue 32 . To test the computer predictions, in vitro p7B transcription/translation experiments were performed in the presence of ER-derived microsomal membranes. After centrifugation of the translation reaction mixture, p7B was recovered from the $100.000 \mathrm{~g}$ pellet fraction (Figure $7 \mathrm{a}$, untreated lanes) indicating that it could be either a membrane-associated (peripheral or integral) protein or a luminal protein (Figure $7 \mathrm{~b}$ ). To differentiate between these possibilities, translation reaction mixtures were either treated with $8 \mathrm{M}$ urea or washed with sodium carbonate $(\mathrm{pH} 11.5)$. Urea was expected to dislodge proteins that are weakly or peripherally associated with membranes (Figure 7b, scheme 2) (Schaad et al., 1997) whereas sodium carbonate renders microsomes into membranous sheets, thus releasing the soluble luminal proteins (Figure $7 \mathrm{~b}$, scheme 1) (Peremyslov et al., 2004). After treatments with both agents, p7B appeared to be mainly 
associated with the membranous pellet fraction (Figure 7a), suggesting a tight association with microsomal membranes. To confirm this conclusion, p7B translation reaction mixtures were also treated with Triton $\mathrm{X}-114$, a detergent that forms a separate organic phase to which the membrane lipids and hydrophobic proteins are segregated (Bordier, 1981). Because p7B was detected in the organic, but not the aqueous phase (Figure 7a), we concluded that p7B is an integral membrane protein. Further experiments will be needed to define its topology (Figure $7 \mathrm{~b}$, scheme 3).

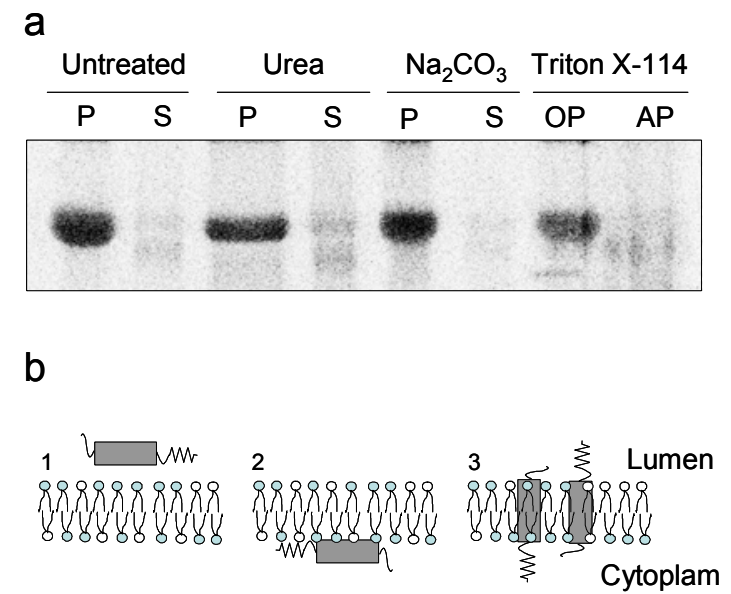

Figure 7. Location in dog pancreas microsomes of p7B protein transcribed/translated in vitro a) Segregation of $\left[{ }^{35}\right.$ S]Met labelled p7B into membranous fraction after urea treatment, alkaline wash (sodium carbonate buffer) and triton $\mathrm{X}-114$ partitioning. $\mathrm{P}$ and $\mathrm{S}$, pellet and supernatant, respectively; $\mathrm{OP}$ and $\mathrm{AP}$, organic and aqueous phases, respectively. b) Representation of the different membrane association possibilities of p7B with microsomes as luminal (1) and either peripheral (2) or integral (3) membrane-anchored protein.

\section{DISCUSSION}

Non-virion cell-to-cell movement of plant carmoviruses involves specific transport of replicated genomes by means of two small movement proteins (DGBp) and in some instances requiring coat protein (Hacker et al., 1992; Li et al., 1998; Cohen et al., 2000; Genoves et al., 2006). Although the alignment of carmovirus homolog DGB proteins revealed low identity, similarity of amino acid sequences was noted that mostly affected regions arranged as conserved secondary structure elements. These data suggest that the biological function of both proteins is dependent on the physical and chemical properties of the residues either by itself or by influencing the folding of the polypeptide backbone rather than primary structure. In vitro studies have shown that the proteins encoded by the DGB 5 '-proximal genes from both TCV and CarMV are able to bind RNA in a sequence non-specificity fashion. However, only CarMV p7 RBD has been well-characterized and localized to the basic central region of the protein (Wobbe et al., 1998; Marcos et al., 1999; Vilar et al. 2001, 2005). CarMV p7 RBD 
consists of an $\alpha$-helical inducible structure that also includes almost all basic residues of the protein. Both secondary structure and positively charged amino acids modulate RNA binding by means of an RNA:protein adaptative process (Vilar et al., 2001, 2005). Moreover, a lysine to glutamate mutation in amino acid position 25 of TCV p8 reduced RNA binding activity and virulence on Arabidopsis thaliana (Wobbe et al., 1998). The essential role of basic residues in RNA binding has been described for MPs such as TGBp1 (Morozov and Solovyev, 2003) and the 30K superfamily (Herranz et al., 2005) from other positive ssRNA virus. Despite the fact that the $\alpha$-helix is predicted at nearly the same position in all homolog DGBp1, the distribution of basic residues varied considerably and was not always concentrated in the central region as was found for MNSV p7A. Gel-shift assays revealed that p7A can bind ssRNA non-specifically in a slightly cooperative manner as expected. However, when RNA complex formation by fulllength $\mathrm{p7A}$ and three deletion mutants was tested by Northwestern assays, results revealed that although RNA binding was impaired when the central region was removed, deletion of either the $\mathrm{Nt}$ or $\mathrm{Ct}$ region also dramatically reduced binding. Unlike the negatively charged $\mathrm{Nt}$ from CarMV p7, the Nt from MNSV p7A contains a number of positively charged amino acids (five basic residues conferring an overall charge of +1 vs the +3 observed at the central domain). Therefore, the p7A Nt could also participate in RNA-binding as an extension of the basic central RBD. Finally, the lack of the $\beta$-sheet $\mathrm{Ct}$ domain in the MBP-p7A $\triangle_{45-65}$ mutant protein could hypothetically affect the cooperative binding of protein molecules prior to fixation onto a solid phase in Northwestern assays or it might influence the correct folding of the rest of the molecule; both of these possibilities could affect the RNA binding. These results are in accordance with the $K_{d}$ values from gel shift assays using the p7A $23-44$ peptide and MBP-p7A protein (9 mM vs $25.7 \mu \mathrm{M}$, respectively), which revealed that the central region alone could not account for the RNA-binding properties of the entire p7A protein unlike that observed with CarMV p7 and its RBD derived peptide ( $K_{d}$ values: 0,7 and $1,1 \mu \mathrm{M}$, respectively) (Marcos et al, 1999).

Since nucleic acid binding associated with MPs seems to be a non-sequence specific process, MPs are possibly translated in close proximity to the genome replication complex to bind viral but not host plant RNA. Therefore, the ability of a virus to move is determined by interactions among the genome-MP complex and host proteins from cellular secretory pathways and the cytoskeleton (Nelson and Citovsky, 2005; Scholthof, 2005). In the TGB system, TGBp2 and TGBp3 play this role since they have been described as integral membrane proteins that are associated with the endoplasmic reticulum (ER) (Morozov and Solovyev, 2003; VerchotLubicz, 2005). TGBp3 redirects TGBp2 and most likely TGBp1 from the ER network to the plasmodesmata (Haupt et al., 2005; Solovyev et al., 2000; Zamyatnin et al., 2004). In carmoviruses, in vitro experiments demonstrated that CarMV p9 is the responsible for the interaction with ER (Vilar et al, 2002 Sauri et al., 2005). As with hordei-like and potex-like TGBp3, two- or single-spanning transmembrane domains are predicted for CarMV-like and 
MNSV-like DGBp2, respectively. Evidence is herein provided that MNSV p7B and most likely all single-spanning transmembrane DGBp2 also insert in vitro into the ER lipid bilayer as integral proteins. Therefore, MNSV-like DGBp2 like potex-TGBp3 may be functionally sufficient to direct the intracellular movement of the carmovirus complex DGBp1:RNA. Alternatively, a dimerization process could be involved. In this sense, several cysteine residues that are located at all homolog MNSV-like but not CarMV-like DGBp2 Nt can potentially generate intermolecular covalent disulfide bonds as occurs with the 6-kDa transmembrane protein from closteroviruses (Peremyslov et al., 2004). Cysteines are conserved among all sequenced isolates of MNSV except for the residue located at position 4, which was replaced by Tyrosine in five isolates (data not shown). Interestingly, anomalous Cys-Tyr covalent bonds involving protein interactions have been described (Diaz et al., 2004).

To conclude, viral genome binding function seems to be accomplish by $\mathrm{p} 7 \mathrm{~A}$ whereas $\mathrm{p} 7 \mathrm{~B}$ could be involved in the association with the intracellular membrane system. Both functions have been described for a number of viral MPs. However, the molecular mechanism used to target the MNSV ribonucleoprotein complex to plasmodesmata and then from cell-to-cell in a coat protein-independent process and linked to the p7B silencing suppression (Genoves et al., 2006 ) is still unknown. In this scenario, unlike the $30 \mathrm{~K}$ family, TGB and other multicomponent transport systems, carmovirus movement based on DGB of MPs is energy-dependent on host proteins. Therefore, this simple system converts such virus into a suitable model of study to advance into the knowledge of mechanisms involved in plant virus cell-to-cell movement and the interactions with host factors produced during the process.

\section{ACKNOWLEDGEMENTS}

We thank V. Navarro for her technical assistance. This work was supported by Grants BIO05-7331 and GV04B-183 from the grating agency DGICYT and Generalitat Valenciana, respectively. J.A. Navarro and A. Genovés are recipients of an I3P contract and a PhD fellowship from the Consejo Superior de Investigaciones Científicas and the Spanish Ministerio de Educacion y Ciencia, respectively. 


\section{REFERENCES}

Aparicio, F., Vilar, M., Pérez-Payá, E., Pallás, V., 2003. The coat protein of Prunus necrotic ringspot virus specifically binds to and regulates the conformation of its genomic RNA. Virology 313, 213-223.

Bayne, E.H., Rakitina, D.V., Morozov, S.Y., Baulcombe, D.C., 2005. Cell-to-cell movement of Potato Potexvirus $X$ is dependent on suppression of RNA silencing. Plant J 44, 471-482.

Bozarth, C.S., Weiland, J.J., Dreher, T.W., 1992. Expression of ORF-69 of Turnip yellow mosaic virus is necessary for viral spread in plants. Virology 187, 124-130.

Bordier, C., 1981. Phase separation of integral membrane proteins in Triton X-114 solution. J Biol Chem 256, 1604-1607.

Burd, C.G., Dreyfuss, G., 1994. Conserved structures and diversity of functions of RNA-binding proteins. Science 256, 615-621.

Canizares, M.C., Marcos, J.F., Pallas, V., 2001. Molecular variability of twenty-one geographically distinct isolates of Carnation mottle virus (CarMV) and phylogenetic relationships within the Tombusviridae family. Arch Virol 146, 2039-2051.

Carey, J., 1991. Gel retardation. In Methods in Enzymology. Protein-DNA Interactions. pp. 103117. Edited by R.T. Sauer. Academic Press. San Diego, CA.

Castano A, Hernandez C., 2005. Complete nucleotide sequence and genome organization of Pelargonium line pattern virus and its relationship with the family Tombusviridae. Arch Virol 150, 949-65.

Citovsky, V., Knorr, D., Schuster, G., Zambryski, P. 1990. The p30 movement protein of Tobacco mosaic virus is a single-strand nucleic acid binding protein. Cell 60, 637-647.

Citovsky, V., Wong, M. L., Shaw, A.L., Venkataram, P.B.V., Zambryski, P., 1992. Visualisation and characterisation of Tobacco mosaic virus movement protein binding to single-stranded nucleic acids. Plant Cell 4, 397-411.

Claros, M.G., von Heijne, G., 1994 TopPred II: An improved software for membrane protein structure prediction. CABIOS 10, 685-686.

Cohen, Y., Gisel, A., Zambryski, P.C., 2000. Cell-to-cell and systemic movement of recombinant green fluorescent protein-tagged Turnip crinkle viruses. Virology 273, 258-266.

Cserzö, M., Wallin, E., Simon, I., von Heijne, G., Elofsson, A., 1997. Prediction of transmembrane $\alpha$-helices in prokaryotic membrane proteins: the Dense Alignment Surface method. Protein Engineer 10, 673-676.

Daròs, J.A., Carrington, J.C. 1997. RNA binding activity of Nla proteinase of Tobacco etch potyvirus. Virology 237, 327-336.

Diaz, A., Horjales, E., Rudino-Pinera, E., Arreola, R., Hansberg, W., 2004. Unusual Cys-Tyr covalent bond in a large catalase. J Mol Biol 342, 971-985.

Garcia-Saez, A.J., Mingarro, I., Perez-Paya, E., Salgado, J., 2004. Membrane-insertion fragments of Bcl-xL, Bax, and Bid. Biochemistry 43, 10930-10943. 
Genoves, A., Navarro, J.A., Pallas, V., 2006. Functional analysis of the five Melon necrotic spot virus genome-encoded proteins. J Gen Virol 87, 2371-2380.

Hacker, D.L., Petty, I.T., Wei, N., Morris, T.J., 1992. Turnip crinkle virus genes required for RNA replication and virus movement. Virology 186, 1-8.

Haup, S., Cowan, G.H., Ziegler, A., Roberts, A.G., Oparka, K.J., Torrance, L., 2005. Two plantviral movement proteins traffic in the endocytic recycling pathway. Plant Cell 17, 164-181.

Heinlein, M., Epel, B.L., 2004. Macromolecular transport and signaling through plasmodesmata. Int Rev Cytol 235, 93-164.

Herranz, M.C., Pallas V., 2004. RNA-binding properties and mapping of the RNA-binding domain from the movement protein of Prunus necrotic ringspot virus. J Gen Virol 85, 761768.

Herranz, M.C., Sanchez-Navarro, J.A., Sauri, A., Mingarro, I., Pallas, V., 2005. Mutational analysis of the RNA-binding domain of the Prunus necrotic ringspot virus (PNRSV) movement protein reveals its requirement for cell-to-cell movement. Virology 339, 31-41.

Hull, R., 2002. Virus movement through the plant and effects on plant metabolism. In Matthews' plant virology, 4th edn, pp 373-436. Edited by Academic Press, San Diego.

Kasteel, D.T., Wellink, J., Goldbach, R.W., van Lent, J.W. 1997. Isolation and characterization of tubular structures of Cowpea mosaic virus. J Gen Virol 78, 3167-3170.

Kawakami, S, Watanabe, Y., Beachy, R.N., 2004. Tobacco mosaic virus infection spreads cell to cell as intact replication complexes. Proc Natl Acad Sci U S A 101, 6291-6296.

Krogh, A., Larsson, B., von Heijne, G., Sonnhammer, E.L., 2001. Predicting transmembrane protein topology with a hidden Markov model: application to complete genomes. J Mol Biol 305, 567-580.

Li, W.Z., Qu, F., Morris, T.J., 1998. Cell-to-cell movement of Turnip crinkle virus is controlled by two small open reading frames that function in trans. Virology 244, 405-16.

Lin K., Simossis V.A., Taylor W.R., Heringa J. 2005. A Simple and Fast Secondary Structure Prediction Algorithm using Hidden Neural Networks. Bioinformatics. 21, 152-159.

Kawakami, S, Watanabe, Y., Beachy, R.N., 2004. Tobacco mosaic virus infection spreads cell to cell as intact replication complexes. Proc Natl Acad Sci U S A 101, 6291-6296.

Li, W.Z., Qu, F., Morris, T.J., 1998. Cell-to-cell movement of Turnip crinkle virus is controlled by two small open reading frames that function in trans. Virology 244, 405-16.

Lucas, W.J., 2006. Plant viral movement proteins: agents for cell-to-cell trafficking of viral genomes. Virology 344,169-184.

Marcos, J.F., Vilar, M., Perez-Paya, E., Pallas, V., 1999. In vivo detection, RNA-binding properties and characterization of the RNA-binding domain of the p7 putative movement protein from Carnation mottle carmovirus (CarMV). Virology 255, 354-365.

Melcher, U., 2000. The '30K' superfamily of viral movement proteins. J Gen Virol 81, 257-266.

Morozov, S.Y., Solovyev, A.G., 2003. Triple gene block: modular design of a multifunctional machine for plant virus movement. J Gen Virol 84, 1351-1366. 
Navarro, J.A., Botella, F., Maruhenda, A., Sastre, P., Sánchez-Pina, M.A., Pallas, V. 2004. Comparative infection progress analysis of Lettuce big-vein virus and Mirafiori lettuce virus in lettuce crops by developed molecular diagnosis techniques. Phytopathology 94:470-477.

Nelson, R.S., Citovsky, V., 2005. Plant viruses. Invaders of cells and pirates of cellular pathways. Plant Physiol 138, 1809-1814.

Nilsson, I., von Heijne, G., 1993. Determination of the distance between the oligosaccharyltransferase active site and the endoplasmic reticulum membrane. J Biol Chem 268, 5798-5801.

Noueiry, A.O., Lucas W.J., Gilbertson, R.L., 1994. Two proteins of a plant DNA virus coordinate nuclear and plasmodesmatal transport. Cell 76, 925-932.

Pallás, V., Más, P., Sánchez-Navarro, J.A., 1998. Detection of plant RNA viruses by nonisotopic dot-blot hybridisation. In: G. Foster and S. Taylor (Eds), Plant Virus Protocols: From Virus Isolation to Transgenic Resistance, Humana Press, Totowa, New Jersey, pp. 461-468.

Pata, J. D., Schultz, S. C., Kirkegaard, K., 1995. Functional oligomerization of poliovirus RNAdependent RNA polymerase. RNA 1, 466-477.

Peremyslov, V.V., Pan, Y.W., Dolja V.V., 2004. Movement protein of a closterovirus is a type III integral transmembrane protein localized to the endoplasmic reticulum. J Virol $78,3704-$ 3709 .

Pouwels, J., van der Velden, T., Willemse, J., Borst, J.W., van Lent, J., Bisseling, T., Wellink, J., 2004. Studies on the origin and structure of tubules made by the movement protein of Cowpea mosaic virus. J Gen Virol. 85, 3787-3796.

Prokhnevsky, A.I., Peremyslov, V.V., Napuli, A.J., Dolja, V.V., 2002. Interaction between longdistance transport factor and Hsp70-related movement protein of Beet yellows virus. J Virol 76,11003-11011.

Sánchez-Navarro, J.A., Herranz, M.C., Pallas, V., 2005. Cell-to-cell movement of Alfalfa mosaic virus can be mediated by the movement proteins of llar-, bromo-, cucumo-, tobamo- and comoviruses, and does not require virion formation. Virology in press

Sauri, A., Saksena, S., Salgado, J., Johnson, A.E., Mingarro, I., 2005. Double-spanning plant viral movement protein integration into the endoplasmic reticulum membrane is signal recognition particle-dependent, translocon-mediated, and concerted. J Biol Chem 280, 25907-25912.

Schaad, M.C., Jensen, P.E., Carrington, J.C., 1997, Formation of plant RNA virus replication complexes on membranes: role of an endoplasmic reticulum-targeted viral protein. Embo J 16, 4049-4059.

Scholthof, H.B., 2005: Plant virus transport: motions of functional equivalence. Trends Plant Sci10, 376-382.

Skuzeski J.M., Morris T.J., 1995. Quantitative analysis of the binding of Turnip crinkle virus coat 
protein to RNA fails to demonstrate binding specificity but reveals a highly cooperative assembly interaction. Virology 210, 82-90.

Solovyev, A.G., Stroganova, T.A., Zamyatnin, A.A. Jr., Fedorkin, O.N., Schiemann, J., Morozov, S.Y., 2000. Subcellular sorting of small membrane-associated triple gene block proteins: TGBp3-assisted targeting of TGBp2. Virology. 269, 13-27.

Thompson, J.D., Gibson, T.J., Plewniak, F., Jeanmougin, F., Higgins, D.G., 1997. The ClustalX windows interface: flexible strategies for multiple sequence alignment aided by quality analysis tools. Nucleic Acids Res 24:4876-4882

Tusnady, G.E., Simon, I., 1998. Principles governing amino acid composition of integral membrane proteins: application to topology prediction. J Mol Biol 283, 489-506.

Hull, R., 2002. Virus movement through the plant and effects on plant metabolism. In Matthews' plant virology, 4th edn, pp 373-436. Edited by Academic Press, San Diego.

Vaquero, C., Liao, Y. C., Nähring, J., Fisher, R., 1997. Mapping of the RNA-binding domain of the Cucumber mosaic virus movement protein. J Gen Virol 78, 2095-2099.

Verchot-Lubicz J., 2005. A new cell-to-cell transport model for Potexviruses. Mol Plant Microbe Interact 18, 283-290.

Vilar, M., Esteve, V., Pallas, V., Marcos, J.F., Perez-Paya, E., 2001. Structural properties of Carnation mottle virus p7 movement protein and its RNA-binding domain. J Biol Chem 276, 18122-18129.

Vilar, M., Sauri, A., Monne, M., Marcos, J.F., von Heijne, G., Perez-Paya, E., Mingarro, I., 2002. Insertion and topology of a plant viral movement protein in the endoplasmic reticulum membrane. J Biol Chem 277, 23447-23452.

Vilar, M., Sauri, A., Marcos, J.F., Mingarro, I., Perez-Paya, E., 2005. Transient structural ordering of the RNA-binding domain of Carnation mottle virus p7 movement protein modulates nucleic acid binding. ChemBioChem. 6, 1391-6.

Waigmann, E., Ueki, S., Trutnyeva, K., Citovsky, V., 2004. The ins and outs of nondestructive cell-to-cell and systemic movement of plant viruses. Crit Rev Plant Sci 23, 195-250.

Wobbe, K.K., Akgoz, M., Dempsey, D.A., Klessig, D.F. 1998. A single amino acid change in Turnip crinkle virus movement protein p8 affects RNA binding and virulence on Arabidopsis thaliana. J Virol 72, 6247-6250.

Wolf, S., Deom, C.M., Beachy, R.N., Lucas, W.J., 1989. Movement protein of Tobacco mosaic virus modifies plasmodesmatal size exclusion limit. Science 246. 377-379.

Zamyatnin, A.A. Jr., Solovyev, A.G., Savenkov, E.I., Germundsson, A., Sandgren, M., Valkonen, J.P., Morozov, S.Y. 2004. Transient coexpression of individual genes encoded by the triple gene block of potato mop-top virus reveals requirements for TGBp1 trafficking. Mol Plant Microbe Interact 17, 921-930. 


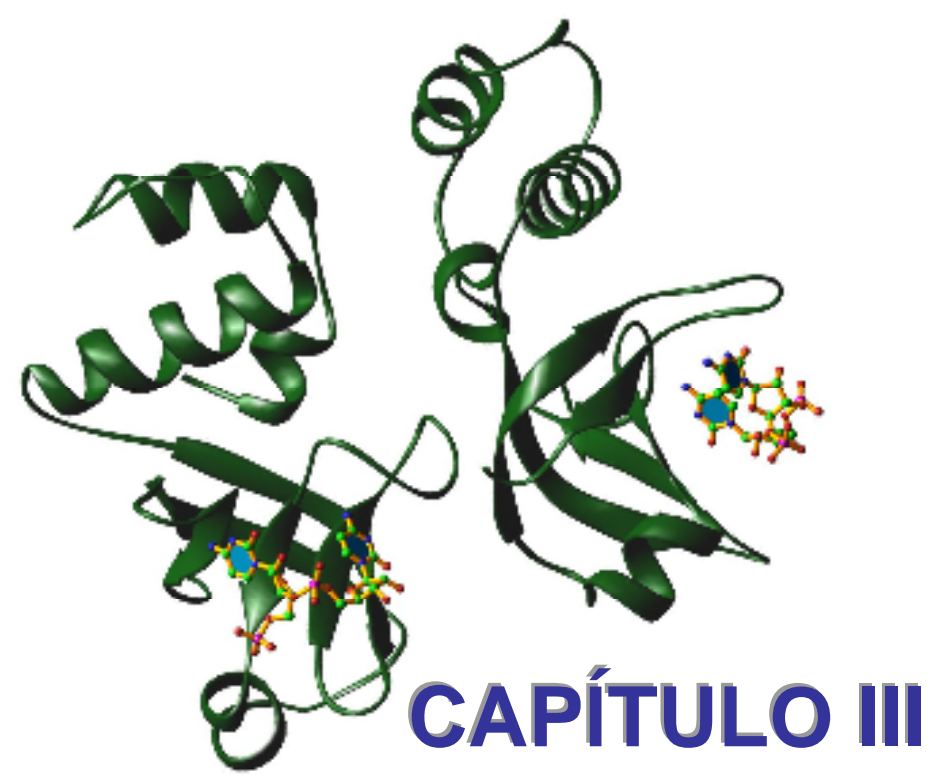




\title{
A Carmovirus movement protein is associated to the Golgi peripheral membrane and its RNA-binding motif is required for the viral cell-to-cell movement
}

\author{
Ainhoa Genovés, José Antonio Navarro and Vicente Pallás \\ Instituto de Biología Molecular y Celular de Plantas (IBMCP). UPV-CSIC, Avda. de los Naranjos, \\ s/n, 46022, Valencia, Spain. \\ Enviado; Journal of Virology
}

\section{ABSTRACT}

Cell-to-cell movement of Melon Necrotic Spot Virus requires two movement proteins (MP), p7A and p7B. The former has been described as a hydrophilic protein essential for the local spread of the infection most likely due to its RNA-binding properties. Two RNA binding themes commonly observed in RNA-protein interactions can be found among the conserved structural elements of this MP: a sequence rich in positively-charged residues that can be induced to fold as a $\alpha$-helix as well as the presence of conserved aromatic residues positioned at the end of a $\beta$-sheet conformation. The disruption of these elements revealed a strong correlation between MNSV cell-to-cell movement and in vitro p7A RNA binding capacity. The subcellular localization of p7A was studied by using a variety of transient and virus vector-based expression systems involving fusions between the p7A and fluorescent reporter proteins combined with microsomal fractionation and bimolecular fluorescence complementation. The p7A was localized at the Golgi stacks even in the absence of any viral factor and later it was observed at the cellular periphery in co-localization with plasmodesmata markers. The possible existence of a Golgi-mediated route assisted by host factors for intracellular movement of this protein is discussed. 


\section{INTRODUCTION}

Most of plant viruses move from cell-to-cell through channels in the cell wall that provide symplastic connections between adjacent cells, known as plasmodesmata (PD). Therefore, the local spread of the infection requires the trafficking of movement-competent viral elements into the correct pathway towards the plasma membrane. To achieve this function, viruses encode one or more non-structural factors known as movement proteins (MPs). Despite the structural differences found among MPs most of them share functional features, such as: the RNA binding capacity; the interaction with viral and host factors and the PD gating (reviewed in Lucas, 2006; Waigmann et al., 2004). Moreover, it has been shown that a particular MP is able to complement the movement deficiency of viruses from unrelated families (Sanchez-Navarro et al., 2006; Scholthof, 2005). In the other hand, a large number of MPs have been identified as membrane proteins often associated to the endoplasmic reticulum (ER)/actin network and the citoskeletal elements suggesting a great dependence on the cell macromolecular transport system for the viral transport (Nelson and Citovsky, 2005). In this sense, plant viruses have developed a variety of strategies to carry out the intracellular movement, for example: the Tobacco mosaic virus (TMV) MP can be targeted to PD most likely using both the ER/actin and microtubules network but without the participation of the Golgi-mediated secretory route (Boyko et al., 2007; Wright et al, 2007); the multi-component transport system of potex-like and hordeilike viruses (the triple gene block, TGB) consisting on three different proteins (TGBp1, TGBp2 and TGBp3) move from ER to the cellular periphery generating mobile ER-derived bodies (Morozov and Solovyev, 2003) and later, some components are recycled by the endocityc pathway (Haupt et al., 2005); finally, it has been established that neither a functional secretory pathway nor an intact cytoskeleton are required for MP targeting to the plasma membrane in some tubule forming viruses (Boevink and Oparka, 2005) although the participation of the secretory transport has been suggested for tubule formation (Laporte et al., 2003; reviewed by Ritzenthaler and Hofman, 2007).

The cell-to-cell movement of carmoviruses requires concerted action of two small proteins, not larger than $12 \mathrm{kDa}$ (Cohen et al., 2000; Genoves et al., 2006) and encoded by a cassette of two genes referred as the double gene block (DGB) (Hull, 2002). The structural and molecular properties of the corresponding gene products (DGBp1 and DGBp2) have been studied in vitro. Biochemical assays have demonstrated that homologous DGBp1, characterized as positively charged proteins, are able to bind single stranded RNA (ssRNA) (Akgoz et al., 2001; Marcos et al., 1999; Navarro et al., 2006; Vilar et al., 2001; Vilar et al., 2005). On the other hand, DGBp2 are integral membrane proteins that anchors in the reticulum endoplasmic trough either singleor two- spanning transmembrane domains (Martínez-Gil et al., 2007; Navarro et al., 2006; Sauri et al., 2005; Vilar et al., 2002). In this scenario, the ability of carmoviruses to move from cell-tocell could be determined by the formation of a hypothetical genome-DGBp1 complex that would 
be assisted by the ER-interacting DGBp2 (Villar et al., 2002). However, speculation concerning this model has been only based on in vitro biochemical data.

The Melon necrotic spot virus (MNSV) has a single-stranded RNA genome of $4.3 \mathrm{~kb}$ wich code for five viral proteins: the p29 and the read-through p89, both involved in virus replication, are released from the genomic-length RNA (gRNA), whereas the small p7A and p7B (DGBp1 and DGBp2, respectively) and the coat protein (p42) are translated from the 1.9 and $1.6 \mathrm{~Kb}$ subgenomic RNAs (sgRNAs), respectively (Genoves et al., 2006; Riviere and Rochon, 1990).

In this investigation, we have addressed further insight in the p7A contribution on virus cell-to-cell movement. For this purpose, we analyzed the involvement of p7A conserved structural elements in spread of the viral infection by amino acid replacements in the p7A sequence of a MNSV vector carrying the green fluorescent protein (GFP). Results revealed a strong correlation between MNSV cell-to-cell movement and p7A RNA binding capacity. In the other hand, we have demonstrated that p7A was initially targeted to the motile Golgi apparatus (GA) stacks and later on the PD-rich areas at the cell periphery in absence of any other viral factor. These last results represent the first clear association of a plant viral movement protein to the GA stacks and can provide new clues on the intracellular transport of plant viruses.

\section{MATERIALS AND METHODS}

\section{Site-directed mutagenesis into p7A ORF.}

All the positively charged amino acids and the conserved $\mathrm{F}_{63} \mathrm{~N}_{64} \mathrm{~F}_{65}$ motif were replaced to alanine as well as the $A_{38} P$ mutation within the p7A open reading frame (ORF) by using pMNSV(Al)- $\Delta$ cp-GFP and pET-p7A as templates (Genoves et al., 2006; Navarro et al., 2006). Mutants were obtained by oligonucleotide-direct mutagenesis using the QuickChangeR XL-Site Direct Mutagenesis Kit (Stratagene, La Jolla, CA) according to the manufacturer protocol and specific primer pairs listed in Supplemental Table 1.

\section{In vitro transcription of MNSV RNAs and inoculation of plants.}

In vitro transcripts derived from all the MNSV constructs were synthesized by T7 RNA polymerase (Roche Diagnostics, Germany) and then, 6-8-days-old Cucumis melo L. subsp. melo cv. Galia and N. benthamiana plants were mechanically inoculated by either rubbing fully expanded cotyledons or young leaves, respectively with the viral RNAs. Two days before, the melon cotyledons were infiltrated with A. tumefaciens carrying pMOG42 (Genoves et al., 2006). In $N$. benthamiana plants, p42 together with the STtmd-ChFP (Syalil transferase trasmembrane domain-Cherry Fluorescent Protein) Golgi marker were expressed by infiltration of $A$. tumefaciens carrying either pMOG42 or pCBNoXbaSTtmdCherry, respectively, but ten hours after viral inoculation. 


\begin{tabular}{|c|c|c|c|}
\hline Mutant & Primer & Sequence $^{\dagger}$ in $5^{\prime}-3^{\prime}$ orientation & Position* \\
\hline \multirow[t]{2}{*}{$\mathrm{K}_{27} \mathrm{~A}$} & VP840 & GGTGACAGCGGGGGAAAACAGGCGAACTCAATGGGG & $2500-2535$ \\
\hline & VP841 & CCCCATTGAGTTCGCCTGTTTTCCCCCGCTGTCACC & $2535-2500$ \\
\hline \multirow[t]{2}{*}{$\mathrm{K}_{33} \mathrm{~A}$} & VP842 & GAACTCAATGGGGCGAGCGATAGCCAATGATGC & $2523-2555$ \\
\hline & VP843 & GCATCATTGGCTATCGCTCGCCCCATTGAGTTC & $2555-2523$ \\
\hline \multirow[t]{2}{*}{$A_{38} P$} & VP844 & GCGAAAGATAGCCAATGATCCTATCTCTGAATCGAAGCAAGG & $2535-2576$ \\
\hline & VP845 & CCTTGCTTCGATTCAGAGATAGGATCATTGGCTATCTTTCGC & $2576-2535$ \\
\hline \multirow[t]{2}{*}{$\mathrm{K}_{43} \mathrm{~A}$} & VP799 & GCTATCTCTGAATCGGCGCAAGGAGTTATGGG & $2555-2585$ \\
\hline & VP800 & CCCATAACTCCTTGCGCCGATTCAGAGATAGC & $2585-2555$ \\
\hline \multirow[t]{2}{*}{$\mathrm{R}_{13} \mathrm{AR}_{15} \mathrm{~A}$} & VP836 & 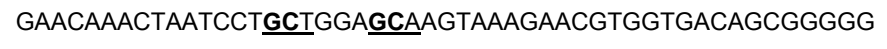 & $2464-2514$ \\
\hline & VP837 & CCCCCGCTGTCACCACGTTCTTTACTIGCTCCAGCAGGATTAGTTTGTTC & 2514-2464 \\
\hline \multirow{2}{*}{$\mathrm{K}_{25} \mathrm{AK}_{27} \mathrm{~A}$} & VP795 & GGTGACAGCGGGGGAGCACAGGCGAACTCAATGGG & $2500-2536$ \\
\hline & VP796 & CCCCATTGAGTTCGCCTGTGCTCCCCCGCTGTCACC & $2536-2500$ \\
\hline \multirow[t]{2}{*}{$\mathrm{R}_{32} \mathrm{AK}_{33} \mathrm{~A}$} & VP797 & GAACTCAATGGGGGCAGCGATAGCCAATGATGC & $2523-2548$ \\
\hline & VP798 & GCATCATTGGCTATCGCTGCCCCCATTGAGTTC & $2548-2523$ \\
\hline \multirow[t]{2}{*}{$\mathrm{K}_{56} \mathrm{AK}_{58} \mathrm{~A}$} & VP801 & 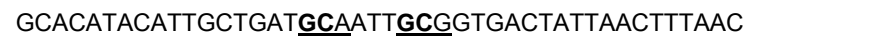 & $2591-2635$ \\
\hline & VP802 & GTTAAAGTTAATAGTCACCGCAATTGCATCAGCAATGTATGTGC & $2635-2591$ \\
\hline \multirow[t]{2}{*}{$\mathrm{F}_{63} \mathrm{AN}_{64} \mathrm{AF}_{65} \mathrm{~A}$} & VP847 & ATTAAGGTGACTATTAACGCTGCCGCTTAGTGTATGGCTTGTTGCCGTTGC & $2611-2661$ \\
\hline & VP846 & GCAACGGCAACAAGCCATACACTAAGCGGCAGCGTTAATAGTCACCTTAAT & $2661-2611$ \\
\hline \multicolumn{2}{|c|}{$\mathbf{R}_{13} \mathrm{AR}_{15} \mathrm{AK}_{17} \mathrm{AR}_{19} \mathrm{~A}$ VP793 } & GAACAAACTAATCCT & $2464-2513$ \\
\hline & VP794 & CCCCCGCTGTCACCAGCTTCTGCACTIGCTCCAGCAGGATTAGTTTGTTC & $2513-2464$ \\
\hline
\end{tabular}

\section{Expression in bacteria, purification and analysis of MNSV p7A mutant forms.}

All pET-p7A constructs were introduced into E.coli strain BL21(DE3) pLysS by electroporation (GenePulser Xcell ${ }^{\mathrm{TM}}$ electroporation system, Bio-Rad). The recombinant His tagged p7A (His-p7A) protein and the mutants were purified by using Ni-NTA agarose and analyzed by SDS-PAGE in $12 \%$ poliacrylamide gels after quantification by absorbance measuring.

\section{Nucleic acid binding assay.}

Protein RNA-binding studies were performed by means of electrophoretic mobility shift assay (EMSA) as previously described (Herranz and Pallas, 2004). Briefly, different concentrations of either the His-tagged p7A or the mutants were incubated $30 \mathrm{~min}$ at room temperature with a digoxigenin-labeled plus-strand MNSV RNA (Gosalvez et al., 2003) in a 10

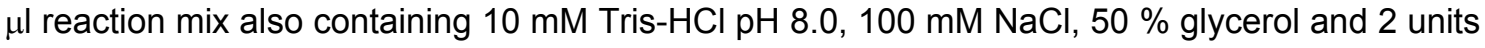
of RNase inhibitor. Afterwards, samples were electrophoresed on a $1 \%$ agarose gel in $1 \mathrm{XTAE}$ buffer (40 mM Tris-acetate, $1 \mathrm{mM}$ EDTA, pH 8.0), capillary-transferred to nylon membranes (Roche Diagnostics $\mathrm{GmbH})$ in the presence of $10 \mathrm{XSC}(1,5 \mathrm{M} \mathrm{NaCl}, 0,15 \mathrm{M}$ sodium citrate) and exposed to UV irradiation $(700 \times 100 \mu \mathrm{J} / \mathrm{cm} 2)$ to cross-link RNA. Riboprobe detection was conducted as previously described (Pallás et al., 1998). 


\section{Construction of recombinant MNSV-AI and MNSV-AI/264 CDNA clones.}

The cDNA corresponding to the 3' termini of MNSV-264 gRNA were obtained by RT-PCR of total RNAs isolated from leaves of melon plants infected with MNSV-264 isolate (Diaz et al., 2004) and purified after electrophoretic separation on polyacrylamide gels. After restriction with the appropriate endonucleases, the MNSV-264 3' UTR was inserted into pMNSV(Al) which 3' UTR was previously removed to generate the recombinant pMNSV(Al/264) clone. The sequences of both MNSV-264-specific primers were obtained from GenBank database (accession number AY330700). In the case of recombinant GFP and GFP-p7A MNSV(Al/264) clones, the p42 gene from pMNSV(Al/264) clone was either replaced by the GFP or by the

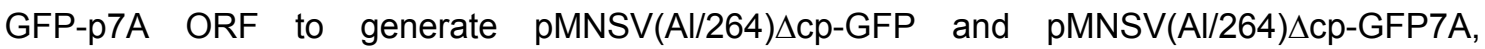
respectively. For the pMNSV(Al) $\Delta c p-G F P p 7 A$ clone, the p42 gene was replaced by the GFPp7A ORF.

\section{Agrobacterium tumefaciens-mediated transient expression assays and bimolecular fluorescent complementation}

cDNAs of recombinant proteins corresponding to GFP-p7A (green fluorescent protein fused in frame to the amino terminus of the p7A), $\mathrm{N}_{\mathrm{t}}-[Y F P]-p 7 A$ and $\mathrm{C}_{\mathrm{t}}-[Y F P]-p 7 A$ consisting on an amino-terminal yellow fluorescent protein (YFP) fragment (residues 1-155, referred to as $\mathrm{N}_{t^{-}}$ [YFP]) and a carboxyl-terminal YFP fragment (residues 156-238, referred to as $\mathrm{C}_{\mathrm{t}}$-[YFP]) fused to the amino terminus of the p7A were obtained by standard procedures. All these recombinant proteins together with the $\mathrm{N}_{\mathrm{t}}$-[YFP] and $\mathrm{C}_{\mathrm{t}}$-[YFP] fragments were inserted in the binary vector pMOG800 under the control of the Cauliflower mosaic virus (CaMV) 35S promoter (Knoester et al., 1998). Additionally, expression cassettes containing the $\mathrm{N}_{\mathrm{t}}-[\mathrm{YFP}]$ and $\mathrm{C}_{\mathrm{t}}-[\mathrm{YFP}]$ fused to the $\mathrm{N}$-terminal signal peptide sequence of Arabidopsis thaliana basic chitinase and the $\mathrm{C}$-terminal ER-retention signal HDEL were obtained from pRT-YN-ER and pRT-YC-ER, respectively and cloned into pMOG800. pRT-YN-ER and pRT-YC-ER were kindly provided by Dr Jari P. T. Valkonen (University of Helsinki, Department of Applied Biology, Helsinki, Finland). The previously described binary constructs together with the pMOG(GFP) carrying GFP expression cassette, (Herranz et al., 2005), were introduced into Agrobacterium tumefaciens strain C58C1 by electroporation (GenePulser Xcell ${ }^{\mathrm{TM}}$ electroporation system, Bio-Rad). Transient expression assay on $N$. benthamiana plants was performed as previously described (Sánchez-Navarro et al., 2006). For experiments requiring co-infection of more than one construct, bacterial strains containing the constructs were mixed before performing the leaf infiltration, with the inoculum of each construct adjusted to the required final $\mathrm{OD}_{600}$. Infiltrated plants were kept in grown chambers in $16 \mathrm{~h} \mathrm{light} \mathrm{at} 25^{\circ} \mathrm{C}$ and $8 \mathrm{~h}$ dark at $22^{\circ} \mathrm{C}$.

\section{Microsomal fractionation and immunoblotting.}

Microsomal fraction (P30) of extracts from approximately $2 \mathrm{~g}$ of $\mathrm{N}$. bentathamiana leaves transiently expressing either GFP or GFP-p7A were performed in the presence of $5 \mathrm{mM} \mathrm{MgCl}_{2}$ 
as previously described (Peremyslov et al., 2004). Immunoblot was done using mouse polyclonal antibody to GFP (Roche Diagnostics, Germany).

\section{Fluorescent microscopy}

All imaging was conducted on a Leica TCS SL confocal laser-scaning microscope using an HCX APO 40x/0.90 w water dipping lens to study the subcelular localization of the fluorescent tagged proteins. GFP and YFP fluorescence was visualized by $488 \mathrm{~nm}$ excitation with a $\mathrm{Kr} / \mathrm{Ar}$ laser and its emission was examined with a bandpass filter for 500-520 nm. For imaging of ChFP and mRFP fluorescence excitation at $514 \mathrm{~nm}$ was used and emission examined at 600-620. When indicate, successive serial images were recorded along the $Z$ axis of the microscope over a range of $N$. benthamiana epidermal cell planes and finally merged to be displayed.

\section{RESULTS}

\section{Mutational analysis of p7A function in MNSV cell-to-cell movement.}

The p7A is a positively charged protein structured in three conserved domains among carmoviruses: an unordered $\mathrm{N}$-terminus, an inducible $\alpha$-helical central region and a $\mathrm{C}$-terminus with a potential $\beta$-sheet folding that exhibits the highest degree of sequence similarity and the conserved motif FNF (Marcos et al., 1999; Vilar et al., 2001; Navarro et al., 2006) (Figure 1). Here, alanine-scanning mutagenesis was used to map structure-to-function relationships through the entire $p 7 A$ sequence. The mutant $p 7 A$ variants were engineered into a recombinant cDNA clone of MNSV tagged via insertion of GFP reporter gene instead of the CP ORF, since the CP was reported not to be essential for cell-to-cell movement although favoured it, most likely due to its capacity to delay the RNA silencing mechanism (Genoves et al., 2006). The RNAs derived from modified pMNSV(Al)- $\Delta$ cp-GFP clones were inoculated onto melon cotyledons that, in order to avoid any potential detrimental effect caused by the absence of the $\mathrm{CP}$, were previously agro-infiltrated with the CP-expressing construct pMOG42. Approximately 20 to 30 individual infection foci of at least five different plants were analyzed for each of the MNSV variants at 2-3 days post inoculation (dpi). Local spread was measured by quantifying the fluorescent area.

As observed in Figure 1, each of the mutations, either single or double, introduced into the p7A central domain resulted in the complete inhibition of virus cell-to-cell movement, except for the $\mathrm{K}_{43} \mathrm{~A}$ mutant that reduced it approximately to $65 \%$. Instead, double mutants at the $\mathrm{p} 7 \mathrm{~A}$ amino- and carboxyl-terminal regions slowed down local spread approximately to $70 \%$, moreover, the combination of both mutants resulted in a considerable reduction to $34 \%$ (Figure 1). Nevertheless, the movement was abolished after four A replacements of positively charged 
residues within the protein $\mathrm{N}$-terminus (Figure 1). These results indicate that p7A function in MNSV movement is given by positively charged residues of its sequence, especially those within the protein central domain.

In the other hand, it is well characterized that p7A central domain derived peptide, $\mathrm{p} 7 \mathrm{~A}_{23-}$ ${ }_{44}$, can be induced to fold into a $\alpha$-helical conformation (Navarro et al., 2006). Moreover, the significance of $\alpha$-helix in the protein RNA-binding properties has been demonstrated for the RNA binding domain (RBD) of the CarMV homologous movement protein p7 (Vilar et al., 2005). Thus, the replacement of $A_{38}$ with $P$ in p7A should preclude the adoption of the $\alpha$-helical structure of the central domain, as occurs in p7 (Vilar et al., 2005). As expected, only individual fluorescent cells were observed when the RNAs derived from this construct were inoculated (Figure 1). Finally, the replacement of the p7A consensus motif FNF with $A$ residues resulted in the block of virus local movement (Figure 1). These results underscore the critical nature of the p7A $\alpha$-helical structure and FNF motif revealing that they are essential for the MNSV cell-to-cell movement.

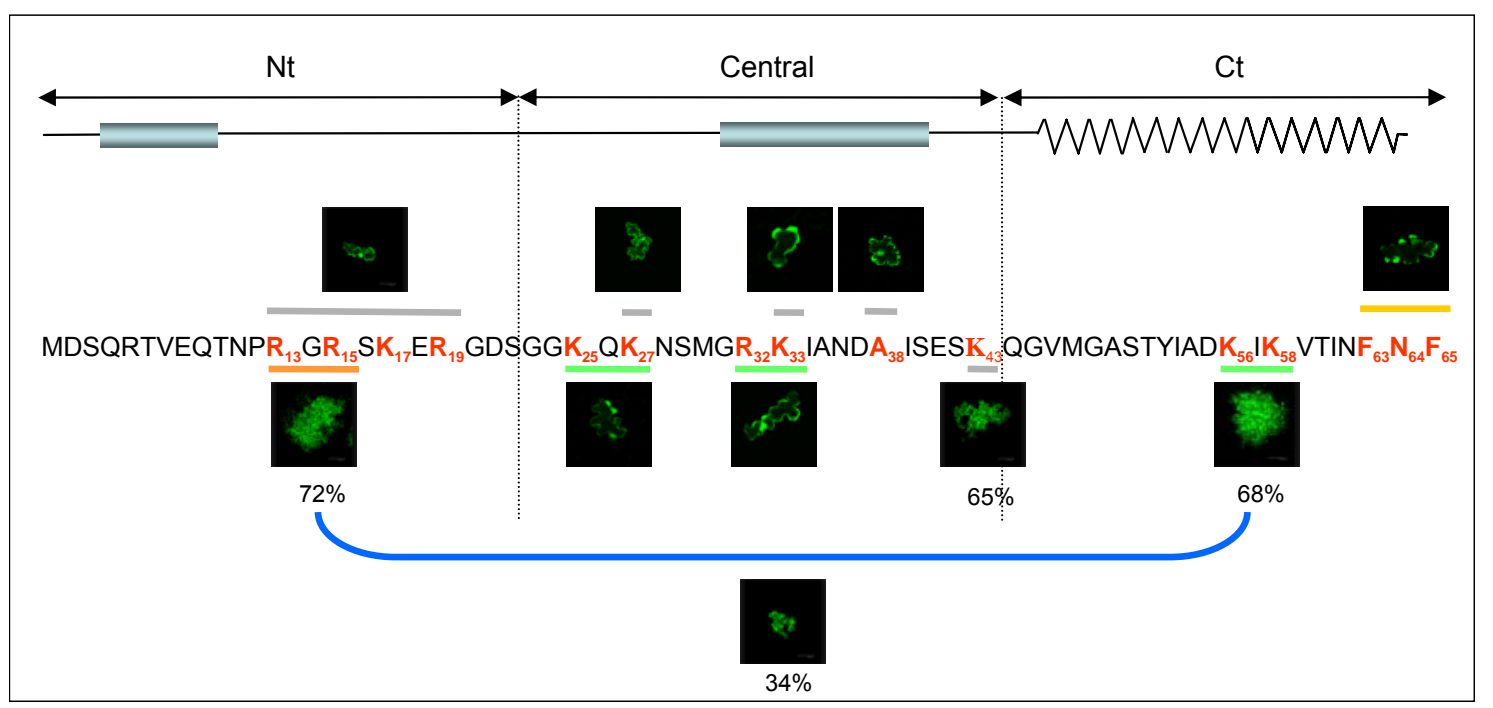

Figure 1. Site-directed mutagenesis analyses of p7A function in MNSV cell-to-cell movement in melon plants. A schematic representation of the secondary structure of the p7A showing the three different structural regions separated by dotted lines is displayed in the upper side of the figure. The conserved $\alpha$-helix and $\beta$-sheet structures are represented by boxes and broken lines, respectively. Below the scheme, a diagrammatic presentation of the results from the p7A site-directed mutagenesis analysis is presented. The residues that were modified in p7A ORF into the pMNSV(Al) $\Delta$ cp-GFP construct are showed in red and their relative position is indicated by a subheading number. Moreover, the number of replacements generated in each mutant are indicated over and underlined in p7A sequence. Combination of mutants $R_{13} A R_{15} A$ and $K_{56} A K_{58} A$ is indicated by using a key. All of the modifications consisted on alanine replacements except for $A_{38} P$. An image of a representative fluorescent infection focus taken 2-3 days after inoculation of each MNSV mutant RNAs on melon cotyledons by using a confocal laser microscope is shown. The percentages below the images indicate the infected tissue area generated by each mutant relative to that produced by the original MNSV RNA. No percentage indicated the appearance of unicellular foci.

In order to discard that the mutant p7A variants were affected in the virus replication, fluorescent area generated by the mutants with reduced movement was cut, discarding non- 
infected tissue, and total RNAs were extracted. Northern-blot hybridisation with an antisense specific ribobrope from GFP revealed that the MNSV RNAs were multiplied and accumulated at approximately the same amounts, indicating that viral replication was not affected (data not shown).

\section{The p7A RNA binding capacity is required for MNSV cell-to-cell movement.}

The in vitro RNA-binding activity of the p7A suggests that it might be involved in the formation of the MNSV genome-MP complex in vivo (Navarro et al., 2006). Therefore, the differences in the infection spread among mutant p7A variants could be a direct consequence of its RNA-binding capabilities. To further evaluate this possibility, the in vitro RNA-binding properties of the p7A variants were analyzed by in vitro electrophoretic mobility shift assay (EMSA). The EMSA were performed using a MNSV-specific DIG-labelled SSRNA riboprobe and increasing amounts of either a His-tagged p7A (referred afterwards as wt p7A) expressed from pET-p7A construct (Navarro et al., 2006) or the His-tagged p7A variants obtained by pET-p7A alanine-scanning mutagenesis (Figure $2 \mathrm{~A}$ ). For wt p7A, all added RNAs were quickly converted to a slightly-retarded intermediate complex (IC) even at very low quantities of the protein ( $<1 \mathrm{ng}$ ) (data not shown), however, with increasing amounts IC was progressively disappearing as a fully-retarded complex (FC) that hardly enters in the gel. This FC was initially detected in the presence of $10 \mathrm{ng}$ of protein whereas the IC practically disappeared when $160 \mathrm{ng}$ of protein were added to the binding mixture (Figure 2B). Similar complexes have been described either for viral (for example; Infectious bronchitis virus, IBV nucleocapsid and Poa semilatent virus, PSLV TGBp1) or for non-viral proteins (the major core informosome protein associated with eukaryotic mRNA p50) (Kalinina et al., 2001; Osborne and Elliot, 2000). Moreover, in the case of PSLV TGBp1, the fully and partially retarded complexes showed distinct shapes as were imaged by atomic force microscopy (Kalinina et al., 2001).

The RNA-binding ability of the p7A central domain mutant $R_{32} A K{ }_{33} A$ was drastically inhibited (Figure 2D) even at $600 \mathrm{ng}$ of protein (data not shown) whereas the $\mathrm{N}$ terminus $R_{13} A R_{15} A$ substitution had negligible effect on the RNA-binding process (Figure $2 C$ ). When the central $\alpha$-helix was disrupted in the ${ }_{38} \mathrm{P}$ mutant, the RNA binding capacity also disappeared (Figure $2 \mathrm{E}$ ) indicating the requirement of the secondary structure element for this property. Finally, p7A C- terminus mutant $\mathrm{F}_{63} \mathrm{AN}_{64} \mathrm{AF}_{65} \mathrm{~A}$ (Figure $2 \mathrm{~F}$ ), although still able to bind $\mathrm{RNA}$, did it with an apparent dissociation constant $(\mathrm{Kd}=1.7 \mu \mathrm{M}) 6$-fold higher than that obtained for both p7A and $R_{13} A R_{15} A(0.3 \mu \mathrm{M}$ and $0.28 \mu \mathrm{M}$, respectively). Taken together, the results presented above establish a direct correlation between the RNA binding capacity of the p7A and the viral cell-to cell movement, except in the case of the conserved FNF motif mutant which is probably involved in other p7A quality necessary in the viral movement. 


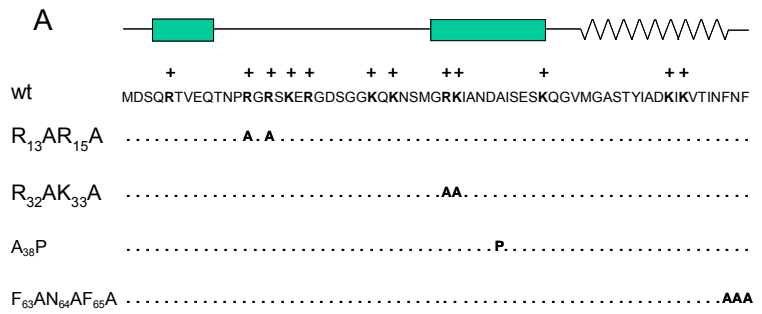

C

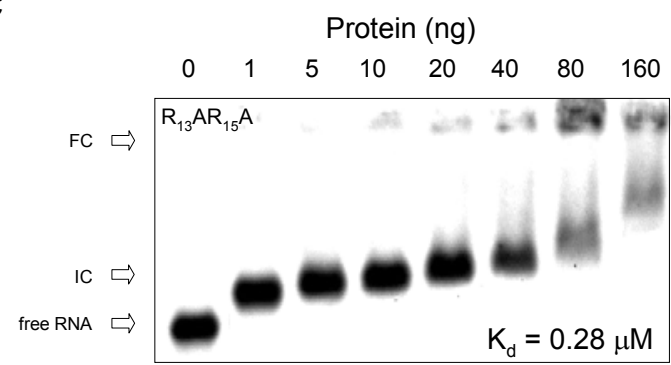

$\mathrm{E}$

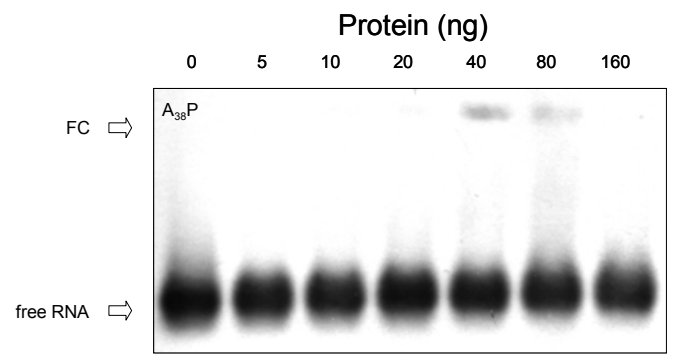

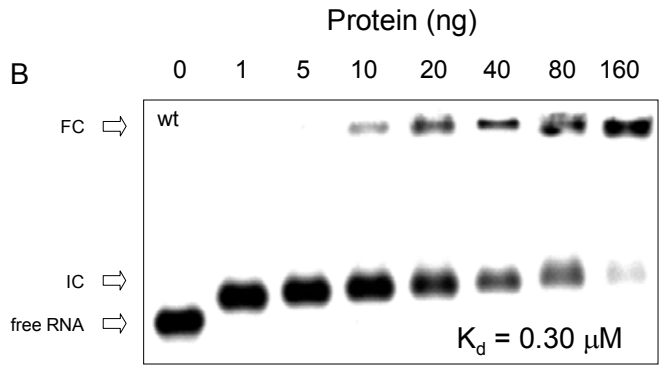

D $\quad$ Protein $(\mathrm{ng})$

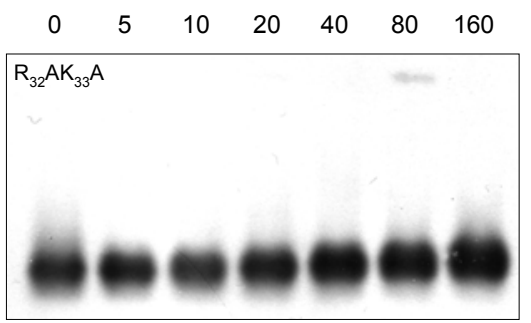

$\mathrm{F}$

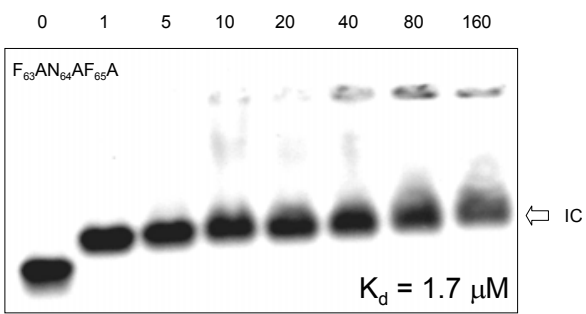

Figure 2. Comparison of in vitro RNA binding properties between the His-tagged p7A and some representative Histagged p7A variants by electrophoretic mobility shift assays (EMSA). A) Schematic representation of the p7A structure as in Figure 1 showing the location of basic residues (K or $R$ ) by + symbols and the representative p7A mutants which were selected to study their RNA-binding properties by EMSA. A representative EMSA from wild-type (wt) and each p7A mutant are presented: B) EMSA from wild-type p7A, C and D) EMSA from two-positively charged to alanine replacements located either at the amino termini (left) or at the central region (right) of p7A. E) EMSA from $A_{38} P$ p7A mutant and $F$ ) EMSA from $F_{63} A_{N_{64}} A_{65} A$ p7A mutant. The position of free $R N A$, intermediate (IC) and fully retarded (FC) complexes are indicated. $K_{d}$ of the His-p7A/RNA formation was determined by Hill transformation of data from three independent EMSA.

\section{Subcellular localization of tagged p7A during infection in N. benthamiana leaves.}

To further elucidate the p7A properties that make this protein necessary for the viral movement we addressed the subcellular localization of a GFP-tagged p7A in a MNSV infection background. After inoculation of run-off transcripts derived from the clone pMNSV(Al)- $\Delta \mathrm{cp}-$ GFP7A over melon cotyledons, punctuate fluorescent bodies were observed within the cytoplasm (Figure $3 A-C$ ) and the periphery (Figure 3D-E) of the infected cells. The identification of this protein pattern requires the transient expression of well-establish subcellular markers for co-localization assays (Haupt et al., 2005). In this scenario, the experimental host was changed to $N$. benthamina, commonly used in subcellular studies of plant viral movement proteins. This plant is host for isolate MNSV-264, which possesses an avirulence determinant in its 3'-UTR 
allowing the infection of non-cucurbit species (Diaz et al., 2004). Thus, the pMNSV(Al) clone was modified by replacing its 3'-UTR from that of the isolate MNSV-264 (pMNSV(Al)/264). The inoculation of $N$. benthamiana leaves with transcripts derived from pMNSV(Al)/264 resulted in the development of both local and systemic infection symptoms. As expected, Northern-blot hybridization of RNA extracted from the infected tissue with an antisense specific ribobrope from 3'-UTR of isolate MNSV-264 revealed that the genomic and both subgenomic RNAs were multiplied (data not shown).
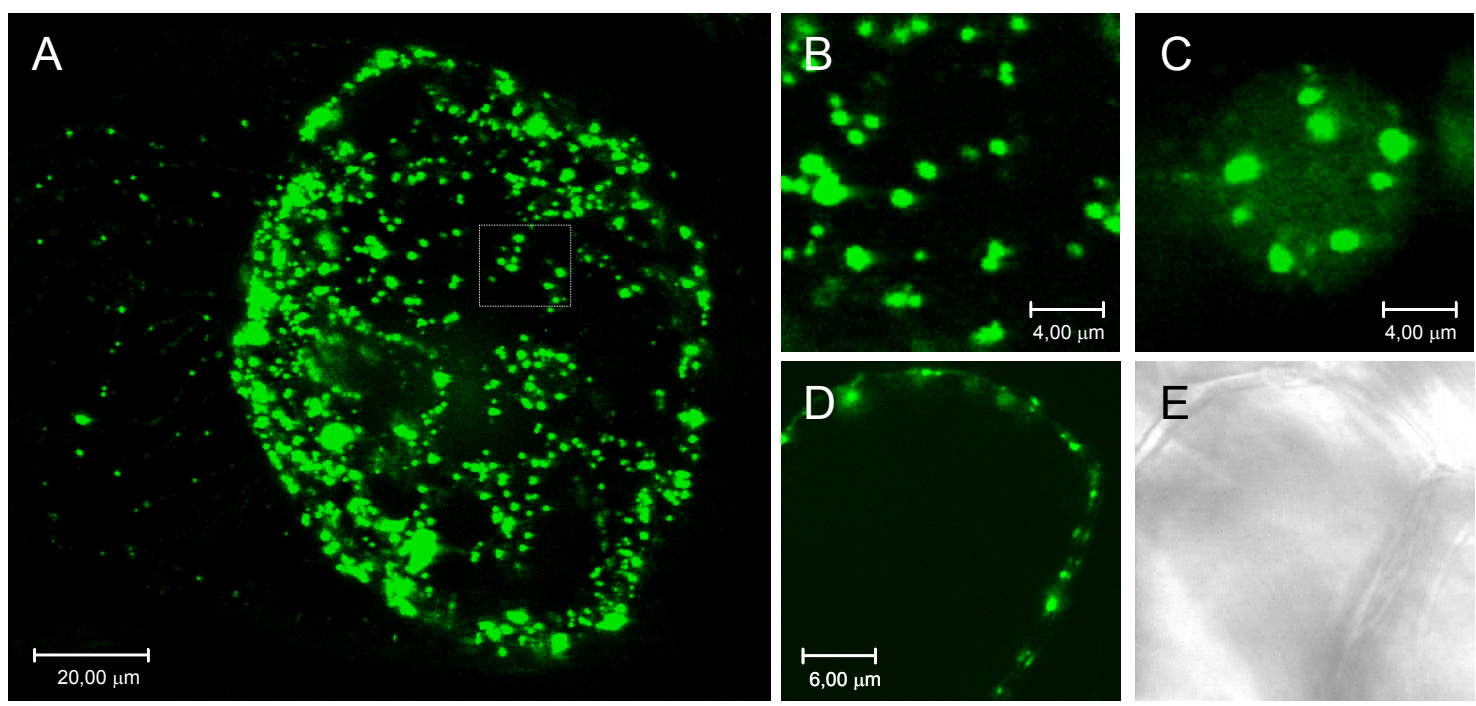

Figure 3. Subcellular localization of GFP tagged p7A by MNSV-derived vector expression in cotyledons of Cucumis melo L. subsp. melo cv. Galia. A) Confocal laser image resulted from serial projection of 30 recorded scans $(10 \mu \mathrm{M}$ deep) of an individual epidermal cell from infection foci generated by inoculation of in vitro transcripts derived from the pMNSV(Al)- $\Delta$ cp-GFP-p7A onto melon cotyledons. The area inside the inset has been enlarged in a new scan to clearly show the fluorescent bodies (panel B) and the absence of signal inside the nucleus (panel C). D) Confocal laser enlarged scan showing the localization of fluorescent paired structures at both sides of the cell wall produced by GFPp7A at the boundary between two adjacent cells (see the white light image at the panel E).

Once demonstrated the viability of this quimera construct, it was replaced the p42 ORF either by the GFP ORF (pMNSV(Al)- $\Delta \mathrm{cp}-\mathrm{GFP} / 264$ ) or by the GFP-p7A ORF (pMNSV(Al)- $\Delta \mathrm{cp}-$ GFP-p7A/264), respectively. The expression of the GFP or GFPp7A is driven by sgRNA 2, generated after virus replication. After inoculation of run-off transcripts derived from pMNSV(AI)$\Delta$ cp-GFP/264 over $N$. benthamiana leaves, no local lesions were seen but fluorescent infection foci were observed. These results indicate that the chimeric RNAs were able not only to replicate but also to move from cell-to-cell in the absence of $\mathrm{CP}$, as stated above for melon infection. After 2-3 dpi, confocal laser scanning microscopy revealed that the GFP was uniformly distributed among cytoplasm and nuclei of infected cells but, interestingly, the GFPp7A was also detected in motile granules within the cell cytoplasm (Figure 4A) trafficking in particular directions, most likely along the actin microfilaments (Figure 4B-C). Moreover, at later infection stages (3-4 dpi) the fluorescent signal was also observed as aggregates localized 
primarily close to the cell plasma membrane (Figure 4D) that occasionally resembled cell wall embedded punctuate bodies (Figure 4E). This pattern distribution resembles that of Golgi apparatus (GA) stacks (Saint-Jore-Dupas et al., 2004).
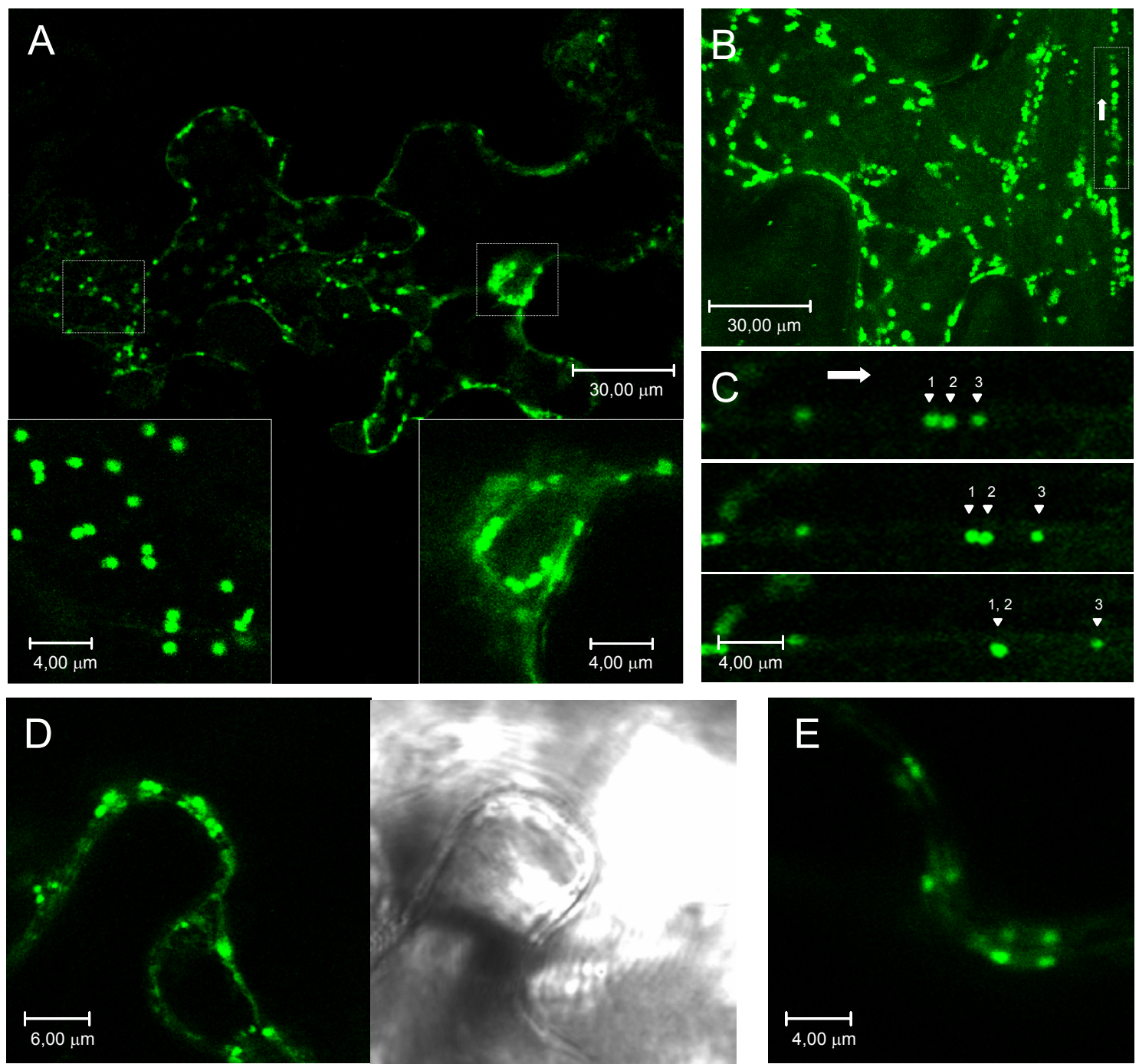

Figure 4. Subcellular localization of GFP tagged p7A by MNSV-derived vector expression. A) Confocal laser scan of an individual epidermal cell from infection foci generated by inoculation of in vitro transcripts derived from the pMNSVAI/264) $\Delta$ cp-GFP-p7A onto $N$. benthamiana leaves. The areas inside the insets have been enlarged in new scans to clearly show the fluorescent bodies and the absence of signal inside the nucleus. B) Confocal laser image resulted from serial projection of 30 recorded scans $(10 \mu \mathrm{M}$ deep) of an epidermal cell showing the motile bodies trafficking in a particular direction most likely along the actin filaments. The movement of 3 bodies (indicated with arrows and numbers 1,2, and 3) located inside the inset was followed by three consecutive scans of the same confocal plane and enlarged in panel C. D) Confocal laser enlarged scan showing the localization of fluorescent aggregates produced by GFP-p7A (left side image) at the boundary between two adjacent cells (white light image at right side) and a different scan showing fluorescent punctuate structures generated by GFP-p7A at both sides of the cell wall in panel E.

To corroborate the identity of these bodies as GA stacks a co-localization assay was performed consisting on the infection of $N$. benthamiana leaves with MNSV(Al)- $\Delta$ cp-GFPp7A/264 RNAs and after that, when the infected leaves recuperated their vigour, the STtmdChFP (Syalil transferase trasmembrane domain-Cherry Fluorescent Protein) marker was transiently expressed by agro-infection. Note that the STtmd is well established as a trans GA 
marker in plants (Wee et al., 1998). After 24 to 48 hours, co-localization of the red and green signals was observed (Figure 5A-C) revealing tight association of the GFPp7A granules and the GA stacks, even that the p7A is a soluble protein.

Considering that the p7A is lacking hydrophobic domains, it was decided to investigate whether its association to GA stacks could be mediated by the presence of the DGBcounterpart membrane-associated protein (p7B). For this purpose, a frame-shift mutation was introduced in position 2646 of the pMNSV(Al)- $\Delta$ cp-GFP-p7A/264 construct to impede the synthesis of p7B (Genoves et al., 2006). Run-off transcripts derived from this clone were used in a GFP-p7A/STtmd-ChFP co-localization assay as described before. No modification of the subcellular localization of GFP-p7A was observed (Figure 5D-F) suggesting that either other MNSV proteins, as the replicases, or host factors are involved in the GA stacks and cellular periphery targeting of $\mathrm{p} 7 \mathrm{~A}$.

GFP-p7A
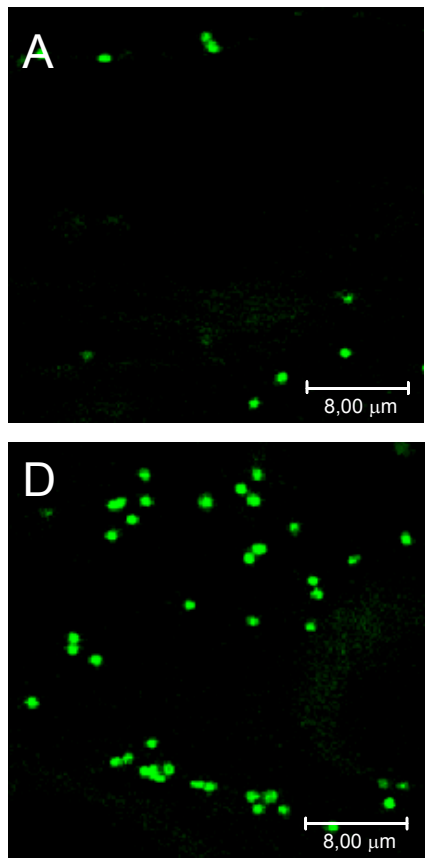

STtmd-ChFP
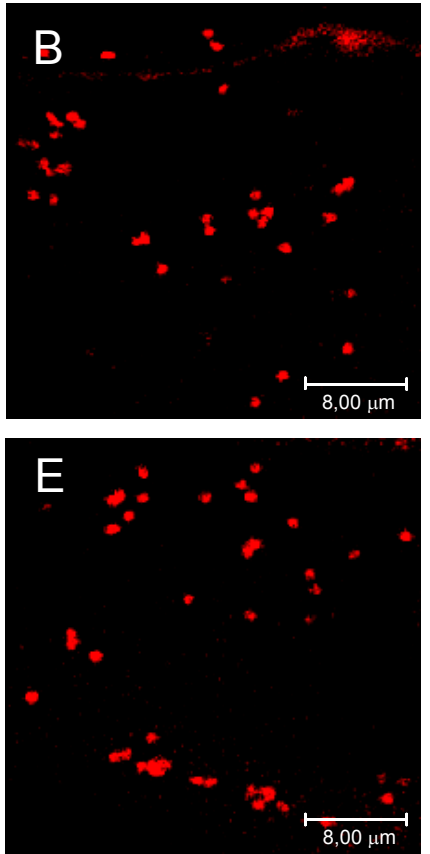

Overlay
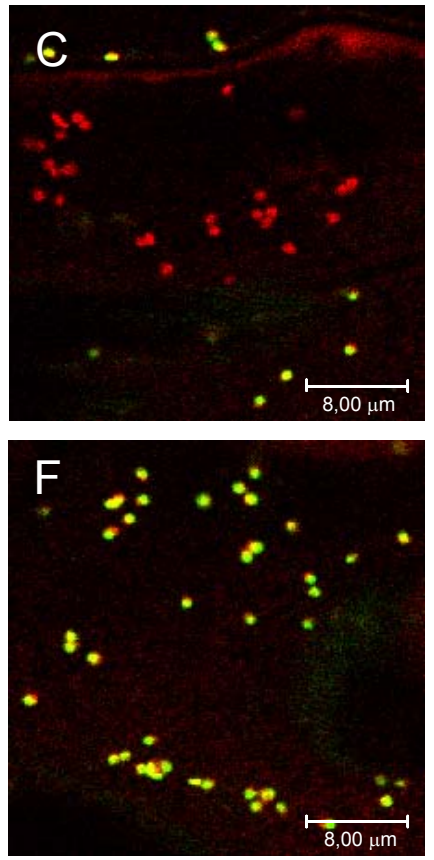

Figure 5. Identification of GFP-p7A motile granules as Golgi stacks by fluorescence co-localization assays with STtmdChFP subcellular marker in $N$. benthamiana leaves. A and $D$, confocal laser scan showing the bodies generated by GFP-p7A expression from viral infection with viral RNAs derived from the original and the p7B deficient pMNSV(Al/264) cp-GFP-p7A construct, respectively. B and E) Identical confocal laser scan registering the red fluorescence staining of Golgi stacks by the (bandpass of 600-620 nm) transient expression mediated by agroinfection of STtmd-ChFP. C and F) Merged image of panel A and B (panel C) as well as that resulting from panels D and $E$ overlay (panel F) showing co-localization of GFP-p7A bodies and STtmd-ChFP labeled Golgi stacks. 


\section{Subcellular localization of tagged p7A by A. tumefaciens-mediated expression reveals non-viral factor requirements for the Golgi association.}

The recombinant protein GFP-p7A, as well as the GFP were expressed transiently in $N$. benthamiana leaves by agro-infiltration. The anti-GFP immunoblot analysis of the subcellular fractionation of extracts derived from expressing tissue (Peremyslov et al., 2004) revealed that the distribution of both proteins was quite different (Figures 6A and D). As expected, all the free GFP was present in the soluble fraction (S30) but the GFPp7A was detected in this soluble fraction and predominantly associated to the insoluble pellet (P30), which mainly contains membranous material and cell organelles. Interestingly, in the P30 fraction it was observed possible multimeric forms of the protein, referred as GFP-p7A dimmers (GFP-p7A/D) and oligomers (GFP-p7A/O) (Figure 6D). These results suggest that the protein could associate with membrane organelle in agreement with the subcellular location of the GFP-7A expressed during a MNSV infection. Moreover, confocal laser scanning microscopy revealed that the distribution pattern of the fluorescence from the cells expressing GFP-p7A (Figures 6E and F) was different from the cells expressing free GFP (Figures $6 B$ and $C$ ). As indicated the subcellular fractionation, this fusion protein (GFPp7A) was detected in the cell soluble fraction (cytoplasm and nucleus); however, it was also observed in punctuate structures (Figures 6F and $\mathrm{G}$ ) that colocalized with STtmd-ChFP (Figures 6G-I). Moreover, fluorescent structures could be observed as granulates at the cell periphery (Figure $6 \mathrm{~J}$ ), which co-localized with the MP of Tobacco mosaic virus, TMV, (Figures 6J-L), a well-characterized PD marker protein (Waigmann et al., 1994) These results indicate that the distribution pattern previously observed with GFPp7A expressed from the viral RNA is also observed with the transiently expression of the fusion protein carried out in absence of any other viral factor. Nevertheless, in this case GFPp7A was also observed in the soluble fraction.

In the other hand, the detection of the GFP-p7A as multimers strongly suggested the existence of self-interaction for p7A and thus, further studies on p7A subcellular localization in the absence of viral factors were performed by using the Bimolecular Fluorescence Complementation (BiFC) assay (Citovsky et al., 2006). For this purpose, it was fused either an amino-terminal or a carboxyl-terminal Yellow Fluorescent protein (YFP) to the amino terminus of the p7A to generate $\mathrm{N}_{\mathrm{t}}-[\mathrm{YFP}]-\mathrm{p} 7 \mathrm{~A}$ and $\mathrm{C}_{\mathrm{t}}-[\mathrm{YFP}]-\mathrm{p} 7 \mathrm{~A}$ recombinant proteins, respectively. Two days after the Agrobacterium-mediated co-expression of both half-YFP-tagged $p 7 A$, it was observed a fluorescent signal located at particular granules that actively moved throughout the cytoplasm of $N$. benthamiana epidermal cells (Figure 7A) whereas the expression of each recombinant protein alone did no produce any detectable fluorescent signal (data not shown). Three days later, the fluorescent signal was also observed as aggregates localized primarily close to the plasma membrane (Figure 7B-C). Moreover, the identity of these p7A-mobile bodies as GA stacks was confirmed by co-localization of the green signal from both $\mathrm{N}_{\mathrm{t}}$-[YFP]p7A and $C_{t}-[Y F P]-p 7 A$ expressed together with the red signal from the recombinant protein STtmd-ChFP (Figure 7D-F). 


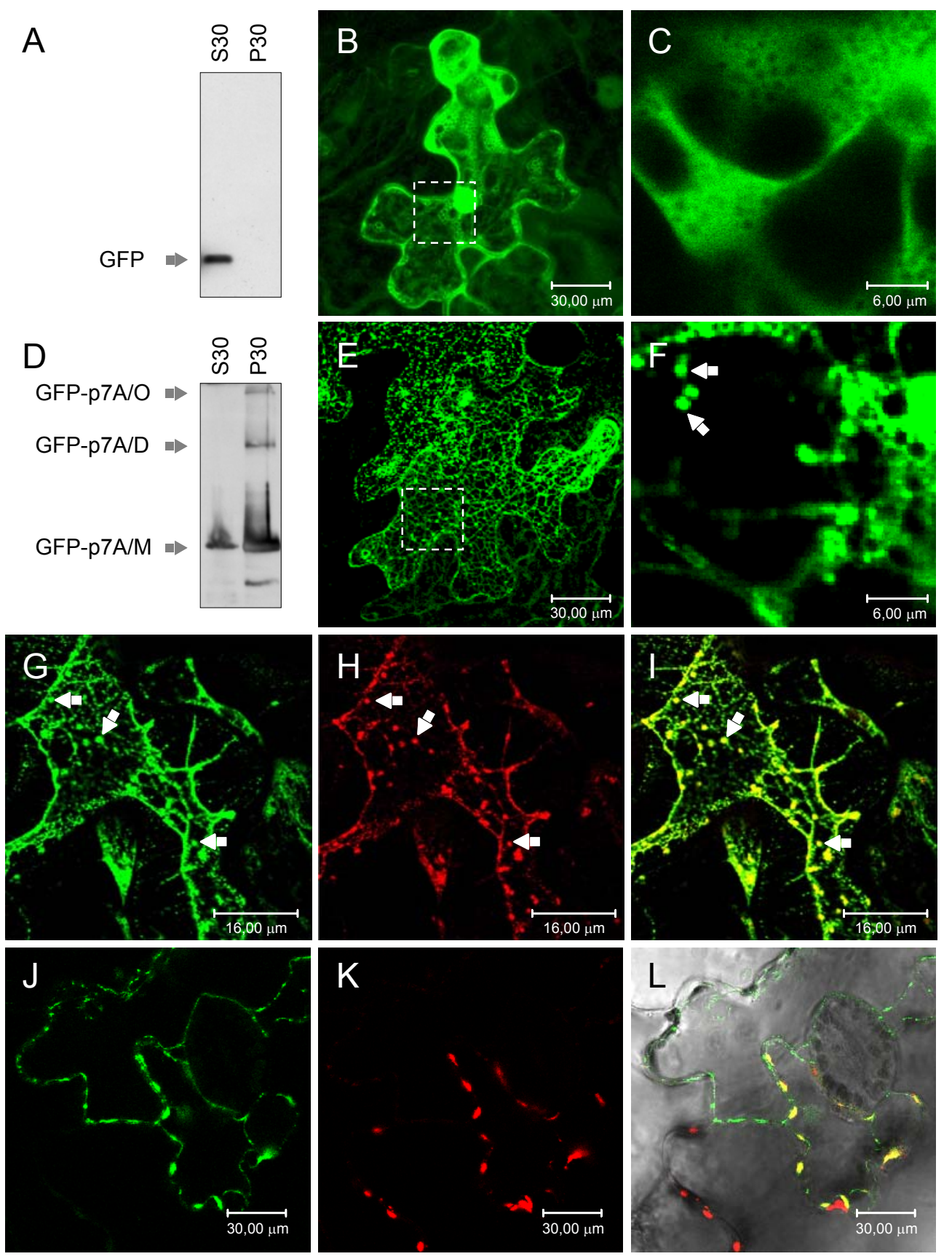

Figure 6. Analysis of the subcellular localization of different fluorescent tagged p7A in the absence of viral factors by means of the transient expression mediated by $A$. tumefaciens infection in $N$. benthamiana leaves. $A$ and $D$ ) Immunoblotting of microsomal fractionation of $N$. bentramiana leaves transiently expressing either GFP or GFP-p7A, respectively. $B$ and $E$ ) Confocal laser images resulting from the serial projection of 30 recorded scans (10 $\mu \mathrm{M}$ deep) of an epidermal cell showing the fluorescence distribution obtained when either the GFP (panel B) or the GFP-p7A (panel E) were expressed. The areas inside the insets have been enlarged in new scans to clearly show the presence of the fluorescent bodies in GFP-p7A expression (pointed by arrows in panel F) but their absence inside the cells expressing GFP (panel C). G to I) Identification of the fluorescent bodies observed by agro-expression of GFP-7A in N. benthamiana leaves as Golgi stacks by fluorescence co-localization assays with STtmd-ChFP subcellular marker. G and $\mathrm{H}$ ) Identical confocal laser scan registering the green and the red fluorescence staining of Golgi stacks by the transient expression mediated by agro-infection of both GFP-p7A (green) and STtmd-ChFP (red), respectively. I) Merged image of panel $\mathrm{G}$ and $\mathrm{H}$ showing co-localization of GFP-p7A bodies and STtmd-ChFP labeled Golgi stacks (some of them pointed by arrows). $\mathrm{J}$ to $\mathrm{L}$ ) Confocal laser scans of epidermal cells co-expressing GFP-p7A and the Tobacco mosaic virus movement protein fused to the mRFP ORF (MPTMV-mRFP) as plasmodesmal marker. Overlay images of the red, the green and the white light channels showing colocalization of the viral protein and the PD marker on the boundaries between adjacent epidermic cells are displayed in the panel $\mathrm{L}$. 
It has been described that the non-fluorescent half-YFP fragments are able to form fluorescent complexes by self-assembly in the absence of any specific interaction (Walter et al., 2004). Moreover, the re-assembly efficiency between these non-interacting YFP fragments can be increased either by concentrating both $\mathrm{N}_{\mathrm{t}}$-[YFP] and $\mathrm{C}_{\mathrm{t}^{-}}[\mathrm{YFP}]$ into a cellular compartment as the ER luminal space (Zamyatnin et al., 2006). Indeed, when $\mathrm{N}_{\mathrm{t}}-[\mathrm{YFP}]$ and $\mathrm{C}_{\mathrm{t}}-[\mathrm{YFP}]$ constructs were used as negative controls, fluorescence was observed both at early (Figure 7G) and late (Figures $7 \mathrm{H}-\mathrm{I}$ ) stages post-agroinfection. However, in both cases the fluorescence distribution was completely different to that observed when the p7A was present, since neither Golgi-stacks (compare Figures 7A vs 7G) nor punctuate granules at the plasma membrane (compare Figures 7B-C vs 7H-I) were observed. Taken together the GFPp7A localization, subcellular fractionation and BiFC experiments strongly indicate that p7A is autonomously targeted to Golgi and PD in absence of any other viral factor. In this scenario, since p7A is a soluble protein and does not require any other viral protein, its localization in these membranous organelles could be lead by host factors.
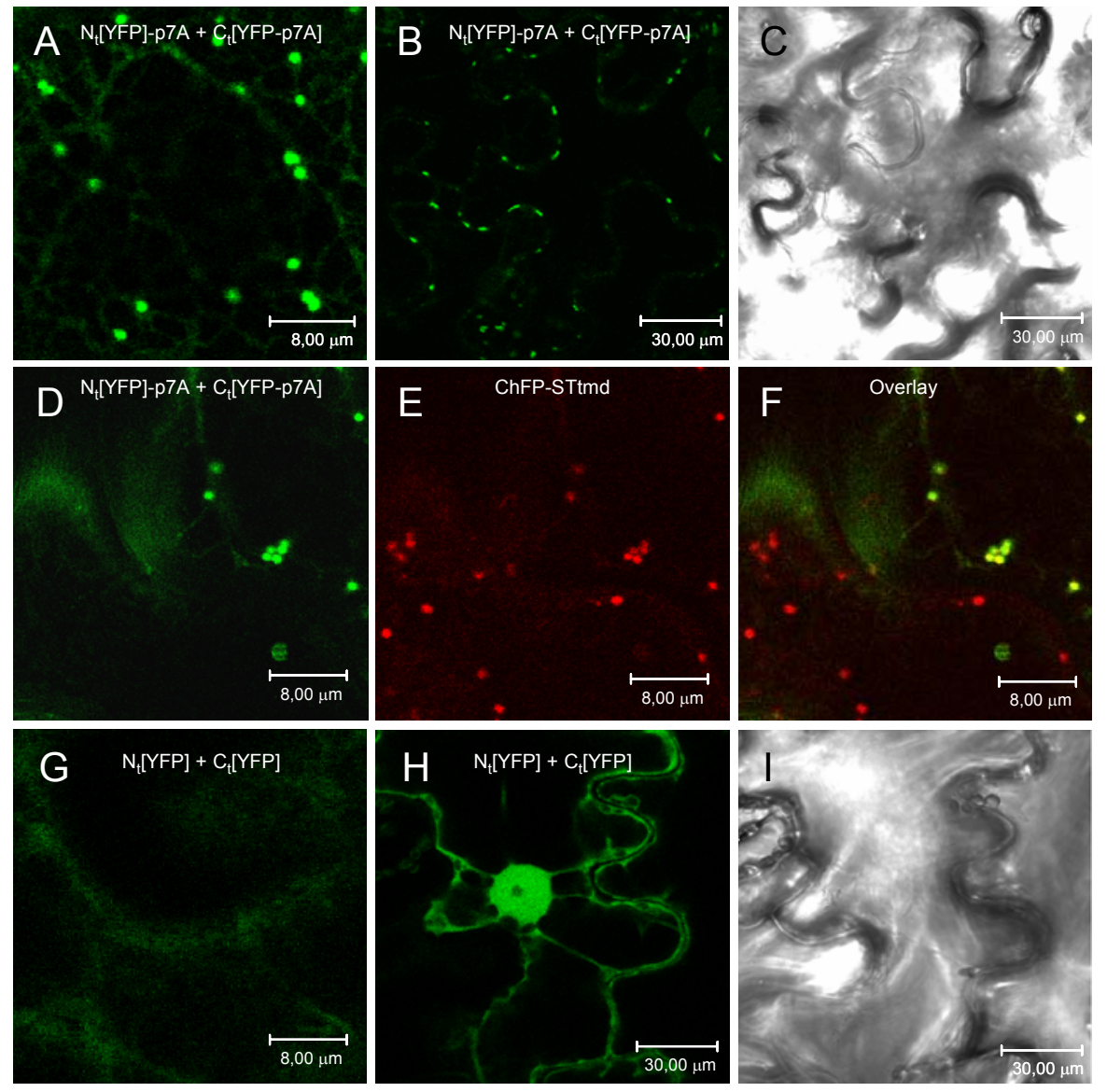

Figure 7. Subcellular localization of GFP-p7A in the absence of viral factors by bimolecular complementation fluorescence assay in $N$. benthamina leaves. A-C) Fluorescence distribution resulting from co-expression of $\mathrm{N}_{t}$-[YFP]p7A and $C_{t}-[Y F P]-p 7 A$ in motile granules (panel $A$ ) and cellular boundary (panel B). A image taken under white light of the panel B scan is displayed in panel C. D-F) Coexpression of $\mathrm{N}_{\mathrm{t}}-[\mathrm{YFP}]-\mathrm{p} 7 \mathrm{~A}$, and $\mathrm{C}_{\mathrm{t}}$ [YFP]-p7A (panel D) together STtmd-ChFP (panel E) recombinant proteins showing colocalization of both fluorescent signals (panel F). G-H) Images taken with panels $A$ and $B$ identical parameters showing the fluorescence distribution that resulted from $\mathrm{N}_{t^{-}}[\mathrm{YFP}]$ and $\mathrm{C}_{t^{-}}$ [YFP] fragments co-expression and the corresponding white light image of the panel $\mathrm{H}$ scan (panel $\mathrm{I}$ ). 


\section{DISCUSSION}

In this work, we focused on the requirements of the RNA binding properties of the DGBp1 in the MNSV movement and its subcellular localization in order to go further in the knowledge of the route this virus utilizes for intracellular trafficking. Previous work demonstrated that the MNSV DGB products (p7A and p7B) operating in trans are sufficient to move viral RNAs among neighbouring cells, indicating that cell-to-cell movement of MNSV should take place as ribonucleoprotein complexes (Genoves et al., 2006). Unlike CarMV DGBp1 (p7), which possesses a precise well-characterized RNA binding domain (RBD) localized at the $\alpha$-helical structured central region of the protein (Marcos et al., 1999; Vilar et al., 2001; Vilar et al., 2005), both the amino and carboxyl terminal regions of the MNSV p7A molecule were shown to be involved in the in vitro RNA-binding, in spite of being less important than the central region (Navarro et al., 2006). In the other hand, the essential role of the positively charged amino acids lateral chains in the RNA binding process has been described for different viral genera (Herranz et al., 2005; Morozov and Solovyev, 2003) including carmoviruses (Vilar et al., 2001; Wobbe et al., 1998). However, experimental data supporting those observations were not provided. Thus, the nature of the p7A-RNA interaction and their relevance in MNSV cell-to-cell movement was explored.

Two RNA binding themes commonly observed in RNA-protein interactions can be found among the conserved structural elements of p7A: (i) a sequence rich in arginine and lysine residues, mainly comprising both the $\mathrm{Nt}$ and central domain, which can be induced to fold as a $\alpha$-helical conformation and (ii) the aromatic residues positioned at the end of the $\beta$-sheet-folded Ct region that could be also involved in unstacked RNA bases binding (Drapper, 1999; Jones et al., 2001). Our results revealed that cell-to-cell movement was essentially not permissive to any change affecting either the removal of positively charged residues or the destabilizing of the secondary structure of the p7A central region whereas $\mathrm{Nt}$ and $\mathrm{Ct}$ regions admitted reduction in the number of positive charges before the movement was completely abolished. Moreover, the correlation of cell-to-cell movement extension with the p7A RNA binding activity was corroborated by EMSA. The major contribution of the central region in this interaction was further demonstrated since the reduction in only one of the positive charges as well as the distortion of the $\alpha$-helix by proline insertion resulted in the total inhibition of the in vitro RNA binding ability of p7A, whereas, the interaction seems to be unaltered when two positive charges were removed from the $\mathrm{Nt}$ region. These results are similar to those observed for the RNA binding domain (RBD) of the Prunus necrotic ringspot virus (PNRSV) MP (Herranz et al., 2005), for which RNA binding properties were shown to be essential for cell-to-cell movement. In the other hand, a different situation was observed when the aromatic lateral chains of the conserved residues located at the $\mathrm{Ct}$ end of p7A were eliminated. In this case, cell-to-cell movement was blocked but RNA binding affinity was not abolished. Impaired cell-to-cell movement in FNF motif p7A mutant could result from the hindering of essential interaction with 
either viral or host proteins, since, the aromatic residues could act as anchors in the binding interface of identical or different interacting proteins (Rajamani et al., 2004) and conserved polar and aromatic residues have been shown to be highly likely peptide binding sites (Ma et al., 2003).

Furthermore, our results demonstrated that the MNSV p7A is associated to the Golgi stack system and to the cell peripheral PD in the absence of the MNSV p7B, the membraneassociated partner essential for MNSV cell-to-cell movement, and any other viral factor. Interestingly, as far as we know, no previous association to Golgi stacks has been described for viral movement proteins. Moreover, it is generally accepted that intra e intercellular movement of plant viruses occurs through cellular machinery of macromolecular transport that the virus hijacks for its delivery to and through PD. According to this, it has been established the involvement of the cortical ER and the actin cytoskeleton for targeting TMV MP to PD, the secretory vesicles for tubule-forming viruses and the actin-ER-driven and the endocitic pathways for the TGB MPs (see Ritzenthaler and Hofman, 2007 and Waigmann et al., 2007 for review). Nevertheless, the association to the Golgi apparatus has never been demonstrated before in any of these mechanisms.

In the other hand, it has been reported that RNA-binding MPs from multi-component transport systems such as the triple gene block of proteins from rod-shaped viruses (the triple gene block protein 1; TGBp1) and $30 \mathrm{~K}$ superfamily members are localized in the plasmodesmata of infected tissue. However, the TGBp1 generated from either transient or transgene-expression was uniformly distributed inside the cell and localization in PD of Hordeilike TGBp1 is determined by the viral membrane-associated movement proteins referred to as TGBp2 and TGBp3 (Erhardt et al., 2000; Erhardt et al., 1999; Lawrence and Jackson, 2001; Zamyatnin et al., 2004). For MNSV, we have observed that the RNA-binding protein, p7A, does not require either the counterpart membrane protein, $\mathrm{p} 7 \mathrm{~B}$, or any other viral factor for its association to PDs or GA stacks. However, since p7A is a soluble protein, this association must be mediated by a host factor from the GA unidentified yet. Supporting this idea, transmembrane proteins from the Golgi complex have been described to interact with animal viruses although their function are still unknown (Compton and Behrend, 2006).Indeed, the results obtained by GFPp7A resemble very much those observed for the GRIP domain proteins, a class of golgins that have been described in yeast, animals and also in plants (Latijnhouwers et al., 2005; Stefano et al., 2006; Yoshino et al., 2003). The GRIP-domain proteins bind to a soluble Arf-like protein 1 (Arl1p) that is also located at the trans-Golgi by a signalling cascade involving a Golgi localized integral membrane (Liu et al., 2006). In this scenario, it is feasible that the subcellular localization of p7A could be also mediated by the interaction with a host protein which, in turn, could be located at the cytosolic surface of the Golgi stack membranes. Evidence for the TCV DGBp1 (p8) interaction with an A. thaliana protein (Atp8, from $\underline{A}$. thaliana-p8) which contain two putative transmembrane domains and two RGD amino acid sequences recognized by integrins has been obtained (Lin and Heaton, 2001). However, p8-GFP was confined to the cell nucleus 
and the role of this interaction in cell-to-cell movement remains unclear. Further studies are necessary to identify the host factor recruiting p7A to the Golgi stacks and the corresponding structural elements involved in this interaction.

In this study, we have presented experimental data showing that p7A RNA-binding activity is directly associated with MNSV cell-to-cell movement, suggesting that this protein is most likely the viral factor that recognizes the viral genome to initiate the intra and intercellular transport of the movement-competent complexes. Moreover, considering that the Golgi apparatus is an intermediate compartment within the secretory pathway throughout which numerous secreted proteins are continuously trafficking, the subcellular localization of the tagged p7A in the membrane surface of Golgi stacks and later at the PD suggested that this MP could follows this pathway for its intracellular trafficking.

\section{ACKNOWLEDGEMENTS}

We thank L. Corachán and L. Latorre for their technical assistance. This work was supported by Grants BIO05-7331 and GV04B-183 from the grating agency DGICYT and Generalitat Valenciana, respectively. J.A. Navarro and A. Genovés are recipients of an I3P contract and a PhD fellowship from the Consejo Superior de Investigaciones Cientificas and the Spanish Ministerio de Educacion y Ciencia, respectively. The pCBSTtmdCherry Golgi marker and pRT-YN-ER and pRT-YC-ER were kindly provided by Dr V.V. Dolja and Dr J. P. T. Valkonen, respectively. The Isolate MNSV-264 was kindly supplied by $\mathrm{Dr}$ M. A. Aranda. 


\section{REFERENCES}

Akgoz, M., Nguyen, Q. N., Talmadge, A. E., Drainville, K. E. and Wobbe, K.K. (2001) Mutational analysis of Turnip crinkle virus movement protein p8. Mol. Plant Pathol. 2, 37-48

Boevink, P. and Oparka, K. J. (2005) Virus-host interactions during movement processes. Plant Physiol. 138, 1815-1821.

Boyko, V., Hu, Q., Seemanpillai, M., Ashby, J. and Heinlein, M. (2007). Validation of microtubule-associated Tobacco mosaic virus RNA movement and involvement of microtubule-aligned particle trafficking. Plant J . 51:589-603.

Citovsky, V., Lee, I.-Y., Vyas, S., Glick, E., Chen, M.-H., Vainstein, A., Gafni, Y., Gelvin, S. B. and Tzfira, T. (2006) Subcellular localization of interacting proteins by bimolecular fluorescence complementation in planta. J. Mol. Biol. 362, 1120-1131.

Cohen, Y., Gisel, A. and Zambryski, P.C. (2000) Cell-to-cell and systemic movement of recombinant green fluorescent protein-tagged Turnip crinkle virus. Virology, 273, 258266.

Compton, S. L. and Behrend, E. N. (2006). PRAF1: a Golgi complex transmembrane protein that interacts with viruses Biochem. Cell Biol. 84, 940-948.

Diaz, J. A., Nieto, C., Moriones, E., Truniger, V. and Aranda, M.A. (2004) Molecular characterization of a Melon necrotic spot virus strain that overcomes the resistance in melon and nonhost plants. Mol. Plant Microbe Interact. 17, 668-675.

Drapper D. E. (1999) Themes in RNA-protein recognition. J. Mol. Biol. 293, 255-270.

Erhardt, M., Morant, M., Ritzenthaler, C., Stussi-Garaud, C., Guilley, H., Richards, k., Jonard, G., Bouzoubaa, S. and Gilmer, D. (2000) P42 movement protein of Beet necrotic yellow vein virus is targeted by the movement proteins P13 and P15 to punctuate bodies associated with plasmodesmata. Mol. Plant Microbe Interact. 13, 520528.

Erhardt, M., Stussi-Garaud, C., Guilley, H., Richards, K. E., Jonards, G. and Bouzoubaa, S. (1999) The first triple gene block protein of Peanut clump virus localizes to the plasmodesmata during virus infection. Virology, 264, 220-229.

Genoves, A., Navarro, J. A. and Pallas, V. (2006) Functional analysis of the five Melon necrotic spot virus genome-encoded proteins. J. Gen. Virol. 87, 2371-2380.

Gosalvez, B., Navarro, J. A., Lorca, A., Botella, F., Sanchez-Pina, M. A. and Pallas, V. (2003) Detection of Melon necrotic spot virus in water samples and melon plants by molecular methods. J. Virol. Methods. 113, 87-93.

Haup, S., Cowan, G. H., Ziegler, A., Roberts, A. G., Oparka, K. J. and Torrance, L. (2005) Two plant-viral movement proteins traffic in the endocytic recycling pathway. Plant Cell, 17, 164-181. 
Herranz, M. C. and Pallas V. (2004) RNA-binding properties and mapping of the RNA-binding domain from the movement protein of Prunus necrotic ringspot virus. J. Gen. Virol. 85, 761-768.

Herranz, M. C., Sanchez-Navarro, J. A., Sauri, A., Mingarro, I. and Pallas, V. (2005) Mutational analysis of the RNA-binding domain of the Prunus necrotic ringspot virus (PNRSV) movement protein reveals its requirement for cell-to-cell movement. Virology, 339, 31-41.

Hull, R. (2002) Virus movement through the plant and effects on plant metabolism. In Matthews' plant virology, 4th edn, pp 373-436. Edited by Academic Press, San Diego.

Jones, S., Daley, D. T. A., Luscombe, N. M., Berman, H. M. and Thornton, J. M. (2001) Protein-RNA interactions: a structural analysis. Nucleic Acids Res. 29, 943-954.

Kalinina, N. O., Rakitina, D. A., Yelina, N. E., Zamyatnin, A. A., Stroganova, T. A., Klinov, D. V., Prokhorov, V. V., Ustinova, S. V., Chernov, B. K., Schiemann, J., Solovyev, A. G. and Morozov, S. Y. (2001) RNA-binding properties of the $63 \mathrm{kDa}$ protein by the triple gene block of Poa semilatent hordeivirus. J. Gen. Virol. 82, 2569-2578.

Knoester M., van Loon, L. C., van den Heuvel, J., Hennig, J., Bol, J. F. and Linthorst, H. J. M. (1998) Ethylene-insensitive tobacco lacks nonhost resistance against soil-borne fungi. Proc. Natl. Acad. Sci. U S A, 95, 1933-1937.

Laporte, C., Vetter, G., Loudes, A.M., Robinson, D.G., Hillmer, S., Stussi-Garaud, C. and Ritzenthaler, C. (2003) Involvement of the secretory pathway and the cytoskeleton in intracellular targeting and tubule assembly of Grapevine fanleaf virus movement protein in tobacco BY-2 cells. Plant Cell. 15, 2058-1075.

Latijnhouwers, M., Hawes, C., Carvalho, C., Oparka, K., Gillingham, A. K. and Boevink, P. (2005) An Arabidopsis GRIP domain protein locates to the trans-Golgi and binds small GTPase ARL1. Plant J. 44, 459-470.

Lawrence, M. and Jackson, A. O. (2001) Interactions of the TGB1 protein during cell-to-cell movement of barley stripe mosaic virus. J. Virol. 75, 8712-8723.

Lin, B. and Heaton, L. A. (2001) An Arabidpsis thaliana protein interacts with a movement protein of Turnip crinkle virus in yeast cells and in vitro. J. Gen. Virol. 82, 1245-1251.

Liu, Y., Lee, S. and Lee, F. S. (2006) Arl1p is involved in transport of the GPI-anchored protein Gas1p from the late Golgi to the plasma membrane. J. Cell Sci. 119, 3845-3855.

Lucas, W. J. (2006) Plant viral movement proteins: Agents for cell-to-cell trafficking of viral genomes. Virology. 344, 169-184.

Ma, B., Elkayam, T., Wolfson, H. and Nussinov, R. (2003) Protein-protein interactions: structurally conserved residues distinguish between binding sites and exposed protein surfaces. Proc. Natl. Acad. Sci. U S A, 100, 5772-5777.

Marcos, J. F., Vilar, M., Perez-Paya, E. and Pallas, V. (1999) In vivo detection, RNA-binding properties and characterization of the RNA-binding domain of the p7 putative movement protein from Carnation mottle carmovirus (CarMV). Virology, 255, 354-365. 
Martínez-Gil L., Saurí A., Vilar M., Pallás V. and Mingarro I. (2007) Membrane insertion and topology of the p7B movement protein of Melon Necrotic Spot Virus (MNSV). Virology, 367:348-357.

Morozov, S. Y. and Solovyev, A. G. (2003) Triple gene block: modular design of a multifunctional machine for plant virus movement. J. Gen. Virol. 84, 1351-1366.

Navarro, J. A., Genoves, A., Climent, J., Sauri, A., Martinez-Gil, L., Mingarro, I. and Pallas, V. (2006) RNA-binding properties and membrane insertion of Melon necrotic spot virus (MNSV) double gene block movement proteins. Virology, 356, 57-67.

Nelson, R. S. and Citovsky, V. (2005) Plant viruses. Invaders of cells and pirates of cellular pathways. Plant Physiol. 138, 1809-1814.

Osborne, J. C. and Elliot, R. M. (2000) RNA binding properties of Bunyamwera virus nucleocapsid protein and selective binding to an element in the $5^{\prime}$ terminus of the negative-sense S segment. J. Virol. 74, 9946-9952.

Pallás, V., Más, P. and Sánchez-Navarro, J.A. (1998) Detection of plant RNA viruses by nonisotopic dot-blot hybridisation. In: G. Foster and S. Taylor (Eds), Plant Virus Protocols: From Virus Isolation to Transgenic Resistance, Humana Press, Totowa, New Jersey, pp. 461-468.

Peremyslov, V. V., Pan, Y. W. and Dolja, V. V. (2004) Movement protein of a closterovirus is a type III integral transmembrane protein localized to the endoplasmic reticulum. J. Virol. 78, 3704-3709.

Rajamani, D., Thiel, S., Bajad, S. and Camacho, C. J. (2004) Anchor residues in proteinprotein interactions. Proc. Natl. Acad. Sci. U S A, 101, 11287-11292.

Riviere, C. J. and Rochon, D. M. (1990) Nucleotide-sequence and genomic organization of Melon necrotic spot virus. J. Gen. Virol. 71, 1887-1896.

Ritzenthaler, C. and Hofman, C. (2007). Tubule guide movement of plant viruses. In: Viral Transport in Plants (Waigmann, E. and Heinlein, M., eds.). Springer-Verlag Berlin Heidelberg, pp. 63-83.

Saint-Jore-Dupas, C., Gomord V. and Paris, N. (2004) Protein localization in the plant Golgi apparatus and the trans-Golgi network. Cell. Mol. Life Sci. 61, 159-171.

Sánchez-Navarro, J. A., Herranz, M. C. and Pallas, V. (2006) Cell-to-cell movement of Alfalfa mosaic virus can be mediated by the movement proteins of Ilar-, bromo-, cucumo-, tobamo- and comoviruses, and does not require virion formation. Virology, 346, 66-73.

Sauri A., Saksena S., Salgado J., Johnson A.E. and Mingarro I. (2005) Double-spanning plant viral movement protein integration into the endoplasmic reticulum membrane is signal recognition particle-dependent, translocon-mediated, and concerted. J Biol Chem. 280, 25907-25912.

Scholthof, H. B. (2005) Plant virus transport: motions of functional equivalence. Trends Plant. Sci. 10, 376-382. 
Stefano, G., Renna, L., Hanton, S. L., Chatre, L., Haas, T. A. and Brandizzi, F. (2006) ARL1 plays a role in the binding of the GRIP domain of a peripheral matrix protein to the Golgi apparatus in plant cells. Plant Mol. Biol. 61, 431-449.

Vilar, M., Esteve, V., Pallas, V., Marcos, J. F. and Perez-Paya, E. (2001) Structural properties of carnation mottle virus p7 movement protein and its RNA-binding domain. J. Biol. Chem. 276, 18122-18129.

Vilar, M., Sauri, A., Marcos, J. F., Mingarro, I. and Perez-Paya, E. (2005) Transient structural ordering of the RNA-binding domain of Carnation mottle virus p7 movement protein modulates nucleic acid binding. Chembiochem, 6, 1391-1396.

Vilar, M., Sauri, A., Monne, M., Marcos, J. F., von Heijne, G., Perez-Paya, E. and Mingarro, I. (2002) Insertion and topology of a plant viral movement protein in the endoplasmic reticulum membrane. J. Biol. Chem. 277, 23447-23452.

Waigmann, E., Curin, M. and Heinlein, M. (2007). Tobacco mosaic virus-a model for macromolecular cell-to-cell spread. In: Viral Transport in Plants (Waigmann, E. and Heinlein, M., eds.). Springer-Verlag Berlin Heidelberg, pp. 29-62.

Waigmann, E., Ueki, S., Trutnyeva, K. and Citovsky, V. (2004) The ins and outs of nondestructive cell-to-cell and systemic movement of plant viruses. Crit. Rev.Plant Sci. 23, 195-250.

Waigmann, E., Lucas, W.J., Citovsky, V. and Zambryski, P. (1994). Direct functional assay for tobacco mosaic virus cell-to-cell movement protein and identification of a domain involved in increasing plasmodesmal permeability. Proc Natl Acad Sci U S A. 91,14331437.

Walter M, Chaban C, Schütze K, Batistic O, Weckermann K, Näke C, Blazevic D, Grefen C, Schumacher K, Oecking C, Harter K, and Kudla J. (2004) Visualization of protein interactions in living plant cells using bimolecular fluorescence complementation. Plant J. 40, 428-38.

Wee, E. G.-T., Sherrier, d. J., Prime, T. A. and Dupree, P. (1998) Targeting of active Sialyltransferase to the plant Golgi apparatus. Plant Cell, 10, 1759-1768.

Wobbe, K. K., Akgoz, M., Dempsey, D. A. and Klessig, D. F. (1998) A single amino acid change in Turnip crinkle virus movement protein p8 affects RNA binding and virulence on Arabidopsis thaliana. J. Virol. 72, 6247-6250.

Wright, K. M., Wood, N. T., Roberts, A. G., Chapman, S., Boevink, P., MacKenzie, K. M. and Oparka, K. J. (2007) Targeting of TMV movement protein to plasmodesmata requires the actin/ER network: evidence from FRAP. Traffic, 8, 21-31.

Yoshino, A., Bieler, B. M., Harper, D. C., Cowan, D. A., Sutterwala, S., Gay, D. M., Cole, N. B., McCaffery, J. M. and Marks, M. S. (2003) A role for GRIP domain proteins and/or their ligands in structure and function of the trans Golgi network. J. Cell Sci. 116, 44414454. 
Zamyatnin Jr. A. A., Solovyev, A. G., Bozhkov, P. V., Valkonen, J. P. T., Morozov, S. Y. and Savenkov, E. I. (2006) Assessment of the integral membrane protein topology in living cells. Plant J. 46, 145-154.

Zamyatnin, Jr. A. A., Solovyev, A. G., Savenkov, E. I., Germundsson, A., Sandgren, M., Valkonen, J. P. T. and Morozov S. Y. (2004) Transient coexpression of individual genes encoded by the Triple Gene Block of potato mop-top virus reveals requirements for TGBp1 trafficking. MPMI. 17, 921-930. 


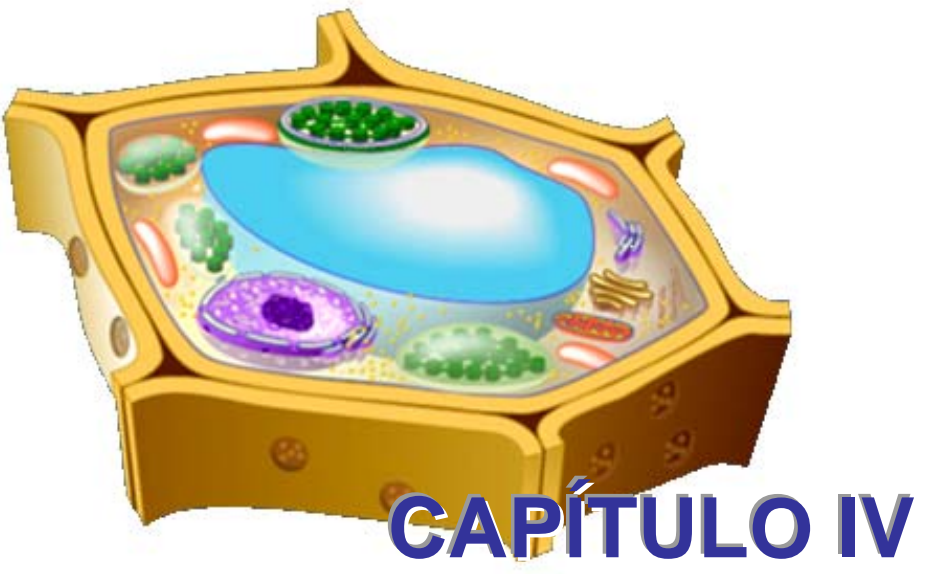




\title{
Golgi-mediated traffic to plasmodesmata of a plant membrane- associated viral protein
}

\author{
A. Genovés ${ }^{1}$, J. A. Navarro ${ }^{1}$, A. I. Prokhnevsky ${ }^{2}$, V. V. Dolja ${ }^{2}$ and V. Pallás ${ }^{1}$ \\ ${ }^{1}$ Instituto de Biología Molecular y Celular de Plantas, Universidad Politécnica de Valencia- \\ CSIC, Avenida de los Naranjos s/n, 46022 Valencia, Spain. \\ 2. Department of Botany and Plant Pathology. Oregon State University, Corvallis, OR 97331.
}

\begin{abstract}
Plant viruses hijack endogenous cellular routes to move from the initial replication sites to the plasma membrane which is traversed through plasmodesmata (PD). Here, we study the intracellular route of a membrane-associate viral protein, MNSV 7B, involved in the cell-to-cell movement of Melon necrotic spot virus. Thus, in transient expression assays of fluorescent tagged p7B, the MP was initially positioned at the polygonal network of the cortical ER and the extern nuclear envelope but later, the protein transited to both motile bodies that actively tracked the actin microfilaments and punctuate structures into plasma membrane. Coexpression with organelle markers revealed that these structures corresponded to the Golgi apparatus (GA) stacks and plasmodesmata (PD), respectively. Additionally, the fact that the secretory pathway inhibitor brefeldin A (BFA) fully retained the p7B into ER by stopping the MP traffic to GA bodies and PD, strongly suggested that the delivering to this later destination is mediated by a GAdependent pathway, where the PD is most likely the functional final target. On the other hand, the disruption of some topological and membrane insertion determinants found among the conserved structural elements of this MP by means of site-directed mutagenesis into a quimeric GFP/MNSV vector revealed a strong correlation between cell-to-cell movement and ER-to-Golgi export, also supported by the restriction of local spread of the infection when the secretory pathway was disrupted in the presence of BFA. Therefore, our results represent the first direct evidence about the existence of a Golgi-mediated traffic of a plant viral protein to PD that was essential for viral cell-to-cell movement.
\end{abstract}




\section{INTRODUCTION}

In order to move from cell-to-cell plant viruses overcome the cell wall barrier by traversing it through the specialized pores called plasmodesmata (PD) (Beachy and Heinlein, 2000). These narrow channels are symplastic connections that allow the transport of solutes, macromolecules and signaling factors among cells either controlling the coordination of the plant development or the responses to pathogen invasion (Zambrisky and Crawford, 2000). The plasmodesmal pore is occupied by a number of associated proteins and the desmotubule, an actine-entwined membrane cylinder connecting the endoplasmic reticulum (ER) from adjoining cells (Overall, 1999). It is now well established that the viral traffic through PD occurs only when it is either mediated by a single or, in the case of multi-component movement systems, by more than one non-structural virus-encoded factor termed movement proteins (MPs) (Waigmann et al., 2004; Lucas, 2006). To accomplish this task, the MPs make use of mainly two different strategies; either generate an increasing of the size exclusion limit (SEL) of the PD channel to mediate cell-to-cell transport of a complex of viral RNA and MP or as viral replication complex (Hawakami et al., 2004) or instead, an embedded tubular arrangement which highly modify the native structure and through which virion are transported to the neighboring cell. A third intermediate alternative has been recently proposed by which MP assembles into tubules to promote the movement of CP/RNA ribonucleoprotein complex rather than entire virus particles (Sánchez-Navarro et al., 2006). In addition to this functional quality, other two general features consisting on the capacities of RNA/DNA binding and self-delivering to PD are also found among all characterized MPs (Waigmann et al., 2004; Lucas, 2006). In view of this data, it is obvious that these multifunctional factors are also involved in viral genome translocation from the subcelular compartment where its replication take place to the cellular periphery (intracellular transport) and thus, after PD traversing, viruses progressively colonize the neighboring cells (intercellular transport or cell-to-cell movement). According to the viral movement system considered, a variety of strategies for intracellular transport have been described; but in any case, all of them were heavily dependent on endogenous host transport machinery (Boevink and Oparka, 2005; Nelson and Citovsky, 2005). The internal organization of plant cells includes an intricate endomembrane system defining highly dynamic subcellular compartments (i.e. endoplasmic reticulum, ER; Golgi apparatus, GA; endosomes, prevacuoles and a great variety of vacuoles) that is functionally assisted by a network of actin/myosin-motors microfilaments and microtubules (cytoskeleton) (Jürgens, 2004). In this scenario, the GA plays a central role in the correct delivering of a variety of cargo molecules to the pathway toward its appropriate final destination such as cell wall, plasma membrane, external surface, storage and lytic vacuoles (Matheson et al., 2006; Moreau et al, 2007; Robinson et al., 2007). Additionally, GA has been described as an alternative route to the chloroplasts, the mitochondria and peroxisomes (Matheson et al., 2006). Moreover, the plant cell GA shares unique structural 
features that make it different from both mammalian and yeast GA; it is divided into a variable number of small cisternae stacks functionally independents which shows a dynamic translocation along the cortical ER/actin microfilaments network most likely driven by myosin motors (Boevink et al, 1998; Hawes and Satiat-Jeunemaitre, 2005; Robinson et al., 2007).

How plant viruses take advantage of this intracellular highways network seems to be related to the structural and functional characteristics of the factors associated to their movement machinery. Tobacco mosaic virus (TMV) cell-to-cell movement is driven by an extensively characterized single protein of $30 \mathrm{kDa}$ which shares structural similarities with a large number of plant virus MPs (the $30 \mathrm{~K}$ superfamily) (Melcher, 2000). Moreover, PD gating by TMV MP is most likely accomplished without significantly disturb the original structure and therefore, maintaining unbroken the intercellular connection through the desmotubule ER (Wolf et al., 1989). In this situation, it has been demonstrated that TMV MP may arrive to desmotubule and consequently to PD by tracking itself to the actin/myosin directed flow of proteins along the ER membrane (Wright et al., 2007). Additionally, TMV movement has been related with the MP association to the microtubules (Ashby et al., 2006; Ferralli et al., 2006). Some experimental evidences indicated that this later microtubule-interaction is most likely involved in a proteasome dependent MP degradation pathway rather than in PD targeting (Reichel and Beachy, 2000) although controversial data are still being reported (Boyko et al., 2007; Curin et al, 2007). It is feasible that the TMV MP would be delivered to PD by following two alternative routes as in the case of the Grapevine fanleaf virus (GFLV). The MP of this tubule forming virus was not associated to ER membranes; therefore the ER would not serve as a direct route to PD since during the tubule formation the PD desmotubule is lost. Despite this inconvenience, GFLV MP can arrive to its final destination by using the plant secretory pathway but either travelling along microtubules in normal cells or along actin microfilaments when microtubules are lacking (Laporte et al., 2003). In contrast to that, PD targeting of another tubule-forming MP from Cowpea mosaic virus (CPMV) was not affected by disruption of either the secretory pathway or cytoskeleton (Pouwels et al., 2002) indicating that mechanistic differences would exist among the strategies used by related tubule-forming virus (reviewed by Ritzenthaler and Hofmann, 2007). On the other hand, in two groups of positive-strand RNA viruses (potex-like and hordeilike viruses), the movement function is provided by the proteins encoded by the so-called triple gene block (TGB) including an RNA binding protein with helicase activity (TGBp1) and two putative small membrane-associated proteins (TGBp2 and TGBp3). All three proteins move from ER to the cellular periphery generating ER-derived vesicles which also travel along actin/myosin microfilaments and it is also known that later, the membrane-associated MPs can be recycled making use of the endocityc pathway (Haupt et al, 2005; Ju et al, 2007; Morozov and Solovyev, 2003).

With the purpose of going further in the knowledge of the different routes plant viruses hijack to reach the PDs we use one of the most simple multi-component transport system 
identified to date such as those of the Carmovirus genus, which is extremely reduced in the case of Melon necrotic spot virus, MNSV (Hibi and Furuki, 1985). The MNSV has a singlestranded RNA genome of $4.3 \mathrm{~kb}$ long which code for five functionally characterized proteins: p29 and his read-through protein p89, two proteins functionally involved in genome replication which are directly translated from the genomic-length RNA (gRNA); p7A and p7B, two small movement proteins, (corresponding to the DGB, and then also referred as DGBp1 and DGBp2, respectively) which are translated from the $1.9 \mathrm{~Kb}$ subgenomic RNA (sgRNA1) (Navarro et al., 2006), and finally, p42, the coat protein which is translated from $1.6 \mathrm{~Kb}$ subgenomic RNA (sgRNA2) (Genoves et al., 2006; Riviere \& Rochon, 1990). Considering both MPS, biochemical assays have demonstrated that $\mathrm{p7A}$ as well as others homologous DGBp1 are positively charged residues rich proteins that are able to bind single stranded RNA (ssRNA) (Marcos et al., 1999; Vilar et al., 2001; Vilar et al., 2005, Navarro et al, 2006). On the other hand, p7B was confirmed as an integral membrane protein that anchors in the reticulum endoplasmic trough a single-spanning transmembrane domain (Navarro et al, 2006; Martinez-Gil et al., 2007). Also taking into account that the coat protein was dispensable for MNSV cell-to-cell movement (Genoves et al, 2006), it is reasonable to speculate that local spread of MNSV occurs by means of a hypothetical ribonucleoprotein complex (genome-p7A) that will be assisted by the ERinteracting p7B to complete its intracellular movement.

Therefore, in this investigation we have addressed a detailed study on p7B subcellular localization by using a transient expression system involving fusions between this protein and fluorescent reporters. This MP was initially localized at the ER but later trafficked to Golgi stacks and PD. Moreover, the contribution of common membrane-insertion and topology determinants found into $\mathrm{p7B}$ as well as the Cys-covalent dimmer formation was evaluated either on local spread of the infection or p7B Golgi-mediated targeting to PD. To address this issue, a sitedirect mutagenesis assay including amino acid replacements either into a GFP-MNSV quimeric construct or into a binary vector expressing a fluorescent tagged p7B was performed. From results obtained we concluded that both p7B localization on Golgi stacks and the presence of a functional Golgi-mediated secretory pathway are essential for MNSV cell-to-cell movement.

\section{MATERIALS AND METHODS}

\section{Construction of binary vectors for fluorescent-tagged-p7B recombinant proteins expression and p7B membrane topology assessment.}

The p7B ORF was amplified from pMNSV(AI) vector containing the full-length sequence of MNSV-Al genome (accession number DQ339157, Genoves et al., 2006; Gosalvez et al., 2003). After that, the corresponding cDNA was either fused in frame to the $\mathrm{Nt}$ or to the $\mathrm{Ct}$ of the enhanced green fluorescent protein gene (GFP) to generate the p7B-GFP and GFP-p7B 
recombinant proteins, respectively, by using standard molecular cloning procedures (Sambrook et al., 1989). Additionally, the monomeric red fluorescent protein (mRFP) gene was joined to the $\mathrm{Nt}$ of the p7B resulting in the mRFP-p7B fusion protein. All three recombinant sequences (p7BGFP, GFP-p7B and mRFP-p7B) were inserted between the 35S promoter of Cauliflower mosaic virus and the Solanum tuberosum proteinase inhibitor terminator (PoPit) in pMOG800 binary vector (Knoester et al., 1998) to generate pM-7BGFP, pM-GFP7B and pM-RFP7B, respectively.

For p7B membrane topology studies, the cDNAs of both p7B- $\mathrm{N}_{\mathrm{t}}-[\mathrm{YFP}]$ and $\mathrm{p} 7 \mathrm{~B}-\mathrm{C}_{\mathrm{t}}-[\mathrm{YFP}]$ recombinant proteins consisting on an Nt-terminal yellow fluorescent protein (YFP) fragment (residues 1-155, referred to as $\mathrm{N}_{\mathrm{t}}$-[YFP]) and a Ct-terminal YFP fragment (residues 156-238, referred to as $\mathrm{C}_{\mathrm{t}}$-[YFP]) fused to the $\mathrm{Ct}$ of the p7B, respectively, were obtained (Sambrook et al., 1989). These cDNAs were restricted, purified and inserted in the binary vector pMOG800 under the control of the Cauliflower mosaic virus (CaMV) $35 \mathrm{~S}$ promoter and the terminator sequence of the potato proteinase inhibitor II gene (PoPit). Moreover, similar cDNAs containing the $\mathrm{N}_{\mathrm{t}^{-}}$ [YFP] and $\mathrm{C}_{\mathrm{t}}$-[YFP] fused to the $\mathrm{N}$-terminal signal peptide sequence of Arabidopsis thaliana basic chitinase and the C-terminal ER-retention signal HDEL were restricted from $p R T-Y N-E R$ and pRT-YC-ER, respectively and cloned into pMOG800. pRT-YN-ER and pRT-YC-ER were kindly provided by $\mathrm{Dr}$ Jari P. T. Valkonen. The binary vectors either expressing unfused $\mathrm{N}_{\mathrm{t}^{-}}$ [YFP] or $\mathrm{C}_{\mathrm{t}}[\mathrm{YFP}]$ fragments were available in our laboratory (Aparicio et al., 2006).

\section{Fluorescent-tagged-markers of subcellular compartments.}

The fluorescent markers of different cellular organelles used in co-localization assays with fluorescent-tagged-p7B included: the Tobacco mosaic virus movement protein fused to the

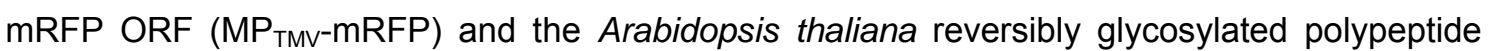
fused to GFP (AtRGP2GFP) both used for plasmodesmata labeling; a cytoskeleton-targeted recombinant protein consisting on the actin-biding domain of the mouse talin fused to the DsRed fluorescent protein (RFPTalin); the rat $\alpha-2,6$-sialyltransferase either fused to the yellow (YFP) or to the cherry (ChFP) fluorescent protein (STtmdYFP and STtmdCherry, respectively) both employed as Golgi-specific fluorescent reporters (Prokhnevsky et al., 2005); a ChFPtagged-peroxisome marker and finally; an endoplasmic reticulum (ER) marker engineered by cloning the ER targeting sequence of calreticulin and the sequence encoding the ER retrieval sequence KDEL at the 5' and 3' end of mRFP, respectively (ER-mRFP). Alternatively, a similar ER marker was constructed but including the YFP instead of the mRFP (ER-YFP).

Additionally, the Beet yellows virus (BYV) p6 ORF fused to the Nt of the GFP (p6GFP) was used as control of a homodimer protein generated by disulfide bridges (Peremyslov et al., 2004).

Transient expression of tagged-p7B recombinant proteins mediated by $A$. tumefaciens infection of $N$. benthamiana plants. 
Transient expression assays on $\mathrm{N}$. benthamiana plants were performed as previously described (Voinnet et al., 2000; Qu et al., 2003). Briefly, all the binary construct described before were introduced into Agrobacterium tumefaciens strain $\mathrm{C} 58 \mathrm{C} 1$ by electroporation (GenePulser Xcell ${ }^{\mathrm{TM}}$ electroporation system, Bio-Rad) and transformed bacteria were grown overnight in a shaking incubator at $28^{\circ} \mathrm{C}$ in Luria-Bertani (LB) medium supplemented with the appropriate antibiotic mixture $(50 \mu \mathrm{g} / \mathrm{ml}$ kanamycin, $100 \mu \mathrm{g} / \mathrm{ml}$ rifampicin, $12,5 \mu \mathrm{g} / \mathrm{ml}$ tetracycline). Besides, the tetracycline was removed in cultures of $A$. tumefaciens either containing the fluorescent subcellular markers or p6-GFP vectors. The cultures were colleted by slow-speed centrifugation and adjusted to the required final $\mathrm{OD}_{600}$ value with $10 \mathrm{mM} \mathrm{MgCl} 2,10$ mM MES pH 5.6 and $150 \mu \mathrm{M}$ acetosyringone and these suspensions were infiltrated into twoweeks-old $N$. benthamiana plants by gentle pressure infiltration into the lower side of the leaves. For both co-localization and topology experiments requiring the simultaneously expression of more than one construct, bacterial strains containing the required vectors were mixed before performing the leaf infiltration with the inoculum of each one adjusted to the required final OD600. Infiltrated plants were kept in grown chambers in $16 \mathrm{~h}$ light at $25^{\circ} \mathrm{C}$ and $8 \mathrm{~h}$ dark at $22^{\circ} \mathrm{C}$.

Site-directed mutagenesis into the pMNSV(Al)- $\triangle \mathrm{cp}$-GFP recombinant vector, in vitro transcription of MNSV RNAs and inoculation of melon plants.

Mutations either affecting the hydrophobic profile or the helix structure of p7B transmembrane domain (TMD) in addition to the charge balance around the TMD were introduced into the p7B ORF from pMNSV(Al)- $\Delta$ cp-GFP making use of the QuickChangeR XLSite Direct Mutagenesis Kit (Stratagene, La Jolla, CA) and the primer pairs enumerated in supplemental table 1. pMNSV(Al)- $\triangle$ cp-GFP was previously obtained by means of the p42 geneto-GFP ORF replacement into the clone pMNSV(Al) containing the full-length genome sequence of MNSV-AI. Recombinant RNAs derived from run-off transcription of pMNSV(Al)- $\Delta c p-G F P$ were successfully used for visualization of the MNSV cell-to-cell movement by fluorescence extension (Genoves et al., 2006). Thus, all pMNSV(Al)- $\Delta$ cp-GFP constructs either carrying the wild-type or each mutant forms of the p7B ORF were linearized by Pstl endonuclease restriction. Non-viral nucleotides located at the 3 '-end were removed by T4 DNA polymerase treatment and in vitro MNSV transcripts were synthesized by T7 RNA polymerase (Roche Diagnostics, Germany). The efficiency of MNSV mutant to move from cell-to-cell was measured by in vivo assays as follows: 6-8-days-old melon plants were mechanically inoculated by rubbing the fully expanded cotyledons with carborumdum and the MNSV uncapped run-off RNAs. Two days before, the cotyledons had been infiltrate with $A$. tumefaciens carrying pMOG42 following the procedure previously described (Genoves et al., 2006). Leica Confocal Lite Sofware was used for the measurement of fluorescent area extension representing viral infection foci. Additionally, some of the modifications introduced into the pMNSV(Al)- $\Delta$ cp-GFP were selected for subcellular localization studies and consequently, also introduced into the p7B ORF of pM-GFP7B 
(QuickChangeR XL-Site Direct Mutagenesis Kit, Stratagene, La Jolla, CA). In the case of cysteine-to-alanine replacement mutant, the pM-7BGFP vector was also modified.

\section{Confocal laser-scanning microscopy and Golgi velocity quantifying}

Plant tissue was observed with both Zeiss LSM 510 META and Leica TCS SL spectral confocal microscopes either using a HC PL FLUOTAR 10x/0.3 or a HCX PL APO 40x/1.25-0.75 oil CS objective. For Leica TCS SL, the GFP or YFP derived fluorescence was monitored by excitation with a 488-nm and 514 argon laser line, respectively, and emission was visualized with a $30 \mathrm{~nm}$-width band-pass window centered at $515 \mathrm{~nm}$. When mRFP and ChFP were used, the excitation was performed by means of a $543 \mathrm{~nm}$ green-neon laser line and fluorescence emission was collected at $610-630 \mathrm{~nm}$.

The velocity at which GFPp7B and STtmdYFP fluorescent particle moved was manually estimated by using Zeiss LSM image browser software. Briefly, ten movie files consisting on a stack of 25 consecutive frames were recorded from different epidermic cells and the distance covered by more than 40 individual fluorescent bodies of each type from the initial to the successive next slices was measured. Considering that the time interval between frames was known, the velocity of each tracked particle was obtained and an average velocity calculated.

\section{Sucrose gradient of microsomal fractionation and immunoblotting.}

Approximately $2 \mathrm{~g}$ of $N$. bentathamiana leaves individually expressing p7B-GFP, GFPp7B, STtmdYFP, ER-YFP by agro-infection were homogenised in lysis buffer containing $20 \mathrm{mM}$ HEPES, pH 6.8; $150 \mathrm{mM}$ potassium acetate; $250 \mathrm{mM}$ mannitol and $1 \mathrm{mM} \mathrm{MgCl}_{2}$. Large cellular debris were removed by gentle centrifugation at $3000 \mathrm{x} \mathrm{g}$ for $10 \mathrm{~min}$ and next, the resulting supernatant was ultracentrifuged at $30,000 \times \mathrm{g}$ for $1 \mathrm{~h}$ to generate the soluble (S30) and the microsomal (P30) fraction. After that, the P30 fraction resuspended in $2 \mathrm{ml}$ of lysis buffer containing $5 \mathrm{mM} \mathrm{MgCl}_{2}$ and later, it was loaded on top of $20 \%$ to $60 \%$ linear sucrose gradients containing lysis buffer with the same $\mathrm{MgCl}_{2}$ concentration. The gradient was centrifuged for $16 \mathrm{~h}$ at $100,000 \mathrm{xg}$ in a Beckman SW40 rotor at $4^{\circ} \mathrm{C}$ and 18 fractions were taken starting from the bottom. Samples from each fraction were analysed were analysed by SDS-PAGE in $12 \%$ poliacrylamide gels and subsequent and transferred to polyvinylidene fluoride membranes (PVDF) (Amersham Biosciences) for immunoblotting with a mouse polyclonal antibody to GFP (Roche Diagnostics, Germany). (Peremyslov et al, 2004).

\section{Brefeldin treatment}

A stock of Brefeldin A (BFA, Invitrogen) was obtained by dissolving the drug in dimethyl sulfoxide (DMSO) solvent at $10 \mathrm{mg} / \mathrm{ml}$ and diluted to $10 \mu \mathrm{g} / \mathrm{ml}$ for their use in all experiments. Two different treatment experiments were performed: for subcellular localization experiments, leaf disc from $N$. benthamiana plant transiently expressing either STtmdYFP or GFPp7B were immersed in BFA solution $(10 \mu \mathrm{g} / \mathrm{mL})$ for $5 \mathrm{~h}$. at $19 \mathrm{~h}$ post infiltration of the $A$. tumefaciens 
cultures; alternatively, for cell-to-cell movement assays, melon cotyledons were infiltrated into the abaxial side with BFA solution $(10 \mu \mathrm{g} / \mathrm{mL})$ at 2,3 and 4 days after inoculation of viral run-off RNAs. Controls were made either by leaf disc immersion in DMSO or direct infiltration into melon cotyledons, respectively.

\section{RESULTS}

p7B Associates with the Endoplasmic Reticulum during Early Virus Infection but Later Transfers to Golgi Apparatus.

The p7B (also referred as MNSV DGBp2) has been functionally characterized as an essential protein for MNSV cell-to-cell movement that operates coordinately with its DGB counterpart designed as p7A (Genoves et al., 2006). The structural properties of p7B revealed the presence of a single-transmembrane domain roughly spanning from the $S_{14}$ to the $L_{32}$ residue that allows the protein insertion into ER-derived microsomal membranes obtained in vitro (Navarro et al., 2006; Martinez-Gil et al., 2007). To visualize the membranous intracellular compartment where this protein is most likely targeted, GFP fluorescent reporter was either fused to the amino $(\mathrm{Nt})$ or carboxyl $(\mathrm{Ct})$ terminus of the viral MP to generate the recombinant proteins GFPp7B or p7BGFP, respectively. Additionally, a different tag consisting on the mRFP was attached to the p7B Nt end. All recombinant proteins were transiently expressed in $N$. benthamiana leaves and later, a portion of each leaf was sliced and analyzed by laser scanning microcopy at different times. Initially, at 24-36 hours post infiltration, the fluorescence was distributed as an elaborate polygonal network most likely representing the endoplasmic reticulum (ER) in all expressing cells independently of the cargo construct (data not shown). However, an intriguing finding was observed at 36-72 hours post infiltration since changes in the fluorescence pattern were different depending on the relative position of the p7B ORF in the recombinant proteins. Fusion proteins with the fluorescent reporter positioned at the $\mathrm{Nt}$ of the p7B (GFPp7B and RFPp7B), revealed numerous bright small and motile punctuate structures into the cytoplasm of the cells (Figures $1 \mathrm{~A}$ and $1 \mathrm{~B}$ ) as the network fluorescence was decreasing to completely fading (see per example, Figures 1G, $1 \mathrm{~J}$ and $1 \mathrm{M}$ ). In contrast to this situation, the fluorescence pattern derived from p7B-GFP was maintained as an intense green labeling of the polygonal system (Figure $1 \mathrm{C}$ ) that was essentially indistinguishable from the red staining of the typical cortical ER network in cells expressing both the p7B-GFP and the ER-mRFP reporter (Figures 1D-F). On the other hand, a careful observation of the movement of the GFP-p7B punctuate structures revealed that they were in close association with the cortical ER also labeled by this protein giving them the appearance of being tracked to the tubules network. Moreover, GFP-p7B bodies were not observed to occur away from the ER network even when the protein was no far labeling the ER as visualized in co-expression with the ER-mRFP marker 
(Figures 1G-I). In this sense, it has been reported that the cortical ER can support the motility of a variety of organelles such as Golgi apparatus and peroxisomes that appears to be dependent of the actin cytoskeleton (Boevink et al., 1998; Muench and Mullen, 2003). Thus, to gain further insights into the dynamics of GFP-p7B bodies, co-expression of GFP-p7B and a cytoskeletontargeted recombinant protein consisting on the actin-biding domain of the mouse talin fused to the DsRed fluorescent protein (RFPTalin) was also performed. The resulting confocal laser scanning showed that GFP-p7B bodies were located along the actin filaments, but they halted their movement in the presence of the actin marker (Figures $1 \mathrm{~J}-\mathrm{L}$ ). This situation is most likely related with the blocking in the myosin-dependent motility that has been reported in Arabidopsis thaliana due to the competition between the over-expressed marker and the endogenous actinbinding proteins (Holweg, 2007). This finding suggested that GFP-p7B bodies are not passively dragged along by a streaming of cytoplasm but that they actively track along the actin cables most likely by means of myosin motor. This situation is extremely similar to that of plant Golgi apparatus, constituted by multiple stacks showing myosin-driven translational movement along actin filaments (Boevink et al., 1998) but also resembles that of plant peroxisomes, consisting on actin-traveling organelles which movement is determined by the class $\mathrm{V}$ myosin motor protein Myo2p (Muench and Mullen, 2003). To differentiate whether the GFP-p7B punctuate organelles either correspond to the Golgi apparatus or to the peroxisomes, we simultaneously expressed the GFP-p7B and an established fluorescent reporter of each one of these organelles. The markers consisted on the cherry fluorescent protein either fused to the trasmembrane domain of the rat $\alpha-2,6$-sialyltransferase (STtmd-ChFP) that is targeted to the trans-citernae of Golgi apparatus or to the type 1 peroxisomal targeting signal of the pumkin hydroxypyruvate reductase. The GFP-p7B fluorescent punctuate pattern was indistinguishable to that generated by the Golgi apparatus marker (Figures $1 \mathrm{M}-\mathrm{O}$ ) whereas no colocalization with the peroxisomes was observed (Figures 1P-R). To provide further evidences about the identification of GFP-p7B labeled bodies as Golgi stacks, the average velocity of both GFP-p7B and STtmd-ChFP labelled particles was quantified by using a multiple-frame averaging facility on the Zeiss LSM image browser software. For this purpose, 10 plots of time-lapse sequences made on different individual epidermal cells were used and more than 40 particles of each construct were tracked. The resulting rate for both particles was practically identical and approximately of $0.9 \mu \mathrm{m} \mathrm{s}^{-1}$ (data not shown). This value is in the range of the previously published Golgi speed lying between $0.76 \mu \mathrm{m} \cdot \mathrm{s}^{-1}$ to $3 \mu \mathrm{m} \mathrm{s}^{-1}$ as calculated in the tobacco leaf epidermis and BY-2 cells (Boevink et al., 1998; Yang et al., 2005). Once the GFP-p7B labeled bodies were identified as Golgi stacks, further investigation about the situation involving the ERresident p7B-GFP was performed. Thus, coexpression of p7B-GFP and STtmd-ChFP corroborated that the former was entirely retained in ER since no colocalization of the corresponding green and red signals was imaged in any sample when they were taken at late post infiltration stages (Figures $1 \mathrm{~S}-\mathrm{U}$ ). 

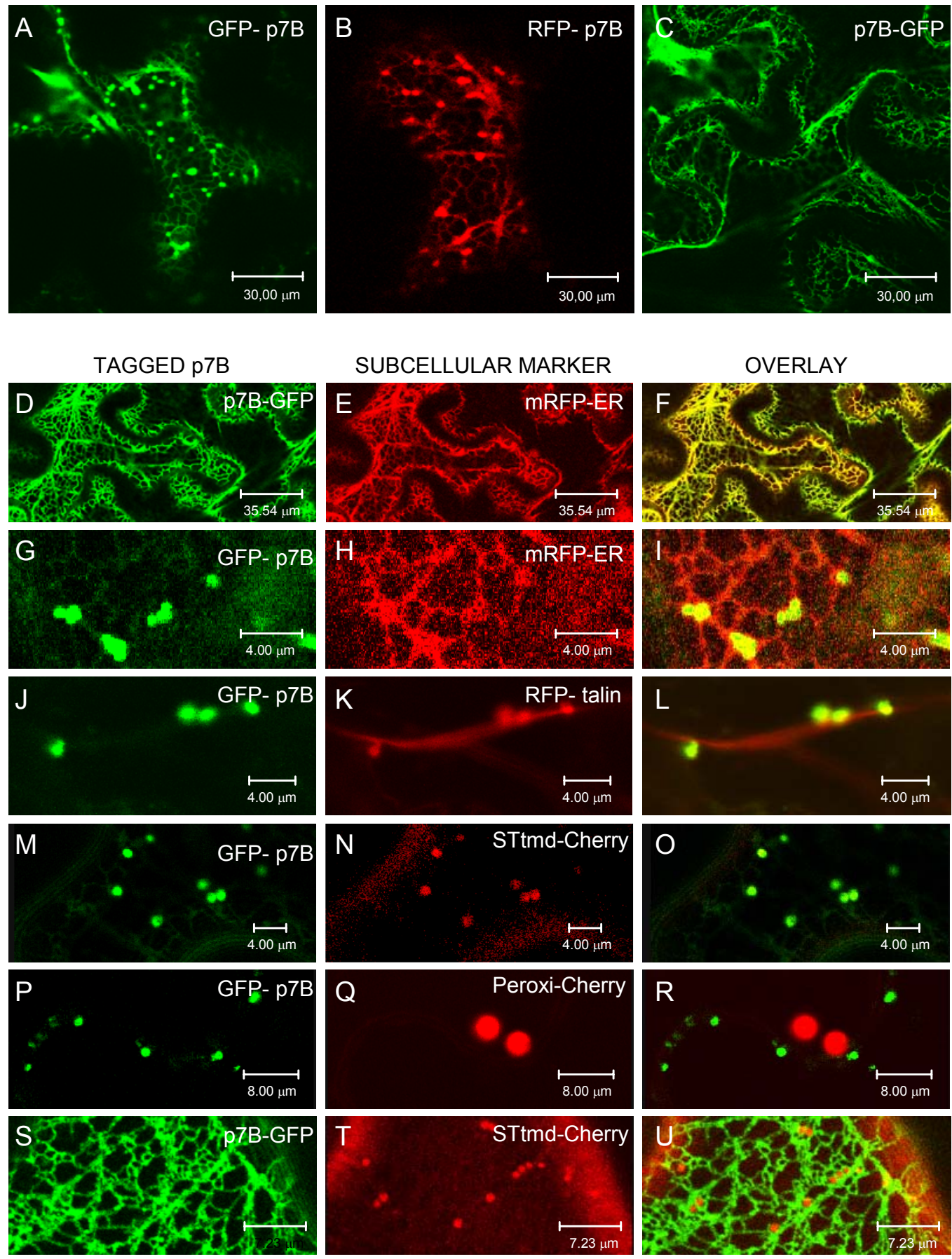

Figure 1. Studies on subcellular localization of different fluorescent tagged p7B by means of the transient expression mediated by $A$. tumefaciens infection in $N$. bentahamina leaves. (A) to (C) Confocal laser scans of epidermal cells expressing GFP-p7B, RFP-p7B and p7B-GFP, respectively, taken at 48 hours post infiltration and showing a fluorescent polygonal network pattern that, in the case of the two former recombinant proteins, also presented numerous networkassociated punctuate bodies. (D) to (U) Confocal laser scans of epidermal cells co-expressing either GFP-p7B or p7BGFP (left image column) together with fluorescent-tagged-markers of different subcellular compartments (middle image column). Overlay images of both red and green channels are displayed in the image column on the right. (D) to (F) Colocalization of the polygonal network labeled by p7B-GFP with an endoplasmic reticulum (ER) marker (mRFP-ER). $(\mathrm{G})$ to (I) GFP-p7B punctuate bodies showing a clear association with the ER stained with mRFP-ER. (J) to (L) GFPp7B punctuate bodies showing a clear association with the actin microfilaments stained with the actin-biding domain of the mouse talin fused to the DsRed fluorescent protein (RFPTalin). (M) to (O) Colocalization of the GFP-p7B punctuate bodies with the Golgi apparatus stacks stained by using the rat $\alpha$-2,6-sialyltransferase fused to the cherry (ChFP) fluorescent protein (STtmdCherry). (P) to $(R)$ No colocalization of the GFP-p7B punctuate bodies with peroxisomes (red signal). (S) to (U) No colocalization of the p7B-GFP ER labeling with Golgi stacks (STtmdCherry) reveals a p7B-GFP retention into the ER membranes and no exit to Golgi apparatus. 
It is possible that the GFP molecule would generate steric impediments that preclude an interaction between the p7B Ct and a putative receptor which is essential for ER-to-Golgi transport. Consistently with this finding it is worthy to note that the over-expression of SED5, a protein required for vesicular transport between the ER and the Golgi complex (Hardwick and Pesman, 1992), has an inhibitory effect on the secretion only when the fluorescent tag is present at the N-terminus. In addition, the length of the transmembrane domain but also export signals have been implicated in export of proteins for ER (Hanton et al., 2006). Taken together, these results indicate that the viral movement protein P7B is initially inserted into the ER as appointed by in vitro assays but later can be exported to Golgi apparatus by means of unidentified export signals.

\section{Nt-tagged-p7B Also Associates to Punctuate Structures at the Cell Boundary but Disruption of ER-to-Golgi Transport Inhibits Forward Trafficking.}

Translocation of proteins into the ER lumen or insertion into the ER membranes represent the first step of the secretory pathway where Golgi apparatus plays an intermediary role into the protein traffic towards a variety of different locations mainly including the cell surface and the pre-vacuolar compartments (PVC) (Jürgens, 2004; Matheson et al., 2006). PVCs are intermediate organelles where secretory and endocityc traffic leads to the lytic and protein storage vacuoles (PSV). In this scenario, additional p7B subcellular localization beyond the Golgi apparatus is possible. To provide further evidences of this putative p7B post-Golgi targeting, a careful observation of confocal scans taken at the z-plane where boundaries between adjacent cells are clearly visible was performed (Figures $2 \mathrm{~A}$ and $2 \mathrm{D}$ ). Interestingly, both transiently expressed GFP-p7B and RFP-p7B in N. benthamiana leaf epidermal cells were also located in punctuate areas at the cell wall that occasionally were detected on opposite sites. It is well established that plant viruses utilize plasmodesmata (PD) for their MP-driven intercellular movement and consequently, it is expected that MPs target to cell wall and to PD by itself but also with the assistance of other factors (Waigmann et al., 2004). Therefore, the GFP-p7B and RFP-p7B fluorescent punctuate pattern observed at the cell wall most likely corresponds to PD rich areas. To verify this supposition, the Tobacco mosaic virus (TMV) MP fused to the mRFP ORF (MP TMV $_{\text {-mRFP) }}$ or the Arabidopsis thaliana Clas 1 reversibly glycosylated polypeptide fused to GFP (AtRGP2GFP) were used as PD markers in coexpression assays with Nt-tagged-p7B. Confocal scans taken at the appropriate z-plane showed clearly colocalization in both combinations, which are: $\mathrm{MP}_{\mathrm{TMV}}-\mathrm{mRFP}$ expressed together the GFP-p7B (Figures 2A-C); and AtRGP2GFP expressed with RFP-p7B (Figures 2DF). Both, the TMV MP and AtRGP2 have been shown labeling PD but the route followed for each one to reach its destination was different. The targeting of TMV MP to PD during infection is mediated by the actin/ER network (Wright et al., 2007) whereas AtRGP2 is delivered to PD via the Golgi apparatus (Sagi et al., 2005). Therefore, it is feasible that MNSV MP reach the PD via the Golgi stacks as the $A$. thaliana protein does. However, considering that p7B was early 
inserted into the ER, a transport to PD along the membrane of the ER network without passage through the secretory system as TMV MP might also take place.

TAGGED p7B
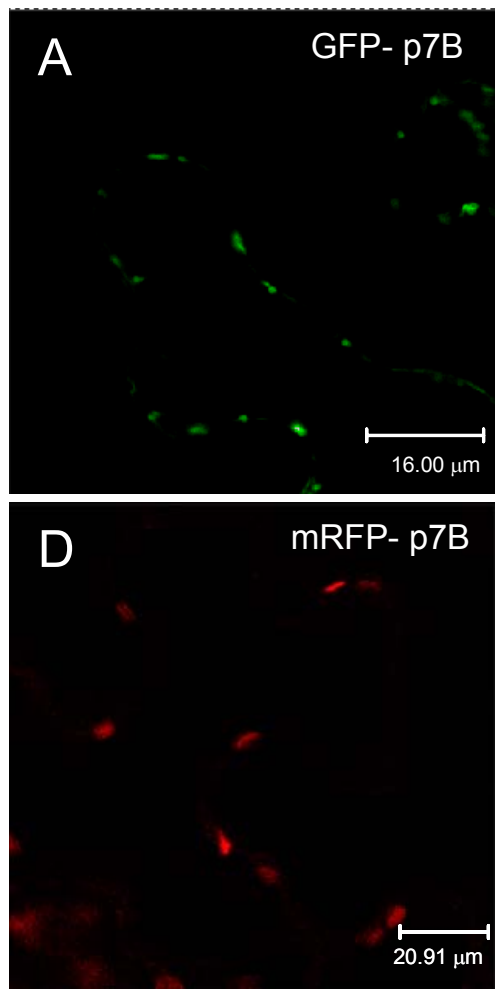

SUBCELLULAR MARKER
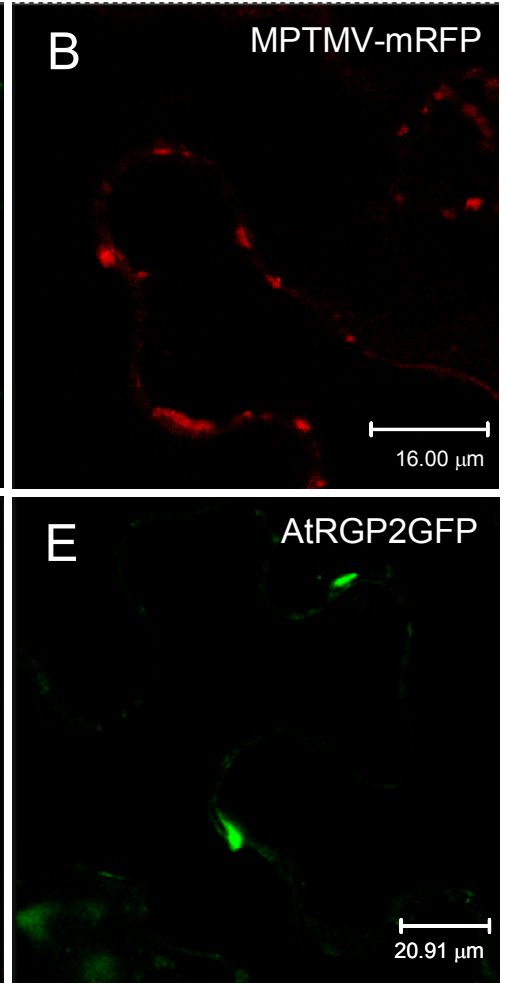

\section{OVERLAY}
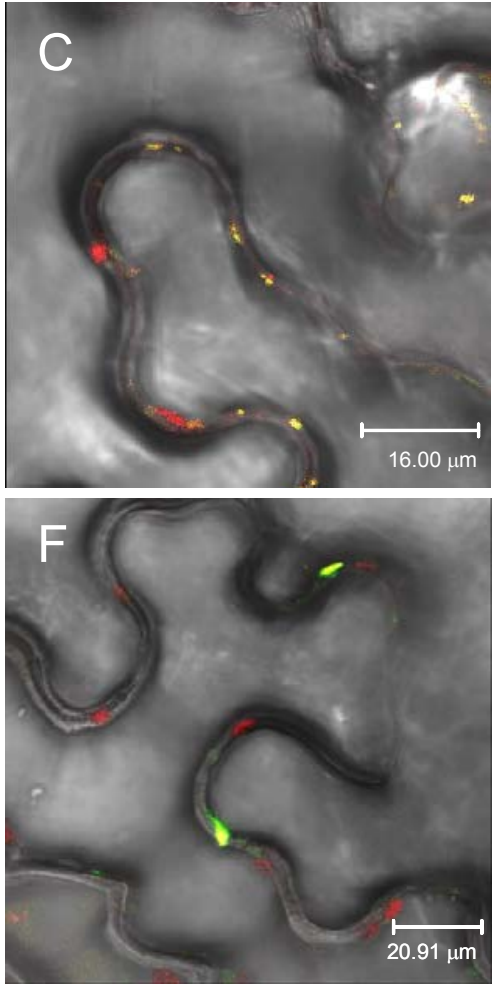

Figure 2. Studies on subcellular localization of Nt-tagged-p7B on the boundaries between adjacent epidermic cells of both GFP-p7B and RFP-p7B by means of the transient expression mediated by $A$. tumefaciens infection in $N$. bentahamina leaves. (A) to (C) Confocal laser scans of epidermal cells co-expressing GFP-p7B and the Tobacco

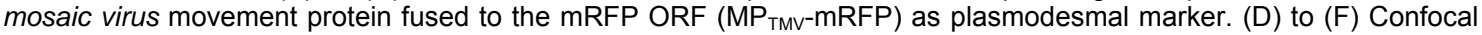
laser scans of epidermal cells co-expressing mRFP-p7B and the Arabidopsis thaliana reversibly glycosylated polypeptide fused to GFP (AtRGP2GFP) to plasmodesmata (PD) labeling. Overlay images of the red, the green and the white light channels showing colocalization of the viral protein and the PD markers on the boundaries between adjacent epidermic cells are displayed in the image column on the right.

Fortunately, the discrimination between both pathways is possible by using the fungal metabolite brefeldin A (BFA). This drug affects both anterograde and retrograde transport between ER and Golgi generating a redistribution of the Golgi enzymes into the ER at low concentrations (5-10 $\mu \mathrm{g} / \mathrm{mL}$ ) (Ritzenthaler et al., 2002) but it appeared has no effect on ER which needs, as PVCs, a high BFA concentration $(100 \mu \mathrm{g} / \mathrm{mL})$ to be disrupted (Tse et al, 2006). To monitor the drug effect on the secretory system, STtmd-ChFP expressing tissue was simultaneously treated. The incubation of the tissue during 5 hour leads to a complete redistribution of the fluorescence from both the GFP-p7B and the Golgi reporter STtmd-ChFP punctuate pattern into the ER (Fig 3B and 3D, respectively), providing additional evidence of subcellular localization of tagged p7B to Golgi stacks but also suggesting that movement protein 
was not further targeted to PD. In this sense, supplementary data corroborating these results were provided by expressing the ER resident p7BGFP fusion protein. In this case, no punctuate fluorescent regions in the plasma membrane of epidermal cells that colocalized with PD markers were observed (data not shown) suggesting that this route to reach the PD is most likely avoided for p7B.
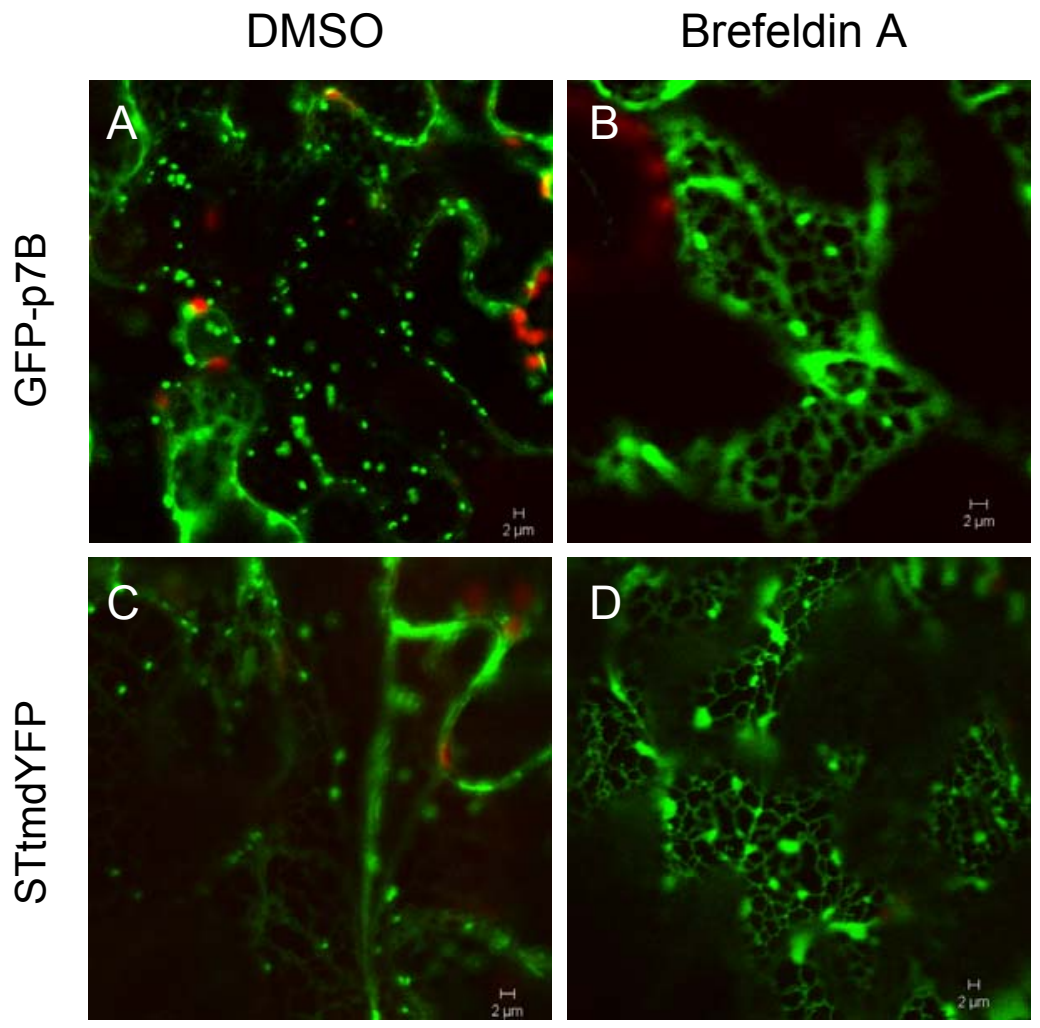

Figure 3. Effect of brefeldin A (BFA) on fluorescence distribution in epidermic cells of $N$. benthamiana leaves transiently expressing either GFP-p7B or the rat $\alpha$-2,6-sialyltransferase fused to the YFP (STtmdYFP). Tissue disc were either immersed into a solution of brefeldin A dissolved into DMSO $(10 \mathrm{mg} / \mathrm{ml})$ or into DMSO alone during $5 \mathrm{~h}$ at $19 \mathrm{~h}$ postinfiltration. The drug treatment led to the complete redistribution of fluorescence derived from GFP-p7B from the Golgi apparatus stack (A) into the endoplasmic reticulum (B). BFA has the same effect in the localization of STtmdYFP (C) and (D).

\section{Dimerization of p7B Through Cys N-terminus Residues Occurs at the Microsomal} Membrane Fraction.

In previous works we and others proposed an arrangement of the carmovirus DGBp2 into two different groups which were referred as MNSV-like and Carnation mottle virus CarMV-like DGBp2 depending on whether the hydrophobic $\mathrm{N}$-terminus acid regions were either distributed along one or two transmembrane domains (TMD), respectively (Matinez-Gil et al., 2007; Navarro et al., 2006; Sauri et al., 2005; Vilar et al., 2002). By having a unique TMD it is temping to speculate that the functional unity of MNSV 7B in its viral cell-to-cell involvement would be the 
dimmer form, as it has been described for 6-kDa transmembrane protein from closteroviruses (Peremyslov et al., 2004). In this sense, several conserved cysteine residues that are present in all homolog MNSV-like but not in CarMV-like DGBp2 Nt could potentially generate intermolecular covalent disulfide bonds. The Nt sequence of p7B has three cysteines located at $\mathrm{Nt}$ positions $\mathrm{C}_{3} \mathrm{C}_{4} \mathrm{C}_{6}$, These $\mathrm{Nt}$ residues were conserved among all available MNSV isolates except for the residue located at position 4, which was replaced by Tyrosine in five cases (data not shown). Interestingly, anomalous Cys-Tyr covalent bonds involving protein interactions have been described (Diaz et al., 2004). With this assumption, a characterization of the p7B form which could be detected in vivo from the ER and Golgi stack membranes was performed by subcellular fractionation of protein extracts derived from the $N$. benthamiana plants either expressing p7BGFP or GFPp7B fusion proteins, respectively. As expected, all the free GFP was present in the soluble fraction (S30) (data not shown) and thus the P30 fraction, which it is established mainly to contain membranous material and cell organelles such as microsomes derived from endoplasmic reticulum (ER) and Golgi stacks, was loaded into the top of $20 \%$ to $60 \%$ linear sucrose density gradient and centrifuged at $100000 \mathrm{~g}$ for $16 \mathrm{~h}$. The gradients were then fractionated and analysed by anti-GFP immunoblotting as illustrated in Figure 4. Extracts from leaves separately expressing GFP, STtmd-YFP and ER-YFP were used as controls for a cytoplasm, a Golgi membrane and an ER luminal marker, respectively. The migration of organelle-specific markers as well as both GFP tagged p7B was similar (a maximum peak was detected between fractions 13-15) (Fig 4). Luminal ER-YFP was highly detected on loading fractions (1-4) most likely due to that the microsomal integrity was compromised for unknown reasons. Interestingly, both GFP tagged p7B were detected as a $35 \mathrm{kDa}$ band corresponding to the molecular size of the monomeric fusion protein but predominantly as another band of approximately $70 \mathrm{KDa}$ matching with the size of the dimer. A minor quantity of both GFP tagged p7B was also present in the soluble fraction (S30) but interestingly, the dimers were never detected (data not shown) suggesting that dimerization greatly depends on the membrane insertion of the monomer.

The contribution of the cysteine residues in p7B dimerization was evaluated by electrophoretic analysis under non-reducing versus reducing conditions of the protein extracts from p7B-GFP P30 fraction. This fusion protein was selected since always presented a rate of dimer formation higher than that obtained with GFP-p7B and, in some cases, only p7B-GFP dimers were still detected (Figure 5 ). In the presence of the redox reagent dithiothreitol (DTT) maintaining $\mathrm{SH}$ groups in reduced state, the p7B-GFP exclusively appeared as the monomer form, whereas the band corresponding to dimers, showing a molecular mass of $70 \mathrm{kDa}$, completely disappeared. Simultaneously, similar results were obtained by using the protein BYV p6 also fused to the GFP which in vivo was previously detected as a homodimer also maintained by disulfide bridges (Peremyslov et al., 2004). Extracts from tissue samples expressing free GFP were used as controls but never showed this dimerization phenomenon 
(data not shown). In this scenario, a cysteine-to-glycine replacement of the three Cys residues by site-directed mutagenesis was used to corroborate the previous results (p7B $\triangle 3 C-G F P)$. ER insertion of p7B $\Delta 3 \mathrm{C}-$ GFP was not affected (data not shown) by the changes introduced but interestingly, the dimerization faculty was lost (Figure 5). Thus, p7B dimerization can be correlated to the disulfide bridge formation by the cysteine residues located in its $\mathrm{Nt}$ extreme $\left(\mathrm{C}_{3} \mathrm{C}_{4} \mathrm{C}_{6}\right)$ and is strongly dependent on the presence of a membraneous fraction.

A

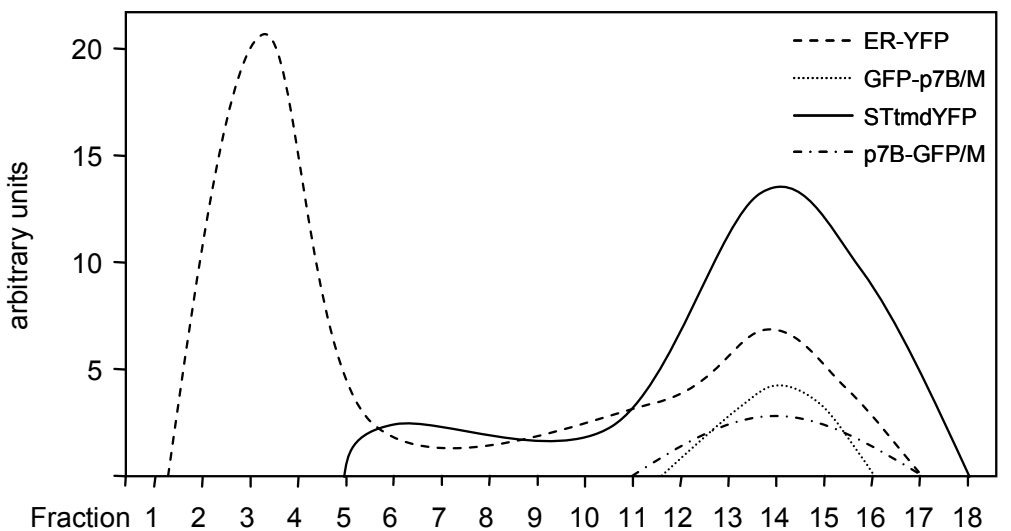

B

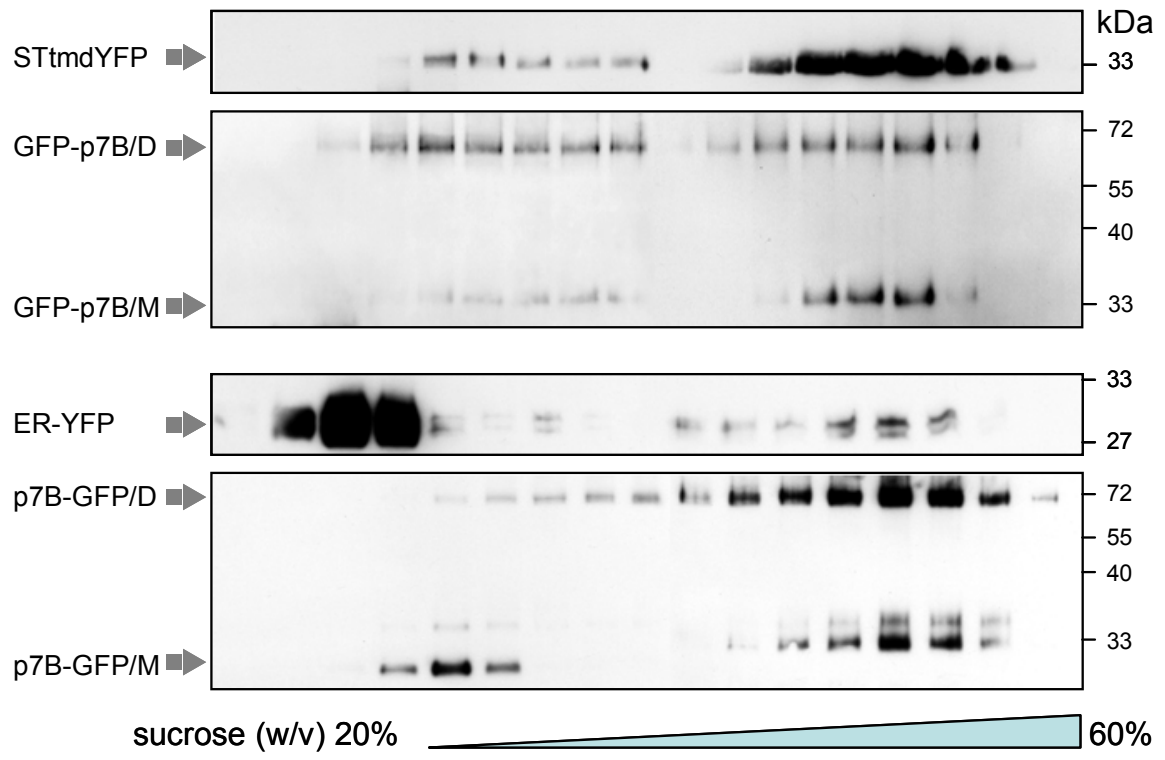

Figure 4. Biochemical localization of both p7B-GFP and GFP-p7B by subcellular fractionation of $N$. benthamiana tissue transiently expressing each protein. The microsomal (P30) fraction was loaded on top of $20 \%$ to $60 \%$ linear sucrose gradients containing lysis buffer with $\mathrm{MgCl}_{2} 1 \mathrm{mM}$ and 18 fractions were taken for immunoblot analysis with a mouse polyclonal antibody against the GFP/YFP. (A) Quantification in arbitrary units of the signals derived from the immunoblot assay of each sucrose gradient fraction showing co-migration of both GFP tagged p7B with a luminal ER marker (ERYFP) but also with a Golgi apparatus marker (STtmdYFP). (B) Immunoblot assays of sucrose gradient fraction from $\mathrm{N}$. benthamiana tissues expressing STtmdYFP (Golgi apparatus marker), GFP-p7B, ER-YFP (endoplasmic reticulum marker) and p7B-GFP. The immunoblot signals corresponding to monomeric (GFP-p7B/M, p7B-GFP/M) and dimeric forms of both GFP tagged p7B are indicated (GFP-p7B/D, p7B-GFP/D). The fractions are numbered from top to bottom (1 to 18$)$ of the gradient. 


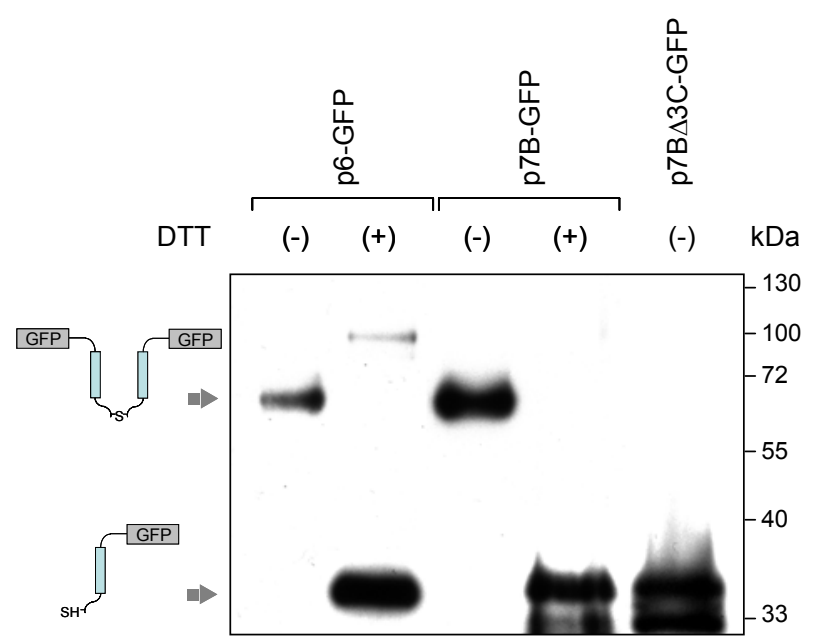

Figure 5. Study about the dimerization ability of the p7B-GFP recombinant protein extracted from P30 microsomal fraction on $N$. benthamiana transiently expressing leaves. Electrophoretic analysis of both MNSV p7B-GFP and BYV p6GFP either under non-reducing (-) or reducing conditions (+) showed that in both cases the dimerization faculty was lost in the presence of the redox reagent dithiothreitol (DTT). Homo-dimerization by means of disulfide bridge formation between the cysteine residues located in the p7B Nt extreme $\left(\mathrm{C}_{3} \mathrm{C}_{4} \mathrm{C}_{6}\right)$ was demonstrated by mutant p7B $\Delta \mathrm{C}$-GFP lacking dimeric forms even in the absence of DTT. The relative position of single and dimeric forms of the recombinant proteins is indicated by a schematic representation of both conformations on the left side.

\section{The p7B can adopt a Dual-Topology into ER Membrane as Deduced from Bimolecular Fluorescence Complementation Assays.}

The formation of disulfide bonds in newly synthesized polypeptide chains into the secretory pathway is a consequence of the protein disulfide isomerase (PDI) activity in the ER luminal space (Frand et al., 2000). Moreover, proteins containing stable disulfide bonds are rarely found in the cytoplasm from any organism (Kadokura et al., 2003). On the basis of these data, the detection of disulfide-linked p7B dimers could indicate that the Cys residues are laying inside the ER and consequently, this protein adopting a type III membrane topology in living cells with its $\mathrm{Nt}$ facing the lumen of the ER in a similar situation to that previously reported for BYV p6 (Peremyslov et al., 2004). However, a significant but variable rate of the protein was also detected as monomer forms in most of the microsomal fractionation assays we performed. This situation is consistent with an opposite orientation of the protein where Cys residues are exposed to the cytoplasmic face and then, making difficult the disulfide bond formation although alternatively, it can be the result of an inefficient PDI activity. Similar duality in the results has been observed in glycosylation site tagging experiments on p7B (Martinez-Gil et al., 2007).

Thus we addressed the question of the insertion mode of p7B into ER membranes from living plant cells by means of a different approach that is based on the bimolecular fluorescence complementation (BiFC) assay (Zamiatnin et al., 2006). We fused both an Nt-terminal Yellow Fluorescent protein (YFP) fragment (residues 1-158, referred to as $\mathrm{N}_{\mathrm{t}}$-[YFP]) and a Ct-terminal YFP fragment (residues 159-238, referred to as $\mathrm{C}_{t}-[Y F P]$ ) to the $\mathrm{Ct}$ of the p7B to generate p7B$\mathrm{N}_{\mathrm{t}}$ [YFP] and p7B-C $\mathrm{C}_{t}[\mathrm{YFP}]$ recombinant proteins, respectively, since we assumed that both fusions must be retained in ER membranes as p7B-GFP does. The level of association of the 
YFP fragments was measured by agrobacterium-mediated co-expression in $N$. benthamiana epidermal cells of both $\mathrm{N}_{\mathrm{t}}$-[YFP] and $\mathrm{C}_{\mathrm{t}}$-[YFP]. Moreover, a gene silencing suppressor (HC-Pro) was added in all BiFC assays as reported (Zamiatnin et al., 2006). The resulting fluorescence pattern was similar to that reported for the free YFP which is distributed between the cytoplasm and nuclei but the re-assembly efficiency was increased by concentrating both fragments into the ER luminal space (compare Figures $6 \mathrm{~A}$ and $6 \mathrm{~B}$ which were taken with identical parameters). In this later case the fluorescence was confined to the ER network. The ER-specific targeting was achieved by expressing both YFP fragments but engineered with the $\mathrm{N}$-terminal signal peptide sequence of Arabidopsis thaliana and the C-terminal ER-retention signal HDEL $\left(\mathrm{SP}-\mathrm{N}_{\mathrm{t}^{-}}\right.$ [YFP]-HDEL and SP-Ct-[YFP]-HDEL) (ER-YN and ER-YC, respectively in Zamiatnin et al., 2006). Moreover, in order to corroborate that each free or ER-tagged fragment of YFP is completely targeted to the appropriated compartment, SP-N $\mathrm{N}_{\mathrm{t}}[\mathrm{YFP}]-\mathrm{HDEL}$ and $\mathrm{C}_{\mathrm{t}^{-}}[\mathrm{YFP}]$ or $\mathrm{N}_{\mathrm{t}^{-}}$ [YFP] and SP-C $\mathrm{C}_{\mathrm{t}}[\mathrm{YFP}]-\mathrm{HDEL}$ were coexpressed. The former combination resulted in no fluorescence detection (Figure 6C) whereas unexpectedly, individual cells dispersed along the tissue showing an ER network distribution of the fluorescence were observed in the later one (Figure 6D). For that reason, the SP- $\mathrm{N}_{\mathrm{t}}-[\mathrm{YFP}]-\mathrm{HDEL}$ and p7B- $\mathrm{C}_{\mathrm{t}}-[\mathrm{YFP}]$ combination and consequently the alternative $\mathrm{N}_{\mathrm{t}}[\mathrm{YFP}]$ and $\mathrm{p} 7 \mathrm{~B}-\mathrm{C}_{\mathrm{t}}-[\mathrm{YFP}]$ were not evaluated. As an alternative, the p7B- $\mathrm{N}_{\mathrm{t}}-[\mathrm{YFP}]$ was either expressed in the presence of $\mathrm{C}_{\mathrm{t}}-[\mathrm{YFP}]$ or SP- $\mathrm{C}_{\mathrm{t}}-[\mathrm{YFP}]-\mathrm{HDEL}$ and unlike BYV p6 (Zamiatnin et al., 2006) the fluorescence was restored in both cases (Figures 6E and $6 \mathrm{~F}$, respectively). However, the signal intensity resulting from the mixture with SP-C $\mathrm{C}_{\mathrm{t}}[\mathrm{YFFP}]-$ HDEL was higher than that obtained with the cytoplasmic $\mathrm{C}_{\mathrm{t}}[\mathrm{YFP}]$ most likely reflecting the previously observed differences between $\mathrm{N}_{\mathrm{t}}-[\mathrm{YFP}] / \mathrm{C}_{\mathrm{t}}-[\mathrm{YFP}]$ and $\mathrm{SP}-\mathrm{N}_{\mathrm{t}^{-}}[\mathrm{YFP}]-\mathrm{HDEL} / \mathrm{SP}-\mathrm{C}_{\mathrm{t}^{-}}$ [YFP]-HDEL combinations but not at stoichiometry proportion. The results indicate that p7B can adopt the two opposite orientations when inserted into ER. This dual topology has been also described for other membrane proteins (von Heijne, 2006).

On the other hand, it has been demonstrated that the positively charged residues prevent the translocation of the domain where are mostly located. Thus, the cytoplasmic domain of membrane proteins contains more positively charged residues than do the opposite domain (the positive-inside rule) (van Geest and Lolkema, 2000). In this sense, as it would be expected for dual-topology proteins, the p7B Nt sequence contains only two positively charged residues $\left(R_{5}\right.$ and $\mathrm{K}_{49}$ ) each one positioned at a different side of the TMD (Fig 7A) unlike the BYV p6 where the cytosolic $\mathrm{Ct}$ contains three positively charged residues vs only one in the Nt luminal end. However, the introduction of three Lys residues downstream of the TMD (between $L_{32}$ and $S_{33}$ ) into p7B- $\mathrm{N}_{\mathrm{t}}$-[YFP] (p7B3K- $\mathrm{N}_{\mathrm{t}}-[\mathrm{YFP}]$ ) does not modify the fluorescence pattern when coexpressed either with SP-C $\mathrm{C}_{\mathrm{t}}-[\mathrm{YFP}]-\mathrm{HDEL}$ or with $\mathrm{C}_{\mathrm{t}}-[\mathrm{YFP}]$ (data not shown). Similar override of the positive-inside rule has been described for the polytopic channel that constitutes the ductin protein (Dunlop et al., 1995). 

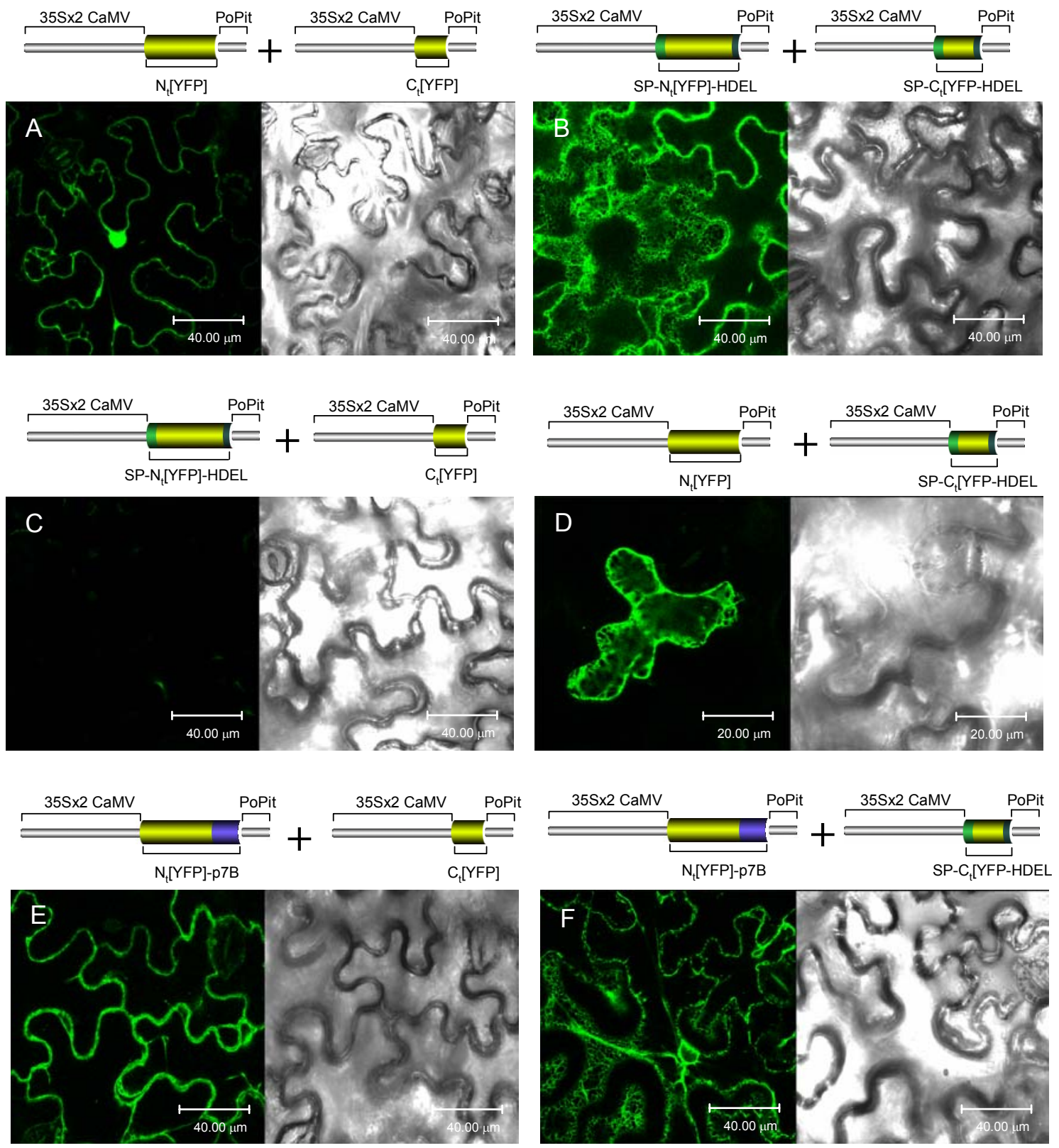

Figure 6. Assessment of the MNSV p7B dual-topology by using the bimolecular fluorescence complementation (BiFC) assay. Fluorescent confocal scans and white light images of epidermal cells of agro-infiltrated $N$. benthamiana leaves expressing $\mathrm{N}_{\mathrm{t}}$-[YFP] and $\mathrm{C}_{\mathrm{t}}$-[YFP] (A), YN-ER (SP- $\mathrm{N}_{\mathrm{t}}$-[YFP]-HDEL) and YC-ER (SP- $\mathrm{C}_{\mathrm{t}}-[\mathrm{YFP}]-\mathrm{HDEL}$ ) (B), YN-ER and $\mathrm{C}_{\mathrm{t}}-[\mathrm{YFP}](\mathrm{C}), \mathrm{N}_{\mathrm{t}}-[\mathrm{YFP}]$ and $\mathrm{YC}-\mathrm{ER}(\mathrm{D}), \mathrm{p} 7 \mathrm{~B}-\mathrm{N}_{\mathrm{t}}-[\mathrm{YFP}]$ and $\mathrm{C}_{\mathrm{t}}-[\mathrm{YFP}](\mathrm{E})$ and, p7B- $\mathrm{N}_{\mathrm{t}}-[\mathrm{YFP}]$ and $\mathrm{YC}-\mathrm{ER}(\mathrm{F})$. A schematic presentation of the expression cassettes for each combination is displayed on top of the corresponding images.

\section{Both Topological and Membrane Insertion Determinants Present in p7B are Required for MNSV Cell-to-Cell Movement.}

In spite of the structural differences found among the numerous integral membrane proteins that have been identified, all of them present universal architectural features most likely forced by the hydrophobic environment in which they are immersed. The membrane spanning 
regions typically present a $\alpha$-helix conformation perpendicularly oriented to the membrane plane which is constituted on average by 20 amino acids (van Geest and Lolkema, 2000). The sequence of the TMD mainly includes hydrophobic (Ala, Ile, Val and Leu) but also the aromatic amino acid Phe in the middle of the domain whereas both Tyr and Trp aromatic residues can be found in the lipid/water interface. In contrast, residues showing charged lateral chains and prolines are largely excluded from the membrane embedded sequence (von Heijne, 2006) except for the functional membrane-buried Pro residues which are selectively included into channel-transport proteins (Deber and Therien, 2002). Finally, the positive-inside rule is an important topological determinant as mentioned before. Here, an accurate site-directed mutagenesis study on the involvement of the topological and membrane insertion determinants, previously described, into the p7B molecule (see Figure 7A for a schematic representation of p7B structure) was performed to map the in vivo structure-to-function relationships in MNSV cell-to-cell movement. The experimental approach consisted on the non-conservative replacement mutations within the p7B ORF by using the recombinant GFP-MNSV clone (pMNSV(Al)- $\Delta \mathrm{cp}-$ GFP) as template (Genoves et al., 2006) and the inoculation of the corresponding in vitro transcripts in melon plants. Therefore, a mutant collection was obtained which affects the topology and membrane insertion determinants of p7B as listed in the Figure 7B. After 2-3 days post inoculation the appearance of fluorescent infection foci was evaluated by confocal microscopy and at least 15 images of individual foci per construct were taken (Figure 7C). The advance on MNSV infection was measured by quantifying the fluorescent area rather than the average diameter of the multi-cellular infection foci due to its irregular shape. The percentage values displayed in the Figure 7B represents the rate between the areas infected by the mutant and the original viral RNA. A $0 \%$ value indicates that cell-to-cell movement was completely impeded since only unicellular foci were observed (Figure 7C).

In order to reduce the hydropathy of the P7B TMD but keeping the $\alpha$-helical folding affected as less as possible, an Ala-scanning involving the hydrophobic Val, Leu and Ile as well as the aromatic Phe and Tyr residues located between $S_{14}$ to the $L_{32}$ positions were performed. The Ala-replacements were initially introduced in triple mutants and the resulting hydropathy of each modified TMD was measured by means of the Membrane Protein Explorer (MPEx) software version 3.0 which is based upon Wimley-White whole-residue hydrophobicity scales (Octanol-Interface combination) and incorporates thermodynamic principles of membrane protein stability (White and Wimley, 1999) (Figure 7B). All of the triple mutants showed a decreasing on its hydropathy that was measured as free energy values $\left(\Delta G_{\text {mut }}=3,01-4,04\right.$ vs $\Delta G_{\mathrm{wt}}=6,19 \mathrm{kcal} / \mathrm{mol}$ ) and resulted on the complete inhibition cell-to-cell movement (Figure 7B and $7 \mathrm{C}$ ). However, the triple mutant $Q_{35} A_{G_{36}} A_{N_{37}} A$ located downstream the TMD but not disturbing the conserved Ct $\beta$-sheet conformation (Navarro et al., 2006) only produced a $20 \%$ reduction in local movement suggesting that most likely TMD hydrophobicity diminution but not the amino acid changes itself was responsible of viral movement hampering (Figure 7B and 
7C). Considering that a hydrophobicity threshold is required for accurate membrane integration of protein segments, we evaluated the putative relation of this phenomenon with the MNSV cellto-cell movement. For this purpose, a progressive reduction into the p7B TMD hydropathy was obtained by introducing single or double ala-replacements into the P7B TMD as shown in the Figure 7B. In this case, MNSV cell-to-cell movement was only maintained when the TMD hydropathy exceeded a threshold value of $5.17 \mathrm{kcal} / \mathrm{mol}$ (obtained with the single mutants $L_{18} A$, $F_{21} A$, or $V_{25} A$ ) although in all competent-movement viral RNAs the spreading was lesser than that obtained with the unmodified construct (Figure 7B and 7C). In any case, the $\alpha$-helix secondary structure of P7B TMD was not disturbed by the ala-replacements as deduced for the consensus structure obtained by means of several computational prediction facilities from SYMPRED server (http://ibivu.cs.vu.nl/programs/sympredwww/) (data not shown). In this sense, statistical studies revealed that $\alpha$-helical membrane-buried regions of non-channel proteins were largely devoid of intramembranous proline residues in accord with structural considerations since the cyclic structure of this amino acid strongly restricts the conformational space resulting in a redirection of the peptide chain (Deber and Therien, 2002). Accordingly to this observation, the $S_{23} P$ replacement introduced in the middle of the TMD also impeded MNSV cell-to-cell movement whereas a slightly reduction on local spread was observed when the serine was replaced for alanine instead of proline (Figure 7B and7C). Thus, structural requirements and hydrophobicity controlling the insertion of p7B TMD appears to be critical for the efficient cell-to-cell movement of MNSV. On the other hand, analyses of TMD from numerous membrane proteins have revealed that aromatic residues, tyrosines in particular, have a propensity to mainly locate at or near the lipid-water interface of the membrane playing an important function in membrane anchoring and stabilization of the corresponding protein. Based on these data, the putative implication of the residues Y13 and Y28 either located immediately upstream or near the $\mathrm{Ct}$ end of the P7B TMD was studied and interestingly local spread of infection was higher than that obtained with original construct (Figure 7B and 7C). In contrast, an approximately $50 \%$ reduction of the local movement was observed in the $\mathrm{Y}_{39} \mathrm{~A}$ replacement most likely due to their location in a conserved region which might be involved in alternative functions different from membrane insertion but also relevant in cell-to-cell movement (Figure 7B and 7C).

Flanking positively charged amino acids determine the final orientation of the hydrophobic transmembrane segments according to the positive inside rule (von Heijne, 1992) but as demonstrated before, p7B can be accommodated in both topologies and it is unclear to what degree the distribution of positively charged lateral chains either affects their topology or consequently, their function. In this aspect, a negative-to-positive inversion of the charge balance present at both the $\mathrm{Nt}$ and $\mathrm{Ct}$ extremes flanking the p7B TMd (initial and final overall charged values of -1 and +2 , respectively at each p7B extreme) was either introduced by $D_{7} R$ or $D_{44} R$ mutations into MNSV quimeric RNAs. In both cases, the cell-to-cell movement was 
drastically reduced to $10-15 \%$ values (Figure $7 B$ and $7 C$ ). Finally, the participation of the dimer conformational state of $\mathrm{p} 7 \mathrm{~B}$ in intercellular movement was also studied by introducing, as performed before for p7B-GFP recombinant protein, a cysteine-to-glycine replacement of the three Cys residues located at the Nt of the protein but using the infectious vector as template. Unlike BYV p6, the ability of MNSV to invade adjacent cells was no completely inhibited but movement was drastically reduced (10\%) (Figure 7B and 7C). Subcellular localization of GFPp7B carrying the cysteine-to-glycine mutation was not modified (Table 1 and Fig 8). Therefore, to fulfill its function in a more efficient manner, the p7B must be present as a dimeric element.

A

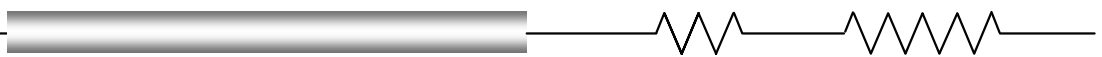

MAC $_{3} \mathrm{C}_{4} \mathrm{RC}_{6} \mathrm{D}_{7} \mathrm{SS}_{9} \mathrm{P}_{10} \mathrm{G}_{11} \mathrm{DY}_{13} \mathrm{SGAL}_{17} \mathrm{~L}_{18} \mathrm{I}_{19} \mathrm{~L}_{20} \mathrm{~F}_{21} \mathrm{I}_{22} \mathrm{~S}_{23} \mathrm{~F}_{24} \mathrm{~V}_{25} \mathrm{~F}_{26} \mathrm{~F}_{27} \mathbf{Y}_{28} \mathrm{I}_{29} \mathrm{TSL}_{32} \mathrm{SSQ}_{35} \mathrm{G}_{36} \mathrm{~N}_{37}$TY Y$_{39}$ VHHFD $_{44}$ NSSVKTQYV $_{53} \mathrm{G}_{54} \mathrm{I}_{55} \mathrm{STNGDG}^{*}$

B

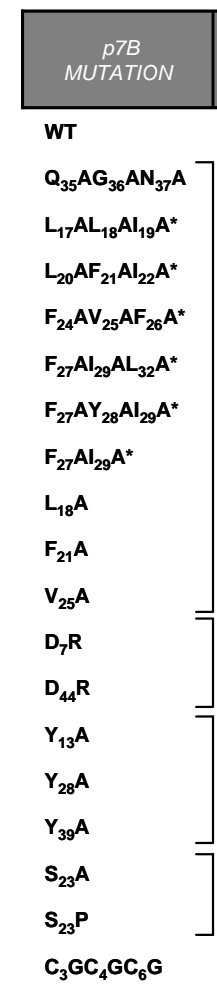

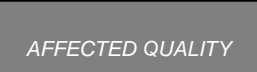

HIDROFOBICITY

6,05

3,01

3,12

3,51

3,12

4,04

4,14

5,17

5,28

5,33

CHARGES

AROMATIC AA

SECONDARY STRUCTURE

DIMMERS
C

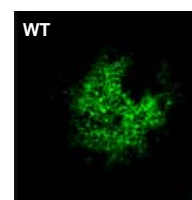

100

80

0

0

0

0

0

72

86

66

12

16

154

123

54

93

0

10

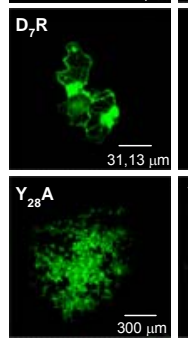

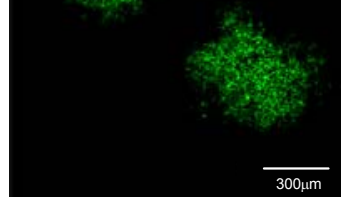
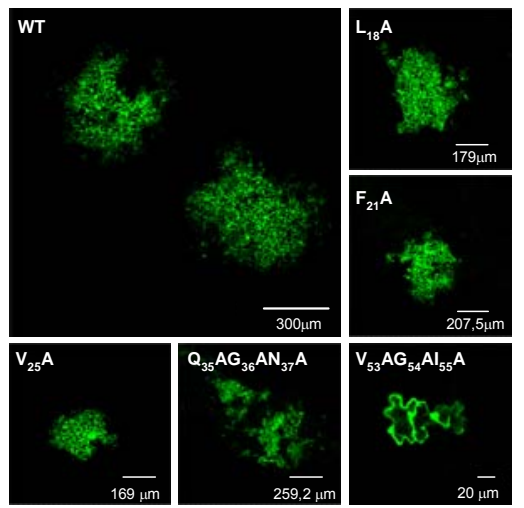

$\mathrm{V}_{53} \mathrm{AG}_{54} \mathrm{Al}_{55} \mathrm{~A}$
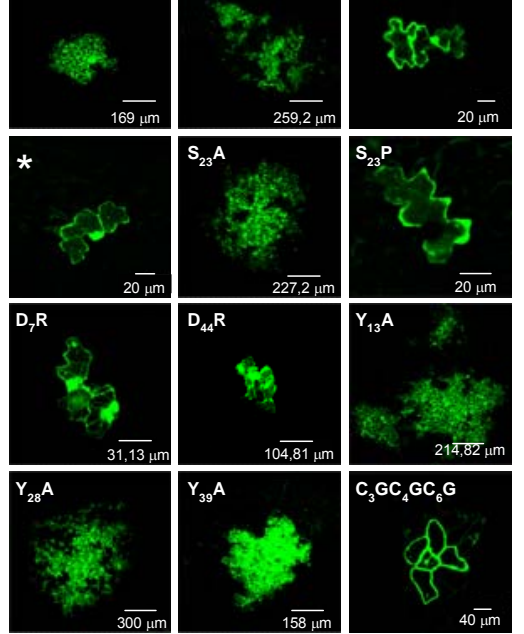

Figure 7. Studies on the contribution of the topological and membrane insertion determinants as well as the dimerization ability of p7B in MNSV cell-to-cell movement in melon plants by site-directed mutagenesis. (A) Schematic representation of the deduced secondary structure of MNSV p7B showing the conserved elements of secondary structure ( $\alpha$-helix and $\beta$-sheet folding are represented by boxes and broken lines, respectively). (B) List of the amino acid replacements performed into the p7B ORF from pMNSV(Al)- $\Delta \mathrm{cp}-\mathrm{GFP}$ construct and the affected determinant, the p7B hydrophaty values resulting after mutation measured as free energy $(\mathrm{kcal} / \mathrm{mol})$ and the relative percentage of infected/fluorescent area obtained after inoculation of quimeric RNAs derived from the original vector and each modified form on melon cotyledons. (C) An image of a representative fluorescent infection focus (muti- and unicellular) taken 2-3 days after inoculation of each MNSV mutant RNAs on melon cotyledons by using a confocal laser microscope is showed. 


\section{Subcellular Localization of p7B into Golgi Stacks is Largely Related to MNSV Cell-to-Cell Movement.}

Correlation between the intracellular traffic of p7B and viral cell-to-cell movement was studied by imaging the subcellular localization corresponding to the mutants analyzed before in the movement assays. To address this issue, we introduced identical modifications as in the case of the viral vector but into the binary construct carrying the GFP-p7B fusion protein. Therefore, based on the alteration of a particular topological and insertion determinant, both competent and deficient movement mutations were selected: 1) the mutants $L_{17} A F_{18} A_{19} A$, $\mathrm{L}_{20} \mathrm{AF}_{21} \mathrm{Al}_{22} \mathrm{~A}$ and $\mathrm{F}_{27} \mathrm{Al}_{29} \mathrm{~A}$ showing a TMD hydropathy reduction and local spreading completely inhibited and the corresponding competent-movement $S_{9} A P_{10} A G_{11} A$ and $Q_{35} A G_{36} A N_{37} A$ mutants used as controls; 2) the $S_{23} P$ mutation most likely distorting the membrane-spanning $\alpha$ helix and the corresponding control $\mathrm{S}_{23} \mathrm{~A}$, both showing identical movement capacities as the triple mutants previously mentioned; 3 ) the $D_{7} R$ and $D_{44} R$ mutations altering the charge balance flanking the TMD which were also selected as representatives of modifications that highly reduced the local advance of infection an finally; 4) the $Y_{13} A$ mutation which significantly improved the efficiency of virus to move from cell-to-cell. $A$. tumefaciens strains either carrying the binary vectors expressing GFP-p7B or each of its variants were coinfiltrated together with the bacterial culture allowing the expression of the trans Golgi marker (STtmdChFP) or PD marker (MPTMV-mRFP) in N. benthamiana leaves (Table 1).

\begin{tabular}{lccc}
\hline p7B MUTATION & AFFECTED QUALITY & STtmdCherry & MpTMVmRFP \\
$\mathbf{W T}$ & HIDROFOBICITY & + & + \\
\hline $\mathbf{S}_{9} \mathbf{A P}_{10} \mathbf{A G}_{11} \mathbf{A}$ & + & + \\
$\mathbf{Q}_{35} \mathbf{A G}_{36} \mathbf{A N}_{37} \mathbf{A}$ & + & + \\
$\mathbf{L}_{17} \mathbf{A L}_{18} \mathbf{A I}_{19} \mathbf{A}^{*}$ & - & - \\
$\mathbf{L}_{20} \mathbf{A F}_{21} \mathbf{A I}_{22} \mathbf{A}^{*}$ & - & - \\
$\mathbf{F}_{27} \mathbf{A I}_{29} \mathbf{A}^{*}$ & - & - \\
$\mathbf{L}_{18} \mathbf{A}$ & + & + \\
$\mathbf{F}_{21} \mathbf{A}$ & + & + \\
$\mathbf{V}_{25} \mathbf{A}$ & & + & + \\
\hline $\mathbf{D}_{7} \mathbf{R}$ & & - & - \\
$\mathbf{D}_{44} \mathbf{R}$ & CHARGES & - & - \\
\hline $\mathbf{Y}_{13} \mathbf{A}$ & & + & + \\
$\mathbf{Y}_{39} \mathbf{A}$ & AROMATIC AA & + & + \\
\hline $\mathbf{S}_{23} \mathbf{A}$ & & + & + \\
$\mathbf{S}_{23} \mathbf{P}$ & SECONDARY STRUCTURE & + & - \\
\hline $\mathbf{C}_{3} \mathbf{G} \mathbf{C}_{4} \mathbf{G C}_{6} \mathbf{G}$ & & + & + \\
\hline & DIMMERS & & + \\
\hline & & + & + \\
\hline & & + & + \\
\hline
\end{tabular}

Table 1: Represents the subcellular co-localization of different GFP-p7B mutants by A. tumefaciens mediated transient expression together with the rat $\alpha$-2,6-sialyltransferase fused to the cherry (ChFP) fluorescent protein (STtmdCherry), to label Golgi apparatus stacks, or the MP of TMV fused to the monomeric red fluorescent protein (mRFP), to label the PD. The corresponding p7B mutation is indicated in left column, wt refers to the unmodified p7B ORF. (+) and (-) tags refer to co-localization or not between both particles, respectively. 
At early stage of the assays (24-36 hours post-infiltration) all the p7B related proteins were properly targeted to the ER membrane as deduced from the observation of the typical polygonal network (data not shown). This situation might be expected since TMD were always predicted by using MPEx computer analysis (data not shown). Nevertheless, considering that the first step of intracellular traffic appeared to be unaffected in all cases, later observations were performed at different periods ranging from 36 to $72 \mathrm{~h}$ post-infiltration. Fluorescent labelling of the ER progressively disappeared suggesting that the protein exit from this subcellular compartment was also apparently unaltered (data not shown). Interestingly, both proteins including the $L_{20} A_{21} A_{22} A$ and the $D_{7} R$ mutation which either impeded the cell-to-cell movement or caused an extremely inefficient advance of the local infection, were found as bright cytoplasmic bodies that did not colocalize with Golgi stacks whereas the rest of assayed proteins that included the wt and its movement-competent variants as well as the $\mathrm{S}_{23} \mathrm{P}$, and the $\mathrm{C}_{3} \mathrm{GC}_{4} \mathrm{GC}_{5} \mathrm{G}$ mutants were perfectly found on them (Figure 8).
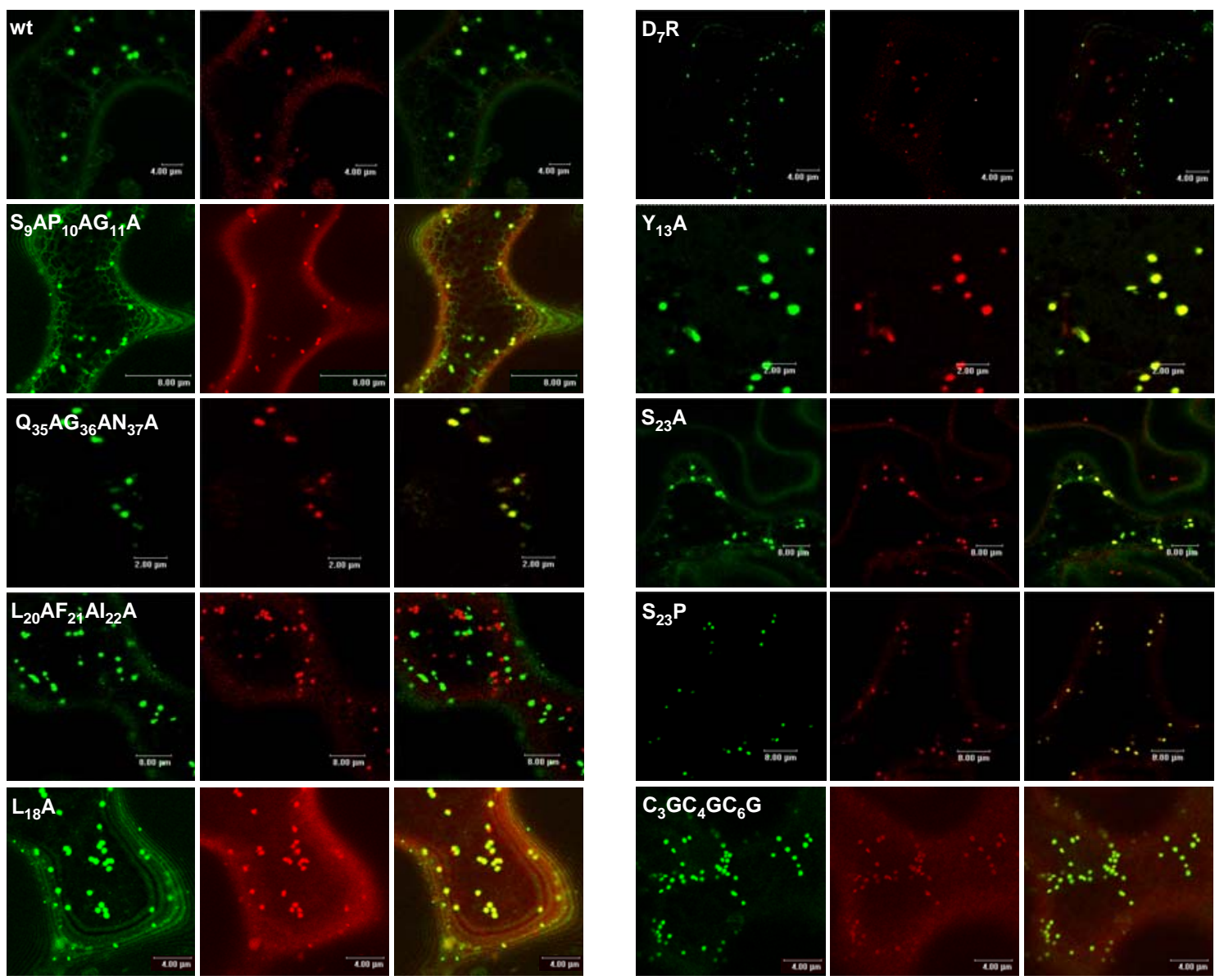

Figure 8. Studies on subcellular localization of different GFP-p7B mutants by means of the transient expression mediated by $A$. tumefaciens infection in $N$. bentahamina leaves. Confocal laser scans of epidermal cells co-expressing GFP-p7B (left image column) together with the rat $\alpha$-2,6-sialyltransferase fused to the cherry (ChFP) fluorescent protein (STtmdCherry) to label Golgi apparatus stacks (middle image column). Overlay images of both red and green channels are displayed in the image column on the right. The corresponding p7B mutation is indicated in the upper side of the panels located on the left column. wt refers to the unmodified p7B ORF. 


\section{Disruption of the ER-Golgi traffic by Brefeldin A results in a reduction of MNSV cell-to-cell movement}

Further evidences correlating the Golgi-mediated traffic to PD of p7B and the local spread of MNSV were obtained by evaluating what effect the disruption of the ER-Gogi transport of cargo molecules by Brefeldin A treatment had on MNSV cell-to-cell movement. For this purpose, quimeric MNSV(Al)- $\Delta \mathrm{cp}-\mathrm{GFP}$ RNAs were inoculated into a number of melon cotyledons which were subsequently treated with the drug by using an established infiltration procedure (Sagi et al, 2005). Considering that monitoring of local movement of this quimeric RNAs requires several days and Golgi transport might be restored when Brefeldin A is removed, the treatment was repeated at different times to maintain the drug presence into the tissue as much as possible. Initial application $(10 \mathrm{mg} / \mathrm{mL}$ ) was performed at 2 days post inoculation when all the infection sites were detected as multi-cellular foci as previously reported (Genoves et al, 2006). However, only foci showing a fluorescent area lesser than $1 \mathrm{~mm}^{2}$ were included into the progress infection analysis to asses that virus was actively moving forward. At this point $(t=0)$, each individual focus was identified by image recording of the non-scissed cotyledon with a stereoscopic microscope to allow the subsequent visualization of the same tissue. Then, the increasing of the fluorescent area was calculated at $\mathrm{t}=24 \mathrm{~h}, 48 \mathrm{~h}$ and $72 \mathrm{~h}$ by computer-assisted analysis of the photographs by using ImageJ v 1.37 software. Since Brefeldin A was diluted into DMSO, control assays were simultaneously performed by infiltrating only this solvent into a halfpart of the melon cotyledons. Infections advance in drug-treated cotyledons was completely stopped but fluorescence was maintained suggesting that replication was most likely unaffected. In contrast, MNSV local infection in DMSO-treated cotyledons clearly progressed and in some cases the final extension of the infected area was approximately three-fold bigger than that of the initial focus (Figure 9). Additionally, fluorescent areas from drug-treated and untreated tissues were sliced to discard non-infected tissue and total RNAs were extr acted. Northern-blot hybridisation with an antisense specific ribobrope from GFP revealed that the MNSV genomic and both subgenomic RNAs were multiplied and accumulated at approximately the same amounts (data not shown).

To discard that the effect of Brefeldin A treatment on MNSV cell-to-cell movement could be the consequence of an indirect effect due to a general de-organization of plant cellular functions an additional control on transgenic $N$. tabacum p12 plants expressing the Alfalfa mosaic virus (AMV) replicase protein was performed by mechanically inoculation of a quimeric AMV RNA 3 not only including the AMV MP and CP ORFs but also the GFP gene (SanchezNavarro et al, 2001). The tubule-forming AMV MP belongs to the "30K superfamily" (Kasteel et al., 1997; Melcher, 2000) and most likely it is trafficked to PD through Golgi-independent routes as has been described for other members of this MP cluster. Leaves were either treated with Brefeldin A or DMSO and the AMV infection progress was visualized as before. In this occasion there was no significant difference in the area of the GFP-fluorescence foci between control and 
BFA-treated leaves, indicating that BFA did not inhibit the cell-to-cell movement of AMV as has been reported for the Tomato mosaic virus (ToMV) which also posses a "30K superfamily" MP (Tagami and Watanabe, 2007).
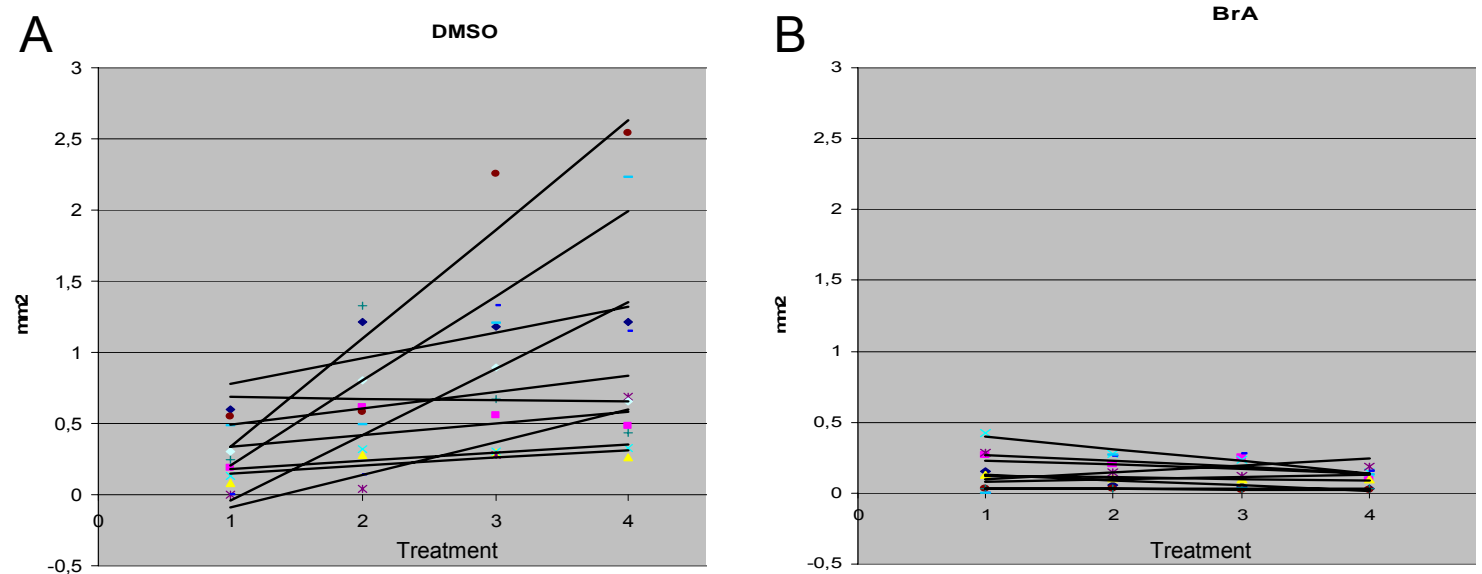

Figure 9: Representation of MNSV(Al)- $\triangle \mathrm{cp}$-GFP infection foci area growing in melon cotyledons tissues in presence of DMSO $(A)$ or Brefeldin A (B). Y axis represents the foci diameter $(\mathrm{mm} 2)$ and $X$ axis represents the time of treatment $(1=$ Oh, $2=24 \mathrm{~h}, 3=48 \mathrm{~h}, 4=72 \mathrm{~h}$ ).

\section{DISCUSSION}

\section{The p7B Viral Movement Protein Is Targeted to PD by Means of a Golgi-Mediated Pathway}

Recent studies regarding the structural properties of $\mathrm{p7B}$ revealed the presence of a single-spanning membrane domain that allows their co-translational insertion into ER-derived microsomal membranes (Navarro et al., 2006; Martinez-Gil et al., 2007). However, no further information concerning to the subcelular compartment where this protein is targeted within the cell could be obtained from these assays since they were performed by using an in vitro cellfree experimental system. For that reason, we report here the p7B subcelular localization in plant cells which also provided interesting evidences about how intracellular movement take place given that the location of this protein underwent a spatio-temporal variation. Thus, $\mathrm{p7B}$ was initially positioned at the ER reaching out from the external nuclear envelope to the polygonal network of the cortical regions but later was also detected into the trans-GA stacks and the PD. The fact that the secretory pathway inhibitor BFA fully retained the p7B derived fluorescence into ER by stopping the MP traffic to Golgi bodies and PD suggested that the delivering to this later destination could be mediated by a GA-dependent pathway. The PD is most likely the functional final target of p7B into the viral life cycle whereas GA might be an intermediate organelle where the protein is in transit. Therefore, the visualization of p7B into the GA was probably reflecting a large production of the protein in a very short time during transient 
expression. These results are quite similar to those reported for the PD-associated cellular class 1 reversibly glycosylated polypeptide RGP2 from Arabidopsis thaliana which also follows a GAmediated route (Sagi et al., 2005). However, some differences could be noted; early association of RGP2 to the ER was neither observed during transient expression assays nor after BFA treatments. Instead of this, an additional cytoplasm distribution of the protein was detected (Drakakaki et al., 2006; Sagi et al, 2005). This situation is most likely reflecting the differences in membrane association between both p7B and RGP2 that could determine the entry point at which each protein is tracked into the secretory pathway. It is known that the entrance to the endomembrane system for newly sinthesized proteins is mediated by the ER (van Geest and Lolkema, 2000). Nascent polypeptides are cotranslationally transported into this subcelular compartment by the translocon machinery that in the case of membrane proteins could stop the transfer to integrate them in the lipid bilayer as is most likely the case of the p7B (Martinez-Gil et al., 2007). Unlike, RGPs are soluble proteins that are peripherally associated to the cytosolic face of GA membranes and subsequently could be directly targeted from cytosol to GA without the involvement of the ER.

\section{Dual Topology of p7B Could Represent an Initial Step in Evolution Toward CarMV-like DGBp2}

Carmovirus DGBps2 were assigned into two different groups, MNSV-like and CarMV-like proteins, depending on the hydrophobic amino acids were either distributed along one or two transmembrane $\alpha$-helices, respectively. Additionally, a conserved sequence folding as a $\beta$-sheet structure was predicted at the C-terminus of both groups suggesting an equivalent functional involvement (Navarro et al., 2006). Interestingly, biochemical assays reveals a topological arrangement of CarMV DGBp2 with both $\mathrm{Nt}$ and $\mathrm{Ct}$ facing the cytosol whereas the TMDconnecting loop is positioned inside the ER luminal space (Vilar et al., 2002). In this scenario, the positive inside rule seems to be accomplished for all DGBp2 members of CarMV-like cluster (see the Figure 1 in Navarro et al., 2006). On the other hand, BiFC assays indicated that p7B can adopt a dual-topology in the ER membrane showing both opposite orientations. Moreover, the positive inside rule was apparently overridden as a mutant p7B engineered to have a $\mathrm{Ct}$ cytosolic orientation also showed both topological orientations. However, the ability of p7B to form Ct-cytosolic homo-dimers was here demonstrated to be essential for an efficient MNSVcell-to-cell movement but also an appropriate charge balance around the TMD as deduced from the $D_{7} R$ and $D_{44} R$ mutations. Appropriate rate of opposite orientations seems to be necessary for the ER-to-GA MP export since the introduction of $D_{7} R$ mutation generated a delivering of the protein to non-GA punctuate bodies. In any case, p7B homo-dimer elements with a Ct cytosolic orientation as well as molecules presenting an opposite orientation both play a functional role in MNSV intra- and consequently inter-cellular movement. This situation resembles that of CarMVlike DGBp2 proteins showing two TMD with both $\mathrm{Nt}$ and $\mathrm{Ct}$ regions facing to cytosol. Perhaps, MNSV-like DGBp2 could represent an initial step in evolution toward CarMV-like DGBp2. In this 
sense, it has been recently shown that membrane proteins initially presenting a dual topology may undergoes a complete gene duplication which results in two similar ORFs but each one showing opposite orientations most likely due to a redistribution of positive charged residues; finally, a fusion event between both homologous genes may generate a single protein with two opposite TMD (Rapp et al., 2006). Therefore, MNSV-like and CarMV-like DGBp2 represent different steps in the evolution of carmoviruses MP.

\section{ER-to-Golgi transit is necessary but not sufficient for MNSV Cell-to-Cell Movement that Most Likely Requires a Functional Secretory Pathway}

Relationships between intracellular traffic of p7B and MNSV cell-to-cell movement was evaluated in this work by disruption the topological and membrane insertion determinants of p7B by site-directed mutagenesis into a quimeric GFP/MNSV viral. Reduction of p7B TMD hydrophobicity resulted in a drastic inhibition of cell-to-cell movement but a threshold hydropathy value appears to exist that once surpassed restored the intercellular advance of the virus. It is possible that ER insertion of p7B could be impeded into non-competent movement proteins since it is known that hydrophobicity value dictates when a peptide can adopt a fully $\alpha$ helical structure inside a membrane environment. However, either the $L_{17} A F_{18} A l_{19} A$, the $\mathrm{L}_{20} \mathrm{AF}_{21} \mathrm{Al}_{22} \mathrm{~A}$ or $\mathrm{L}_{27} \mathrm{Al}_{29} \mathrm{~A}$ mutants showing a great $T M D$ hydropathy reduction were inserted into ER membranes although exported to unidentified punctuates bodies within cytoplasm unlike the competent-movement $S_{9} A G_{11} A Y_{13} A$ and $Q_{35} A G_{36} A N_{37} A$ mutants that were correctly exported to $G A$. Then, the TMD hydropathy reduction resulted in a different destination of $p 7 B$ which was not functional in viral movement. These data are suggesting that the appropriate targeting of p7B could be determined by protein-lipid interactions which possibly are dictated by the hydrophobicity levels of its TMD. At this point, it is interesting to mention that steric impediment at the carboxyl terminus of p7B completely retained the protein at the ER membranes indicating that other factors controlling the export could be located at this region. Moreover, they must be dominant over trans-membrane domain length in defining ER exit. In this sense, any of the dihydrophobic, di-basic, di-acidic and di-aromatic motifs that have been involved in the plant ERto-Golgi traffic of single-spanning membrane proteins were observed in the p7B molecule (Barlowe, 2003) except for a putative $Y X X \Phi$ motif (were $Y$ is Tyr, $X$ is any amino acid, and $\Phi$ is an amino acid with a bulky hydrophobic side chain) that has been noted in some movement proteins from different virus. It has been reported that this sequence element indicates an involvement of secretory and/or endocitic vesicles in their intracellular movement (Boevink and Oparka, 2005). However, excluding the Pea steam necrotic virus, the presence of YXXФ motif was not conserved among carmoviruses DGBp2. Therefore, further investigation is necessary to identify the putative signal export.

A different situation was observed in the case of the $S_{23} P$ mutation most likely distorting the membrane-spanning $\alpha$-helix and the corresponding control $S_{23} A$ since both were trafficked 
from ER-to-GA. Appropriate membrane insertion of $p 7 B S_{23} P$ mutant was not unexpectedly since a widespread occurrence of this sort of residue in TM helices has not only been reported but also functionally involved in transporter proteins (Deber and Therien, 2002). However, drastic differences were observed in their MNSV movement capacities that were completely inhibited in the $\mathrm{S}_{23} \mathrm{P}$ mutant but were only slightly affected in the control. Therefore, subcellular localization of p7B in the Golgi apparatus is a necessary but not sufficient condition to an efficient MNSV cell-to-cell movement take place. This is a reasonable assumption considering that the Golgi apparatus is an intermediate organelle of the secretory/vacuolar pathway and, since the $S_{23} P$ mutant is not locate in the PD (Table 1), the post-Golgi transport of this cargo molecules to its functional destination is hampered According to the observation that movement-competent p7B modifications do not affect their GA location, the p7B molecules carrying the $Y_{13} A$ and $Y_{39} A$ mutations were also trafficked from ER-to-GA but surprisingly, in the former the virus efficiency to move from cell-to-cell was significantly improved. This $Y_{13}$ residue is located at the end of the TMD and after membrane insertion most likely is positioned at the membrane-water interface. Interfacial aromatic residues, commonly found among membrane proteins, are important in both positioning and anchoring of the TMD in the lipid bilayer. In this sense, the bacteriophage M13 major coat protein move into the water phase after alareplacement of two Phe anchoring residues (Stopar et al., 2006). In this scenario, the precise positioning of $\mathrm{p7B}$ in the membrane might be not essential for its functional role but additionally, lack of anchoring restrictions into lipid bilayer could favours a more efficient transport of the p7B along the membranous compartments and consequently, a major advance of local MNSV infection. Alternatively, a large capability to evade proteasome degradation by $\mathrm{Y}_{13} \mathrm{~A}$ mutant can not be ruled out. In fact, the TMV MP mutants have been described with improved transport functions due to their ability to evade this mechanism degradation (Gallespie et al., 2002). In summary, all these data together with the drastic MNSV cell-to-cell movement arresting after inhibition of the ER-to GA traffic in the presence of brefeldin A (Figure 9) strongly indicated that p7B tracks the secretory pathways to achieve the PD in order to MNSV can move from cell-tocell.

\section{Towards a Model for Carmovirus Cell-to-Cell Movement}

The GA-assisted delivering of a protein to PD is not a new finding. In addition to the above mentioned RGP, GA participates in the formation of both primary and secondary branched PD during cell division (Ehlers and Kollmann, 2001) and, in tubule-forming virus studies, circumstantial evidences have involved the secretory pathway in the transport to PD of an unknown factor essential for tubule forming. However, our results represent the first direct evidence that Golgi-mediated traffic of a plant viral protein to PD was essential for viral cell-tocell movement and significantly, a recently reported dual localization of the genome binding p7A, the DGB counterpart of p7B, in both GA bodies and peripheral punctuate structures (Genoves et al., 2007) most likely guarantee this route as that used for MNSV in their 
intracellular movement. The p7A was periphellically associated to the cytosolic face of the GA whereas p7B has a transmembrane region crossing the Golgi membrane but both MNSV MPs were autonomously delivered to the cellular periphery. Then, it is possible that MNSV genome associated to p7A arrives to the PD plasmalemma facing the cytoplasmic sleeve whereas p7B might become inserted into plasmalemma exposing the soluble domains to both the apoplast and cytoplasmic sleeve. Therefore, interaction between both proteins may occur at this location to allow movement-competent complex to reach the adjacent cell after PD traversing. 


\section{REFERENCES}

Aparicio F., Sanchez-Navarro J.A., and Pallas, V. (2006) In vitro and in vivo mapping of the Prunus necrotic ringspot virus coat protein C-terminal dimerization domain by bimolecular fluorescence complementation. J. Gen. Virol. 87, 1745-1750.

Ashby, J., Boutant, E, Seemanpillai, M., Groner, A., Sambade, A., Ritzenthaler, C., Heinlein, M. (2006). Tobacco mosaic virus movement protein functions as a structural microtubule-associated protein. J. Virol. 80, 12433-12433.

Barlowe C. (2003). Signals for COPII-dependent export from the ER: what's the ticket out?. Trends Cell. Biol. 13, 295-300.

Baulcombe, D.C., Chapman, S., and Santa Cruz, S. (1995). Jellyfish green fluorescent protein as a reporter for virus infections. Plant J. 7, 1045-1053.

Boevink, P., and Oparka, K. J. (2005). Virus-host interactions during movement processes. Plant Physiol. 138, 1815-1821.

Boevink, P., Oparka, K., Santa Cruz, S., Martin, B., Betteridge, A., and Hawes, C. (1998). Stacks on tracks: the plant Golgi apparatus traffics on an actin/ER network. Plant J. 15, 441447.

Boyko, V., Hu, Q., Seemanpillai, M., Ashby, J., and Heinlein, M. (2007). Validation of microtubule-associated Tobacco mosaic virus RNA movement and involvement of microtubule-aligned particle trafficking. Plant J.

Bozarth, C.S., Weiland, J.J., and Dreher, T.W. (1992). Expression of ORF-69 of Turnip yellow mosaic virus is necessary for viral spread in plants. Virology 187, 124-130.

Curin, M., Ojangu, E., Kateryna Trutnyeva, K., Ilau, B., Truve, E., and Waigmann, E. (2007). MPB2C, a Microtubule-Associated Plant Factor, Is Required for Microtubular Accumulation of Tobacco Mosaic Virus Movement Protein in Plants 1. Plant Physiol. 143, 801-811.

Deber, C.M., and Therien, A.G. (2002). Putting the $\beta$-breaks on membrane protein misfolding. Nature Struct. Biol. 9, 318-319.

Diaz, A., Horjales, E., Rudino-Pinera, E., Arreola, R., and Hansberg, W. (2004). Unusual Cys-Tyr covalent bond in a large catalase. J. Mol. Biol. 342, 971-985.

Drakakaki, G., Zabotina, O., Delgado, I., Robert, S., Keegstra, K., and Raikhel, N. (2006). Arabidopsis reversibly glycosylated polypeptides 1 and 2 are essential for pollen development. Plant Physiol. 142, 1480-1492.

Dunlop, J., Jones, P.C., and Finbow, M.E. (1995). Membrane insertion and assembly of ductin a polytopic channel with dual orientations. EMBO J. 14, 3609-3616.

Ehlers, K., and Kollmann, R. (2001). Primary and secondary plasmodesmata: Structure, origin, and functioning. Protoplasma 216, 1-30.

Ferralli, J., Ashby, J., Fasler, M., Boyko, V., and Heinlein, M. (2006). Disruption of microtubule organization and centrosome function by expression of Tobacco mosaic virus movement protein J. Virol. 80, 5807-5821. 
Frand, A.R., Cuozzo, J.W., and Kaiser, C.A. (2000). Pathways for protein disulfide bond formation. Trends Cell Biol. 10, 203-210.

Gillespie, T., Boevink, P., Haupt, S., Roberts, A.G., Toth, R., Valentine, T., Chapman, S., and Oparka, K.J. (2002). Functional analysis of a DNA-shuffled movement protein reveals that microtubules are dispensable for the cell-to-cell movement of tobacco mosaic virus. Plant Cell. 14, 1207-1222.

Genoves, A., Navarro, J.A., and Pallas, V. (2006). Functional analysis of the five Melon necrotic spot virus genome-encoded proteins. J. Gen. Virol. 87, 2371-2380.

Hanton, S.L., Matheson, L.A., and Brandizzi, F. (2006). Seeking a way out: export of proteins from the plant endoplasmic reticulum. Trends Plant Sci. 11, 335-343.

Hardwick, K.G., and Pelham, H.R. (1992). SED5 encodes a 39-kD integral membrane protein required for vesicular transport between the ER and the Golgi complex. J Cell Biol. 119, 513521.

Haup, S., Cowan, G.H., Ziegler, A., Roberts, A.G., Oparka, K.J., and Torrance, L. (2005). Two plant-viral movement proteins traffic in the endocytic recycling pathway. Plant Cell 17, 164-181.

Hawes, C., and Satiat-Jeunemaitre, B. (2005) The plant Golgi apparatus-going with the flow. Biochim. Biophys. Acta 1744, 93-107.

Hibi, T., and Furuki, I. (1985). Melon necrotic spot virus. CMI: AAB Descriptions of Plants Viruses $\mathrm{N}^{\circ} 302$.

Holweg, C. L. (2007). Living markers for actin block myosin-dependent motility of plant organelles and auxin. Cell Motil. Cytoskeleton 64, 69-81.

Hull, R. (2002). Virus movement through the plant and effects on plant metabolism. In Matthews' plant virology, 4th edn, pp 373-436. Edited by Academic Press, San Diego.

Ju, H.-J., Brown, J.E., Ye, C.-M., and Verchot-Lubicz, J. (2007). Mutations in the central domain of Potato virus $X$ TGBp2 eliminate granular vesicles and virus cell-to-cell trafficking. J. Virol. 81, 1899-1911.

Jürgens, G. (2004). Membrane trafficking in plants. Ann. Rev. Cell Dev. Biol. 20, 481-504.

Kadokura, H, Katzen, F., and Beckwith, J. (2003). Protein disulfide bond formation in prokaryotes. Anu. Rev. Biochem. 72, 111-135.

Kasteel, D.T.J., vanderWel, N.N., Jansen, K.A.J., Goldbach, R.W., and vanLent, J.W.M. (1997). Tubule-forming capacity of the movement proteins of alfalfa mosaic virus and brome mosaic virus, J. Gen. Virol. 78, 2089-2093

Kawakami, S., Watanabe, Y., and Beachy, R.N. (2004). Tobacco mosaic virus infection spreads cell to cell as intact replication complexes. Proc. Natl. Acad. Sci. U S A. 101, 62916296.

Knoester, M., van Loon, L.C., van den Heuvel, J., Hennig, J., Bol, J.F. and Linthorst, H.J.M. (1998). Ethylene-insensitive tobacco lacks nonhost resistance against soil-borne fungi. Proc. Natl. Acad. Sci. U S A. 95, 1933-1937. 
Laporte, C., Vetter, G., Loudes, A., Robinson, D.G., Hillmer, S., Stussi-Garaud, C., and Ritzenthaler, C. (2003). Involvement of the secretory pathway and the cytoskeleton in intracellular targeting and tubule assembly of Grapevine fanleaf virus movement protein in tobacco BY-2 Cells. Plant Cell 15, 2058-2075.

Li, W.Z., Qu, F., and Morris, T.J. (1998). Cell-to-cell movement of Turnip crinkle virus is controlled by two small open reading frames that function in trans. Virology 244, 405-16.

Lucas, W. J. (2006). Plant viral movement proteins: Agents for cell-to-cell trafficking of viral genomes. Virology 344, 169-184.

Marcos, J.F., Vilar, M., Perez-Paya, E., and Pallas, V.. (1999). In vivo detection, RNA-binding properties and characterization of the RNA-binding domain of the p7 putative movement protein from Carnation mottle carmovirus (CarMV). Virology 255, 354-365.

Martínez-Gil, L., Saurí, A., Vilar, M., Pallas, V., and Mingarro, I. (2007). Membrane insertion of the p7B movement protein of Melon necrotic spot virus (MNSV). Virology (in press).

Matheson, L.A., Hanton, S.L., and Brandizzi, F. (2006).Traffic between the plant endoplasmic reticulum and Golgi apparatus: to the Golgi and beyond. Curr. Opin. Plant Biol. 9, 601-609.

Melcher, U. (2000). The '30K' superfamily of viral movement proteins. J. Gen. Virol. 81, 257266.

Moreau, P., Brandizzi, F., Hanton, S., Chatre, L., Melser, S., Hawes, C., and SatiatJeunemaitre, B. (2007). The plant ER-Golgi interface: a highly structured and dynamic membrane complex. Journal of Experimental Botany 58, 49-64.

Morozov, S.Y., and. Solovyev, A.G. (2003). Triple gene block: modular design of a multifunctional machine for plant virus movement. J. Gen. Virol. 84, 1351-1366.

Muench, D.G., and Mullen, R.T. (2003). Peroxisome dynamics in plant cells: a role for the cytoskeleton Plant Sci. 164, 307-315.

Navarro, J.A., Genoves, A., Climent, J., Sauri, A., Martinez-Gil, L., Mingarro, I., and Pallas, V. (2006). RNA-binding properties and membrane insertion of Melon necrotic spot virus (MNSV) double gene block movement proteins. Virology 356, 57-67.

Nelson, R. S., and Citovsky. V. (2005). Plant viruses. Invaders of cells and pirates of cellular pathways. Plant Physiol. 138, 1809-1814.

Overall, R.L. (1999). Structure of plasmodesmata. In Plasmodesmata, Structure, Function, Role in Cell Comunication, A.J. van Bel and W.J.P. van Kestern, eds (Heidelberg, Germany: Spring-Verlag), pp. 129-148.

Peremyslov, V.V., Pan, Y.W. and Dolja V.V. (2004). Movement protein of a closterovirus is a type III integral transmembrane protein localized to the endoplasmic reticulum. J. Virol. 78, 3704-3709.

Prokhnevsky, A.I., Peremyslov, V.V., and Dolja, V.V. (2005). Actin cytoskeleton is involved in targeting of a viral Hsp70 homolog to the cell periphery. J. Virol. 79, 14421-14428.

Qu, F., Ren, T., and Morris, T.J. (2003). The coat protein of Turnip crinkle virus suppresses posttranscriptional gene silencing at an early initiation step. J. Virol. 77, 511-522. 
Rapp, M., Granseth, E., Seppällä, S., and von Heijne, G. (2006). Identification and evolution of dual-topology membrane proteins. Nat. Struct. Mol. Biol. 13, 112-116.

Reichel, C., and Beachy, R.N. (2000). Degradation of Tobacco mosaic virus movement protein by the $26 \mathrm{~S}$ proteasome. J. Virol. 74, 3330-3337.

Ritzenthaler, C., Nebenfuhr, A., Movafeghi, A., Stussi-Garaud, C., Behnia, L., Pimpl, P., Staehelin, L.A., and Robinson, D.G. (2002). Reevaluation of the effects of brefeldin A on plant cells using tobacco bright yellow 2 cells expressing Golgi-targeted green fluorescent protein and COPI antisera. Plant Cell 14, 237-261.

Ritzenthaler, C., and Hofman, C. (2007). Tubule guide movement of plant viruses. In: Viral Transport in Plants (Waigmann, E. and Heinlein, M., eds.). Springer-Verlag Berlin Heidelberg, pp. 63-83.

Riviere, C.J., and Rochon, D.M. (1990). Nucleotide sequence and genomic organization of Melon necrotic spot virus. J. Gen.Virol. 71, 1887-1896.

Robinson, D.G., Herranz, M.C., Bubeck, J., Pepperkok, R. and Ritzenthaler, C. (2007) Membrane dynamics in the early secretory pathway. Crit Rev Plant Sci. 26,199-225.

Sagi, G., Katz, A., Guenoune-Gelbart, D., and Epel, B.L. (2005). Class 1 reversibly glycosylated polypeptides are plasmodesmal-associated proteins delivered to plasmodesmata via the golgi apparatus. Plant Cell 17, 1788-800.

Sambrok, J., Fritsch, E.F., and Maniatis, T. (1998). Molecular cloning: A laboratory Manual. (Cold Spring Harbor, NY: Cold Spring Harbor Press).

Sanchez-Navarro, J.A., Miglino, R., Ragozzino, A., and Bol, J.F. (2001). Engineering of Alfalfa mosaic virus RNA 3 into an expression vector, Arch. Virol. 146, 923-939.

Sánchez-Navarro, J. A., Herranz, M. C. and Pallas, V. (2006) Cell-to-cell movement of Alfalfa mosaic virus can be mediated by the movement proteins of llar-, bromo-, cucumo-, tobamoand comoviruses, and does not require virion formation. Virology, 346, 66-73.

Sauri, A., Saksena, S., Salgado, J., Johnson, A.E., and Mingarro, I. (2005). Double-spanning plant viral movement protein integration into the endoplasmic reticulum membrane is signal recognition particle-dependent, translocon-mediated, and concerted. J Biol Chem 280, 25907-25912.

Stopar, D., Spruijt, R. B. and Hemminga, M. A. (2006). Anchoring mechanisms of membraneassociated M13 major coat protein. Chem. Phys. Lipids 141, 83-93.

Tse, Y.C., Lo, S.W., Hillmer, S., Dupree, P., and Jiang, L. (2006). Dynamic response of prevacuolar compartments to brefeldin a in plant cells. Plant Physiol.142, 1442-1459.

van Geest, M., and Lolkema, J.S. (2000). Membrane topology and insertion of membrane proteins: search for topogenic signals. Microbiol. Mol. Biol. Rev. 64, 13-33.

Vilar, M., Esteve, V., Pallas, V., Marcos, J.F., and Perez-Paya, E. (2001). Structural properties of carnation mottle virus p7 movement protein and its RNA-binding domain. J. Biol. Chem. 276, 18122-18129.

Vilar, M., Sauri, A., Marcos, J.F., Mingarro, I., and Perez-Paya, E. (2005). Transient structural 
ordering of the RNA-binding domain of Carnation mottle virus p7 movement protein modulates nucleic acid binding. Chembiochem 6, 1391-1396.

Vilar, M., Sauri, A., Monne, M., Marcos, J.F., von Heijne, G., Perez-Paya, E., and Mingarro, I. (2002). Insertion and topology of a plant viral movement protein in the endoplasmic reticulum membrane. J. Biol. Chem. 277, 23447-23452.

Voinnet, O., Lederer, C., and Baulcombe, D.C. (2000) A viral movement protein prevents spread of the gene silencing signal in Nicotiana benthamiana. Cell 103, 157-167.

von Heijne, G. (1992). Membrane-Protein Structure Prediction-Hydrophobicity Analysis and the Positive-Inside Rule. J. Mol. Biol. 225, 487-494.

von Heijne, G. (2006). Membrane-protein topology. Nat. Rev. Mol. Cell Biol. 7, 909-918.

Waigmann, E., Ueki, S., Trutnyeva, K., and Citovsky, V. (2004).The ins and outs of nondestructive cell-to-cell and systemic movement of plant viruses. Crit. Rev.Plant Sci. 23,195250.

Wolf, S., Deom, C. M., Beachy, R. N., and Lucas, W. J. (1989). Movement protein of Tobacco mosaic virus modifies plasmodesmatal size exclusion limit. Science 246, 377-379.

Wright, K. M., Wood, N.T., Roberts, A.G., Chapman, S., Boevink, P., MacKenzie, K.M., and Oparka, K.J. (2007). Targeting of TMV movement protein to plasmodesmata requires the actin/ER network: evidence from FRAP. Traffic 8, 21-31.

Yang, Y., Elamawi, R., Bubeck, J., Pepperkok, R., Ritzenthaler, C., and Robinson, D.G. (2005). Dynamics of COPII vesicles and the Golgi apparatus in cultured Nicotiana tabacum BY-2 cells provides evidence for transient association of Golgi stacks with endoplasmic reticulum exit sites. Plant Cell 17, 1513-1531.

Zambrysky, P., and Crawford, K. (2000). Plasmodesmata: Gatekeepers for cell-to-cell transport of developmental signals in plants. Annu. Rev. Cell Dev. Biol. 16, 393-417.

Zamyatnin, A.A., Solovyev, A.G., Bozhkov, P.V., Valkonen, J.P.T., Morozov, S.Y., and Savenkov, E.I. (2006). Assessment of the integral membrane protein topology in living cells. Plant J. 46, 145-154. 


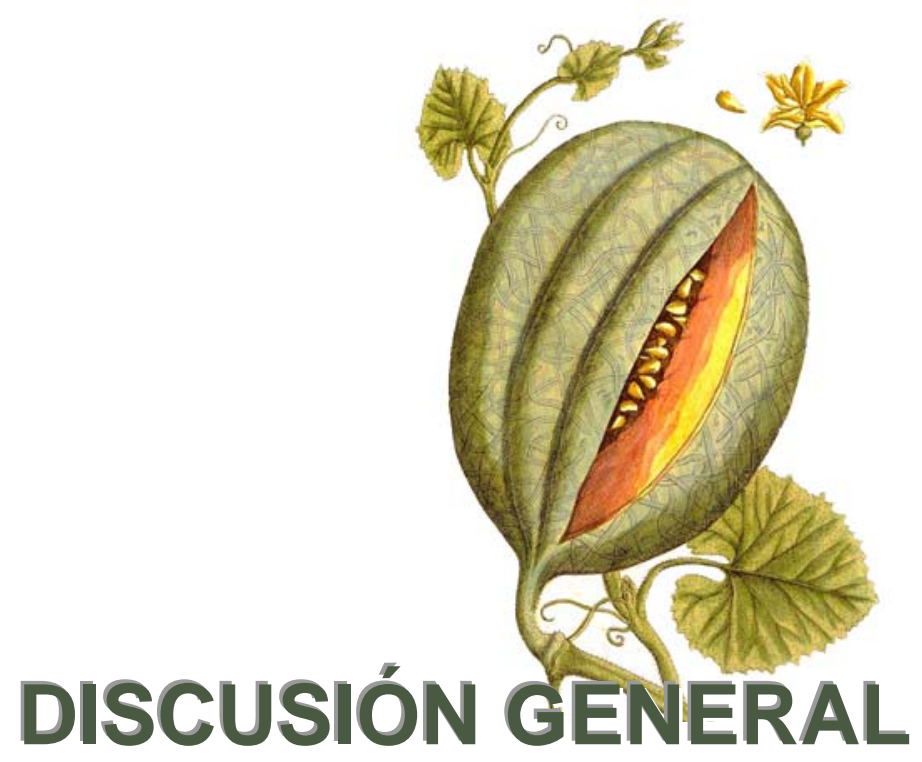




\section{DISCUSIÓN GENERAL}

La propagación de un determinado virus en una planta susceptible se inicia con la replicación del mismo en la célula inicialmente infectada. Un gran porcentaje de virus de plantas presentan genomas de RNA de polaridad positiva, por lo que, en estos casos, la infección requiere la síntesis de la RdRp viral. Tras replicarse, la progenie viral es transportada hacia las células vecinas a través de los plasmodesmos en un proceso que incluye los denominados movimientos intra- e intercelular. Esta fase del ciclo viral es dirigida en el citoplasma celular por las proteínas de movimiento (MPs) del virus junto con la maquinaria de transporte de macromoléculas de la célula huésped. Posteriormente, el virus alcanza las partes dístales de la planta mediante el movimiento sistémico para el cual es necesaria la invasión del sistema vascular que, en la mayoría de casos descritos, es dependiente de la proteína de la cápsida (CP). Además, el virus ha de ser capaz de evadir la respuesta de defensa del hospedador que limita, en muchos casos, el movimiento a corta y larga distancia del patógeno. Un mecanismo defensivo de la planta bien caracterizado es el silenciamiento génico de RNA y la forma más habitual de contrarrestarlo por parte de los virus es la expresión de factores proteicos que suprimen dicho mecanismo y que pueden actuar a diferentes niveles. Los virus, por tanto, codifican en sus genomas las proteínas implicadas en el desarrollo de las principales etapas de una infección viral y el estudio de los mecanismos implicados en cada una de ellas constituye la base para el desarrollo de nuevas estrategias de control de las virosis.

El género Carmovirus representa al menos 13 especies de virus de plantas que afectan a numerosas especies cultivadas en muchos de los casos con una gran repercusión económica. Estudios realizados in vivo con el virus del arrugamiento del nabo (TCV) sugieren la participación de un sistema de dos pequeñas MPs (Bloque de dos genes, DGB) en el movimiento de los Carmovirus. Por otro lado, estudios bioquímicos y estructurales con las proteínas homologas del Virus de moteado del clavel (CarMV) han llevado a proponer un modelo de movimiento para los Carmovirus en el que la DGBp1 sería el factor encargado de unir el RNA viral, mientras que la DGBp2, anclada a la membrana del RE, podría favorecer el transporte del complejo DGBp1-RNA hacia la periferia celular (Marcos et al., 1999; Vilar et al., 2001; Vilar et al., 2002). Debido a la sencillez estructural de estas proteínas, los Carmovirus constituyen un sistema idóneo para el estudio del movimiento de los virus de plantas.

En este trabajo se ha abordado el estudio de: i) la función de las proteínas codificadas en el genoma del MNSV, ii) las características bioquímicas y funcionales de las proteínas de movimiento (MPs) del MNSV, iii) el patrón de distribución subcelular de las MPs del MNSV. Los datos obtenidos han llevado a la formulación de un modelo de movimiento célula a célula para estos patógenos. 


\section{Análisis funcional de las proteínas codificadas por el genoma del Virus de las manchas necróticas del melón (MNSV).}

La obtención de clones de DNA de secuencias virales que tras su transcripción a las correspondientes secuencias de RNA mantengan la capacidad infecciosa del RNA viral del cual derivan ha constituido una herramienta imprescindible en el análisis de la estructura-función de los virus de plantas (Boyer y Haenni, 1994). En el presente trabajo, la secuencia genómica de un aislado natural del MNSV obtenido de plantas de melón (Cucumis melo cv galia) de cultivos de invernadero de Almería se ha clonado bajo el control del promotor de la RNA polimerasa T7. Esta construcción se ha denominado pMNSV(Al). Los RNAs transcritos a partir de este clon se inocularon mecánicamente sobre cotiledones de melón. Las plantas inoculadas reprodujeron la misma sintomatología observada en infecciones iniciadas con el RNA viral o con los viriones del aislado original: manchas redondeadas y cloróticas tanto en cotiledones como en hojas que con el tiempo llegan a necrosarse dando lugar al aspecto típico de cribado.

Al iniciar este estudio no se disponía de datos experimentales sobre la funcionalidad de las diferentes proteínas codificadas en el genoma del MNSV. Por tanto, el papel desempeñado por éstas en el ciclo vital del virus únicamente se podía inferir mediante la búsqueda de similitud en la secuencia de aminoácidos con otras proteínas virales cuya funcionalidad había sido investigada. Estos estudios habían sido realizados principalmente en miembros del género Tombusvirus pero solo para un Carmovirus, el TCV, se disponía de evidencias experimentales al respecto. Por este motivo, una vez comprobada la viabilidad del clon pMNSV(Al), esta herramienta molecular se utilizó para determinar el papel desempeñado por cada factor proteico del virus en las etapas del ciclo infeccioso. Para ello, se procedió a la obtención de una colección de mutantes sobre pMNSV(Al) en los que se bloqueó la síntesis individual de las proteínas virales mediante la utilización de técnicas convencionales de mutagénesis dirigida. Además, se realizaron las mismas modificaciones en los genes virales sobre una construcción quimérica de este clon viral, denominada pMNSV(Al)- $\Delta \mathrm{cp}$-GFP, en la que se sustituyó la ORF correspondiente a la proteína de cubierta por el gen de la proteína de fluorescencia verde (Green fluorescent protein, GFP). De esta forma, se pudo visualizar el avance de la infección a nivel local en la planta mediante la detección de la fluorescencia generada por la GFP. Puesto que la expresión de esta proteína fluorescente depende de la síntesis del sgRNA 2, la emisión de fluorescencia tan solo se observará si existe replicación viral. Los RNAs virales derivados de ambas colecciones de construcciones, se ensayaron in vivo sobre plantas de melón.

Trabajos previos habían puesto de manifiesto la existencia en la parte $5^{\prime}$ del genoma del MNSV de dos pautas de lectura abierta (ORF) separadas por un codón de parada débil, UAG, que dan lugar a una proteína de $29 \mathrm{kDa}$ y a otra de $89 \mathrm{kDa}$, consecuencia de la lectura a través del mismo (Riviere y Rochon, 1990). Para evitar la expresión individual de p29 o p89 se sustituyó el codón de parada interno por un triplete AUG (Met) o se introdujo un desplazamiento en la pauta de lectura inmediatamente después de la ORF de p29, 
respectivamente. El ensayo in vivo de ambas construcciones no ocasionó ningún tipo de sintomatología macroscopica, asimismo, no se detectaron RNAs virales ni expresión de la fluorescencia. Por tanto, la ausencia tanto de p29 como de p89 imposibilita la síntesis de nuevas moléculas de RNA viral. Así, estas dos proteínas deben ser esenciales en la replicación de MNSV y podrían considerarse como las RdRp de este virus. En este sentido, es probable que tanto p29 como p89 formen parte del complejo replicativo viral, tal y como se ha descrito para proteínas similares de virus relacionados como el TCV (Hacker et al., 1992; Rajendran et al., 2002) o el virus del enanismo ramificado del tomate (Tomato bushy stunt virus, TBSV) (Rajendran y Nagy, 2003; Rajendran y Nagy, 2004; Pogany et al., 2005).

Por otro lado, se ha descrito que el transporte célula a célula del TCV es controlado por un sistema de dos pequeñas proteínas de movimiento (MP) cuyas ORFs se sitúan en la región central del genoma (Hacker et al., 1992; Li et al., 1998; Chen et al., 2000). Aunque estas proteínas reciben un nombre específico según su peso molecular, forman el denominado Bloque de dos genes (Double gene block protein, DGBp) de los Carmovirus (Hull, 2002). Por este motivo, también se les designa de forma genérica como DGBp1 y DGBp2, según el orden 5'-3' en la secuencia viral. Cabe destacar que mientras que las ORFs de DGBp1 y DGBp2 de todos los Carmovirus caracterizados molecularmente poseen secuencias que solapan entre ellas en mayor o menor medida, esto no sucede en el MNSV. Por el contrario, ambos genes, cuyos productos se denominan en este caso p7A (DGBp1) y p7B (DGBp2), se encuentran separados por el codón débil de parada situado al final de la ORF de la p7A seguido de un triplete de Cys inmediatamente anterior al de la Met inicial de p7B. De esta forma, en el caso de evitarse la parada en la traducción de la p7A y al mantenerse la pauta de lectura abierta entre ambos genes, se podría sintetizar una proteína de fusión de aproximadamente 14 kDa que incluiría, en tamdem, la secuencia de aminoácidos completa de p7A y p7B (p14) (Riviere y Rochon, 1990). La existencia de esta proteína y su posible participación en el ciclo del virus ha sido materia de debate en los últimos años. Debido a esta peculiaridad, en el presente trabajo se estudió el papel desempeñado por las DGBps del MNSV en el movimiento viral y también la posible implicación funcional de la p14 en el proceso. Para ello, se realizaron construcciones con pérdida de función para la p7A y la p7B, así como una tercera en la que se eliminó el codón de parada que hay entre ambas ORFs para favorecer la síntesis de la p14. Los resultados de los bioensayos mostraron que en los tres casos no se observó la aparición de síntomas macroscópicos ni se pudieron detectar los RNAs virales, una situación idéntica a la observada en el caso de las RdRp. Sin embargo, aunque la inoculación de RNAs derivados de pMNSV(Al)- $\Delta$ cp-GFP generaron focos de infección multicelulares, la emisión de fluorescencia en estos tres mutantes quedó restringida a células individuales. Este último resultado sugiere que aunque el virus fue capaz de replicarse, la invasión viral no pudo avanzar más allá de la célula inicialmente infectada. Esta situación genera una acumulación muy reducida de RNAs virales que hace que no se puedan detectar mediante la metodología utilizada para este fin. 
Como cabría esperar, la ausencia de p7A o p7B resultó ser crítica para el movimiento local del virus que tampoco pudo realizarse si ambas proteínas estaban presentes en forma de una fusión (p14). Sin embargo, tanto la p7A como la p7B actuando en trans, pudieron restablecer parcialmente el movimiento célula a célula de los correspondientes RNAs virales deficientes en cada una de estas proteínas. Por el contrario, en experimentos de complementación similares se observó que la p14 no fue capaz de promover el movimiento local del virus incluso en presencia de la p7A o la p7B. La p14 tampoco pudo ser detectada con anticuerpos específicos, diseñados contra un péptido derivado de p7A, durante una infección generada mediante inoculación de viriones del MNSV. Además, en el caso de que esta proteína se acumulase a niveles situados por debajo del umbral de detección de la técnica utilizada no estaría clara su funcionalidad dado que, de manera consistente con los resultados obtenidos en este trabajo, existe un aislado natural del MNSV, denominado MNSV $\alpha 5$, capaz de infectar sistémicamente su huésped pero que posee un codón de parada fuerte entre las ORF de ambas proteínas de movimiento (Díaz et al., 2003). En estas condiciones, la síntesis de la proteína de fusión es prácticamente improbable. Por tanto, la p7A y la p7B formarían un sistema de proteínas en el que serían necesarias y suficientes para promover el movimiento célula a célula del MNSV y se pueden considerar como las proteínas de movimiento de este virus.

Por último, estudios previos pusieron de manifiesto que la p42 del MNSV es la proteína estructural responsable de la encapsidación del virión (Riviere et al., 1989; Riviere y Rochon, 1990) y, por tanto, es la CP del virus. Mediante ensayos in vivo con RNAs derivados de construcciones mutantes en las que o bien se bloqueó la síntesis de la p42, se eliminó totalmente del genoma la ORF correspondiente (pMNSV(Al)- $\Delta \mathrm{cp}$ ) o, como se ha adelantado, se sustituyó por el gen de la GFP (pMNSV(Al)- $\Delta$ cp-GFP), se observó que esta proteína no era requerida en el movimiento célula a célula puesto que se detectaron RNAs virales y focos de infección multicelulares en los cotiledones inoculados. No obstante, éstos últimos presentaron un tamaño más reducido que en presencia de la p42. Por el contrario, en ninguno de los tres casos se recuperaron RNAs virales o se observó emisión de fluorescencia en partes distales al punto de inoculación o en el sistema vascular, indicando que esta proteína es necesaria para la invasión sistémica de la planta por parte del virus. Estos resultados sugieren que el MNSV es capaz de moverse célula a célula en forma de un complejo ribonucleoproteico sin necesidad de generar partículas víricas completas. No obstante, la incapacidad del MNSV de moverse sistémicamente en ausencia de la CP indica que la entrada del virus al sistema vascular, que ocurre a través del floema (Gosalvez et al., enviado), puede requerir la encapsidación del genoma en viriones. No se puede descartar, sin embargo, que la CP formara parte de un complejo ribonucleoproteico, diferente al implicado en el transporte local, capaz de desplazarse por el floema al resto de la planta. Por otro lado, la inoculación de los RNAs derivados de la construcción deficiente en la síntesis de p42 provocó una sintomatología menos severa en los cotiledones inoculados en tanto que las típicas manchas cloróticas eran más pequeñas, en 
proporción con el tamaño reducido de los focos de infección, y además, no llegaron nunca a necrosarse. Además, la eliminación de la secuencia de nucleótidos del gen de la CP en pMNSV(Al)- $\Delta c p$ o su substitución por una secuencia no viral en el caso de pMNSV(Al)- $\Delta c p-$ GFP provocó la desaparición total de los mismos. Por tanto, la p42 es capaz de modular la sintomatología en infecciones locales, siendo ésta la responsable del aumento del tamaño y la intensidad de los síntomas. El efecto positivo de p42 sobre el avance local de la infección fue similar al obtenido cuando la infección con RNAs derivados de pMNSV(Al)- $\Delta$ cp-GFP se complementó con un supresor viral del silenciamiento génico de RNA denominado HC-Pro (Helper component proteinase de Potivirus). En este punto cabe destacar que esta actividad se ha descrito ampliamente para diferentes proteínas de virus no relacionados filogenéticamente (Qu y Morris, 2005). Se trata de una función muy conservada por lo que aparentemente desempeña un importante papel en la biología de los virus de plantas. En este contexto, además de la proteína HC-Pro, son ejemplos de proteínas virales con actividad supresora del PTGS la p25 del Virus $X$ de la patata (PVX) (Voinnet et al., 2000), la p19 de Tombusvirus (Silhavy et al., 2002), la 2b del Virus del mosaico del pepino (CMV) (Ryabov et al., 2004b) o la CP del Virus del arrugamiento del nabo (TCV) (Qu et al., 2003; Thomas et al., 2003). En lo que concierne a la actividad supresora del silenciamiento génico postranscripcional de las proteínas del MNSV, se ha observado que tanto la p42 como la p7B actúan como supresores del PTGS en experimentos de expresión transitoria sobre la línea $16 \mathrm{c}$ de plantas transgénicas de $N$. benthamiana capaces de expresar la GFP (Ruiz et al., 1998). Sin embargo, lo hacen con una eficiencia 10 veces inferior a la obtenida con supresores como HC-Pro o 2b. Así pues, la participación de p42 promoviendo el transporte intercelular probablemente sea una consecuencia indirecta de contrarrestar los mecanismos de defensa del huésped y por tanto, no exista una implicación directa de la p42 en el mecanismo molecular encargado del transporte de los genomas virales. Se ha descrito esta función para la proteína p25 de PVX, la TGBp1 del bloque de tres genes (TGB) de Potexvirus (Voinnet et al., 2000; Lough et al., 2001) que, al igual que p7B (DGBp1), está a su vez implicada en el movimiento célula a célula del virus. Estos últimos datos sugieren que los factores virales que controlan el movimiento intra- e intercelular pueden tener a su vez actividad de supresión del PTGS (Verchot-Lubicz, 2005), aunque los estudios realizados hasta ahora no permiten determinar la etapa exacta del silenciamiento de RNA que se vería afectada por estas proteínas del MNSV.

\section{Las características bioquímicas y funcionales de las proteínas del MNSV, p7A y p7B, y su implicación en el movimiento intra e intercelular.}

Los virus de plantas codifican en sus genomas entre una y cinco proteínas responsables del movimiento viral de forma directa (Carrington et al., 1996; Lazarowitz y Beachy, 1999; Lucas, 2006; Waigmann et al., 2004). A estas diferencias en cuanto número hay que añadir una gran variabilidad de tamaño, estructura y poca similitud de secuencia de aminoácidos. Sin 
embargo, las MPs virales presentan propiedades comunes entre las que destacan la capacidad de formación de complejos con el RNA (Citovsky et al., 1990), la interacción con factores proteicos del huésped y/o compartimentos celulares (Curin et al., 2007; Lucas, 2006; Taliansky, 2006; Lee et al., 2005; Morozov y Solovyev, 2003) y la modificación del tamaño de exclusión molecular de los plasmodesmos (Ding et al., 1995; Lucas et al., 1995). Por tanto, es razonable pensar que estas funciones residan en estructuras comunes que sí se aprecian a nivel secundario o terciario.

A su vez, la comparación de las estructuras primarias de las proteínas del DGB de los Carmovirus muestra una baja simillitud de secuencia entre ellas aunque existe una gran conservación de los elementos de estructura secundaria que se observan mediante el uso de programas informáticos de predicción. Estos datos sugieren que la función desarrollada por las proteínas de movimiento de los Carmovirus debe atribuirse principalmente a las propiedades físicas y químicas de los residuos de aminoácidos por sí mismos o al plegamiento secundario del esqueleto peptídico, más que a la estructura primaria.

Por un lado, la p7A fue capaz de unir preferentemente RNA de simple cadena de forma cooperativa y sin especificidad de secuencia aparente. El valor estimado de la constante de disociación (Kd) del complejo formado entre la p7A y el RNA es del orden de $\mu \mathrm{M}$, por lo que se encuentra en el rango de los valores calculados para la p7 (DGBp1) del CarMV (Marcos et al., 1999; Vilar et al., 2001) así como de los de otras proteínas virales de unión al RNA no específicas de secuencia (Burd y Dreyfuss, 1994; Pata et al., 1995; Darós y Carrington, 1997; Herranz y Pallás, 2004). Los ensayos Nothwestern de p7A y de construcciones de la misma en las que se eliminó el dominio $\mathrm{N}$-terminal $(\mathrm{Nt})$, la region central o el extremo $\mathrm{C}$-terminal $(\mathrm{Ct})$, revelan que todas las regiones de la proteína participan en la unión al RNA, aunque es el dominio central, definido entre las posiciones 23 y 44 , el de mayor implicación en esta interacción. Asimismo, se corroboró la funcionalidad de dicha región utilizando un péptido sintético, equivalente en estructura primaria y secundaria ( $\alpha$-hélice) a la misma, en ensayos de unión a RNA. Sin embargo, en este caso, el valor estimado de la Kd fue de $9 \mathrm{mM}$, un orden de magnitud superior al de la proteína entera. Este resultado indica que aunque este dominio es capaz de unir el RNA por si solo, el proceso es menos eficiente que en el contexto de la proteína entera de acuerdo con los resultados obtenidos con los ensayos Northwestern. Por otro lado, el papel de los residuos básicos en la unión al RNA se ha descrito tanto para las MPs de virus pertenecientes al mismo género, como es el caso de la p7 del CarMV (Marcos et al., 1999; Vilar et al., 2001), así como de virus no relacionados, por ejemplo la TGBp1 de los Potexvirus (Morozov y Solovyev, 2003) o las proteínas de la Superfamilia 30K (Citovsky et al., 1992; Herranz y Pallás, 2004). En todos estos casos, la capacidad de unión queda restringida al dominio RBD (RNA binding domain), rico en aminoácidos básicos (Marcos et al., 1999; Vilar et al., 2001: Herranz y Pallás, 2004). Sin embargo, como se ha mencionado anteriormente, la molécula entera de la p7A se encuentra implicada en esta interacción con el RNA por lo que no 
se pudo definir un dominio RBD concreto. Este resultado podría ser consecuencia de que la p7A, a diferencia de otras proteinas de Carmovirus descritas, tiene sus aminoácidos cargados positivamente distribuidos a lo largo de toda su secuencia.

El grado de implicación de los elementos de estructura primaria y secundaria de la p7A en el movimiento célula a célula del virus se estudió mediante el ensayo in vivo de una nueva colección de construcciones mutantes del clon pMNSV(Al)- $\Delta$ cp-GFP. En este contexto, se estudió la relevancia de los residuos cargados positivamente que determinan la capacidad de unir ácidos nucleicos de la p7A, la estructura secundaria en $\alpha$-hélice de la región central y el motivo conservado FNF del extremo $\mathrm{Ct}$. De este modo, se ha observado que el movimiento del virus no es permisivo ni a cambios en los aminoácidos básicos, ni en la estructura secundaria del dominio central, pero sí en los extremos $\mathrm{Nt}$ y $\mathrm{Ct}$, aunque el movimiento local se ve reducido en mayor o menor medida. En este contexto, la cinética de unión a RNA de construcciones mutantes de la p7A muestra una correlación entre la capacidad de unir RNA y el movimiento célula a célula del virus. Así, los mutantes, ya sean de estructura o carga, en la región central de p7A dejan de unir al RNA. Estos datos son similares a los observados para el RBD de la MP del virus de los anillos necróticos de los Prunus (Prunus necrotic ringspot virus, PNRSV), donde se muestra que el movimiento célula a célula del virus es condicionado por la capacidad de unión a RNA de la misma (Herranz y Pallás, 2004; Herranz et al., 2005). Por otro lado, el movimiento del MNSV se bloquea cuando se sustituyen los residuos aromáticos del extremo Ct, muy conservados entre las DGBp1 del género Carmovirus. Este efecto podría deberse a la interacción entre las cadenas laterales de los mismos y las bases del RNA (Drapper, 1999; Jones et al., 2001). Sin embargo, el mutante es capaz de unir al RNA aunque con una constante de disociación mayor. De este modo, es probable que esta diferencia entre Kd sea suficiente para impedir el movimiento pero, por otra parte, el motivo FNF podría participar en la estabilidad de la proteína dado que se ha descrito la implicación de residuos aromáticos en interacciones terciarias dentro de la misma proteína o entre moléculas diferentes ( $\mathrm{Ma}$ et al., 2003; Rajamani et al., 2004). Así, el bloqueo del movimiento célula a célula para el mutante FNF de la p7A podría deberse a la dificultad para establecer interacciones con otros factores proteicos, ya sean virales o del huésped, esenciales para el movimiento. De este modo, el extremo Nt, mediante los residuos básicos presentes en esta región y el extremo $\mathrm{Ct}$, con menor carga positiva pero con una estructura secundaria en $\beta$-hoja plegada podrían modular la interacción con el RNA que se realizaría preferentemente por mediación de los residuos básicos y la estructura secundaria en $\alpha$-hélice de la región central de forma semejante a la descrita para la p7 del CarMV (Vilar et al., 2005). Esta interacción sería esencial para el movimiento local del MNSV.

Por otro lado, la p7B (DGBp2) del MNSV presenta un único dominio transmembrana (Transmembrane domain, TMD) a diferencia de la p9 (DGBp2) del CarMV (Vilar et al., 2002). La comparación de las secuencias de las DGBp2 de los Carmovirus claramente revela la 
existencia de 2 grupos de especies diferentes según tengan uno o dos TMD que estarían representados por el MNSV o CarMV, respectivamente. La p7B es capaz de insertarse, en un sistema de transcripción/traducción in vitro, en la bicapa lipídica de microsomas derivados del $\mathrm{RE}$ de células de páncreas canino. De acuerdo con este resultado, en el fraccionamiento subcelular de tejidos de $N$. benthamiana que expresan transitoriamente la p7B, ésta se detectó en la fracción insoluble que incluye preferentemente compartimentos membranosos de la célula. Además, en estos ensayos, la p7B se recuperó mayoritariamente en forma de homodímeros en las membranas celulares en las que se inserta, como ocurre con la proteína de movimiento p6 de Closterovirus (Peremyslov et al., 2004). Tras el tratamiento in vitro con el agente reductor DTT, las formas diméricas de la p7B desaparecen dando lugar exclusivamente a la forma monomérica de la proteína. De forma similar, la sustitución de los únicos tres residuos de Cys, localizados en el extremo Nt de la molécula, por Ala provocó el mismo resultado. Por tanto, la formación de los dímeros de p7B debe de ser mediada por la creación de puentes disulfuro, un enlace químico covalente, entre los grupos tiol de las cadenas laterales de estos residuos de Cys. Además, se ha comprobado que la sustitución de las tres Cys por Ala provoca una drástica disminución del movimiento célula a célula del virus por lo que los homodímeros de p7B probablemente constituyen la forma funcional de esta molécula. Es importante destacar aquí que la disulfuro isomerasa, enzima capaz de catalizar la formación de los puentes disulfuro entre residuos de cisteína, es exclusiva del lúmen del RE (Frand et al., 2000). Teniendo en cuenta esta observación, para poder formar estos dímeros esenciales en el movimiento, la p7B debería adoptar in vivo una orientación Nt luminar/Ct citosólica puesto que, como se ha mencionado anteriormente, no existen más residuos de Cys en la molécula que los tres situados en el extremo Nt. Sin embargo, los datos obtenidos por ensayos de complementación bimolecular de la fluorescencia (BiFC) en plantas de $N$. benthamiana indicaron que p7B es capaz de insertarse en la membrana del RE adoptando una topología dual con dos orientaciones opuestas. Por otro lado, se ha demostrado que los residuos con cargas positivas impiden la translocación, del dominio donde se sitúan, a través de la membrana. Por tanto, el dominio citoplasmático de estas proteínas presenta más cargas positivas (la regla positivo-dentro) (von Heijne, 1992). En este sentido, como cabría esperar de las proteínas que presentan una topología dual, la p7B posee solo dos residuos básicos (R5 y K49) cada uno situado a ambos lados del fragmento transmembrana. Esta situación contrasta con la encontrada en la p6 del BYV, una proteína de tipo I donde el extremo Ct citosólico presenta tres cargas positivas frente a una única en el extremo Nt luminal. A pesar de ello, la introducción de tres residuos de Lys en el extremo Nt de p7B (entre las posiciones L32 y S33) no provocó un cambio aparente en su topología dual. Sin embargo, existen otros casos descritos como ocurre con el canal politópico que constituye la ductina (Dunlop et al., 1995). Interesantemente, la posibilidad de que p7B adopte una doble topología en su inserción en membrana le asemeja a las DGBp2 de Carmovirus del tipo CarMV. En este contexto, la p9 es capaz de insertarse en la membrana del RE mediante sus dos TMD exponiendo los extremos 
Nt y Ct al lado citosólico (Vilar et al., 2002; Sauri et al., 2005). En un trabajo reciente realizado con proteínas de membrana se ha demostrado que tras una duplicación génica se pueden generar proteínas homólogas que adoptan una topología opuesta en su inserción a la membrana debido a la redistribución de sus cargas. De este modo, la fusión entre los genes duplicados puede dar lugar a una única proteína con dos fragmentos transmembrana opuestos (Rapp et al., 2006). De esta forma, las DGBp2 del MNSV y del CarMV podrían representar pasos evolutivos diferentes del género Carmovirus.

Asimismo, mediante el ensayo in vivo de RNAs derivados de construcciones mutantes del clon pMNSV(Al)- $\Delta c p-G F P$, en las que se ha sustituido diferentes aminoácidos de la secuencia de $\mathrm{p} 7 \mathrm{~B}$, se ha podido determinar la importancia de aquellas características que modulan la correcta inserción y la topología de una proteína en la bicapa lipídica en el movimiento célula a célula del MNSV. En concreto, se ha estudiado la posible relevancia de la hidrofobicidad del fragmento transmembrana, además de los residuos aromáticos y cargados a ambos lados del dominio hidrofóbico que condicionan la estabilidad de la inserción y la orientación en la membrana, respectivamente (revisados en von Heijne, 2006). De esta forma, se ha observado que al disminuir la hidrofobicidad del TMD por sustitución de aminoácidos hidrofóbicos se obtiene una drástica reducción del movimiento del virus, delimitándose un umbral de hidrofobicidad a partir del cual éste deja de moverse ( $<5 \mathrm{Kcal} / \mathrm{mol})$. Del mismo modo, los residuos cargados alrededor del TMD y la estructura en $\alpha$-hélice de éste condicionan el movimiento. Todos estos resultados muestran la relevancia de la correcta inserción en la membrana de la p7B para que se dé el movimiento del MNSV. Sin embargo, la sustitución de los residuos de Tyr de alrededor del TMD favorece el movimiento, efecto que podría deberse a que las cadenas laterales de los residuos aromáticos, tan voluminosas, podrían dificultar la movilidad de la p7B entre las membranas del interior celular y con ello el movimiento del virus.

De acuerdo con el modelo propuesto para el CarMV para el movimiento intra e intercelular de los Carmovirus (Marcos et al., 1999; Vilar et al., 2001; Vilar et al., 2002), la p7A podría ser la encargada de interaccionar con el genoma del virus mientras que la p7B, asociada a las membranas del interior de la célula, podría favorecer el transporte del complejo p7A-RNA hacia la periferia celular. Asimismo, dado que la unión MP-RNA no es específica de secuencia, debe existir una compartimentación que facilite la accesibilidad del complejo replicativo a la p7A, favoreciendo así el transporte del RNA viral. Así, la p7B, debido a su carácter hidrofóbico y su capacidad de inserción a membrana, podría encargarse del marcaje específico de orgánulos celulares. En este sentido, para un sistema proteico no homólogo como el del TGB de los Potexvirus, se ha descrito a las proteínas TGBp2 y TGBp3 como proteínas integrales de membrana asociadas al RE (Morozov et al., 2003). La TGBp3 dirige a la TGBp2 y la TGBp1, proteína capaz de unir ácidos nucleicos, hacia el plasmodesmo (PD) en el movimiento célula a célula (Solovyev et al., 2000; Zamyatnin et al., 2004; Haupt et al., 2005). 
En base a estos antecedentes, la DGBp2 de los Carmovirus podría actuar como la TGBp3 de Potexvirus y dirigir al complejo DGBp1-RNA durante el movimiento intracelular.

\section{La distribución temporal y espacial a nivel subcelular de las proteínas de movimiento del MNSV, p7A y p7B, sugiere una ruta para su tráfico intracelular.}

Los resultados obtenidos in vivo mediante la expresión transitoria en $N$. benthamiana de la proteína recombinante GFP-p7B muestran una variación espacio-temporal de la distribución subcelular de la misma. A tiempos cortos de la expresión, la p7B co-localiza con la red del RE, mientras que posteriormente forma unas estructuras corpusculares que colocalizan con los dictiosomas del aparato de Golgi. Además, dichas partículas se mueven en el interior de la célula a través del citoesqueleto de actina/miosina con velocidad y trayectoria similares a la de este orgánulo. Por último, a tiempos de expresión más largos, la GFP-p7B se localiza en los PD celulares. Por otro lado, el patrón de localización subcelular de la p7B se ve modificado tras el tratamiento con Brefeldina $A$, una droga que inhibe la ruta de secreción afectando al transporte entre el RE y el aparato de Golgi. En este caso, la p7B aparece formando unas estructuras aberrantes que marcan el RE y que son características del colapso del aparato de Golgi provocado por la droga (Ritzenthaler et al., 2002). Además, como consecuencia de dicho tratamiento se inhibe el marcaje de los plasmodesmos (PD). Todo esto sugiere una ruta intracelular de movimiento para la p7B del MNSV en la que el aparato de Golgi actuaría como intermediario en la translocación de la proteína desde el RE al PD. A este respecto, la colocalización de las proteínas de movimiento virales con la red del RE así como con los PD ha sido descrita en trabajos realizados con la p6 de los Closterovirus (Peremyslov et al., 2004), la MP del TMV (Atkins et al., 1991) o la TGBp2 del PVX (Mitra et al., 2003), entre otras. Sin embargo, los resultados presentados aquí muestran la primera evidencia de una interacción directa con el aparato de Golgi de una proteína de movimiento de virus de plantas. En consecuencia, éstos claramente sugieren a una posible nueva ruta intracelular de movimiento viral. En paralelo, estudios recientes han puesto de manifiesto el transporte intracelular a través del aparato de Golgi de una proteína asociada a plasmodesmos de A. thaliana, la proteína RGP2 (Reversibly glicosilated polipeptide 2) (Sagi et al., 2005), mostrando la misma ruta hacia el PD pero para una proteína no viral. Sin embargo, en el caso de RGP2, esta proteína no se observa en el RE ni en expresiones tempranas, ni tras el tratamiento con BrA, como ocurre con p7B y en lugar de ello se observa su distribución citoplasmática (Sagi et al., 2005; Drakakaki et al., 2006). Este dato puede ser reflejo de las diferencias en cuanto a asociación a membrana entre p7B y RGP2, lo que a su vez puede determinar el punto de entrada de cada proteína a la ruta de secreción. Así, se sabe que las proteínas integrales del sistema de endomembranas sintetizadas de novo entran en la ruta biosintética-secretora cuando atraviesan la membrana del RE desde el citosol y tras ello pueden pasar a la red del cis Golgi (van Geest y Lolkema, 2000). Dado que las RGP2 son proteínas solubles asociadas al lado citoplasmático de las membranas del aparato de Golgi y no proteínas integrales de membrana, en este caso podrían 
ser directamente dirigidas desde el citosol al aparato de Golgi sin la implicación del RE. Por último, la fusión de GFP al extremo Ct de la p7B bloquea su salida del RE, lo que puede ser consecuencia del bloqueo de factores que dirigen su salida desde el mismo al aparato de Golgi. Sin embargo, en el extremo Ct de p7B no se halla ningún motivo de los hasta ahora definidos como implicados en el tráfico entre el RE y el aparato de Golgi de proteínas transmembrana. Por tanto, se necesitan investigaciones futuras para definir la posible secuencia señal de la ruta de la p7B.

En paralelo a los resultados anteriores se ha estudiado la localización subcelular de mutantes de la p7B, estableciéndose una relación funcional directa entre la distribución de la misma y el movimiento del virus. Por un lado, la reducción en la hidrofobicidad de p7B da lugar a la deslocalización de ésta, lo que resulta en la inhibición del movimiento del virus. De esta forma, los mutantes $L_{17} A L_{18} A l_{19} A, L_{20} A_{21} A I_{22} A, F_{27} A l_{29} A$ que representan los perfiles de hidrofobicidad más bajos de la p7B, se insertan en el RE y forma partículas fluorescentes y sin embargo, no colocalizan ni con el aparato de Golgi ni con los PD, lo que resulta en un bloqueo del movimiento del virus. Por otro lado, un resultado similar se observa cuando se altera el balance de carga neutro alrededor del TMD con los mutantes $D_{7} R$ y $D_{44} R$, y con ello la inserción de la proteína en el aparato de Golgi y los PD. Por otra parte, si se modifica la estructura en $\alpha$-hélice del TMD de la p7B en el mutante $S_{23} P$, la proteína colocaliza con los dictiosomas del aparato de Golgi pero no con los PD, quedando también bloqueado el movimiento. Trabajos previos han puesto de manifiesto que la localización en PD de mutantes de la MP del CMV repercute directamente en el movimiento de dichos mutantes (Cantó y Palukaitis, 2005). Sin embargo, el mutante $\mathrm{C}_{3} \mathrm{GC}_{4} \mathrm{GC}_{6} \mathrm{G}$ se localiza tanto en las cisternas del aparato de Golgi como en los PD aunque prácticamente no se mueve. Este resultado refuerza la hipótesis de que los homodímeros de p7B constituyen una forma funcional de esta proteína en el movimiento del virus. Por último, la sustitución de los residuos de Tyr en los mutantes $Y_{28} A, Y_{13} A$ y $Y_{39} A$ no modifica la distribución en el aparato de Golgi de la p7B y, en los dos primeros casos, el movimiento del virus es incluso más eficiente. Como ya se ha indicado antes, los residuos aromáticos pueden estar implicados en la posición y el anclaje del TMD. Sin embargo, aquí la posición de la p7B en la membrana no parece ser importante y la falta de anclaje podría actuar facilitando el intercambio de la misma entre las membranas del interior celular, lo que se traduce en un mayor avance de la infección.

A su vez, la p7A del MNSV se detectó asociada a los dictiosomas del aparato de Golgi, a la periferia celular y plasmodemos mediante la utilización de proteínas fluorescentes recombinantes que se expresaron transitoriamente con el uso de varias estrategias: la expresión transitoria mediada por agroinfeccion o por infección del propio virus y ensayos de complementación bimolecular de la fluorescencia. Además, su sobreexpresión dió lugar a un patrón de distribución citoplasmático de la misma. Como se ha comentado antes, la p7A es una proteína hidrofílica, por tanto, su localización en el aparato de Golgi posiblemente se deba a la 
interacción con una o varias proteínas asociadas a las membranas de este orgánulo. A su vez, la distribución citoplasmática observada de la p7A, por sobre expresión, podría deberse a la saturación de los sitios de unión de las mismas. En este contexto, dado que la p7B se integra en las membranas del aparato de Golgi, cabría pensar que ésta podría ser el factor que facilitase la localización de la p7A en este orgánulo. Sin embrago, la distribución de p7A en las vesículas del aparato de Golgi se observa incluso en ausencia de la proteína viral asociada a membrana o de otros factores del MNSV. Por ello, la p7A debe asociarse a algún factor del huésped presente en estas membranas. Recientes investigaciones han puesto de manifiesto la asociación de la proteína p8 del TCV, la equivalente de la p7A, con la proteína Atp8 de A. thaliana (Lin y Heaton., 2001). No obstante, a diferencia de p7A, la p8 se localiza en el núcleo mediante una secuencia señal de localización nucleolar (NLS) (Cohen et al., 2000b) aunque esta localización parece no estar implicada en el movimiento célula a célula del virus (Cohen et al., 2000a). Asimismo, recientemente se han descrito interacciones entre proteínas transmembrana del aparato de Golgi y algunos virus animales, aunque no se ha determinado la función de dicha interacción (Compton y Behrend, 2006). Además, los resultados de p7A se asemejan a los obtenidos con algunas golginas solubles asociadas de forma periférica a la membrana del aparato de Golgi a través de su dominio GRIP (Yoshino et al., 2003; Latijnhouwers et al., 2005; Stefano et al., 2006). Este dominio se une a la proteína soluble ARF1 y ésta a su vez se localiza en las membranas de la red del trans Golgi mediante una cascada de señalización que implican a la ARL3p y a una proteína integral de éstas (Liu et al., 2006). Asimismo, se ha observado que la sobreexpresión del dominio GRIP fusionado a la GFP en células HeLa y en hojas de $N$. tabacum da lugar a la distribución citoplasmática de la fluorescencia, enmascarando los dictiosomas del aparato de Golgi, resultado que, como se ha mencionado anteriormente, es probablemente consecuencia de la saturación de los sitios de unión (Latijnhouwers et al., 2005; Yoshino et al., 2003). En este escenario, se necesitan estudios adicionales para la identificación de los factores del huésped implicados en la localización de la p7A en Golgi así como su repercusión sobre el movimiento del virus.

\section{Modelo de movimiento célula a célula para Carmovirus.}

El avance local de la infección viral producida por la inoculación de RNAs transcritos del clon pMNSV(Al)- $\triangle \mathrm{cp}$-GFP es susceptible a la presencia de Brefeldina $A$, droga que como se ha mencionado anteriormente inhibe la ruta secretora actuando directamente sobre el transporte entre el RE y el aparato de Golgi mediado por las vesículas COPI y COPII (Ritzenthaler et al., 2002). Así, la propagación del foco de infección se vió reducida en presencia de esta droga en el tejido infectado, sin que ello afecte a los niveles de replicación del virus. Esta observación, por tanto, claramente sugiere la funcionalidad del aparato de Golgi en el movimiento intracelular del MNSV (Figura 18). 
La distribución subcelular de las MPs ha llevado a establecer modelos de movimiento intracelular para los virus de plantas. Así, trabajos previos han puesto de manifiesto que el movimiento intracelular de los mismos ocurre a través de la maquinaria celular de transporte de macromoléculas que el virus aprovecha en su camino hacia el PD. Por ejemplo, la MP del TMV se desplaza a través de la red cortical del RE y el citoesqueleto de actina, mientras que las proteínas del TGB lo hacen favoreciéndose de las vesículas de secreción y de la ruta endocítica (revisado en Ritzenthaler y Hofman, 2007 y Waigmann et al., 2007).

De los resultados obtenidos en el presente trabajo cabe deducir que el MNSV no seguiría ninguna de las rutas propuestas para otros virus. Nosotros proponemos un nuevo modelo de movimiento intracelular para el MNSV (Figura 18), según el cual la proteína p7B se insertaría inicialmente en las membranas del RE y sería exportada al aparato de Golgi siguiendo, probablemente, la ruta biosintética-secretora celular de proteínas transmembrana sintetizadas de novo. Asimismo, la p7A con el gRNA unido, se asociaría a la cara citoplasmática de las membranas del aparato de Golgi por interacción con otros factores del huésped presentes en este orgánulo. Por tanto, la p7A unida a la cara citoplasmática del aparato de Golgi movería el genoma de MNSV y a su vez la p7B se transportaría integrada en las membranas del mismo hasta el PD. En este contexto, la función de p7B podría darse a nivel del PD. Así, ésta podría actuar marcando la diana del complejo ribonucleoproteíco, p7AgRNA, como se ha descrito con las proteínas del TGB. Como se ha mencionado anteriormente, en este caso la proteína de movimiento encargada de unir RNA, la TGBp1, se distribuye uniformemente en el interior celular a menos que sea expresada simultáneamente con las proteínas asociadas a membrana, TGBp2 y TGBp3, en cuyo caso dirigen a TGBp1 al PD (Zamyatnin et al., 2004). Asimismo, la p7B podría actuar modificando el SEL del PD permitiendo así al complejo de movimiento alcanzar la célula adyacente, capacidad que se ha demostrado para las MPs de la Superfamilia 30K aunque, en este caso, esta capacidad la desarrollaría la misma proteína que transporta el gRNA. Sin embargo, dado que el sistema del DGB se compone de dos miembros, la p7B podría ser la encargada de desarrollar esta función. 


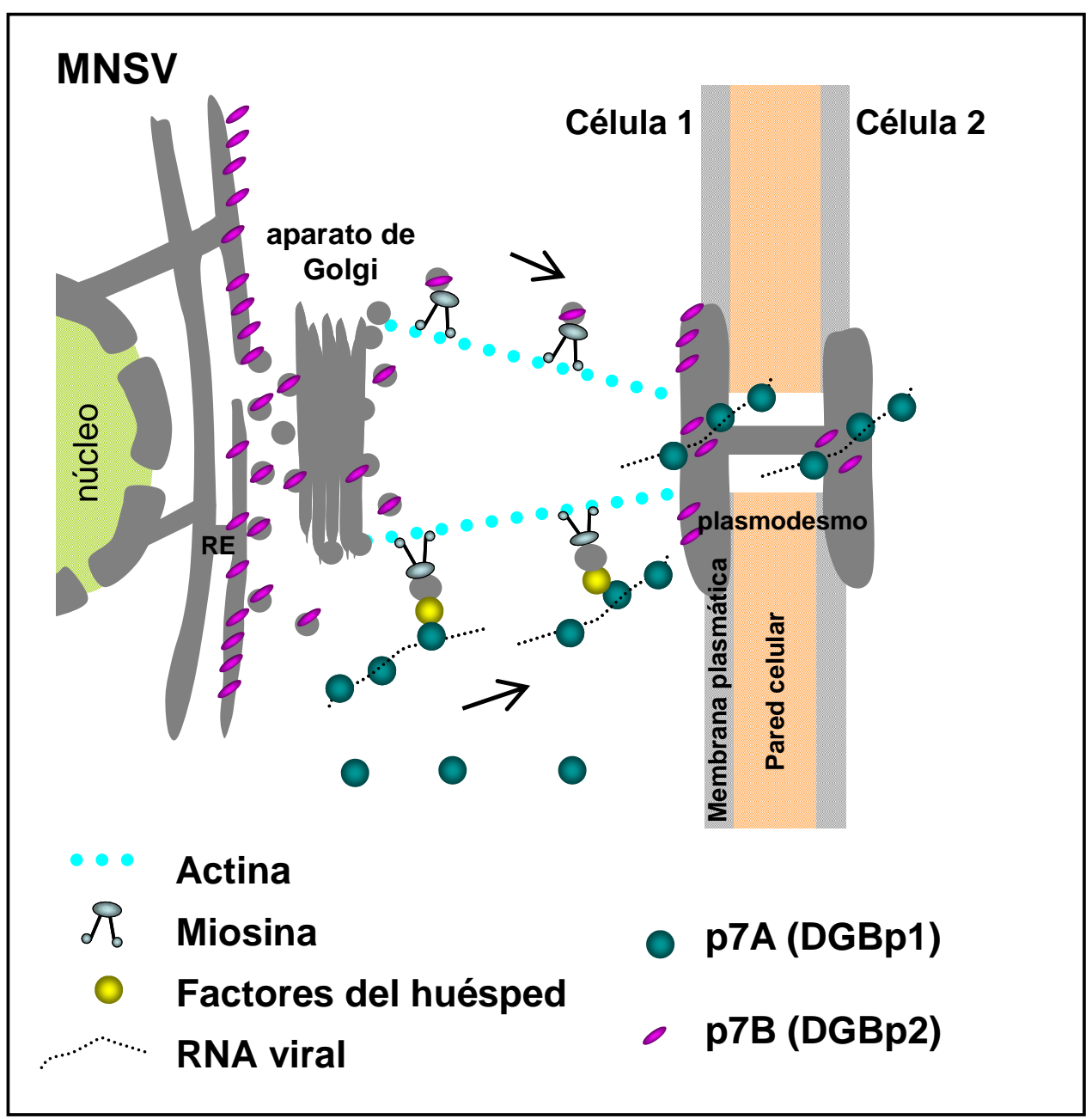

Figura 18. Posibles rutas intracelulares seguidas por proteínas virales del MNSV, bloque de dos genes (DGB) en su camino a la periferia celular. Se trata de un sistema de varios componentes virales, donde se ha descrito características bioquímicas diferentes para las dos proteínas de movimiento. De esta forma, la proteína soluble p7A es la encargada de llevar el RNA del virus a los PD a los que llega mediante el aparato de Golgi, posiblemente interaccionando con factores del mismo. La proteína transmembrana p7B llega a los PD siguiendo la ruta biosintéticasecretora a través del aparato de Golgi. La función de la misma en el movimiento de MNSV podría darse a nivel de los PD. 


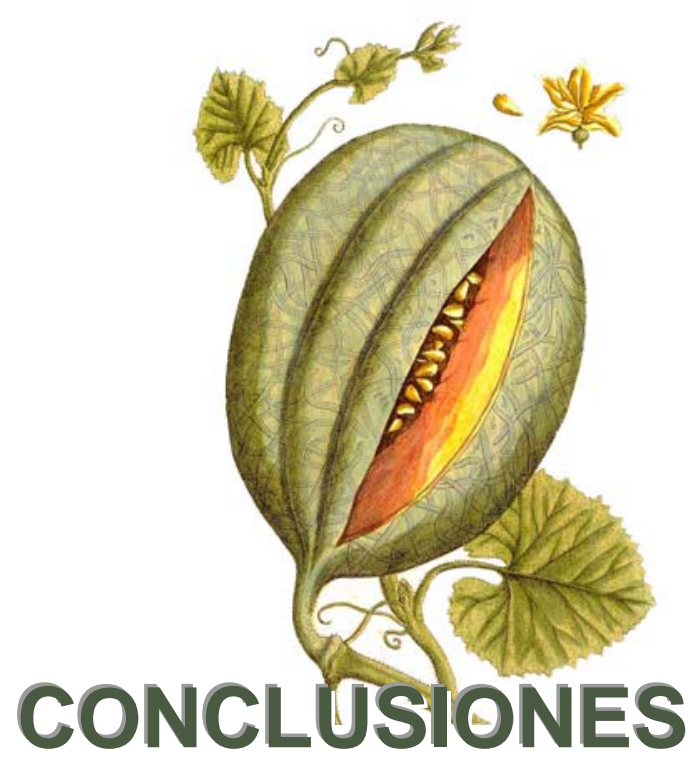


1. Se ha generado un clon de cDNA del MNSV, pMNSV(Al), a partir del cual se pueden sintetizar in vitro transcritos que son infecciosos tras su inoculación mecánica en el huésped natural Cucumis melo. Este clon ha constituido una herramienta sumamente útil en el estudio funcional del genoma del MNSV. Asimismo, se ha obtenido un clon quimera del MNSV, pMNSV(Al)- $\Delta c p-G F P$, en el que se ha sustituido el gen de la proteína de cubierta viral (CP) por el gen delator de la proteína de fluorescencia verde (GFP). Este clon nos ha permitido visualizar el movimiento del virus mediante técnicas de microscopía confocal.

2. Se ha demostrado la función de cada una de las proteínas codificadas en el genoma del MNSV en los diferentes pasos del ciclo de infección del virus, incluyendo la replicación y el movimiento, así como en el silenciamiento de RNA de la planta. De esta forma, se ha observado que p29 y p89 están implicadas en los procesos de replicación viral, probablemente formando parte del complejo replicativo. Además, se ha demostrado que p7A y p7B son las proteínas de movimiento (MP) del MNSV y ambas son necesarias para que se dé el movimiento intra- e intercelular del virus. Por último, se ha puesto de manifiesto que p42, la proteína de cubierta (CP) del virus, actúa como determinante de patogenicidad viral, probablemente promoviendo el movimiento local, y es esencial para la infección sistémica. Asimismo, tanto la p42 como la p7B actúan como supresores débiles del silenciamiento de RNA en experimentos de expresión transitoria.

3. Los ensayos de retardo en la movilidad electroforética realizados con la proteína de movimiento p7A indican que ésta es capaz de unir RNA de forma cooperativa y sin especificidad de secuencia aparente. Mediante mutagénesis dirigida de residuos de la secuencia peptídica de la p7A se ha demostrado que los aminoácidos básicos, la estructura secundaria en $\alpha$-hélice de la región central y el motivo conservado FNF del extremo Ct están implicados en la unión a RNA de la proteína. Por último, se ha determinado que la capacidad de unión a RNA mostrada por la p7A es esencial para el movimiento célula a célula del MNSV.

4. La proteína de movimiento p7B es una proteína integral de membrana que presenta una doble topología in vivo. Mediante mutagénesis dirigida de residuos de la secuencia peptídica de la p7B se ha puesto de manifiesto que aquellos factores de su secuencia que modifican la capacidad de inserción a la membrana de la proteína p7B afectan negativamente al movimiento célula a célula del MNSV. Además, la dimerización de la misma desempeña un papel clave en su implicación en el movimiento intracelular del virus. 
5. Se ha establecido el patrón de distribución subcelular de las proteínas de movimiento del MNSV. La proteína hidrofílica p7A se asocia a las vesículas del aparato de Golgi interaccionando, posiblemente, con factores del huésped. La proteína hidrofóbica p7B entra en la ruta biosintética/secretora de la célula a través del RE y alcanza posteriormente las vesículas del aparato de Golgi. Tanto la p7A como la p7B se localizan en los plasmodesmos celulares. El tratamiento con Brefeldina $A$, droga que inhibe la ruta secretora de la planta actuando directamente sobre el transporte entre el RE y el aparato de Golgi, bloquea la localización de ambas proteínas en los PD indicando que tanto la p7A como la p7B alcanzan los mismos vía el aparato de Golgi.

6. El movimiento del virus MNSV se ve afectado negativamente por la presencia en el tejido infectado de Brefeldina A. Este dato implica al aparato de Golgi en el movimiento del MNSV. Ni la asociación de las proteínas de movimiento virales con las vesículas del aparato de Golgi, ni el efecto inhibitorio de Brefeldina A sobre el movimiento de un virus de plantas ha sido descrito con anterioridad. Por todo ello, la presente tesis concluye con un nuevo modelo de movimiento intracelular para virus patógenos de plantas en el que las proteínas de movimiento del virus utilizan el la ruta secretora de la célula a través de las vesículas del aparato de Golgi para alcanzar los PD celulares. 


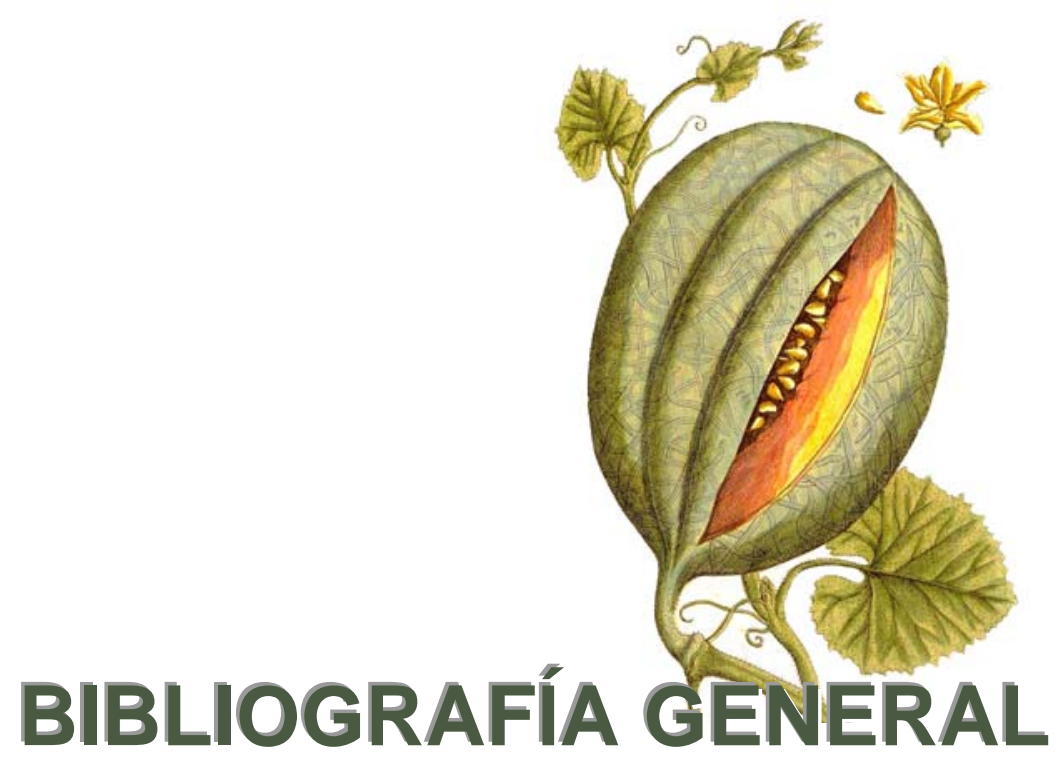




\section{BIBLIOGRAFÍA}

Akgoz, M., Nguyen, Q. N., Talmadge, A. E., Drainville, K. E. y Wobbe, K.K. (2001) Mutational analysis of Turnip crinkle virus movement protein p8. Mol. Plant Pathol., 2:37-48.

Alberts, B., Bray, D., Lewis, J., Raff, M., Roberts, K. y Watson, J.D. (1996) Biología molecular de la célula. pp 641-697. Ediciones Omega, S.A., Barcelona.

Allan, V.J., Thompson, H.M. y McNiven, M.A. (2002) Motoring around the Golgi. Nat Cell Biol., 4:236-242.

Anandalakshmi, R., Marathe, R., Ge, X., Herr, J.M. Jr., Mau, C., Mallory, A., Pruss, G., Bowman, L. y Vance, V.B. (2000) A calmodulin-related protein that suppresses posttranscriptional gene silencing in plants. Science, 290:142-144.

Andreeva, A.V., Zheng, H., Saint-Jore, C.M., Kutuzov, M.A., Evans, D.E. y Hawes, C.R. (2000) Organization of transport from endoplasmic reticulum to Golgi in higher plants. Biochem Soc Trans., 28:505-512.

Aniento, F. y Robinson, D.G. (2005) Testing for endocytosis in plants. Protoplasma, 226:3-11.

Aparicio. F., Myrta, A., Di Terlizzi, B. y Pallas, V. (1999) Molecular variability among isolates of Prunus necrotic ringspot virus from different Prunus spp. Phytopathology, 89:991-999.

Aparicio F., Sanchez-Navarro J.A., y Pallas, V. (2006) In vitro and in vivo mapping of the Prunus necrotic ringspot virus coat protein $\mathrm{C}$-terminal dimerization domain by bimolecular fluorescence complementation. J. Gen. Virol., 87:1745-1750.

Aparicio, F., Vilar, M., Perez-Paya, E. y Pallas, V. (2003) The coat protein of prunus necrotic ringspot virus specifically binds to and regulates the conformation of its genomic RNA. Virology, 313:213-223.

Ashby, J., Boutant, E., Seemanpillai, M., Groner, A., Sambade, A., Ritzenthaler, C. y Heinlein, M. (2006) Tobacco mosaic virus movement protein functions as a structural microtubuleassociated protein. J Virol., 80:8329-8344.

Astruc, N., Marcos, J.F., Macquaire, G., Candresse, T. y Pallás, V. (1996) Studies on the diagnosis of hop stunt viroid in fruit trees: Identification of new hosts and application of a nucleic acid extraction procedure based on non-organic solvents. Eur J. Plant Pathol., 102:837-846.

Asurmendi, S., Berg, R.H., Koo, J.C. y Beachy, R.N. (2004) Coat protein regulates formation of replication complexes during tobacco mosaic virus infection. Proc Natl Acad Sci USA., 101:1415-1420.

Atkins, D., Hull, R., Wells, B., Roberts, K., Moore, P. y Beachy, R.N. (1991) The Tobacco Mosaic Virus-30K Movement Protein in Transgenic Tobacco Plants Is Localized to Plasmodesmata. J Gen Virol., 72:209-211.

Baker, A. y Sparkes, I.A. (2005) Peroxisome protein import: some answers, more questions. Curr Opin Plant Biol., 8:640-647. 
Barlowe, C. (2003) Signals for COPII-dependent export from the ER: what's the ticket out?. Trends Cell. Biol., 13:295-300.

Barr, F.A. y Short, B. (2003) Golgins in the structure and dynamics of the Golgi apparatus. Curr Opin Cell Biol., 15:405-413.

Baulcombe, D.C. (2000) Molecular biology. Unwinding RNA silencing. Science, 290:1108-1109.

Baulcombe, D.C., Chapman, S. y Santa Cruz, S. (1995) Jellyfish green fluorescent protein as a reporter for virus infections. Plant J., 7:1045-1053.

Bayne, E.H., Rakitina, D.V., Morozov, S.Y. y Baulcombe, D.C. (2005) Cell-to-cell movement of Potato Potexvirus $X$ is dependent on suppression of RNA silencing. Plant J., 44:471-482.

Bent, A.F. (1996) Plant Disease Resistance Genes: Function Meets Structure. Plant Cell, 8:1757-1771.

Bernstein, E., Candy, A., Hammond, S. y Hannon, G. (2001) Role for a bidentate ribonuclease in the initation step of RNA interference. Nature, 409:363-366.

Bloom, K. y Beach, D.L. (1999) mRNA localization: motile RNA, asymmetric anchors. Curr Opin Micro., 2:604-609.

Boevink, P., Oparka, K., Santa Cruz, S., Martin, B., Betteridge, A. y Hawes, C. (1998) Stacks on tracks: the plant Golgi apparatus traffics on an actin/ER network. Plant J., 15:441-447.

Boevink, P. y Oparka, K. J. (2005) Virus-host interactions during movement processes. Plant Physiol., 138:1815-1821.

Bol, J.F. (2005) Replication of alfamo- and ilarviruses: Role of the coat protein. Ann Review Phytopathol., 43:39-62.

Bordier, C. (1981) Phase separation of integral membrane proteins in Triton X-114 solution. $J$ Biol Chem., 256:1604-1607.

Bos, L., Vandorst, H.J.M., Huttinga, H. y Maat, D.Z. (1984) Further Characterization of Melon Necrotic Spot Virus Causing Severe Disease in Glasshouse Cucumbers in the Netherlands and Its Control. Netherlands. J Plant Pathol., 90:55-69.

Boyer, J.C. y Haenni, A.L. (1994) Infectious transcripts and CDNA clones of RNA viruses.Virology, 198:415-26.

Boyko, V., Ashby, J.A., Suslova, E., Ferralli, J., Sterthaus, O., Deom, C.M. y Heinlein, M. (2002) Intramolecular complementing mutations in Tobacco mosaic virus movement protein confirm a role for microtubule association in viral RNA transport. J Virol., 76:3974-3980.

Boyko, V., Ferralli, J., Ashby, J., Schellenbaum, P. y Heinlein, M. (2000a) Function of microtubules in intercellular transport of plant virus RNA. Nature Cell Biology, 2:826-832.

Boyko, V., Ferralli, J. y Heinlein, M. (2000b) Cell-to-cell movement of TMV RNA is temperaturedependent and corresponds to the association of movement protein with microtubules. Plant J., 22:315-325.

Boyko, V., Hu, Q., Seemanpillai, M., Ashby, J. y Heinlein, M. (2007) Validation of microtubuleassociated Tobacco mosaic virus RNA movement and involvement of microtubule-aligned particle trafficking. Plant J., 51:589-603. 
Boyko, V., van der Laak, J., Ferralli, J., Suslova, E., Kwon, M.O. y Heinlein, M. (2000c) Cellular targets of functional and dysfunctional mutants of tobacco mosaic virus movement protein fused to green fluorescent protein. J Virol., 74:11339-11346.

Bozarth, C.S., Weiland, J.J. y Dreher, T.W. (1992) Expression of ORF-69 of Turnip yellow mosaic virus is necessary for viral spread in plants. Virology, 187:124-130.

Brandizzi, F., Snapp, E.L., Roberts, A.G., Lippincott-Schwartz, J. y Hawes, C. (2002) Membrane protein transport between the endoplasmic reticulum and the golgi in tobacco leaves is energy dependent but cytoskeleton independent: Evidence from selective photobleaching. Plant Cell, 14:1293-1309.

Brigneti, G., Voinnet, O., Li, W.X., Ji, L.H., Ding, S.W. y Baulcombe, D.C. (1998) Viral pathogenicity determinants are suppressors of transgene silencing in Nicotiana benthamiana. EMBO J., 17:6739-6746.

Brill, L.M., Nunn, R.S., Kahn, T.W., Yeager, M. y Beachy, R.N. (2000) Recombinant tobacco mosaic virus movement protein is an RNA-binding, alpha-helical membrane protein. Proc Natl Acad Sci U S A., 97:7112-7117.

Brodersen, P. y Voinnet, O. (2006) The diversity of RNA silencing pathways in plants. Trends Genet., 22:268-280.

Burd, C.G. y Dreyfuss, G. (1994) Conserved structures and diversity of functions of RNAbinding proteins. Science, 256:615-621.

Campbell, R.N. y Sim, S.T. (1994) Host specificity and nomenclature of Olpidium bornovanus (=Olpidium radicale) and comparisons to Olpidium brassicae. Can J Bot., 72:1136-1143.

Campbell, R.N., WipfScheibel, C. y Lecoq, H. (1996) Vector-assisted seed transmission of melon necrotic spot virus in melon. Phytopathology, 86:1294-1298.

Canto, T. y Palukaitis, P. (2005) Subcellular distribution of mutant movement proteins of Cucumber mosaic virus fused to green fluorescent proteins. J Gen Virol., 86:1223-1228.

Cañizares, M.C., Marcos, J.F. y Pallas, V. (2001) Molecular variability of twenty-one geographically distinct isolates of Carnation mottle virus (CarMV) and phylogenetic relationships within the Tombusviridae family. Arch Virol., 146:2039-2051.

Carey, J. (1991) Gel retardation. In Methods in Enzymology. Protein-DNA Interactions. pp. 103117. Edited by R.T. Sauer. Academic Press. San Diego, CA.

Carpenter, C.D. y Simon, A.E. (1998) Analysis of sequences and predicted structures required for viral satellite RNA accumulation by in vivo genetic selection. Nucleic Acids Research, 26:2426-2432.

Carrington, J.C. (2000) RNA silencing. Moving targets. Nature, 408:150-151.

Carrington, J.C., Heaton, L.A., Zuidema, D., Hillman, B.I. y Morris, T.J. (1989) The genome structure of Turnip crinkle virus. Virology, 170:219-226.

Carrington, J.C., Kasschau, K.D., Majan, S.K. y Schaad, M.C. (1996) Cell-to-Cell and LongDistance Transport of Viruses in Plants. Plant Cell, 8:1669-1681. 
Carrington, J.C. y Morris, T.J. (1986) High-Resolution Mapping of Carnation Mottle VirusAssociated Rnas. Virology, 150:196-206.

Carrington, J.C., Morris, T.J., Stockley, P.G. y Harrison, S.C. (1987) Structure and Assembly of Turnip Crinkle Virus .4. Analysis of the Coat Protein Gene and Implications of the Subunit Primary Structure. J Mol Biol., 194:265-276.

Castano, A. y Hernandez, C. (2005) Complete nucleotide sequence and genome organization of Pelargonium line pattern virus and its relationship with the family Tombusviridae. Arch Virol., 150:949-65.

Chen. M. H., Sheng, J., Hind, G., Handa, A. K. y Citovsky, V. (2000) Interaction between the tobacco mosaic virus movement protein and host cell pectin methylesterases is required for viral cell-to-cell movement. EMBO J., 19:913-920.

Chen, M-H., Tian, G.W., Gafni, Y. y Citovsky, V. (2005) Effects of calreticulin on viral cell-to-cell movement. Plant Physiol., 138:1866-1876.

Choi, S.K., Hema, M., Gopinath, K., Santos, J. y Kao, C. (2004) Replicase-binding sites on plusand minus-strand brome mosaic virus RNAs and their roles in RNA replication in plant cells. J Virol., 78:13420-13429.

Citovsky, V., Knorr, D., Schuster, G. y Zambryski, P. (1990) The p30 movement protein of Tobacco mosaic virus is a single-strand nucleic acid binding protein. Cell, 60:637-647.

Citovsky, V., Lee, I.-Y., Vyas, S., Glick, E., Chen, M.-H., Vainstein, A., Gafni, Y., Gelvin, S. B. y Tzfira, T. (2006) Subcellular localization of interacting proteins by bimolecular fluorescence complementation in planta. J. Mol. Biol., 362:1120-1131.

Citovsky, V., Wong, M.L., Shaw, A.L., Prasad, B.V.V. y Zambryski, P. (1992) Visualization and Characterization of Tobacco Mosaic-Virus Movement Protein-Binding to Single-Stranded Nucleic-Acids. Plant Cell, 4:397-411.

Claros, M.G. y von Heijne, G. (1994) TopPred II: An improved software for membrane protein structure prediction. CABIOS, 10:685-686.

Cohen, Y., Gisel, A. y Zambryski, P.C. (2000a) Cell-to-cell and systemic movement of recombinant green fluorescent protein-tagged Turnip crinkle virus. Virology, 273:258-266.

Cohen, Y., Qu, F., Gisel, A., Morris, T.J. y Zambryski, P.C. (2000b) Nuclear localization of turnip crinkle virus movement protein p8. Virology, 273:276-285.

Compton, S. L. y Behrend, E. N. (2006) PRAF1: a Golgi complex transmembrane protein that interacts with viruses Biochem. Cell Biol., 84:940-948.

Conejero, V. y Semancik, J.S. (1977) Exocortis viroid: alteration in the proteins of Gynura aurantiaca accompanying viroid infection. Virology, 77:221-232.

Contreras, I., Ortiz-Zapater, E. y Aniento, F. (2004a) Sorting signals in the cytosolic tail of membrane proteins involved in the interaction with plant ARF1 and coatomer. Plant J., 38:685-698. 
Contreras, I., Yang, Y., Robinson, D.G. y Aniento, F. (2004b) Sorting signals in the cytosolic tail of plant p24 proteins involved in the interaction with the COPII coat. Plant Cell Physiol., 45:1779-1786

Covelli, L., Coutts, R.H., Di Serio, F., Citir, A., Acikgoz, S., Hernandez, C., Ragozzino, A. y Flores, R. (2004) Cherry chlorotic rusty spot and Amasya cherry diseases are associated with a complex pattern of mycoviral-like double-stranded RNAs. I. Characterization of a new species in the genus Chrysovirus. J Gen Virol., 85:3389-3397.

Cowan, G.H., Lioliopoulou, F., Ziegler, A. y Torrance, L. (2002) Subcellular localisation, protein interactions, and RNA binding of potato mop-top virus triple gene block proteins. Virology, 298:106-115.

Crawford, K.M. y Zambryski, P.C. (2001) Non-targeted and targeted protein movement through plasmodesmata in leaves in different developmental and physiological states. Plant Physiol., 125:1802-1812.

Curin, M., Ojangu E-L., Trutnyeva, K., Ilau, B., Truve, E. y Waigmann, E. (2007) MPB2C, a Microtubule-Associated Plant Factor, Is Required for Microtubular Accumulation of Tobacco Mosaic Virus Movement Protein in Plants. Plant Physiol., 143:801-811.

Danon, A. y Mayfield, S.P. (1991) Light regulated translational activators: identification of chloroplast gene specific mRNA binding proteins. EMBO J., 10:3993-4001.

Daròs, J.A. y Carrington, J.C. (1997) RNA binding activity of Nla proteinase of Tobacco etch potyvirus. Virology, 237:327-336.

daSilva, L.L., Snapp, E.L., Denecke, J., Lippincott-Schwartz, J. Hawes, C. y Brandizzi, F. (2004) Endoplasmic reticulum export sites and Golgi bodies behave as single mobile secretory units in plant cells. Plant Cell, 16:1753-1771.

Deber, C.M. y Therien, A.G. (2002) Putting the $\beta$-breaks on membrane protein misfolding. Nature Struct. Biol., 9:318-319.

Denecke, J., Botterman, J. y Deblaere, R. (1990) Protein secretion in plant cells can occur via a default pathway. Plant Cell, 2:51-59.

Denecke, J., De Rycke, R. y Botterman, J. (1992) Plant and mammalian sorting signals for protein retention in the endoplasmic reticulum contain a conserved epitope. EMBO J., 11:2345-2355.

Deom, C.M., Schubert, K.R., Wolf, S., Holt, C.A., Lucas, W.J. y Beachy, R.N. (1990) Molecular Characterization and Biological Function of the Movement Protein of Tobacco MosaicVirus in Transgenic Plants. Proc Natl Acad Sci USA., 87:3284-3288.

Diaz, J.A., Bernal, J.J., Moriones, E. y Aranda, M.A. (2003) Nucleotide sequence and infectious transcripts from a full-length cDNA clone of the carmovirus Melon necrotic spot virus. Arch Virol., 148:599-607.

Diaz, A., Horjales, E., Rudino-Pinera, E., Arreola, R. y Hansberg, W. (2004) Unusual Cys-Tyr 
covalent bond in a large catalase. J Mol Biol., 342:971-985.

Diaz, J.A., Nieto, C., Moriones, E., Truniger, V. y Aranda, M.A. (2004) Molecular characterization of a Melon necrotic spot virus strain that overcomes the resistance in melon and nonhost plants. Mol Plant-Microbe Int., 17:668-675.

Ding, B., Haudenshield, JS., Hull, R.J., Wolf, S., Beachy, R.N. y Lucas, W.J. (1992) Secondary Plasmodesmata Are Specific Sites of Localization of the Tobacco Mosaic-Virus Movement Protein in Transgenic Tobacco Plants. Plant Cell, 4:915-928.

Ding, B., Li, Q., Nguyen, L., Palukaitis, P. y Lucas, W.J. (1995) Cucumber mosaic virus 3a protein potentiates cell-to-cell trafficking of CMV RNA in tobacco plants. Virology, 207:345-353.

Ding, X.S., Liu, J.Z., Cheng, N.H., Folimonov, A., Hou, Y.M., Bao, Y.M., Katagi, C., Carter, S.A. y Nelson, R.S. (2004) The Tobacco mosaic virus 126-kDa protein associated with virus replication and movement suppresses RNA silencing. Mol Plant-Microbe In., 17:583-592.

Dohi, K., Mise, K., Furusawa, I. y Okuno, T. (2002) RNA-dependent RNA polymerase complex of Brome mosaic virus: analysis of the molecular structure with monoclonal antibodies. $J$ Gen Virol., 83:2879-2890.

Drakakaki, G., Zabotina, O., Delgado, I., Robert, S., Keegstra, K. y Raikhel, N. (2006) Arabidopsis reversibly glycosylated polypeptides 1 and 2 are essential for pollen development. Plant Physiol., 142:1480-1492.

Drapper D. E. (1999) Themes in RNA-protein recognition. J. Mol. Biol., 293:255-270.

Dunlop, J., Jones, P.C., y Finbow, M.E. (1995) Membrane insertion and assembly of ductin a polytopic channel with dual orientations. EMBO J., 14:3609-3616.

Dunoyer, P. y Voinnet, O. (2005) The complex interplay between plant viruses and host RNAsilencing pathways. Curr Opin Plant Biol., 8:415-423.

Ehlers, K. y Kollmann, R. (2001) Primary and secondary plasmodesmata: Structure, origin, and functioning. Protoplasma, 216:1-30.

Ellis, J., Dodds, P. y Prior, T. (2000) The generation of plant disease resistance gene specificities. Trends Plant Sci., 5:373-379.

Erhardt, M., Morant, M., Ritzenthaler, C., Stussi-Garaud, C., Guilley, H., Richards, k., Jonard, G., Bouzoubaa, S. y Gilmer, D. (2000) P42 movement protein of Beet necrotic yellow vein virus is targeted by the movement proteins $\mathrm{P} 13$ and $\mathrm{P} 15$ to punctuate bodies associated with plasmodesmata. Mol. Plant-Microbe In., 13:520-528.

Erhardt, M., Stussi-Garaud, C., Guilley, H., Richards, K.E., Jonard, G. y Bouzoubaa, S. (1999) The first triple gene block protein of peanut clump virus localizes to the plasmodesmata during virus infection. Virology, 264:220-229.

Fauquet, C. M., Mayo, M.A., Maniloff, J. y Desselberger, U. (2005) Virus Taxonomy: VIIIth Report of the International Committee on Taxonomy of Viruses. 
Ferralli, J., Ashby, J., Fasler, M., Boyko, V. y Heinlein, M. (2006) Disruption of microtubule organization and centrosome function by expression of Tobacco mosaic virus movement protein. J Virol., 80:5807-5821.

Fisher, D.B. y Oparka, K.J. (1996) Post-phloem transport: Principles and problems. J. Exp. Bot., 47:1141-1154.

Flor, H. (1971) Current status of the gene-for-gene concept. Annu. Rev. Phytophatol., 9:275296.

Florentino, L.H., Santos, A.A., Fontenelle, M.R., Pinheiro, G.L., Zerbini, F.M., Baracat-Pereira, M.C. y Fontes, E.P. (2006) A PERK-like receptor kinase interacts with the geminivirus nuclear shuttle protein and potentiates viral infection. J Virol., 80:6648-6656.

Frand, A.R., Cuozzo, J.W. y Kaiser, C.A. (2000) Pathways for protein disulphide bond formation. Trends Cell Biol., 10:203-210.

Furuki, I. (1981) Epidemiological studies on melon necrotic spot. Technical Bulletin 14. Shizuoka Agricultural Experiment Station, Shizuokaken, Japan.

Fujiki, M., Kawakami, S., Kim, RW. y Beachy, R.N. (2006) Domains of tobacco mosaic virus movement protein essential for its membrane association. J Gen Virol., 87:2699-2707.

Fujita, M., Mise, K., Kajiura, Y., Dohi, K. y Furusawa, I. (1998) Nucleic acid-binding properties and subcellular localization of the $3 a$ protein of brome mosaic bromovirus. J Gen Virol., 79:1273-1280.

Garcia-Castillo, S., Sanchez-Pina, M.A. y Pallas, V. (2003) Spatio-temporal analysis of the RNAs, coat and movement (p7) proteins of Carnation mottle virus in Chenopodium quinoa plant. J Gen Virol., 84:745-749.

Garcia-Saez, A.J., Mingarro, I., Perez-Paya, E. y Salgado, J. (2004) Membrane-insertion fragments of Bcl-xL, Bax, and Bid. Biochemistry, 43:10930-10943.

Genoves, A., Navarro, J.A. y Pallas, V. (2006) Functional analysis of the five Melon necrotic spot virus genome-encoded proteins. J Gen Virol., 87:2371-2380.

Giesman-Cookmeyer, D., Silver, S., Vaewhongs, A.A., Lommel, S.A. y Deom, C.M. (1995) Tobamovirus and dianthovirus movement proteins are functionally homologous. Virology, 213:38-45

Gilbertson, R.L. y Lucas, W.J. (1996) How do viruses traffic on the vascular highway? Trends in Plant Sci., 1:260-268.

Gillespie, T., Boevink, P., Haupt, S., Roberts, A.G., Toth, R., Valentine, T., Chapman, S. y Oparka, K.J. (2002) Functional analysis of a DNA-shuffled movement protein reveals that microtubules are dispensable for the cell-to-cell movement of Tobacco mosaic virus. Plant Cell, 14:1207-1222.

Giraudo, G. y Maccioni, J.F. (2003) Endoplasmic Reticulum Export of Glycosyltransferases Depends on Interaction of a Cytoplasmic Dibasic Motif with Sar1. Mol Biol Cell. 14: 37533766. 
Gomez, G. y Pallas, V. (2001) Identification of an in vitro ribonucleoprotein complex between a viroid RNA and a phloem protein from cucumber plants. Mol Plant-Microbe In., 14:910913.

Gomez, G. y Pallas, V. (2004) A long-distance translocatable phloem protein from cucumber forms a ribonucleoprotein complex in vivo with Hop stunt viroid RNA. J Virol., 78:1010410110.

Gomez, G., Torres, H. y Pallas, V. (2005) Identification of translocatable RNA-binding phloem proteins from melon, potential components of the long-distance RNA transport system. Plant J., 41:107-116.

Gorshkova, E.N., Erokhina, T.N., Stroganova, T.A., Yelina, N.E., Zamyatnin, A.A., Kalinina, N.O., Schiemann, J., Solovyev, A.G. y Morozov, S.Y. (2003) Immunodetection and fluorescent microscopy of transgenically expressed hordeivirus TGBp3 movement protein reveals its association with endoplasmic reticulum elements in close proximity to plasmodesmata. J Gen Virol., 84:985-994.

Gosalvez-Bernal, B., Garcia-Castillo, S., Pallas, V. y Sanchez-Pina, M.A. (2006) Distribution of carnation viruses in the shoot tip: Exclusion from the shoot apical meristem. Physiol Mol Plant P., 69:43-51.

Gosalvez-Bernal, B. Genoves, A. Navarro, J.A. Pallas, V y Sanchez-Pina, M.A.Distribution and pathway for phloem-dependent movement of Melon necrotic spot virus in melon plants. Enviado.

Gosalvez, B., Navarro, J.A., Lorca, A., Botella, F., Sanchez-Pina, M.A. y Pallas, V. (2003) Detection of Melon necrotic spot virus in water samples and melon plants by molecular methods. J Virol Meth., 113:87-93.

Guan, H.C., Carpenter, C.D. y Simon, A.E. (2000a) Analysis of cis-acting sequences involved in plus-strand synthesis of a turnip crinkle virus-associated satellite RNA identifies a new carmovirus replication element. Virology, 268:345-354.

Guan, H.C., Carpenter, C.D. y Simon, A.E. (2000b) Requirement of a 5 '-proximal linear sequence on minus strands for plus-strand synthesis of a satellite RNA associated with turnip crinkle virus. Virology, 268:355-363.

Guan, H.C., Song, C.Z. y Simon, A.E. (1997) RNA promoters located on (-)-strands of a subviral RNA associated with turnip crinkle virus. Rna-A Publication of the Rna Society, 3:14011412.

Gutensohn, M., Fan, E., Frielingsdorf, S., Hanner, P., Hou, B., Hust, B. y Klosgen, R.B. (2006) Toc, Tic, Tat et al.: structure and function of protein transport machineries in chloroplasts. J Plant Physiol., 163:333-347. 
Hacker, D.L., Petty, I.T.D., Wei, N. y Morris, T.J. (1992) Turnip Crinkle Virus Genes Required for Rna Replication and Virus Movement. Virology, 186:1-8.

Hall, K.B. (2002) RNA-protein interactions. Curr Opin Struct Biol., 12:283-288.

Hamilton, A.J. y Baulcombe, D.C. (1999) A species of small antisense RNA in posttranscriptional gene silencing in plants. Science, 286:950-952.

Hammond-Kosack, K.E. y Jones, J.D. (1997) Plant Disease Resistance Genes. Annu Rev Plant Physiol Plant Mol Biol., 48:575-607

Hanton, S.L., Bortolotti, L.E., Renna, L., Stefano, G. y Brandizzi, F. (2005) Crossing the divide Transport between the endoplasmic reticulum and Golgi apparatus in plants. Traffic, 6:267-277.

Hanton, S.L., Matheson, L.A. y Brandizzi, F. (2006) Seeking a way out: export of proteins from the plant endoplasmic reticulum. Trends in Plant Science, 11:335-343.

Hanton, S.L., Matheson, L.A., Chatre, L., Rossi, M. y Brandizzi, F. (2007) Post-Golgi protein traffic in the plant secretory pathway. Plant Cell Rep., 26:1431-1438.

Hanton, S. L., Renna, L., Bortolotti, L. E., Chatre, L., Stefano, G. y Brandizzi, F. (2005) Diacidic Motifs Influence the Export of Transmembrane Proteins from the Endoplasmic Reticulum in Plant Cells. Plant Cell, 17:3081-3093.

Happel, N., Honing, S., Neuhaus, J.M., Paris, N., Robinson, D.G. y Holstein, S.E. (2004) Arabidopsis mu A-adaptin interacts with the tyrosine motif of the vacuolar sorting receptor VSR-PS1. Plant J., 37:678-693.

Harbison, S.A., Davies, J.W. y Wilson, T.M.A. (1985) Expression of High-Molecular-Weight Polypeptides by Carnation Mottle Virus-Rna. J GenVirol., 66:2597-2604.

Harbison, S.A., Wilson, T.M.A. y Davies, J.W. (1984) An Encapsilated, Subgenomic MessengerRna Encodes the Coat Protein of Carnation Mottle Virus. Bioscience Rep., 4:949-956.

Hardwick, K.G. y Pelham, H.R. (1992) SED5 encodes a 39-kD integral membrane protein required for vesicular transport between the ER and the Golgi complex. J Cell Biol., 119:513-521.

Haupt, S., Cowan, G.H., Ziegler, A., Roberts, A.G., Oparka, K.J. y Torrance, L. (2005) Two plant-viral movement proteins traffic in the endocytic recycling pathway. Plant Cell, 17:164-181.

Hayes, R.J., Pereira, V.C.A., Mcquillin, A. y Buck, K.W. (1994) Localization of Functional Regions of the Cucumber Mosaic-Virus Rna Replicase Using Monoclonal and Polyclonal Antibodies. J Gen Virol., 75:3177-3184.

Hawes, C. y Satiat-Jeunemaitre, B. (2005) The plant Golgi apparatus--going with the flow. Biochim Biophys Acta., 1744:466-480.

Hearne, P.Q., Knorr, D.A,, Hillman, B.I. y Morris, T.J. (1990) The complete genome structure and synthesis of infectious RNA from clones of Tomato bushy stunt virus. Virology, 177:141-151.

Heath, M.C. (2000) Hypersensitive response-related death. Plant Mol Biol. 44:321-334. 
Heaton, L.A., Lee, T.C., Wei, N. y Morris, T.J. (1991) Point Mutations in the Turnip Crinkle Virus Capsid Protein Affect the Symptoms Expressed by Nicotiana-Benthamiana. Virology, 183:143-150.

Heinlein, M. y Epel, B.L. (2004) Macromolecular transport and signaling through plasmodesmata. Int Rev Cytol., 235:93-164.

Heinlein, M., Epel, B.L., Padgett, H.S. y Beachy, R.N. (1995a) Interaction of Tobamovirus Movement Proteins with the Plant Cytoskeleton. Science, 270:1983-1985.

Heinlein, M., Epel, B.L., Padgett, H.S. y Beachy, R.N. (1995b) Tobamovirus Movement Proteins Interact with the Cytoskeleton in Infected-Cells. Mol Biol Cell., 6:554.

Heinlein, M., Padgett, H.S., Gens, J.S., Pickard, B.G., Casper, S.J., Epel, B.L. y Beachy, R.N. (1998a) Changing patterns of localization of the tobacco mosaic virus movement protein and replicase to the endoplasmic reticulum and microtubules during infection. Plant Cell, 10:1107-1120.

Heinlein, M., Wood, M.R., Thiel, T. y Beachy, R.N. (1998b) Targeting and modification of prokaryotic cell-cell junctions by tobacco mosaic virus cell-to-cell movement protein. Plant J., 14:345-351.

Herranz, M.C. y Pallas, V. (2004) RNA-binding properties and mapping of the RNA-binding domain from the movement protein of Prunus necrotic ringspot virus. J Gen Virol., 85:761-768.

Herranz, M.C., Sanchez-Navarro, J.A., Sauri, A., Mingarro, I. y Pallas, V. (2005) Mutational analysis of the RNA-binding domain of the Prunus necrotic ringspot virus (PNRSV) movement protein reveals its requirement for cell-to-cell movement. Virology, 339:31-41.

Hibi, T. y Furuki, I. (1985) Melon Necrotic Spot Virus. In: CMI: AAB Descriptions of Plants Viruses № 302.

Holweg, C. L. (2007) Living markers for actin block myosin-dependent motility of plant organelles and auxin. Cell Motil Cytoskeleton., 64:69-81.

Hong, W. (2005) SNAREs and traffic. Biochim Biophys Acta. 1744:493-517.

Howard, A.R., Heppler, M.L., Ju, H.J., Krishnamurthy, K., Payton, M.E. y Verchot-Lubicz, J. (2004) Potato virus X TGBp1 induces plasmodesmata gating and moves between cells in several host species whereas $\mathrm{CP}$ moves only in $\mathrm{N}$. benthamiana leaves. Virology, 328:185-197.

Huang, Z., Han, Y. y Howell, S.H. (2000) Formation of surface tubules and fluorescent foci in Arabidopsis thaliana protoplasts expressing a fusion between the green fluorescent protein and the cauliflower mosaic virus movement protein. Virology, 271:58-64.

Huang, C.Y., Huang, Y.L., Meng, M., Hsu, Y.H. y Tsai, C.H. (2001) Sequences at the 3' untranslated region of bamboo mosaic potexvirus RNA interact with the viral RNAdependent RNA . J Virol., 75:2818-2824.

Huang, M., Koh, D.C., Weng, L.J., Chang, M.L., Yap, Y.K., Zhang, L. y Wong, S.M. (2000).Complete nucleotide sequence and genome organization of Hibiscus chlorotic 
ringspot virus, a new member of the genus Carmovirus: evidence for the presence and expression of two novel open reading frames. J Virol., 74:3149-3155.

Hugouvieux, V., Kwak, J.M. y Schroeder, J.I. (2001) An mRNA cap binding protein, ABH1, modulates early abscisic acid signal transduction in Arabidopsis. Cell, 106:477-487.

Hull, R. (2002) Virus movement through the plant and effects on plant metabolism. In Matthews' plant virology, 4th edn, pp 373-436. Edited by Academic Press, San Diego.

Huppert, E., Szilassy, D., Salanki, K., Diveki, Z. y Balazs, E. (2002) Heterologous movement protein strongly modifies the infection phenotype of cucumber mosaic virus. J Virol., 76:3554-3557.

Hutcheson, S.W. (1998) Current concepts of active defense in plants. Annu Rev Phytopathol., 36, 59-90.

Hutvagner, G. (2005) Small RNA asymmetry in RNAi: function in RISC assembly and gene regulation. FEBS Lett., 579:5850-5857.

Jacobsen, S.E., Running, M.P. y Meyerowitz, E.M. (1999) Disruption of an RNA helicase/RNAse III gene in Arabidopsis causes unregulated cell division in floral meristems. Development, 126:5231-5243.

Jensen, K.H., Herrin, D.L., Plumley, F.G., Schmidt, G.W. (1986) Biogenesis of photosystem II complexes: transcriptional, translational, and posttranslational regulation. J Cell Biol., 103:1315-1325.

Jiang, L. y Rogers, J.C. (1998) Integral membrane protein sorting to vacuoles in plant cells: evidence for two pathways. J Cell Biol., 143:1183-1199.

Jones, S., Daley, D. T. A., Luscombe, N. M., Berman, H. M. y Thornton, J. M. (2001) ProteinRNA interactions: a structural analysis. Nucleic Acids Res., 29:943-954.

Ju, H.J., Brown, J.E., Ye, C.-M. y Verchot-Lubicz, J. (2007) Mutations in the central domain of Potato virus $X$ TGBp2 eliminate granular vesicles and virus cell-to-cell trafficking. J. Virol., 81:1899-1911.

Juárez, M., Ortega, A., Armengol, J., Martínez, G., García, J. y Jordá, C. (1993) Un virus en expansión: el cribado del melón. Phytoma España, 45.

Jürgens, G. (2004) Membrane trafficking in plants. Annu Rev Cell Dev Bi., 20:481-504.

Kadare, G. y Haenni, A.L. (1997) Virus-encoded RNA helicases. J Virol., 71:2583-2590.

Kadokura, H, Katzen, F., y Beckwith, J. (2003) Protein disulfide bond formation in prokaryotes. Anu. Rev. Biochem., 72:111-135.

Kakani, K., Robbins, M. y Rochon, D. (2003) Evidence that binding of cucumber necrosis virus to vector zoospores involves recognition of oligosaccharides. J Virol., 77:3922-3928.

Kakani, K., Sgro, J.Y. y Rochon, D. (2001) Identification of specific cucumber necrosis virus coat protein amino acids affecting fungus transmission and zoospore attachment. J Virol., 75:5576-5583. 
Kalinina, N.O., Rakitina, D.V., Solovyev, A.G., Schiemann, J. y Morozov, S.Y. (2002) RNA helicase activity of the plant virus movement proteins encoded by the first gene of the triple gene block. Virology, 296:321-329.

Kalinina, N. O., Rakitina, D. A., Yelina, N. E., Zamyatnin, A. A., Stroganova, T. A., Klinov, D. V., Prokhorov, V. V., Ustinova, S. V., Chernov, B. K., Schiemann, J., Solovyev, A. G. y Morozov, S. Y. (2001) RNA-binding properties of the $63 \mathrm{kDa}$ protein by the triple gene block of Poa semilatent hordeivirus. J. Gen. Virol., 82:2569-2578.

Karasev, A.V., Kashina, A.S., Gelfand, V.I. y Dolja, V.V. (1992) Hsp70-Related 65 Kda Protein of Beet Yellows Closterovirus Is A Microtubule-Binding Protein. Febs Lett., 304:12-14.

Karpova, O.V., Rodionova, N.P., Ivanov, K.I., Kozlovsky, S.V., Dorokhov, Y.L. y Atabekov, J.G. (1999) Phosphorylation of tobacco mosaic virus movement protein abolishes its translation repressing ability. Virology, 261:20-24.

Kasschau, K.D. y Carrington, J.C. (1998) A counterdefensive strategy of plant viruses: suppression of posttranscriptional gene silencing. Cell, 95:461-470.

Kasteel, D.T.J., vanderWel, N.N., Jansen, K.A.J., Goldbach, R.W. y vanLent, J.W.M. (1997) Tubule-forming capacity of the movement proteins of alfalfa mosaic virus and brome mosaic virus. J. Gen. Virol., 78:2089-2093.

Kasteel, D., Wellink, J., Goldbach, R.W. y van Lent, J.W. (1997) Isolation and characterization of tubular structures of Cowpea mosaic virus. J Gen Virol., 78:3167-3170.

Kasteel, D., Wellink, J., Verver, J., van Lent, J., Goldbach, R. y van Kammen, A. (1993) The involvement of cowpea mosaic virus M RNA-encoded proteins in tubule formation. J Gen Virol., 74:1721-1724.

Kawakami, S., Watanabe, Y. y Beachy, R.N. (2004) Tobacco mosaic virus infection spreads cell to cell as intact replication complexes. Proc Natl Acad Sci USA., 101:6291-6296.

Kempers, R., Prior, D.A.M., van Bel, A.J.E. y Oparka, K.J. (1993) Plasmodesmata between sieve elements and companion cell of extrafascicullar phoem of Cucurbita maxima permit passage of 3 KDA fluorescent proves. Plant J., 4:567-575.

Kempers, R. y van Bel, A.J.E. (1997) Symplasmic connections between sieve element and companion cell in the ítem phoem of Vicia faba have a molecular exclusion limit of at least 10 kDa. Planta, 201:195-201.

Kim, S.H., Ryabov, E.V., Kalinina, N.O., Rakitina, D.V., Gillespie, T., MacFarlane, S., Haupt, S., Brown, J.W.S. y Taliansky, M. (2007) Cajal bodies and the nucleolus are required for a plant virus systemic infection. EMBO J., 26:2169-2179.

Knapp, E., Dawson, W.O. y Lewandowski, D.J. (2001) Conundrum of the lack of defective RNAs (dRNAs) associated with tobamovirus Infections: dRNAs that can move are not replicated by the wild-type virus; dRNAs that are replicated by the wild-type virus do not move. J Virol., 75:5518-5525. 
Knoester M., van Loon LC., van den Heuvel J., Hennig J., Bol JF. y Linthorst HJM. (1998) Ethylene-insensitive tobacco lacks nonhost resistance against soil-borne fungi. Proc Natl Acad Sci U S A., 95:1933-1937.

Koev, G. y Miller, W.A. (2000) A positive-strand RNA virus with three very different subgenomic RNA promoters. J Virol., 74:5988-5996.

Kong, Q.Z., Oh, J.W., Carpenter, C.D. y Simon, A.E. (1997) The coat protein of turnip crinkle virus is involved in subviral RNA-mediated symptom modulation and accumulation. Virology, 238:478-485.

Kotlizky, G., Boulton, M.I., Pitaksutheepong, C., Davies, J.W. y Epel, B.L. (2000) Intracellular and intercellular movement of maize streak geminivirus V1 and V2 proteins transiently expressed as green fluorescent protein fusions. Virology, 274:32-38.

Kotlizky, G., Katz, A., van der Laak, J., Boyko, V., Lapidot, M., Beachy, R.N., Heinlein, M. y Epel, B.L. (2001) A dysfunctional movement protein of Tobacco mosaic virus interferes with targeting of wild-type movement protein to microtubules. Mol Plant-Microbe In., 14:895904.

Krogh, A., Larsson, B., von Heijne, G. y Sonnhammer, E.L. (2001) Predicting transmembrane protein topology with a hidden Markov model: application to complete genomes. $\mathrm{J} \mathrm{Mol}$ Biol., 305:567-580.

Kubo, C., Nakazono-Nagaoka, E., Hagiwara, K., Kajihara, H., Takeuchi, S., Matsuo, K., Ichiki, T. U. y Omura, T. (2005) New severe strains of Melon necrotic spot virus: symptomatology and sequencing. Plant Pathol., 54:615-620.

Kunik, T., Palanichelvam, K., Czosnek, H., Citovsky, V. y Gafni, Y. (1998) Nuclear import of the capsid protein of tomato yellow leaf curl virus (TYLCV) in plant and insect cells. Plant J., 13:393-399.

Lamb, C. y Dixon, R.A. (1997) The oxidative burst in plant disease reistance. Annu Rev Plant Physiol Plant Mol Biol., 48:251-275.

Lange, L. y Insunza, V. (1977) Root inhabiting Olpidium species: the O. radicale complex. British Mycol Soc., 69:377-384.

Laporte, C., Vetter, G., Loudes, A.M., Robinson, D.G., Hillmer, S., Stussi-Garaud, C. y Ritzenthaler, C. (2003) Involvement of the secretory pathway and the cytoskeleton in intracellular targeting and tubule assembly of Grapevine fanleaf virus movement protein in tobacco BY-2 cells. Plant Cell, 15:2058-2075.

Latijnhouwers, M., Hawes, C., Carvalho, C., Oparka, K., Gillingham, A.K. y Boevink, P. (2005) An Arabidopsis GRIP domain protein locates to the trans-Golgi and binds the small GTPase ARL1. Plant J., 44:459-470.

Lawrence, M. y Jackson, A. O. (2001) Interactions of the TGB1 Protein during Cell-to-Cell Movement of Barley Stripe Mosaic Virus. J. Virol., 75:8712-8723.

Lazarowitz, S.G. y Beachy, R.N. (1999) Viral movement proteins as probes for intracellular and intercellular trafficking in plants. Plant Cell, 11:535-548. 
Lee, J.Y., Taoka, K., Yoo, B.C., Ben-Nissan, G., Kim, D.J. y Lucas, W.J. (2005) Plasmodesmalassociated protein kinase in tobacco and Arabidopsis recognizes a subset of non-cellautonomous proteins. Plant Cell, 17:2817-2831.

Leisner, S.M., Turgeon, R. y Howell, S.H. (1992) Long-distance movement of Cauliflower mosaic virus in infected Turnip plants. Mol Plant-Microbe In., 5:41-47.

Li, Y.I., Cheng, Y.M., Huang, Y.L., Tsai, C.H., Hsu, Y.H. y Meng, M.H. (1998) Identification acid characterization of the Escherichia coli-expressed RNA-dependent RNA polymerase of bamboo mosaic virus. J Virol., 72:10093-10099.

Li, J., Jia, D. y Chen, X. (2001) HUA1, a regulator of stamen and carpel identities in Arabidopsis, codes for a nuclear RNA binding protein. Plant Cell. 13:2269-2281.

Li, W.Z., Qu, F. y Morris, T.J. (1998) Cell-to-cell movement of turnip crinkle virus is controlled by two small open reading frames that function in trans.Virology, 244:405-416.

Li, W.M. y Wong, S.M. (2006) Analyses of subgenomic promoters of hibiscus chlorotic ringspot virus and demonstration of 5 ' untranslated region and 3 '-terminal sequences functioning as subgenomic promoters. J Virol., 80:3395-3405.

Lin, B. y Heaton, L. A. (2001) An Arabidpsis thaliana protein interacts with a movement protein of Turnip crinkle virus in yeast cells and in vitro. J. Gen. Virol., 82:1245-1251.

Lin, K., Simossis V.A., Taylor W.R. y Heringa J. (2005) A Simple and Fast Secondary Structure Prediction Algorithm using Hidden Neural Networks. Bioinformatics, 21:152-159.

Liu. J.Z., Blancaflor, E.B. y Nelson, R.S. (2005) The tobacco mosaic virus 126-kilodalton protein, a constituent of the virus replication complex, alone or within the complex aligns with and traffics along microfilaments. Plant Physiol., 138:1853-1865.

Liu, H., Boulton, M. I. y Davies, J. W. (1997) Maize streak virus coat protein binds single- and double-stranded DNA in vitro. J Gen Virol., 78:1265-1270.

Liu, H., Boulton, M. I., Thomas, C. L., Prior, D. A., Oparka, K. J. y Davies, J. W. (1999) Maize streak virus coat protein is karyophyllic and facilitates nuclear transport of viral DNA. Mol Plant-Microbe In., 12:894-900.

Liu, Y., Lee, S. y Lee, F. S. (2006) Arl1p is involved in transport of the GPI-anchored protein Gas1p from the late Golgi to the plasma membrane. J. Cell Sci., 119:3845-3855.

Lough, T.J., Emerson, S.J., Lucas, W.J. y Forster, R.L. (2001) Trans-complementation of longdistance movement of White clover mosaic virus triple gene block (TGB) mutants: phloem-associated movement of TGBp1. Virology, 288:18-28.

Lu, C. y Fedoroff, N. (2000) A mutation in the Arabidopsis HYL1 gene encoding a dsRNA binding protein affects responses to abscisic acid, auxin, and cytokinin. Plant Cell, 12:2351-2366.

Lu, R., Folimonov, A., Shintaku, M., Li, W.X., Falk, B.W., Dawson, W.O. y Ding, S.W. (2004) Three distinct suppressors of RNA silencing encoded by a 20-kb viral RNA genome. Proc Natl Acad Sci U S A., 101:15742-15747. 
Lucas, W.J. (2006) Plant viral movement proteins: Agents for cell-to-cell trafficking of viral genomes. Virology, 344:169-184.

Lucas, W.J., Bouché-Pillon, S, Jackson, D.P., Nguyen. L., Baker, L., Ding, B. y Hake, S. (1995) Selective trafficking of KNOTTED1 homeodomain protein and its mRNA through plasmodesmata. Science, 270:1980-1983.

Lucas, W.J. y Lee, J.Y. (2004) Plant cell biology - Plasmodesmata as a supracellular control network in plants. Nature Reviews Mol Cell Biol., 5:712-726.

Luís-Arteaga, M. (1986) Virosis de Cucurbitáceas. I Jornadas Nacionales de Cultivos Protegidos. Almería 14-17 mayo. 20pp.

Luís-Arteaga, M. (1994) Enfermedades producidas por virus. En: Enfermedades de las cucurbitáceas en España. Monografías de la sociedad española de Fitopatología n¹, Agropubli (Phytoma-España), 73-93.

Ma, B., Elkayam, T., Wolfson, H. y Nussinov, R. (2003) Protein-protein interactions: structurally conserved residues distinguish between binding sites and exposed protein surfaces. Proc. Natl. Acad. Sci. U S A., 100:5772-5777.

Mahajan, S., Dolja, V.V. y Carrington, J.C. (1996) Roles of the sequence encoding tobacco etch virus capsid protein in genome amplification: Requirements for the translation process and a cis-active element. J Virol., 70:4370-4379.

Malamy, J., Carr, J.P., Klessig, D.F. y Raskin, I. (1990) Salicylic Acid: A Likely Endogenous Signal in the Resistance Response of Tobacco to Viral Infection. Science, 250:1002-1004.

Malik, P.S., Kumar, V., Bagewadi, B. y Mukherjee, S.K. (2005) Interaction between coat protein and replication initiation protein of Mung bean yellow mosaic India virus might lead to control of viral DNA replication. Virology, 337:273-283.

Marcos, J.F., Vilar, M., Perez-Paya, E. y Pallas, V. (1999) In vivo detection, RNA-binding properties and characterization of the RNA-binding domain of the $p 7$ putative movement protein from carnation mottle carmovirus (CarMV). Virology, 255:354-365.

Martínez-Gil L., Saurí A., Vilar M., Pallás V. y Mingarro I. (2007) Membrane insertion and topology of the p7B movement protein of Melon Necrotic Spot Virus (MNSV). Virology, 367:348-357.

Mas, P. y Beachy, R.N. (1999) Replication of tobacco mosaic virus on endoplasmic reticulum and role of the cytoskeleton and virus movement protein in intracellular distribution of viral RNA. J Cell Biol., 147:945-958.

Mas, P. y Beachy, R.N. (2000) Role of microtubules in the intracellular distribution of tobacco mosaic virus movement protein. Proc Natl Acad Sci USA., 97:12345-12349.

Mas, P. y Pallas, V. (1995) Non-isotopic tissue printing hybridization: a new technique to study long distance plant virus movement. J Virol Meth., 52:317-326.

Mas, P. y Pallas, V. (1996) Long-distance movement of cherry leaf roll virus in infected tobacco plants. J Gen Virol., 77:531-40. 
Mas, P., Sanchez-Pina, M.A., Balsalobre, J.M. y Pallás, V. (2000) Subcellular localisation of cherry leaf roll virus coat genomic RNAs in tobacco leaves. Plant Sci., 153:113-124.

Matanis, T., Akhmanova, A., Wulf, P., Del Nery, E., Weide, T., Stepanova, T., Galjart, N., Grosveld, F., Goud, B., De Zeeuw, C.I., Barnekow, A. y Hoogenraad, C.C. (2002) Bicaudal-D regulates COPI-independent Golgi-ER transport by recruiting the dyneindynactin motor complex. Nat Cell Biol., 4:986-992.

Matheson, L.A., Hanton, S.L. y Brandizzi, F. (2006) Traffic between the plant endoplasmic reticulum and Golgi apparatus: to the Golgi and beyond. Curr Opin Plant Biol., 9:601-609.

McLean, B.G., Zupan, J. y Zambryski, P.C. (1995) Tobacco mosaic virus movement protein associates with the cytoskeleton in tobacco cells. Plant Cell, 7:2101-2114.

McLean, M.A., Campbell, R.N., Hamilton, R.I. y Rochon, D.M. (1994) Involvement of the Cucumber necrosis virus coat protein in the specificity of fungus transmission by Olpidium bornovanus. Virology, 204:840-842.

Melcher, U. (1990) Similarities between putative transport proteins of plant viruses. J Gen Virol., 71:1009-1018.

Melcher, U. (2000) The '30K' superfamily of viral movement proteins. J Gen Virol., 81:257-266.

Meng C, Chen J, Peng y JWong SM. (2006) Host-induced avirulence of hibiscus chlorotic ringspot virus mutants correlates with reduced gene-silencing suppression activity. J Gen Virol., 87:451-459.

Min-Huei, C. y Citrovsky, V. (2003) Systemic movement of a tobamovirus requires host cell pectin methylesterase. The Plant Journal, 35:386-392.

Mitra, R., Krishnamurthy, K., Blancaflor, E., Payton, M., Nelson, R.S. y Verchot-Lubicz, J. (2003) The Potato virus $X$ TGBp2 protein association with the endoplasmic reticulum plays a role in but is not sufficient for viral cell-to-cell movement. Virology, 312:35-48.

Mlotshwa, S., Voinnet, O., Mette, M.F., Matzke, M., Vaucheret, H., Ding. S,W., Pruss,G. y Vance, V.B. (2002) RNA silencing and the mobile silencing signal. Plant Cell, 14:289-301.

Moissiard, G. y Voinnet, O. (2004) Viral suppression of RNA silencing in plants. Mol Plant Pathol., 5:71-82.

Morales, M., Orjeda, G., Nieto, C., Leeuwen, H.V., Monfort, A., Charpentier, M., Caboche, M., Arus, P., Puigdomenech, P., Aranda, M.A., Dogimont, C., Bendahmane, A., y Garcia-Mas, J. (2005) A physical map covering the nsv locus that confers resistance to Melon necrotic spot virus in melon (Cucumis melo L.). Theor Appl Genet., 29:1-9.

Moreau, P., Brandizzi, F., Hanton, S., Chatre, L., Melser, S., Hawes, C. y Satiat-Jeunemaitre, B. (2007) The plant ER-Golgi interface: a highly structured and dynamic membrane complex. J Exp Bot., 58:49-64.

Moreno, I.M., Thompson, J.R. y García-Arenal, F. (2004) Analysis of the systemic colonization of cucumber plants by Cucumber green mottle mosaic virus. J Gen Virol., 85:749-759. 
Morozov, S.Y., Ryabov, E.V., Leiser, R.M. y Zavriev, S.K. (1995) Use of highly conserved motifs in plant-virus RNA-polymerases as the tags for specific detection of carmovirus-related RNA-dependent RNA-polymerase genes. Virology, 207:312-315.

Morozov, S.Y. y Solovyev, A.G. (2003) Triple gene block: modular design of a multifunctional machine for plant virus movement. J Gen Virol., 84:1351-1366.

Muench, D.G. y Mullen, R.T. (2003) Peroxisome dynamics in plant cells: a role for the cytoskeleton. Plant Sci., 164:307-315.

Nagy, P.D., Pogany, J. y Simon, A.E. (1999) RNA elements required for RNA recombination function as replication enhancers in vitro and in vivo in a plus-strand RNA virus. EMBO J., 18:5653-5665.

Nagy, P.D., Pogany, J. y Simon, A.E. (2001) In vivo and in vitro characterization of an RNA replication enhancer in a satellite RNA associated with turnip crinkle virus. Virology, 288:315-324.

Nagy, P.D. y Simon, A.E. (1998a) In vitro characterization of late steps of RNA recombination in turnip crinkle virus - I. Role of the motif1-hairpin structure. Virology, 249:379-392.

Nagy, P.D. y Simon, A.E. (1998b) In vitro characterization of late steps of RNA recombination in turnip crinkle virus - II. The role of the priming stem and flanking sequences. Virology, 249:393-405.

Navarro, J.A., Botella, F., Maruhenda, A., Sastre, P., Sánchez-Pina, M.A. y Pallas, V. (2004) Comparative infection progress analysis of Lettuce big-vein virus and Mirafiori lettuce virus in lettuce crops by developed molecular diagnosis techniques. Phytopathology, 94:470-477.

Navarro, J. A., Genoves, A., Climent, J., Sauri, A., Martinez-Gil, L., Mingarro, I. y Pallas, V. (2006) RNA-binding properties and membrane insertion of Melon necrotic spot virus (MNSV) double gene block movement proteins. Virology, 356:57-67.

Nebenführ, A., Gallagher, L.A., Dunahay, T.G., Frohlick, J.A., Mazurkiewicz, A.M., Meehl, J.B. y Staehelin, L.A. (1999) Stop-and-go movements of plant Golgi stacks are mediated by the acto-myosin system. Plant Physiol., 121:1127-1142.

Nebenführ, A., Ritzenthaler, C. y Robinson, D.G. (2002) Brefeldin A: Deciphering an enigmatic inhibitor of secretion. Plant Physiol., 130:1102-1108.

Nelson, R.S. y Citovsky, V. (2005) Plant viruses. Invaders of cells and pirates of cellular pathways. Plant Physiol., 138:1809-1814.

Nelson, R. S. y van Bel, A.J.E. (1998) The mystery of virus trafficking into, through and out of the vascular tissue. Progress in botany, 59:476-533.

Neumann, U., Brandizzi, F. y Hawes, C. (2003) Protein transport in plant cells: In and out of the Golgi. Ann Botany., 92:167-180.

Nilsson, I. y von Heijne, G. (1993) Determination of the distance between the oligosaccharyltransferase active site and the endoplasmic reticulum membrane. $\mathrm{J} \mathrm{Biol}$ Chem., 268:5798-5801. 
Noueiry, A. O., Lucas, W. J. y Gilbertson, R. L. (1994) Two proteins of a plant DNA virus coordinate nuclear and plasmodesmal transport. Cell, 76:925-932.

Ohshima, K., Ando, T., Motomura, N., Matsuo, K. y Sako, N. (2000) Comparative study on genomes of two Japanese melon necrotic spot virus isolates. Acta Virol., 44:309-314.

Omarov, R.T., Qi, D. y Scholthof, K.B.G. (2005) The capsid protein of satellite Panicum mosaic virus contributes to systemic invasion and interacts with its helper virus. $J$ Virol., 79:97569764.

Oostergetel, G.T., Mellema, J.E. y Cusack, S. (1983) Solution scattering study on the structure of alfalfa mosaic virus strain VRU. J. Mol Biol., 171:157-173.

Oparka, K.J., Prior, D.A.M., SantaCruz, S., Padgett, H.S. y Beachy, R.N. (1997) Gating of epidermal plasmodesmata is restricted to the leading edge of expanding infection sites of tobacco mosaic virus (TMV). Plant J., 12:781-789.

Oparka, K.J. y Turgeon, R. (1999) Sieve elements and companion cells - Traffic control centers of the phloem. Plant Cell, 11:739-750.

Osborne, J. C. y Elliot, R. M. (2000) RNA binding properties of Bunyamwera virus nucleocapsid protein and selective binding to an element in the $5^{\prime}$ terminus of the negative-sense $S$ segment. J. Virol., 74:9946-9952.

Overall, R.L. (1999) Structure of plasmodesmata. In Plasmodesmata, Structure, Function, Role in Cell Comunication, A.J. van Bel and W.J.P. van Kestern, eds (Heidelberg, Germany: Spring-Verlag), pp. 129-148.

Owens, R.A., Blackburn, M. y Ding, B. (2001) Possible involvement of the phloem lectin in longdistance viroid movement. Mol Plant-Microbe In., 14:905-909.

Pallas, V. (2007) En el límite de la vida. Ed. La Voz de Galicia S.A. pp 9-124.

Pallas, V., Mas, P. y Sanchez-Navarro, J.A. (1998a) Detection of plant RNA viruses by nonisotopic dot-blot hybridization. En: Plant virus protocols : from virus isolation to transgenic resistance. Ed. Foster G and Taylor S. Humana Press, Totowa, 461-468.

Pallas, V., Sanchez-Navarro, J. A. y Diez, J. (1999) In vitro evidence for RNA binding properties of the coat protein of prunus necrotic ringspot ilarvirus and their comparison to related and unrelated viruses. Arch Virol., 144:797-803.

Pallás, V., Sánchez-Navarro, J. A., Más, P., Cañizares, M. C., Aparicio, F. y Marcos, J. F. (1998b) Molecular diagnostic techniques and their potential role in stone fruit certification schemes. Options Méditerr. 19:191-208. Heinlein, M

Panavas, T., Hawkins, C.M., Panaviene, Z. y Nagy, P.D. (2005) The role of the p33:p33/p92 interaction domain in RNA replication and intracellular localization of p33 and p92 proteins of Cucumber necrosis tombusvirus. Virology, 338:81-95.

Panavas, T., Pogany, J. y Nagy, P.D. (2002a) Analysis of minimal promoter sequences for plusstrand synthesis by the Cucumber necrosis virus RNA-dependent RNA polymerase. Virology, 296:263-274. 
Panavas, T., Pogany, J. y Nagy, P.D. (2002b) Internal initiation by the cucumber necrosis virus RNA-dependent RNA polymerase is facilitated by promoter-like sequences. Virology, 296:275-287.

Panavas, T., Stork, J. y Nagy, P.D. (2006) Use of double-stranded RNA templates by the tombusvirus replicase in vitro: Implications for the mechanism of plus-strand initiation. Virology, 352:110-120.

Panaviené, Z., Baker, J.M. y Nagy, P.D. (2003) The overlapping RNA-binding domains of p33 and p92 replicase proteins are essential for tombusvirus replication. Virology, 308:191205.

Panic, B., Perisic, O., Veprintsev, D.B., Williams, R.L. y Munro, S. (2003b) Structural basis for Arl1-dependent targeting of homodimeric GRIP domains to the Golgi apparatus. Mol Cell., 12:863-874.

Panic, B., Whyte, J.R. y Munro, S. (2003a) The ARF-like GTPases Arl1p and Arl3p act in a pathway that interacts with vesicle-tethering factors at the Golgi apparatus. Curr Biol., 13:405-410.

Pata, J. D., Schultz, S. C. y Kirkegaard, K. (1995) Functional oligomerization of poliovirus RNAdependent RNA polymerase. RNA, 1:466-477.

Patrick, J.M. (1991) Control of phoem transport to and short-distance transfer in sink regions: an overview. En "Recent advances in phloem transport and assimilate compartmentation". Editado por Bonnemain, J.L., Delrot, S., Lucas, W.J. y Dainty, J. Quest editions, Nanates, France, 167-177.

Peremyslov, V.V., Pan, Y.W. y Dolja V.V. (2004) Movement protein of a closterovirus is a type III integral transmembrane protein localized to the endoplasmic reticulum. J Virol., 78:3704-3709.

Petersen, B.O. y Albrechtsen, M. (2005) Evidence implying only unprimed RdRP activity during transitive gene silencing in plants. Plant Mol Biol., 58:575-583.

Pfeffer, S.R. (2001) Rab GTPases: specifying and deciphering organelle identity and function. Trends Cell Biol., 11:487-91.

Pfeffer, S. (2003) Membrane domains in the secretory and endocytic pathways. Cell, 112:507517.

Phillipson, B.A., Pimpl, P., daSilva, L.L., Crofts, A.J., Taylor, J.P., Movafeghi, A., Robinson, D.G. y Denecke, J. (2001) Secretory bulk flow of soluble proteins is efficient and COPII dependent. Plant Cell, 13:2005-2020.

Pimpl, P., Hanton, S.L., Taylor, J.P., Pinto-daSilva, L.L. y Denecke, J. (2003) The GTPase ARF1p controls the sequence-specific vacuolar sorting route to the lytic vacuole. Plant Cell, 15:1242-1256.

Pogany, J., White, K.A. y Nagy, P.D. (2005) Specific binding of tombusvirus replication protein p33 to an internal replication element in the viral RNA is essential for replication. $J$ Virol., 79:4859-4869. 
Pouwels. J., Van Der Krogt, G.N.M., Van Lent, J., Bisseling, T. y Wellink, J. (2002) The cytoskeleton and the secretory pathway are not involved in targeting the cowpea mosaic virus movement protein to the cell periphery. Virology, 297:48-56.

Pouwels, J., van der Velden, T., Willemse, J., Borst, J.W., van Lent, J., Bisseling, T. y Wellink, J. (2004) Studies on the origin and structure of tubules made by the movement protein of Cowpea mosaic virus. J Gen Virol., 85:3787-3796.

Prokhnevsky, A.I., Peremyslov, V.V. y Dolja, V.V. (2005) Actin cytoskeleton is involved in targeting of a viral Hsp70 homolog to the cell periphery. J Virol., 79:14421-14428.

Prokhnevsky, A.I., Peremyslov, V.V., Napuli, A.J. y Dolja, V.V. (2002) Interaction between longdistance transport factor and Hsp70-related movement protein of Beet yellows virus. $J$ Virol., 76:11003-11011.

Qiut, W.P. y Scholthof, H.B. (2001) Effects of inactivation of the coat protein and movement genes of Tomato bushy stunt virus on early accumulation of genomic and subgenomic RNAs. J Gen Virol., 82:3107-3114.

Qu, F. y Morris, T.J. (2000) Cap-independent translational enhancement of turnip crinkle virus genomic and subgenomic RNAs. J Virol., 74:1085-1093.

Qu, F. y Morris, T.J. (2005) Suppressors of RNA silencing encoded by plant viruses and their role in viral infections. FEBS Lett., 579:5958-5964.

Qu, F., Ren, T. y Morris, T.J. (2003) The coat protein of turnip crinkle virus suppresses posttranscriptional gene silencing at an early initiation step. $J$ Virol., 77:511-522.

Rajamani, D., Thiel, S., Bajad, S. y Camacho, C. J. (2004) Anchor residues in protein-protein interactions. Proc. Natl. Acad. Sci. U S A., 101:11287-11292.

Rajendran, K.S. y Nagy P.D. (2003) Characterization of the RNA-binding domains in the replicase proteins of Tomato bushy stunt virus. J Virol., 77:9244-9258.

Rajendran, K.S. y Nagy P.D. (2004) Interaction between the replicase proteins of Tomato bushy stunt virus in vitro and in vivo. Virology, 326:250-261.

Rajendran, K.S., Pogany, J. y Nagy, P.D. (2002) Comparison of Turnip crinkle virus RNAdependent RNA polymerase preparations expressed in Escherichia coli or derived from infected plants. J Virol., 76:1707-1717.

Rao, A.L.N. y Cooper, B. (2006) Capsid protein gene and the type of host plant differentially modulate cell-to-cell movement of cowpea chlorotic mottle virus. Virus Genes, 32:219-227.

Rao, A.L.N. y Grantham, G.L. (1996) Molecular studies on bromovirus capsid protein .2. Functional analysis of the amino-terminal arginine-rich motif and its role in encapsidation, movement, and pathology. Virology, 226:294-305.

Rapp, M., Granseth, E., Seppällä, S., y von Heijne, G. (2006) Identification and evolution of dual-topology membrane proteins. Nat. Struct. Mol. Biol., 13:112-116.

Reichel, C. y Beachy, R.N. (1998) Tobacco mosaic virus infection induces severe morphological changes of the endoplasmic reticulum. Proc Natl Acad Sci USA., 95:11169-11174. 
Reichel, C. y Beachy, R.N. (2000) Degradation of Tobacco mosaic virus movement protein by the $26 \mathrm{~S}$ proteasome. J. Virol., 74:3330-3337.

Requena, A., Simon-Buela, L., Salcedo, G. y Garcia-Arenal, F. (2006) Potential involvement of a cucumber homolog of phloem protein 1 in the long-distance movement of Cucumber mosaic virus particles. Mol Plant-Microbe In., 19:734-746.

Rico, P., Ivars, P., Elena, S.F. y Hernandez, C. (2006) Insights into the selective pressures restricting Pelargonium flower break virus genome variability: Evidence for host adaptation. J Virol., 80:8124-8132.

Ritzenthaler, C. y Hofman, C. (2007) Tubule guide movement of plant viruses. In: Viral Transport in Plants (Waigmann, E. and Heinlein, M., eds.). Springer-Verlag Berlin Heidelberg, pp. 63-83.

Ritzenthaler, C., Nebenfuhr, A., Movafeghi, A., Stussi-Garaud, C., Behnia, L., Pimpl, P., Staehelin, L.A. y Robinson, D.G. (2002) Reevaluation of the effects of brefeldin A on plant cells using tobacco bright yellow 2 cells expressing Golgi-targeted green fluorescent protein and COPI antisera. Plant Cell, 14:237-261.

Riviere, C.J., Pot, J., Tremaine, J.H. y Rochon, D.M. (1989) Coat protein of Melon necrotic spot carmovirus is more similar to those of tombusviruses than those of carmoviruses. J Gen Virol., 70:3033-3042.

Riviere, C.J. y Rochon, D.M. (1990) Nucleotide-Sequence and Genomic Organization of Melon Necrotic Spot Virus. J Gen Virol., 71:1887-1896.

Robbins, M.A., Reade, R.D. y Rochon, D.M. (1997) A Cucumber necrosis virus variant deficient in fungal transmissibility contains an altered coat protein shell domain. Virology, 234:138146.

Roberts, I.M., Boevink, P., Roberts, A.G., Sauer, N., Reichel, C. y Oparka, K.J. (2001) Dynamic changes in the frequency and architecture of plasmodesmata during the sink-source transition in tobacco leaves. Protoplasma, 218:31-44.

Roberts, A.G., Cruz, S.S., Roberts, I.M., Prior, D.A.M., Turgeon, R. and Oparka, K.J. (1997) Phloem unloading in sink leaves of Nicotiana benthamiana: Comparison of a fluorescent solute with a fluorescent virus. Plant Cell, 9:1381-1396.

Robinson, D.G., Herranz, M.C., Bubeck, J., Pepperkok, R. y Ritzenthaler, C. (2007) Membrane dynamics in the early secretory pathway. Crit Rev Plant Sci., 26:199-225.

Rochon, D.M. y Tremaine, J.H. (1989) Complete nucleotide sequence of the Cucumber necrosis virus genome. Virology, 169:251-259.

Rojas, M. R., Noueiry, A. O., Lucas, W. J. y Gilbertson, R. L.(1998) Bean dwarf mosaic geminivirus movement proteins recognize DNA in a form- and size-specific manner. Cell, 95:105-113

Roth, B.M., Pruss, G.J. y Vance, V.B. (2004) Plant viral suppressors of RNA silencing. Virus Res., 102:97-108. 
Ruiz, M.T., Voinnet, O. y Baulcombe, D.C. (1998) Initiation and maintenance of virus-induced gene silencing. Plant Cell, 10:937-946.

Ryabov, E.V., Kim, S.H. y Taliansky, M. (2004a) Identification of a nuclear localization signal and nuclear export signal of the umbraviral long-distance RNA movement protein. J Gen Virol., 85:1329-1333.

Ryabov, E.V., Robinson, D.J. y Taliansky, M.E. (1999) A plant virus-encoded protein facilitates long-distance movement of heterologous viral RNA. Proc Natl Acad Sci USA., 96:12121217.

Ryabov, E.V., van Wezel, R., Walsh, J. y Hong, Y. (2004b) Cell-to-Cell, but not long-distance, spread of RNA silencing that is induced in individual epidermal cells. $J$ Virol., 78:31493154.

Sacher, R. y Ahlquist, P. (1989) Effects of deletions in the N-terminal basic arm of brome mosaic virus coat protein on RNA packaging and systemic infection. $J$ Virol., 63:45454552.

Sagi, G., Katz, A., Guenoune-Gelbart, D. y Epel, B.L. (2005) Class 1 reversibly glycosylated polypeptides are plasmodesmal-associated proteins delivered to plasmodesmata via the Golgi apparatus. Plant Cell, 17:1788-1800.

Saint-Jore, C.M., Evins, J., Batoko, H., Brandizzi, F., Moore, I. y Hawes, C. (2002) Redistribution of membrane proteins between the Golgi apparatus and endoplasmic reticulum in plants is reversible and not dependent on cytoskeletal networks. Plant J., 29:661-678.

Saint-Jore-Dupas, C., Gomord V. y Paris, N. (2004) Protein localization in the plant Golgi apparatus and the trans-Golgi network. Cell Mol Life Sci., 61:159-171.

Sambrok, J., Fritsch, E.F. y Maniatis, T. (1998) Molecular cloning: A laboratory Manual. (Cold Spring Harbor, NY: Cold Spring Harbor Press).

Sanchez-Navarro, J.A. y Bol, J.F. (2001) Role of the alfalfa mosaic virus movement protein and coat protein in virus transport. Mol Plant-Microbe In., 14:1051-1062.

Sanchez-Navarro, J.A., Herranz, M.C. y Pallas, V. (2006) Cell-to-cell movement of Alfalfa mosaic virus can be mediated by the movement proteins of llar-, bromo-, cucumo-, tobamo- and comoviruses and does not require virion formation. Virology, 346:66-73.

Sanchez-Navarro, J.A., Miglino, R., Ragozzino, A. y Bol, J.F. (2001). Engineering of Alfalfa mosaic virus RNA 3 into an expression vector. Arch. Virol., 146:923-939.

Sanderfoot, A. A., Ingham, D. J. y Lazarowitz, S. G. (1996) A viral movement protein as a nuclear shuttle. The geminivirus BR1 movement protein contains domains essential for interaction with BL1 and nuclear localization. Plant Physiol., 110:23-33.

Sareila, O., Hohkuri, M., Wahlroos, T. y Susi, P. (2004) Role of viral movement and coat proteins and RNA in phloem-dependent movement and phloem unloading of tobamoviruses. J Phytopathol., 152:622-629. 
Sauri, A., Saksena, S., Salgado, J., Johnson, A.E. y Mingarro, I. (2005) Double-spanning plant viral movement protein integration into the endoplasmic reticulum membrane is signal recognition particle-dependent, translocon-mediated, and concerted. J Biol Chem., 280:25907-25912.

Schaad, M.C., Jensen, P.E. y Carrington, J.C. (1997) Formation of plant RNA virus replication complexes on membranes: role of an endoplasmic reticulum-targeted viral protein. EMBO J., 16:4049-4059.

Scheer, C. y Groenewegen, J. (1971) Structure in cells of Vigna unguiculata infected with cowpea mosaic virus. Virology, 46:493-497.

Scheiffele, P. y Fullekrug, J. (2000) Glycosylation and protein transport. Essays Biochem., 36:27-35.

Schiender, I.R. (1965) Introdution, translocation and distribution of viruses in plants. Adv Virus. Res., 11:163-221

Scholthof, H.B. (2005) Plant virus transport: motions of functional equivalence. Trends Plant Sci., 10:376-382.

Seemanpillai, M., Elamawi, R., Ritzenthaler, C. y Heinlein, M. (2006) Challenging the role of microtubules in Tobacco mosaic virus movement by drug treatments is disputable. J Virol., 80:6712-6715.

Semancik, J.S., Conejero, V. and Gerhart, J. (1977) Citrus exocortis viroid: survey of protein synthesis in Xenopus laevis oocytes following addition of viroid RNA.Virology, 80:218-221.

Shirasu, K. y Schulze-Lefert, P. (2003) Complex formation, promiscuity and multi-functionality: protein interactions in disease-resistance pathways.Trends Plant Sci., 8:252-258.

Short, B., Haas, A. y Barr, F.A. (2005) Golgins and GTPases, giving identity and structure to the Golgi apparatus. Biochim Biophys Acta., 1744:383-95.

Short, B., Preisinger, C., Schaletzky, J., Kopajtich, R. y Barr, F.A. (2002) The Rab6 GTPase regulates recruitment of the dynactin complex to Golgi membranes. Curr Biol., 12:17921795.

Siegel, R.W., Adkins, S. y Kao, C.C. (1997) Sequence-specific recognition of a subgenomic RNA promoter by a viral RNA polymerase. Proc Natl Acad Sci USA., 94:11238-11243.

Silhavy, D., Molnár, A., Lucioli, A., Szittya, G., Hornyik, C., Tavazza, M. y Burgyán, J. (2002) A viral protein suppresses RNA silencing and binds silencing-generated, 21- to 25nucleotide double-stranded RNAs. EMBO J., 21:3070-3080.

Silva, A.M. y Rossmann, M.G. (1987) Refined structure of southern bean mosaic virus at 2.9 A resolution. J Mol Biol., 197:69-87.

Skuzeski J.M. y Morris T.J. (1995) Quantitative analysis of the binding of Turnip crinkle virus coat protein to RNA fails to demonstrate binding specificity but reveals a highly cooperative assembly interaction. Virology, 210:82-90. 
Stefano, G., Renna, L., Hanton, S. L., Chatre, L., Haas, T. A. y Brandizzi, F. (2006) ARL1 plays a role in the binding of the GRIP domain of a peripheral matrix protein to the Golgi apparatus in plant cells. Plant Mol Biol., 61:431-449.

Stopar, D., Spruijt, R. B. y Hemminga, M. A. (2006) Anchoring mechanisms of membraneassociated M13 major coat protein. Chem. Phys. Lipids., 141:83-93.

Solovyev, A.G., Stroganova, T.A.,, Zamyatnin, A.A., Fedorkin, O.N., Schiemann, J. y Morozov, S.Y. (2000) Subcellular sorting of small membrane-associated triple gene block proteins: TGBp3-assisted targeting of TGBp2. Virology, 269:113-127.

Solovyev, A.G., Zelenina, D.A., Savenkov, E.I., Grdzelishvili, V.Z., Morozov, S.Y., Lesemann, D.E., Maiss, E., Casper, R. y Atabekov, J.G. (1996) Movement of a barley stripe mosaic virus chimera with a tobacco mosaic virus movement protein. Virology, 217:435-441.

Solovyev, A.G., Zelenina, D.A., Savenkov, E.I., Grdzelishvili, V.Z., Morozov, S.Y., Maiss, E., Casper, R. y Atabekov, J.G. (1997) Host-controlled cell-to-cell movement of a hybrid barley stripe mosaic virus expressing a dianthovirus movement protein. Intervirology, 40:1-6

Sokolova, M., Prufer, D., Tacke, E. y Rohde, W. (1997) The potato leafroll virus 17K movement protein is phosphorylated by a membrane-associated protein kinase from potato with biochemical features of protein kinase C. FEBS Lett., 400:201-205.

Soto, M.J., Chen, L.F., Seo, Y.S. y Gilbertson, R.L. (2005) Identification of regions of the Beet mild curly top virus (family Geminiviridae) capsid protein involved in systemic infection, virion formation and leafhopper transmission. Virology, 341:257-270.

Stupina, V. y Simon, A.E. (1997) Analysis in vivo of turnip crinkle virus satellite RNA C variants with mutations in the 3'-terminal minus-strand promoter. Virology, 238:470-477.

Sun, X. y Simon, A.E. (2006) A cis-replication element functions in both orientations to enhance replication of Turnip crinkle virus. Virology, 352:39-51.

Taliansky, M.E. (2006) Identification of plant host factors interacting with viruses: Novel targets for virus control. En : Virus Diseases and Crop Biosecurity. Ed. Springer Netherlands. pp 101-106.

Taliansky, M.E. y Garcia-Arenal, F. (1995) Role of Cucumovirus Capsid Protein in LongDistance Movement Within the Infected-Plant. J Virol., 69:916-922.

Thomas, C.L., Leh, V., Lederer, C. y Maule, A. J. (2003) Turnip crinkle virus coat protein mediates suppression of RNA silencing in Nicotiana benthamiana. Virology, 306:33-41.

Thompson, J.D., Gibson, T.J., Plewniak, F., Jeanmougin, F. y Higgins, D.G. (1997) The ClustalX windows interface: flexible strategies for multiple sequence alignment aided by quality analysis tools. Nucleic Acids Res., 24:4876-4882.

Tomenius, K., Clapham, D. y Meshi, T. (1987) Localization by Immunogold Cytochemistry of the Virus-Coded 30K Protein in Plasmodesmata of Leaves Infected with Tobacco MosaicVirus. Virology, 160:363-371. 
Tomlinson, J.A. y Thomas, B.J. (1986). Studies on Melon Necrotic Spot Virus-Disease of Cucumber and on the Control of the Fungus Vector (Olpidium-Radicale). Ann App Biol., 108:71-80.

Treger, M. y Westhof, E. (2001) Stadistical análisis of atomic contacts at RNA-protein interfaces. J Mol Recognit., 14:199-214.

Tse, Y.C., Lo, S.W., Hillmer, S., Dupree, P. y Jiang, L. (2006) Dynamic response of prevacuolar compartments to brefeldin a in plant cells. Plant Physiol., 142:1442-1459.

Tusnady, G.E. y Simon, I. (1998) Principles governing amino acid composition of integral membrane proteins: application to topology prediction. J Mol Biol., 283:489-506.

van Geest, M. y Lolkema, J.S. (2000) Membrane topology and insertion of membrane proteins: search for topogenic signals. Microbiol. Mol. Biol. Rev., 64:13-33.

Vaquero, C., Liao, Y.C., Nähring, J. y Fischer, R. (1997) Mapping of the RNA-binding domain of the cucumber mosaic virus movement protein. J Gen Virol., 78:2095-1099.

Verchot-Lubicz J. (2005) A new cell-to-cell transport model for Potexviruses. Mol Plant-Microbe In., 18:283-290.

Vilar, M., Esteve, V., Pallas, V., Marcos, J.F. y Perez-Paya, E. (2001) Structural properties of carnation mottle virus p7 movement protein and its RNA-binding domain. J Biol Chem., 276:18122-18129.

Vilar, M., Sauri, A., Marcos, J.F., Mingarro, I. y Perez-Paya, E. (2005) Transient structural ordering of the RNA-binding domain of carnation mottle virus p7 movement protein modulates nucleic acid binding. Chembiochem., 6:1391-1396.

Vilar, M., Sauri, A., Monne, M., Marcos, J.F., von Heijne, G., Perez-Paya, E. Mingarro, I. (2002) Insertion and topology of a plant viral movement protein in the endoplasmic reticulum membrane. J Biol Chem., 277:23447-23452.

Voinnet, O. (2001) RNA silencing as a plant immune system against viruses. Trend Gen., 17:449-459.

Voinnet, O., Lederer, C. y Baulcombe, D.C. (2000) A viral movement protein prevents spread of the gene silencing signal in Nicotiana benthamiana. Cell, 103:157-167.

von Heijne, G. (1992) Membrane-protein structure prediction-hydrophobicity analysis and the positive-inside rule. J Mol Biol., 225:487-494.

von Heijne, G. (2006). Membrane-protein topology. Nat. Rev. Mol. Cell Biol., 7:909-918.

Wagner, C., Palacios, I., Jaeger, L., St Jonson. D., Ehresmann, B., Ehresmann, C. y Brunel, C. (2001) Dimerization of the 3'UTR of bicoid mRNA involves a two-step mechanism. J. Mol.Biol., 313:511-524.

Waigmann, E., Cohen, Y., McLean, G. y Zambryski, P. (1998) Plasmodesmata: gateways for information transfer. Symp Soc Exp Biol., 51:43-49.

Waigmann, E., Curin, M. y Heinlein, M. (2007) Tobacco mosaic virus-a model for macromolecular cell-to-cell spread. In: Viral Transport in Plants (Waigmann, E. and Heinlein, M., eds.). Springer-Verlag Berlin Heidelberg, pp. 29-62. 
Waigmann, E., Lucas, W.J., Citovsky, V. y Zambryski, P. (1994) Direct Functional Assay for Tobacco Mosaic-Virus Cell-To-Cell Movement Protein and Identification of A Domain Involved in Increasing Plasmodesmal Permeability. Proc Natl Acad Sci USA., 91:14331437.

Waigmann, E., Ueki, S., Trutnyeva, K. y Citovsky, V. (2004) The ins and outs of nondestructive cell-to-cell and systemic movement of plant viruses. Crit Rev Plant Sci. 23:195-250.

Waigmann, E. y Zambryski, P. (1994) Plasmodesmata - Gateways for Rapid InformationTransfer. Current Biology., 4:713-716.

Walter M, Chaban C, Schütze K, Batistic O, Weckermann K, Näke C, Blazevic D, Grefen C, Schumacher K, Oecking C, Harter K, y Kudla J. (2004) Visualization of protein interactions in living plant cells using bimolecular fluorescence complementation. Plant J., 40:428-38

Wang, M.B., Bian, X.Y., Wu, L.M., Liu, L.X., Smith, N.A., Isenegger, D, Wu, R.M., Masuta, C, Vance, V.B., Watson, J.M., Rezaian, A., Dennis, E.S. y Waterhouse, P.M. (2004) On the role of RNA silencing in the pathogenicity and evolution of viroids and viral satellites. Proc Natl Acad Sci U S A., 101:3275-80.

Wang, J.L. y Simon, A.E. (1997) Analysis of the two subgenomic RNA promoters for turnip crinkle virus in vivo and in vitro. Virology, 232:174-186.

Wang, J.L. y Simon, A.E. (1999) Symptom attenuation by a satellite RNA in vivo is dependent on reduced levels of virus coat protein. Virology, 259:234-245.

Wang, J.L. y Simon, A.E. (2000) 3 '-end stem-loops of the subviral RNAs associated with turnip crinkle virus are involved in symptom modulation and coat protein binding. $J$ Virol., 74:6528-6537.

Wang, H.H. y Wong, S.M. (2004) Significance of the 3'-terminal region in minus-strand RNA synthesis of Hibiscus chlorotic ringspot virus. J Gen Virol., 85:1763-1776.

Wee, E. G.-T., Sherrier, d. J., Prime, T. A. y Dupree, P. (1998) Targeting of active Sialyltransferase to the plant Golgi apparatus. Plant Cell, 10:1759-1768.

White, K.A. y Nagy, P.D. (2004) Advances in the molecular biology of tombusviruses: gene expression, genome replication, and recombination. Prog Nucleic Acid Res Mol Biol., 78:187-226.

White, K.A., Skuzeski, J.M., Li, W., Wei, N. y Morris, T.J. (1995) Immunodetection, expression strategy and complementation of Turnip crinkle virus p28 and p88 replication components. Virology, 211:525-534.

Wobbe, K.K., Akgoz, M., Dempsey, D.A. y Klessig, D.F. (1998) A single amino acid change in Turnip crinkle virus movement protein p8 affects RNA binding and virulence on Arabidopsis thaliana. J Virol. 72:6247-6250.

Wolf, S., Deom, C.M., Beachy, R.N. y Lucas, W.J. (1989) Movement Protein of Tobacco Mosaic-Virus Modifies Plasmodesmatal Size Exclusion Limit. Science, 246:377-379. 
Wright, K.M., Wood, N.T., Roberts, A.G., Chapman, S., Boevink, P., MacKenzie, K.M. y Oparka, K.J. (2007) Targeting of TMV movement protein to plasmodesmata requires the actin/ER network: Evidence from FRAP. Traffic, 8:21-31.

Wu, M., Lu, L., Hong, W. y Song, H. (2004) Structural basis for recruitment of GRIP domain golgin-245 by small GTPase Arl1. Nat Struct Mol Biol. 11:86-94.

Wung, C.H., Hsu, Y.H., Liou, D.Y., Huang, W.C., Lin, N.S. y Chang, B.Y. (1999) Identification of the RNA-binding sites of the triple gene block protein 1 of bamboo mosaic potexvirus. $J$ Gen Virol. 80:1119-1126.

Xie, Z.X., Fan, B.F., Chen, C.H. y Chen, Z.X. (2001) An important role of an inducible RNAdependent RNA polymerase in plant antiviral defense. Proc Natl Acad Sci USA. 98:65166521.

Yaegashi, H., Takahashi, T., Isogai, M., Kobori, T., Ohki, S. y Yoshikawa, N. (2007) Apple chlorotic leaf spot virus $50 \mathrm{kDa}$ movement protein acts as a suppressor of systemic silencing without interfering with local silencing in Nicotiana benthamiana. J Gen Virol. 88:316-324.

Yang, Y., Ding, B., Baulcombe, D.C. y Verchot, J. (2000) Cell-to-cell movement of the 25K protein of Potato virus $\mathrm{X}$ is regulated by three other viral proteins. Mol Plant-Microbe In. 13:599-605.

Yang, Y.D., Elamawi, R., Bubeck, J., Pepperkok, R., Ritzenthaler, C. y Robinsonm D.G. (2005) Dynamics of COPII vesicles and the Golgi apparatus in cultured Nicotiana tabacum BY-2 cells provides evidence for transient association of Golgi stacks with endoplasmic reticulum exit sites. Plant Cell. 17:1513-1531.

Yoshino, A., Bieler, B. M., Harper, D. C., Cowan, D. A., Sutterwala, S., Gay, D. M., Cole, N. B., McCaffery, J. M. y Marks, M. S. (2003) A role for GRIP domain proteins and/or their ligands in structure and function of the trans Golgi network. J. Cell Sci. 116:4441-4454.

Yoshioka, K., Matsushita, Y., Kasahara, M., Konagaya, K. y Nyunoya, H. (2004) Interaction of tomato mosaic virus movement protein with tobacco RIO kinase. Mol Cells. 17:223-229.

Yu, D.Q., Fan, B.F., MacFarlane, S.A. y Chen, Z.X. (2003) Analysis of the involvement of an inducible Arabidopsis RNA-dependent RNA polymerase in antiviral defense. Mol PlantMicrobe In. 16:206-216.

Zambryski, P. (1995) Plasmodesmata: plant channels for molecules on the move. Science, 270:1943-1944.

Zambrysky, P. y Crawford, K. (2000) Plasmodesmata: Gatekeepers for cell-to-cell transport of developmental signals in plants. Annu. Rev. Cell Dev. Biol., 16:393-417.

Zamyatnin Jr. A. A., Solovyev, A. G., Bozhkov, P. V., Valkonen, J. P. T., Morozov, S. Y. y Savenkov, E. I. (2006) Assessment of the integral membrane protein topology in living cells. Plant J. 46:145-154.

Zamyatnin, A.A., Solovyev, A.G., Sablina, A.A., Agranovsky, A.A., Katul, L., Vetten, H.J., Schiemann, J., Hinkkanen, A.E., Lehto, K. y Morozov, S.Y. (2002) Dual-colour imaging of 
membrane protein targeting directed by poa semilatent virus movement protein TGBp3 in plant and mammalian cells. J Gen Virol., 83:651-662.

Zamyatnin, A.A., Solovyev, A.G., Savenkov, E.I., Germundsson, A., Sandgren, M., Valkonen, J.P.T. y Morozov, S.Y. (2004) Transient coexpression of individual genes encoded by the triple gene block of Potato mop-top virus reveals requirements for TGBp1 trafficking. Mol Plant-Microbe In., 17:921-930.

Zerial, M. y McBride, H. (2001) Rab proteins as membrane organizers. Nat Rev Mol Cell Biol. 2:216. 